\title{
INTERDISCURSIVIDADE E PRÁTICAS COTIDIANAS: MODOS DE FAZER/OPERAR A POLITICA DE RESERVA DE VAGAS NA UERJ
}

Tese de Doutorado

Tese apresentada como requisito parcial para obtenção do grau de Doutor pelo Programa de Pós-Graduação em Psicologia Clínica do Departamento de Psicologia da PUC-Rio. Aprovada pela Comissão Examinadora abaixo assinada.

Orientador: Prof ${ }^{\mathrm{a}}$ Solange Jobim e Souza 


\section{INTERDISCURSIVIDADE E PRÁTICAS COTIDIANAS: MODOS DE FAZER/OPERAR A POLITICA DE RESERVA DE VAGAS NA UERJ}

Tese apresentada como requisito parcial para obtenção do grau de Doutor pelo Programa de Pós-Graduação em Psicologia Clínica do Departamento de Psicologia do Centro de Teologia e Ciências Humanas da PUC-Rio. Aprovada pela Comissão Examinadora abaixo assinada.

Prof ${ }^{a}$ Solange Jobim e Souza

Orientadora

Departamento de Psicologia PUC-Rio

Prof ${ }^{a}$ Esther Maria de Magalhães Arantes

Departamento de Psicologia PUC-Rio

Prof. Ronald João Jacques Arendt

Psicologia UERJ

Prof ${ }^{\mathrm{a}}$ Marcia Oliveira Moraes

Psicologia UFF

Prof. Marcelo Gustavo Andrade de Souza

Departamento de Educação PUC-Rio

Profa. Denise Berruezo Portinari

Coordenadora Setorial de Pós-Graduação

e Pesquisa do Centro de Teologia

e Ciências Humanas - PUC-Rio

Rio de Janeiro, 22 de agosto de 2012 
Todos os direitos reservados. É proibida a reprodução total ou parcial do trabalho sem autorização da universidade, da autora e do orientador.

\section{Luciana Ferreira Barcellos}

Graduou-se em psicologia na UERJ - Universidade do Estado do Rio de Janeiro -, em 2001. Especializou-se em Psicologia Jurídica na UERJ, em 2004. Concluiu o Mestrado pelo Programa de Pós-Graduação em Psicologia Clínica da PUC-Rio. Membro-colaboradora da Comissão de Ética do CRP-RJ por seis anos. Professora-substituta da Faculdade de Educação da UERJ, professora do curso de psicologia do IBMR - Instituto Brasileiro de Medicina e Reabilitação e do curso de psicologia do UBM - Centro Universitário de Barra Mansa.

Ficha Catalográfica

Barcellos, Luciana Ferreira

Interdiscursividade e práticas cotidianas: modos de fazer/operar a política de reserva de vagas na UERJ / Luciana Ferreira Barcellos ; orientador: Solange Jobim e Souza. - 2012.

261 f. : il. (color.) ; $30 \mathrm{~cm}$

Tese (doutorado) - Pontifícia Universidade Católica do Rio de Janeiro, Departamento de Psicologia, 2012.

Inclui bibliografia

1. Psicologia - Teses. 2. Interdiscursividade. 3. Práticas cotidianas. 4. Universidade. 5. Modos de subjetivação. $6 . \quad$ Contemporaneidade. 7. Ação afirmativa. I. Souza, Solange Jobim e. II. Pontifícia Universidade Católica do Rio de Janeiro. Departamento de Psicologia. III. Título. 
Em tudo o que escrevo, digo, sou, há um pouco de você.

Ao meu pai, Ronaldo (in memorian)

Por tudo.. 


\section{Agradecimentos}

A trajetória foi longa. Os entraves foram muitos. A chegada não teria sido possível sem os apoios e as torcidas.

A minha orientadora, Solange Jobim e Souza, por toda a aposta, incentivo, luta e parceria. Pelo enorme aprendizado, tanto no pensamento quanto na vida. Grande admiração, gratidão e respeito.

Ao GIPs - Grupo interdisciplinar de pesquisa da subjetividade (PPGP/PUC-Rio) Amigos no pensamento e na vida, Danilo e André. Cintia, Elis, Renata, Jessé, Denise, Carol, Djalma. Trocas fundamentais para consolidação deste trabalho.

Ao CNPq e à PUC-Rio, pelos auxílios concedidos.

Aos meus pais, Ronaldo e Cida. À minha mãe, exemplo de força e coragem, que faz acreditar que enquanto há vida, há sempre razão pra recomeçar.

À Ligia, minha irmã. Juntas sempre. Amiga e parceira de todas as jornadas. Apoio incondicional. A você e Marcus, meus agradecimentos pelas trocas e todo apoio.

As Tias Lourdes, Ana e Inez. Portos Seguros nos momentos de aflição. Agradeço o carinho e amizade de sempre.

Às amigas Débora, Suzana e Flávia. As boas recordações da época da infância inaciana. Seguindo o rastro do tempo que passa, renovamos sempre os laços de carinho que nos mantém perto umas das outras, apesar de tantas mudanças.

A Débora, pela amizade e parceria em todos os momentos.

À Danuza, pela parceria de tantos momentos.

Salve! Salve! Queridos amigos do Salve! Paola, ufa.. conseguimos! Fabiana e Paola, agradeço pela amizade e por todo o apoio. Gabriela Toledo, pelo carinho e amizade e pelo apoio técnico fundamental! Franciele, Juliana, Alessandra, Fernanda, Cynthia, queridas! Alexandre/bolinho, Omar, Fernando, Marquinho, Gustavo/But, Naruã, Guilherme, a todos do salve o meu carinho e gratidão. Presenças que tornam mais leves as agruras da vida!

As novas amigas e parceiras de estrada, Luana e Teresinha. Companhias queridas pela estrada rumo à Barra Mansa. Pelo apoio e parceria no trabalho e na vida.

Aos alunos... pedagogia/UERJ, psicologia/UBM, psicologia/IBMR. Pelo aprendizado da convivência e por tantas trocas enriquecedoras.

Aos sujeitos da pesquisa, pela gentileza de me emprestarem um pouco de suas experiências e histórias.

A Izabel Máximo. Pela aposta e apoio fundamental nesta reta final.

A Marcelina e Vera, pela paciência e prestatividade de sempre.

Ao professor Hildeberto Vireira Martins, pelas trocas profissionais tão valiosas, e pela amizade desde os tempos de UERJ.

Aos professores Márcia Moraes, Ronald Arendt, Esther Arantes, Marcelo Andrade, pela gentileza em participarem da banca de defesa e por todo o aprendizado proporcionado durante o percurso do Doutorado. 


\section{Resumo}

Barcellos, Luciana Ferreira; Jobim e Souza, Solange (orientadora). Interdiscursividade e práticas cotidianas: modos de fazer a política de reserva de vagas na UERJ. Rio de Janeiro, 2012. 261p. Tese de Doutorado - Programa de Pós-Graduação em Psicologia Clínica, Pontifícia Universidade Católica do Rio de Janeiro.

Este trabalho tem por objetivo investigar as práticas cotidianas a partir da implementação da política de reserva de vagas na UERJ. A política foi implementada nas universidades publicas brasileiras no conjunto mais amplo de ações afirmativas no ensino superior no Brasil, estando entre as pioneiras, a UNB (2002); UNEB (2003) e UERJ (2002). Os recortes contemplados pela política são vários, e os critérios de ingresso são estabelecidos de acordo com cada universidade, incluindo a autodeclaração, comissão de avaliação, fotografia, descendência, etc. A pesquisa pretendeu investigar as práticas cotidianas na UERJ a partir da política de reserva de vagas, que adota como recortes a raça e a condição socioeconômica, cujo critério de ingresso foi a autodeclaração. Estruturou-se uma política de assistência estudantil através do Proiniciar e da concessão de bolsa-permanência e do kit_cotista para custeio de gastos básicos para a formação do estudante ingressantes pela reserva de vagas. "A UERJ fala pelas paredes": este é modo de comunicação entre os sujeitos da UERJ que torna esta instituição peculiar. Sendo assim, proposta metodológica utiliza o registro de imagens-fotográficas de cartazes, informes, desenhos espalhados pelas paredes da universidade e a entrevista como etapa suprasequente, pondo em diálogo as imagens expostas na UERJ, o pesquisador e os sujeitos da pesquisa - grupos e/ou sujeitos ativos politicamente e participantes do cotidiano da instituição estudantes, cotistas e não-cotistas, funcionários, movimentos estudantis e representações dos cursos de graduação. Entende-se entrevista como um espaço de produção de sentidos e interdiscursividade como a possibilidade de trazer à tona a rede ideológica e de forças que compõem e atravessam as relações e experiências dos sujeitos da UERJ a partir da experiência da reserva de vagas.

\section{Palavras-chave}

Interdiscursividade; práticas cotidianas; universidade; modos de subjetivação; contemporaneidade; ação afirmativa. 


\section{Abstract}

Barcellos, Luciana Ferreira Barcellos; Jobim e Souza, Solange (Advisor). Interdiscussion and everyday practices: ways to develop/operate the policy for vacancies quota reservation at the State University of Rio de Janeiro (UERJ). Rio de Janeiro, 2012. 261p. Doctoral Thesis - Programa de Pós-Graduação em Psicologia Clínica, Pontifícia Universidade Católica do Rio de Janeiro.

The study aims to present the research conducted at UERJ in order to investigate the current experiences of subjects, from the advent of the policy for vacancies reservation in this institution (implemented since 2003). This institution is the pioneer in implementing the policy of vacancies quota reservation in the country. Although different criteria have been established via a quota system racial, public schools, among others - the triggering factor of greater polemic and controversy was the use of racial "cut-off". "UERJ talks though walls". The specificity of communication modes and transmission of information by the institution raised a methodology where the researcher was pointed toward the walls, murals, corridors and institutes surroundings. Traces of the signs left by the records of the subjects at the university are followed by the researcher during random walk (for six months 600 hundred images were photographically registered). The researcher, the research subjects and photographic images, interact at the time of interview, the same being understood as a space for the construction of meaning mediated by language. What the policy for vacancies quota reservation made exist at the university and everyday practices that were triggered by the experience? These and other questions guided the research and identified ways and thoughts, especially in the field of social psychology, sociocritical perspective. The authors Michel de Certeau, M. Bakhtin, F. Guattari and M. Foucault helped to reflect on the construction of subjectivity and everyday practices through the implementation of a policy of affirmative action, the themes for it triggered and the micropolitical effects of its consolidation in the scenario of Brazilian higher education.

\section{Keywords}

Affirmative Action; University; Cartography; Routine Practice; Subjectivity; Language. 


\section{Sumário}

1. Introdução

2. Contextualização histórico-política ...............................................................30

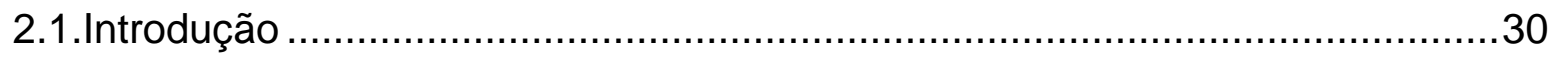

2.2. Democracia, Cidadania e Justiça Social: Reflexões Preliminares ..................32

2.3. Educação e Cidadania: Problemáticas Contemporâneas ................................39

2.4. Universidade - Gênese e Percursos.................................................... 47

2.5.Multiculturalismo e Educação: Pressupostos e Dilemas ................................52

2.6.Ações Afirmativas e Educação Superior no Brasil: Expansão e/ou

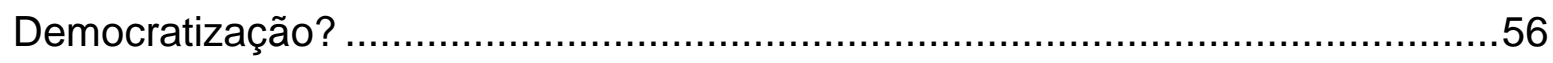

2.7. Os cursos pré-vestibulares comunitários e a PUC-Rio: A

experiência do Programa de Ação Social ........................................................62

2.8. Movimento Negro Brasileiro e Educação: Aspectos Históricos e

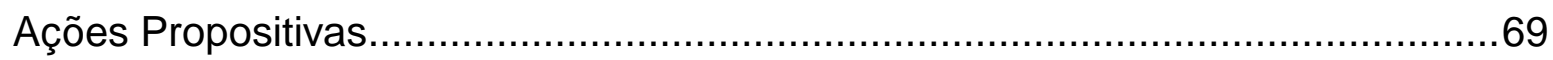

\section{A política de reserva de vagas nas universidades públicas}

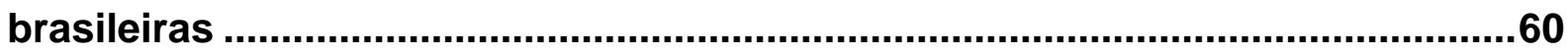

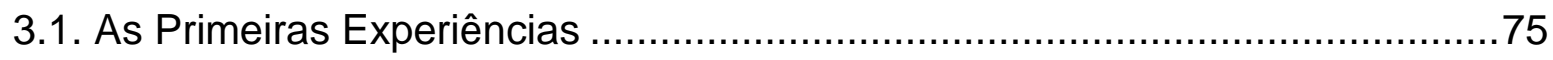

3.2. A UERJ e a Política de Reserva de Vagas: Histórico e Principais

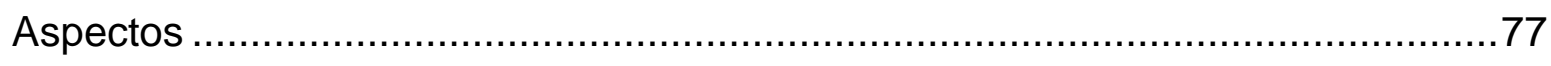

3.3. A Política de "cotas": Você é a favor ou contra? ...............................................

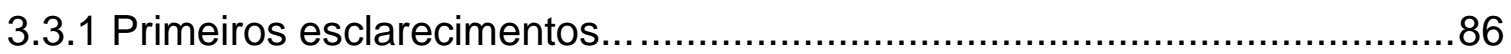

3.3.2 Constitucional ou inconstitucional? Controvérsias Jurídicas e o

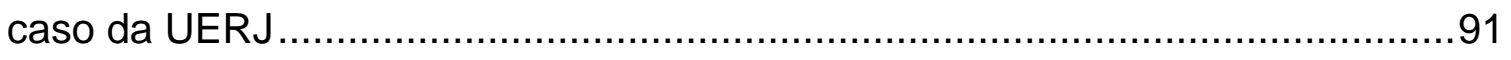

3.3.3 Cruzando o critério social com o critério racial ........................................97 
3.3.4 Proporcionalidade e razoabilidade: O caso da UNEB .85

3.3.5 As cotas raciais e o debate: Balanços preliminares a partir da política na UERJ 88

3.3.6 O critério "raça" e as tensões suscitadas: Os Casos da UNB e da UERJ .84

3.3.7 "Os olhos e filtros cognitivos da sociedade"? O híbrido ciênciapolítica: A antropologia e o caso da UnB .98

4.Metá-hódos em hódos-metá? No registro das peredes que guiam ................105

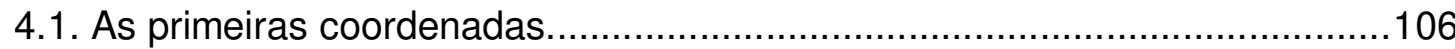

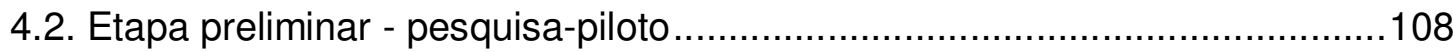

4.3. Em busca das ferramentas metodologicas ..............................................110

4.3.1. Re-conhecendo o território .............................................................110

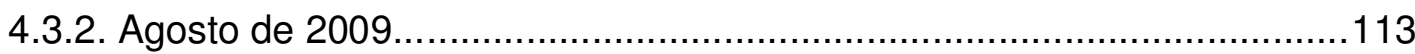

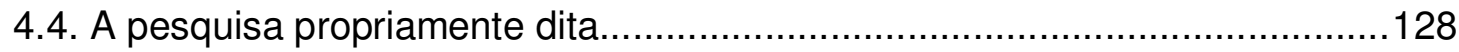

4.4.1. A linguagem fotográfica como recurso.............................................128

4.4.2. Os Fluxos e Relatos de um Itinerante-Fotógrafo .................................132

4.5. Segundo momento da pesquisa: a seleção das fotos................................147

4.6. Terceiro momento da pesquisa: a busca pelas entrevistas...........................149

4.7. É pessoal ou profissional? As intempéries de um andarilho-

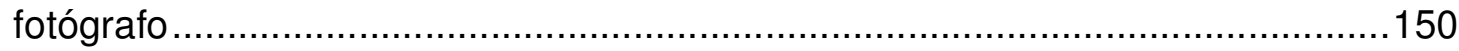

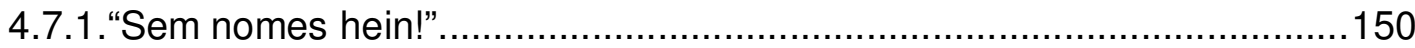

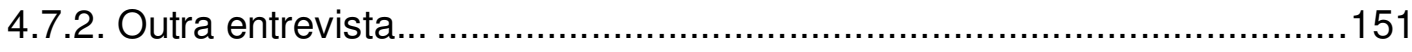

4.7.3."Essa não é a posição do Centro Acadêmico, mas a minha, pessoal." 
4.7.4. "Essas fotos são pra uso pessoal ou profissional?"

4.7.5. "Ah. Vou mostrar essa foto aqui, que é muito interessante!" 152

4.7.6. Entrevista sobre o tema das cotas? Você poderia conversar com

fulano que é especialista no assunto!" ou "não sei se te ajudei, não sou especialista no tema das cotas"

5.Modos de fazer/operar a politica de reserva de vagas na uerj: as práticas cotidianas nas vozes dos interlocutores.............................................153

5.1. A entrevista e a seleção das fotografias ..............................................154

5.2. A entrevista propriamente dita: as imagens-fotográficas entrevistam ...........159

5.3. O que a política de reserva de vagas fez fazer: As práticas cotidianas nas vozes dos interlocutores. 162

5.3.1. A Política de Assistência Estudantil e os Modos de Operar 162

5.3.2. O Debate sobre a Política de Cotas: Os Sujeitos da Pesquisa na Interface com As Imagens 179

5.3.3. A universidade na cidade e a cidade na universidade 214

5.3.4. Não-cotistas $\times$ Cotistas; Cotistas $\times$ cotistas, não-cotistas $\times$ nãocotistas: as uerjs e a pluralidade de experiências no convívio com a alteridade. 226

5.3.5. Os "jogos políticos" e a "Arena de Forças" .234

6. Considerações "finais" .243

7.Referências bibliográficas. .252 


\section{Lista de Figuras}

Foto 1 - Cartaz do Proiniciar 107

Foto 2 - Cartaz do Proiniciar 108

Foto 3 e 4 - UERJ 110

Foto 5 - Quadro de avisos/hall de entrada dos elevadores: PCB, PSTU,

Nova Democracia, MEPR. 114

Fotos 6 e 7 - Informativos de debates sobre as cotas na UERJ 115

Fotos 8 e 9 - Quadros de Avisos dos CAs de Direito e de Filosofia 116

Fotos 10,11 - Locais de circulação extra-oficiais com informes 116

Fotos 12 e 13 - Locais de circulação extra-oficiais com informes 117

Fotos 14 e 15 - hall do $5^{\circ}$ andar e entrada de uma secretaria de curso. A

primeira foto foi feita na descida da escada que chega ao $5^{\circ}$ andar. A

segunda imagem é da entrada da secretaria de um curso de graduação. 118

Fotos 16 e 17 - Centros Acadêmicos de ciências sociais e de história. $\quad 118$

Fotos 18 e 19 - Centro Acadêmico de Ciências Sociais e Centro

Acadêmico do curso de direito. $\quad 119$

Fotos 20, 21 - Centros Acadêmicos de Ciências Sociais e de Psicologia 120

Fotos 23, 24, 25 e 26 - Adesivos colados na entrada do Centro

Acadêmico de Serviço Social. $\quad 121$

Foto 27 - parede do hall do nono andar $\quad 123$

Foto 28 - Hall das salas de aula do nono andar 123

Foto 29 - Denegrir $\quad 125$

Foto 30 - Entrada do Diretório Central dos Estudantes. No vidro, um

cartaz do Proiniciar, com informações sobre renovação e documentação

referentes à bolsa dos estudantes "cotistas". 132

Foto 31 - Cartaz/Sintuperj $\quad 135$

Foto 32 (chapa 1): Ousar e Lutar/sintuperj $\quad 136$

Foto 33 (chapa 2): Resistência e Alternativa/sintuperj 136

Fotos 34 e 35 - CAEFALF - Fotos tiradas no hall das salas de aula, nono andar, referente ao processo eleitoral para gestão do centro acadêmico do curso de educação física.

Fotos 36 e 37 - Tiradas nas paredes da lanchonete onde se localiza a sala do centro acadêmico do curso de educação física. 
Fotos 38,39, 40 e 41 - CALC - Corredor das salas de aula do curso de direito

Fotos $42,43,44$ e 45 - CAPF - Corredor do $12^{\circ}$ andar - curso de pedagogia

Foto 46 - Mural do primeiro andar, entrada dos elevadores.

Foto 47 - tirada do quadro de partidos políticos no primeiro andar, entrada dos elevadores. A defesa do passe livre encontra-se em um jornal de campanha de determinado candidato.

Foto 48 - Corredor do curso de ciências sociais

Foto 49 - Hall do $9^{\circ}$ andar

Fotos 50, 51, 52 e 53. Estas imagens se encontravam em banners em exposição nos corredores da UERJ durante a semana de arte organizada pelos estudantes do curso de ciências sociais.

Fotos 54 e 55 - Entradas da UERJ (entrada principal e corredor de acesso ao metrô)

Foto 56 - Hall do segundo andar.

Foto 57 - Painel exibido no evento da "UERJ sem muros" por um grupo de pesquisa formado por estudantes da UERJ/Campus/São Gonçalo. O tema do trabalho é "Cotas na UERJ: Visualizando Territórios". Foto 58 - Primeiro andar/hall dos elevadores. Sintuperj - Sindicato dos Trabalhadores da UERJ, coordenador do curso pré-vestibular comunitário da instituição.

Foto 59 - Cartaz de uma escola da rede pública de ensino exposto no hall do terceiro andar da UERJ

Foto 60 - Auditório do primeiro andar/fundos.

Fotos 61 e 62 - Fotos expostas nas paredes do terceiro andar, durante um evento sobre infância e racismo. Os autores dos cartazes são alunos de escolas municipais, CIEPs, estudantes do segundo grau da Universidade. Foto 63 - "Proiniciar_banner: Orientações sobre manutenção da bolsa permanência"

Foto 64 "Eleições CALC_acúmulo de bolsas para cotistas" e Foto 65 "Banner_ DCE/gestão 'um novo enredo': Pelo Acúmulo de bolsas" respectivamente. 
Foto 66 - Kit_cotista ciências econômicas $\quad$ Foto 67 -

Kit_cotista direito 171

Foto 68 - "Eleições CAEFALF_distribuição do material dos cotistas" 159

Foto 69 - "O Grande Desafio": debate sobre cotas raciais. 166

Foto 70 - Debate sobre cotas na universidade $\quad 167$

Foto 71 - Cartaz: "Cotas Sociais e Raciais já: A universidade tem que reparar essa dívida".

Foto 72 - "VII Censo UERJ_política de reserva de vagas: qual o critério mais Justo?"

Foto - 73 - Censo UERJ - perfil estudante $\quad 180$

Foto 74 - "Denegrir_Mural no hall do 'queijo' 182

Foto - 75 - Jornal do CAFIL - Centro Acadêmico de Filosofia. 189

Fotos 76 e 77 - entrada do Denegrir (Coletivo de estudantes negros da UERJ)

193

Foto 78 - "VI Censo UERJ_Política de reserva de vagas reduz desigualdades?"

196

Foto 79 -"Arte, Cultura e Ciências Sociais_A Cidade na Universidade." 198

Foto 80 - cartaz feito por alunos do ensino público de base - RJ 200

Foto 81 - "Escola e Universidade. Cartaz CIEP 453_: Negritude e Voz". 201

Fotos 82 e 83 - Jornais de partidos políticos 202

Foto 84 - Informe Asduperj 204

Foto 85 - "Pré-vestibular comunitário UNIRIO: mudança social pela educação" 204

Foto 86 - Pré-Vestibular Comunitário do Sintuperj- UERJ 205

Foto 87 - banner em exposição na UERJ sem muros 206

Foto 88 - Processo eleitoral/CAs - charge de C. Latuff 207

Fotos 89 e 90 - extraídas do mural de Direito da UERJ 209

Foto 91 - Campanha eleitoral/CAs $\quad 215$

Foto 92 "Adesivos CASS_pela assistência estudantil como direito" 218

Fotos 92 e 93 - "Jornal da UERJ_entrevista com o reitor_2" 220 


\section{Introdução}

Este trabalho propõe abordar a investigação das práticas cotidianas na UERJ levando em conta a implementação do sistema de reserva de vagas nesta Universidade, umas das instituições pioneiras na implementação do sistema no contexto brasileiro. Dentre as políticas de ação afirmativa em vigência no país, a ação de maior repercussão foi - e tem sido - a aprovação para reserva de vagas para alunos negros em escolas estaduais, em 2002, tendo como pioneiras a Universidade do Estado do Rio de Janeiro - UERJ, a Universidade Estadual do Norte Fluminense - UENF e a Universidade de Brasília - UNB, acompanhadas por outras universidades entre Estaduais e Federais, em períodos posteriores.

A escolha pelo tema de pesquisa vem se solidificando há tempos. Não é possível separar esta escolha do percurso e trajetória percorridos até o momento de sua realização. Refletir sobre a realidade implica em posicionar-se sobre/com ela. Responsabilizar-se pela posição assumida é o que torna o "cientista" politicamente implicado com sua prática e com seus efeitos.

Um dos compromissos que se assume neste trabalho é o de considerá-lo como uma construção coletiva em um percurso que não depende só do pesquisador e que, ao mesmo tempo considera que sua presença interfere no processo. Outro é o de tomar um tema de tamanha repercussão a partir da complexidade que o mesmo exige. Em outras palavras, preocupa-se, aqui, em trazer o debate sobre a política de reserva de vagas, tornando visível a variabilidade de nuances e de problemáticas que estão em jogo, se considerarmos a complexidade do contexto sócio-histórico e político brasileiro.

A pesquisa "Experiências e táticas no convívio com a alteridade", desenvolvida entre 2005 e 2007, tendo como campo investigativo o cenário da PUC-Rio, trouxe reflexões sobre a experiência do ingresso de estudantes de camadas populares em uma instituição voltada para o público de estudantes das camadas mais favorecidas da população. Corroboraram-se velhas crenças, descortinaram-se novas perspectivas e abriram-se novos questionamentos e a relevância de outras pesquisas na área, sobretudo no campo da ciência psicológica. A discussão metodológica que a observação-itinerante "fez fazer", reafirmou a importância de estabelecer novas diretrizes de pesquisa no campo das ciências humanas, diretrizes estas que resposicionem o pesquisador frente aos sujeitos da pesquisa e ao campo implicando-o no processo tanto quanto nos 
efeitos produzidos - pela presença do pesquisador e pelos acontecimentos da própria pesquisa - no percurso investigativo.

O que a pesquisa anterior fornece de empréstimo, no tocante à discussão metodológica, para esta investigação, não são métodos para serem aplicados "mecanicamente" em outro campo investigativo, mas sim, um modo de pensar/fazer pesquisa que leva em conta a relação do pesquisador com o campo, além das peculiaridades do contexto de pesquisa, determinantes para a escolha das estratégias e dos recursos metodológicos a serem usados.

Dentre as contribuições e relevâncias de uma investigação sobre o tema no âmbito da ciência psicológica, ressalta-se ainda, a transformação do próprio pesquisador durante o processo, tanto em decorrência de um olhar investigativo que se constitui na relação com o campo, quanto pela interlocução com os "coautores" que o atravessam e o interpelam pelo caminho.

As razões da escolha da UERJ como campo de investigação deram-se tanto em função do pioneirismo em relação à implementação da experiência, quanto pela especificidade do uso do critério racial para seleção dos candidatos a serem contemplados pela política. A repercussão que o tema do sistema de cotas para universidades tem assumido e a polêmica que gira em torno dele especialmente no que tange à escolha da questão racial como um dos critérios reforçam a atualidade e necessidade de que todos se impliquem mais profundamente com as polêmicas que a mesma suscita.

A política de reserva de vagas nas universidades, tomando como exemplo o caso da UERJ, tem provocado efeitos e mudanças no cotidiano dos que vivenciam a proposta, incluindo estudantes, ingressantes ou não pelo sistema de reserva de vagas, professores, funcionários/servidores administrativos, grupos militares, entre outros.

Variadas disciplinas de diferentes áreas de formação participam do debate, trazendo as reflexões próprias dos seus campos de saber a partir dos quais focam suas análises e tomando posições frente a temáticas que tangenciam a discussão sobre ação afirmativa e que, em função de sua consolidação, vêm á tona.

Nesta medida se insere o campo da psicologia social e esta é uma das especificidades desta pesquisa. Estão em jogo, quando a ciência psicológica entre no debate, as contribuições possíveis deste campo do conhecimento e os paradigmas através dos quais se pretende por em análise o tema em questão, de relevância para a academia tanto quanto para a promoção de políticas 
públicas e diretrizes prospectivas para o cenário atual da educação superior pública brasileira.

Nestes termos, este trabalho se estrutura da seguinte maneira:

O primeiro capítulo, contextualização histórico-política, tem por princípio situar sócio-políticamente o tema, abordando aspectos relevantes, especialmente no que se refere às divergências tangentes à maiores problemáticas desencadeadas pela consolidação da proposta no país. O cenário da educação superior brasileira e os principais acontecimentos que atravessam a história da educação no país, sobretudo culminando no processo de democratização das universidades e nas políticas de ação afirmativa serão também temáticas tratadas na parte inicial deste trabalho.

O segundo capítulo, a política de reserva de vagas nas universidades públicas brasileiras, tem por intenção trazer os confrontos - de ideias - que têm ocorrido em vários espaços em torno da implementação da política de reserva de vagas nas universidades no país, as vozes, sobretudo acadêmicas, que se conflitam nas arenas de debate, tanto nos cenários em que acontecem as experiências, quando fora deles. Nesta medida, tomar o tema em questão como objeto de análise significa adentrar necessariamente na arena de debates, onde ecoam uma pluralidade de vozes, ora dissonantes, ora consoantes, em que posições se alternam e se entrelaçam.

O terceiro capítulo, metá-hódos em hódos-metá? No registro das paredes que guiam, tem como proposta apresentar o percurso do pesquisador durante 0 processo investigativo. $O$ registro fotográfico e as entrevistas foram etapas que constituíram o caminho metodológico da pesquisa. Refletir sobre este processo, colocando o pesquisador como parte integrante, configura-se como escolha metodológica e os efeitos desta opção serão retratados e constituem parte do material que surge da/na pesquisa. O pesquisador constrói seu olhar sobre/com o campo, observando, relatando e participando do processo.

O ultimo capítulo - os modos de fazer/operar a política de reserva de vagas na UERJ: as práticas cotidianas nas vozes dos interlocutores - aborda as problemáticas e os principais aspectos que surgem da pesquisa, no diálogo com as reflexões de alguns autores, como M. Certeau e M. Bakhtin, dentre outros. São analisados, a partir das entrevistas, tanto as fotografias, que funcionam como disparadoras de reflexões sobre o tema, quanto os discursos dos sujeitos da pesquisa.

A relevância da psicologia em participar do debate, na interface com outras áreas do conhecimento, além da atualidade e grande repercussão do tema no 
cenário sócio-político mais amplo, põem em relevo a importância do trabalho, estabelecem diretrizes para contribuições no campo da psicologia, além de suscitarem desdobramentos para pesquisas e investigações futuras.

\section{Contextualização histórico-política}

\subsection{Introdução}

A política de reserva de vagas nas universidades públicas brasileiras tem deflagrado, desde a sua implementação, inúmeras discussões, controvérsias, impasses como também significativos avanços e estratégias de enfrentamento.

Desde sua implementação até o momento atual - em que o número de universidades com adesão à política supera 66, entre federais e estaduais -, o teor das discussões e argumentações se complexificou, tomando novos formatos.

De modo geral, pode-se considerar que, passados aproximadamente quase dez anos das primeiras experiências no país, as discussões em torno de posições favoráveis ou contrárias à política foram superadas - refiro-me ao debate que divide as posições de modo maniqueísta, simplificando a discussão. Neste sentido, ao que tudo indica, este debate, especialmente em se tratando dos espaços acadêmicos, tomou novo formato. Claro é, contudo, que algumas posições permanecem, umas manifestas, outras silenciosas. No entanto, ganham espaço as discussões à respeito das "políticas de permanência", entre outras questões, na medida em que cada instituição passa a se deparar com novas problemáticas e demandas, considerando o ineditismo da política no país e as particularidades de seus contextos de implementação.

Independente do posicionamento permanece consensual a importância de um debate profícuo sobre o tema e de esclarecimentos mais contundentes sobre - que, de fato, consiste a política de reserva de vagas, nos seus atravessamentos e estratégias de ação.

Este capítulo tem por princípio situar sócio-politicamente o tema, abordando aspectos relevantes, seja do ponto de vista histórico-político, seja no que se refere às divergências tangentes às maiores problemáticas desencadeadas pela consolidação da proposta no país.

Aos que participaram, se não, presenciaram de forma mais atenta, seja nos "círculos de debate" e/ou por meio dos veículos midiáticos, ficaram sobressalentes as tensões e conflitos que permeavam as primeiras experiências 
da política no país, e a tendência, num momento preliminar, como já foi dito, em situar o debate em dois pólos antagônicos: de um lado extremo os favoráveis e do outro os contrários à proposta.

Diferentes pontos de vista e variados argumentos conduzem as discussões. Alguns aspectos foram mais recorrentemente enfocados a exemplo da constitucionalidade ou não da medida, do princípio da meritocracia como premissa básica para aprovação no exame vestibular, do uso do recorte racial como condição para concorrer às vagas reservadas e as controvérsias quanto aos critérios de definição, do tema do racismo no Brasil e, portando, do "mito" da democracia racial, da qualidade de ensino nas universidades de excelência e da ameaça de perda desta qualidade, do caráter provisório da política de ação afirmativa, da necessidade de melhoria no ensino público de base, entre muitos.

As fundamentações, num momento preliminar, foram imprescindíveis para o amadurecimento da discussão e das ações propositivas mas, posteriormente, mostram-se incipientes frente à complexidade da temática e aos impasses que aparecem com a efetivação desta política num contexto com as peculiaridades históricas e políticas de nosso país. Logo, para a compreensão destas problemáticas faz-se necessário visibilizar as especificidades do cenário sóciohistórico brasileiro que tornaram e tornam a experiência da ação afirmativa no ensino superior neste país, peculiar se comparada às demais. É o que salienta Vieira (2003):

É certo que a adoção de um modelo de ação afirmativa no Brasil não pode ser feita tendo como parâmetro principal aquele envolvido em outros países, como nos Estados Unidos, até mesmo porque é certo também que o Brasil parece trilhar um caminho oposto, quando se compara às demais experiências desenvolvidas. (Vieira, 2003: p.93)

Não pode se perder de vista que o caso brasileiro reflete as tensões e nuances das experiências e políticas em escala mundial.

As ações afirmativas são políticas públicas legitimadas pelo Estado para minimizar as desigualdades, com a função de garantir direitos equânimes a grupos que, embora numa sociedade dita "democrática", têm tido seus direitos vilipendiados. Ora, seria equivocado acreditar que, somente por seu caráter de política pública, legitimada via projeto de lei, os méritos de sua consolidação seriam exclusivamente conferidos ao Estado. É preciso analisar os efeitos de uma prática, não somente a partir da ação de um elemento, de forma isolada, mas, na dinâmica entre os vários atores envolvidos. Entender essas relações é 
condição básica para a compreensão das experiências de ação afirmativa, hoje, sobretudo no campo educacional.

É preciso refletir sobre a conjuntura política que possibilitou a participação/ação do Estado na consolidação de um projeto desta natureza. Várias questões se colocam. Vejamos algumas delas:

(1) Que projeto político de sociedade encontra-se na base de um governo que se propõe legitimar políticas de cunho afirmativo? Como situar a educação neste projeto político?

(2) Qual a relação entre os ideais preconizados pelo projeto democrático de sociedade - em destaque os conceitos de igualdade e liberdade , e os conceitos-chave prementes no sistema capitalista de produção?

(3) Quais as relações/tensões entre a Sociedade Civil e o Estado que se estabelecem, de modo mais geral, a partir dos diferentes projetos políticos de governo?

Estas questões refletem a complexidade da temática e a importância de uma análise mais aprofundada sobre questões a ela subjacentes. Menos que pretender apresentar um conteúdo explicativo, intenciona-se mais mapear alguns conceitos que tangenciam a discussão, de modo a favorecer o posicionamento frente ao tema.

O avanço das discussões se confirma na variedade de publicações encontradas sobre a temática, em diversas áreas do conhecimento. É, pois, com o auxílio destas reflexões, que se pretende situar melhor o cenário históricopolítico no qual se concretizam as experiências na cena brasileira, considerando, sobretudo, a dimensão dialógica que o tema implica, o que corrobora a premissa de que as fronteiras interdisciplinares estão cada vez mais arrefecidas, especialmente na cena contemporânea. Situemos, pois, este cenário.

\subsection{Democracia, Cidadania e Justiça Social: Reflexões Preliminares}

O ideário democrático nem sempre - diz Tavares e Moisés (2005) - se consolidou na experiência prática, especialmente se consideramos o momento atual. Recorrendo à etimologia da palavra, de origem grega - "poder do povo"pode-se entender por cidadania, participação efetiva dos sujeitos da cidade nas decisões/deliberações de seus rumos. Contudo, no trecho abaixo destacado, os autores apontam contradições entre o significado do termo democracia, na sua acepção original, e sua experiência concreta na vida prática, já na época da concepção da palavra, na Grécia. 
Etimologicamente, desvela um significado perseguido por todas as gentes que anseiam por liberdade e por beleza. Demos (povo), Kratos (poder). Poder do povo. Tão singelo quanto falso (...) O povo para a democracia grega eram os varões, os proprietários, os ricos, os sábios. (2005: p.68)

Não somente os detentores do poder, na antiga Grécia, deturpavam, na prática, o sentido do ideal democrático, tal qual sua real significação etimológica. Em Aristóteles e Platão, o poder político da cidade não poderia ficar a cargo de sujeitos desprovidos de razão, um "cidadão sem sabedoria", (p.68) sob o risco de constituir "um governo dos pobres" (p.68).

A incompatibilidade entre os ideais democráticos e a participação popular acirra-se quando, dentre os pressupostos do pensamento liberal surge, no século XVIII, o do direito individual à propriedade privada. (Tavares e Moisés, 2005). Gohn (2001), citando Diderot, afirma que, segundo esta perspectiva, "a propriedade privada faz o cidadão" (p.11). Neste sentido, a posse de propriedades presumia condição de independência econômica "necessária à liberdade de espírito e ao desprendimento das paixões" Logo, "só os proprietários tinham direito à plena liberdade e à plena cidadania" (2001, p.12)

É ainda Gohn (2001) que diferencia o conceito de cidadania para a classe trabalhadora e a burguesia. Segundo essa autora, os trabalhadores não eram cidadãos, já que não eram capazes de agir de modo racional, politicamente.

Os assalariados seriam incapazes de pensar. (...) eles seriam incapazes de governar suas vidas por princípios de ordem moral (...) suas ações não poderiam saber, apenas precisavam acreditar. A educação para a cidadania não faria parte da classe trabalhadora porque ela não era cidadã. (p.12)

É na Revolução Francesa, 1789, que o "povo" adentra a cena política, tomando os princípios de liberdade, igualdade e fraternidade como direitos humanos fundamentais.

Diante da ameaça de perda de poder por parte da burguesia, entretanto, a chamada "democracia representativa" entra em cena, transferindo a responsabilidade dos poderes decisórios para os representantes, "escolhidos" através do voto popular. O voto passa a constituir, então, a principal ferramenta de garantia - ou "suposta" garantia -, do exercício democrático. Contudo, salientam os autores, o exercício desta democracia representativa encontrava barreiras quando a garantia dos direitos de todos significava ameaça aos privilégios e interesses das classes dominantes: 
Hoje o conceito de democracia alardeado pelos poderosos do mundo segue sendo o de governo do povo, para o povo e pelo povo, alicerçado no voto e na representação. Mas uma condicionante permanece, ainda que escondida para as massas: o povo vota e decide, desde que não ameace o poder, a propriedade privada e os interesses da classe dominante. (Tavares e Moises In: Rampinelli, et alli, 2005: p.70)

Vale dizer que transformações nas concepções de cidadania marcam o século XVIII, época em que o racionalismo ilustrado enfatiza a razão atribuindo à história a "evolução do espírito", propondo, então, uma mudança nas ordens social e política vigentes. Para tanto, seria preciso intervir na consciência e na instrução, possibilitando ao homem tornar-se "sujeito histórico capaz de modificar a realidade" (Gohn, 2001, p.13). É neste sentido que se justifica a educação enquanto ferramenta de garantia da cidadania. "A questão da cidadania se resumiria a uma questão educativa" (p.13)

Estas palavras, contudo não podem ser as últimas, tendo em vista as relações de poder que se configuram no cenário político vigente. O sistema capitalista transmuda o sentido de educação como liberdade de pensamento e posicionamento político para obediência e passividade, logo, "mecanismo de controle social" (p.13), tendo por finalidade principal um "povo ordeiro, obediente a seus superiores e não presa de crendices e superstições religiosas e místicas". (Gohn, 2001, p.13) A autora completa:

O que a economia clássica do século XVIII propôs foi o cidadão passivo. Não importava o povo como sujeito político - tal como preconizavam os ilustrados. O que interessava era que as massas se tornassem ordeiras no seu convívio social, 'no seu devido lugar'. O essencial era instruir, racionalizar o indivíduo, mas racionalizar a vida econômica, a produção, o tempo das pessoas, o ritmo dos corpos, a disciplina das mentes. Ou seja, a única educação que interessava era a formação e produção da mercadoria para o trabalho. (p.14)

O que fica proeminente é um deslocamento de uma cultura com foco na cidadania para outra focalizada no poder. Desta forma, a cidadania do século XIX, segundo Gohn (2001), passa a incluir o sujeito das massas, com a intenção maior de manutenção da ordem e controle sociais. Prevalecem os conteúdos utilitaristas, uma prática pedagógica que privilegia "estratégias de persuasão, esclarecimento e moralização" (p.14) dos sujeitos, sendo o Estado o provedor dos direitos, mas como "dádiva", não como conquista. Melhor dizendo, o princípio dos direitos humanos incorria mais nos deveres e menos neles próprios.

Estas reflexões encaminham para uma análise mais abrangente, abordando, desta vez, os conceitos de cidadania e justiça social. Não há meios 
de refletir sobre as políticas de cunho afirmativo, nas suas experiências e embates, sem antes referenciar a concepção de democracia nos rumos por ela tomados na sociedade contemporânea.

Falar em cidadania hoje -, termo recorrentemente utilizado nos últimos tempos por pesquisadores e atores envolvidos em projeto sociais, nas áreas de educação, psicologia, sociologia e afins - implica, necessariamente, em considerar as condições macroestruturais da sociedade que possibilitam e/ou obstaculizam seu exercício pleno.

A criação de um conjunto de estratégias de enfretamento com vistas à "promoção da cidadania" na cena contemporânea, especificamente no Brasil, se justifica pelo fato de que, nem todos os "cidadãos" usufruem, na prática, desta condição neste país. Logo, falar em "condição de cidadão", hoje, significa mais nos remetermos à sua negatividade: a "condição de não-cidadão".

O "indivíduo sem rosto" de Da Matta (1992) presentifica essa dimensão ausente: "ausente de reconhecimento social (...) sem direitos e sem recursos" (p.06). Incitado a comentar sobre o que entende por "cidadania brasileira" melhor dizendo, "cidadania à brasileira"-, o autor remete-nos ao sujeito comum, nomeado de "Zé da Silva", não o Zé da Silva, único, singular, mas o representante de uma categoria de "Zés".

Imaginando o cidadão, vejo a empregada doméstica conhecida apenas pelo apelido ou pelo primeiro nome. Não sabemos onde ela mora e nem o seu nome todo. Vejo apenas o rosto sofrido dos milhões que vagam pelas filas de triagem dos hospitais públicos, querendo receber uma palavra de efetivo reconhecimento social e político. Uma palavra que diga que eles são parte de alguma coisa e que sua existência (sem o cargo oficial, sem dinheiro no banco, sem diploma universitário) tem algum valor! (p.07)

Ora, é preciso tomar contato com a variedade de denotações em torno do termo cidadania. Tomemos contato com algumas delas, a começar pelas palavras de Castro (2001):

A conquista da cidade faz parte da tarefa de se tornar cidadão, já que exige o conhecimento da cidade, e melhor ainda, o amor à cidade. (...) tanto sentir-se parte como identificar-se constituem condições subjetivantes da cidadania, isto é, só haverá exercício efetivo da cidadania quando este sujeito (...) encontre condições que favoreçam seu pertencimento e sua identificação a algo maior que é a sua nação e o seu Estado. (Castro, 2001: p.117)

É Castro (2001) ainda que, discutindo sobre a participação de crianças e jovens na cidade urbana contemporânea, nos fornece elementos para a análise do tema. Citando Carvalho (2001) associa três aspectos, balizados pelos direitos fundamentais do homem, de acordo com o ideal republicano e democrático de 
sociedade que, em conjunto, representariam a garantia da condição plena de cidadania. São eles os direitos civis, os políticos e os sociais.

Segundo explica: "Os direitos civis são os direitos fundamentais à vida, à liberdade, à propriedade e à igualdade perante a lei." (Carvalho, 2001: p.117) Os direitos sociais seriam os que garantiriam a vida sob condições humanas favoráveis, à exemplo de jovens e crianças em situação de abusos ou maus tratos, considerando suas condições de vulnerabilidade. É neste sentido que projetos sociais são criados com vistas a garantir a proteção dos direitos negligenciados. Por fim, os direitos políticos:

Quando falamos em direitos políticos, referimo-nos especificamente aos direitos de cada um de participar dos destinos da sociedade, ou seja, de como podemos influir na construção coletiva da sociedade. (p.116/117)

Há que se retomar a discussão inicial que articula democracia e cidadania, uma vez que os princípios que pautam um projeto de sociedade democrático são incongruentes com a experiência prática vivida pelos sujeitos citadinos, fazendo referência às sociedades em que prevalecem relações desiguais sob pontos de vista diversos.

É dessa incoerência a que Salvador (2008) se refere quando usa a expressão "desigualdade social estrutural', pondo em discussão as experiências de cidadania no contexto brasileiro. Os sujeitos neste país teriam, conforme Carvalho (2005 in: Salvador, 2008), três possibilidades, circunscritas nas designações a seguir: "O cidadão pleno, aquele que desfruta dos direitos civis, políticos e sociais; o cidadão incompleto, que possui apenas alguns direitos, e o não-cidadão, o sujeito que não se beneficia de nenhum direito". (Salvador, 2008: p.25).

As descrições feitas em segundo e terceiro lugares são, certamente, as que prevalecem na cena cotidiana brasileira, culminando na condição de "cidadania restrita", expressão usada por Salvador (2008) em que se refere à recorrente e naturalizada ausência de direitos, especialmente os sociais, com destaque aos referentes à saúde, à alimentação, à educação de qualidade. Pronto. Tocamos num dos pontos centrais do tema: a educação como um dos bens fundamentais e como condição básica para o exercício da cidadania, isto é, cidadania plena.

O exercício de cidadania tem na educação o terreno mais propício para sua efetivação, logo, na mesma medida, a ausência de uma educação de qualidade para todos seria grande impeditivo desse exercício. As razões são 
várias e não estão restritas ao acesso ao conhecimento, em si, mas, sobretudo, às relações estabelecidas na sociedade, em função da posição de cada sujeito na estratificação sócio-política a partir da condição de inacessibilidade.

Dias Sobrinho (2011) considera a educação como um dos temas mais importantes na época atual, quando se fala em justiça social e em um projeto de sociedade democrático. Assim sendo, deveria ser dever do Estado assegurar o acesso igualitário e de qualidade para todos; a educação seria um direito social tanto quanto um bem público. $\mathrm{O}$ autor entende que: "O direito social à educação de qualidade é um aspecto essencial e prioritário da construção da sociedade, de consolidação da identidade nacional, e um instrumento de inclusão socioeconômica.” (p.121)

Recorrendo ao "não-cidadão" de Da Matta (1992), brasileiro, "sem direitos e sem recursos", aquele que está submetido à lei geral e, ao mesmo tempo, e, portanto, condenado ao anonimato, o "sem o carro oficial, sem dinheiro no banco, sem diploma universitário" (p.07), acrescenta-se, "sem acesso à educação básica", portanto, cerceado nos seus direitos de constituir-se enquanto ser social nas suas condições básicas de existência. Partindo do entendimento de educação enquanto processo de formação humana - para além do sentido exclusivamente utilitarista a ela conferido pela lógica do mercado -, Dias sobrinho (2011) acredita que "a educação deve ser vista e organizada como um sistema"; cujo tempo é "total, permanente, contínuo, pois se trata de um processo jamais acabado de formação humana." (p.122)

Sobre os efeitos da exclusão na educação, valem ainda suas considerações:

As diversas etapas de escolarização formal organizam os processos de formação que farão parte da vida de toda a pessoa. A exclusão escolar, em qualquer etapa, é privação de algumas bases cognitivas e axiológicas que todo individuo e ser social necessita para edificar uma existência humanamente significativa. (p.122)

Considerando o acesso à educação como importante dispositivo para o exercício da cidadania - garantia de visibilidade, participação social e política efetivas, é compreensível e, justificável, o surgimento de diferentes propostas de ação no campo educacional, em amplitude mundial e, em especial, no Brasil. Prevalecem, neste país, desigualdades sociais e econômicas, ainda bastante proeminentes na época moderna, culminando em injustiças de toda ordem.

A "educação" seria, portanto, um campo de extrema relevância no combate à desigualdade social por, dentre outras razões, consistir em parte constitutiva da cidadania e da "consolidação da democracia" (p.218), além de "fato de 
promoção da mobilidade social e de acesso de maior poder econômico, principalmente quando se trata da primeira geração da família que nela se forma(...)" (p.218)

Dias Sobrinho (2011) analisa o conceito de inclusão social, tão amplamente debatido nos dias atuais, especialmente nos arredores acadêmicos, importante para refletir sobre os processos de exclusão/inclusão e a educação como dispositivo, incorrendo em medidas propositivas capazes de reverter a lógica excludente. Compreende, contudo, que a educação deve ser pensada no conjunto mais amplo de bens fundamentais que devem ser garantidos a todos e, acima de tudo, pelo Estado. Inclui como importantes dispositivos de análise sobre o tema, tanto:

Processos de degradação das relações sociais em geral como das relações no mundo do trabalho, dos direitos sociais ou políticos e, também, (...) problemas decorrentes da incapacidade do Estado de oferecer, de forma homogênea, serviços públicos como educação, saúde, saneamento, segurança. (p.223)

A visão do Estado como garantidor dos direitos fundamentais, sendo um dos primordiais a educação, impõe a necessidade de refletir sobre os modelos políticos de sociedade, com ênfase na função estatal e sobre as aproximações com os processos de desigualdade social prementes na atual conjuntura. A importância desta discussão se confirma quando Dias Sobrinho (2011), e vários outros teóricos, associam aos processos de exclusão social a "ausência de direitos básicos e as dificuldades dos indivíduos para deles usufruírem" (p.223). Mais do que isso, na medida em que compreende este fenômeno como resultado de um Estado desarticulado à noção de responsabilidade social e de um sistema baseado no capital e na lógica do mercado. Entende que: "A exclusão social é uma característica intrínseca ao capitalismo, um dado estrutural do capitalismo mundial (...) a miséria e a exclusão resultariam dos desdobramentos contínuos do modo de produção capitalista" (2011, p.224)

É preciso que sejam estabelecidos os parâmetros que norteiam um projeto político educacional de qualidade, capaz de garantir o exercício da cidadania de forma indiscriminada, com vistas à garantia de justiça social. Os caminhos para se pensar numa proposta de educação que seja para todos, em consonância com a qualidade de ensino, serão estabelecidos tomando como norte as indagações feitas por Dias Sobrinho (2011), quando o mesmo relativiza a expressão "qualidade educacional" conferindo certa variabilidade aos tempos, espaços e grupos sociais. Em se tratando do tema "qualidade na educação", 
indaga: "Qual educação? Qual conhecimento? Qual sociedade?" (p.123). E completa mais adiante:

Qualidade não é nunca um conceito neutro e desideologizado. Dado que a compreensão das realidades, os interesses e projetos individuais e corporativos são heterogêneos, contraditórios e mesmo conflituosos, impossível haver ampla e permanente unanimidade a respeito do que é e deveria ser uma educação de qualidade. (p.126)

Dito isto, de modo à por em reflexão esta temática, tomo por base uma proposta concreta no campo da educação formal básica apresentada por Romão (2004), de título Projeto Escola Cidadã, para introduzir discussões importantes para compreensão do cenário sócio-político atual brasileiro. Romão (2004) nos fornece alguns elementos com as diretrizes da proposta. Vejamos do que se trata.

\subsection{Educação e Cidadania: Problemáticas Contemporâneas}

Tomando como ponto de partida o projeto educacional que preconiza a distribuição dos recursos públicos de forma equânime e a participação coletiva nas decisões, Romão (2004) aposta na "universalização do processo decisório, para a inserção competente de todos no sistema produtivo e para a socialização do usufruto da riqueza social." (Romão, 2004: p.147). Contextualizando, a aposta baseia-se em um projeto político-pedagógico, sob o título "Escola Cidadã". Trata-se da proposição de um modelo alternativo de pensar/fazer educação, se comparado aos excludentes e atualmente hegemônicos, que concebe uma escola nos seguintes moldes:

(a) estatal, enquanto escola mantida com recursos públicos; (b) pública, enquanto dirigida a todos, sem nenhuma discriminação; (c) comunitária, enquanto escola pensada, dirigida e administrada por uma sociedade que se responsabiliza efetivamente por ela. (Romão, 2004: p.147)

O caso do projeto "Escola Cidadã", acima referido, é digno de nota não somente por seu caráter crítico, no sentido de por em análise os processos de exclusão/inclusão no campo educacional no Brasil, quanto por nos fornecer subsídios para a construção/viabilização de um novo modelo de projeto políticopedagógico, com vistas à garantia dos princípios democráticos basilares.

Por ora, a referida experiência nos convoca a estabelecer um paralelo entre Democracia e projeto político de gestão, apontando caminhos para uma análise mais profícua sobre o tema da ação afirmativa, especificamente no 
ensino superior brasileiro. Tomemos o "Projeto Escola Cidadã", nas suas principais premissas, como fio condutor, fazendo uma análise mais atenta dos dois primeiros pontos, separadamente:

A escola cidadã básica é aquela que se caracteriza por ser uma escola: (a) estatal, enquanto escola mantida com recursos públicos;(...) (Romão, 2004: p.147)

Uma escola estatal pressuporia ser responsabilidade do Estado, no seu papel de gerenciador e distribuidor dos recursos públicos, a garantia do funcionamento da instituição. Este modo de entendimento de gestão política, tendo o Estado como peça central na administração dos recursos e na provisão dos direitos fundamentais, como a educação, dentre outros, aponta para uma lógica de gestão em consonância com princípios de um projeto socialista de Estado: contracorrente, tendo em vista que, no contexto histórico-político contemporâneo, vigora o modelo capitalista de produção, que encontra na perspectiva neoliberal terreno fértil para o seu desenvolvimento.

A compreensão das direções e dos posicionamentos das correntes políticas dos pensamentos neoliberais e social-democratas, especificamente no que diz respeito ao papel conferido ao Estado, fornece subsídios para a discussão sobre cidadania e democracia, nas suas contradições atuais. É o que pensa Torres (1995), quando se propõe a discutir, separadamente, as visões e práticas do Estado em dois modelos de gestão: O Estado de Bem-Estar Social e o Estado Neoliberal. Tomemos de empréstimo suas proposições. Com a vez, o primeiro modelo:

O Estado de bem-estar social representa um pacto social entre o trabalho e o capital.(...) Mais recentemente o new deal, concebido por Roosevelt nos Estados Unidos, constituiu uma formação de governo na qual os cidadãos podem aspirar a níveis mínimos de bem-estar social, incluindo educação, saúde, seguridade social, salário e moradia, como um direito de cidadão, não como caridade. (p.113)

Sobre o papel do Estado neste projeto de gestão:

O princípio do novo Estado de Bem-Estar Social é investir em 'capital humano' e não pagar diretamente os benefícios. Surge assim a idéia de sociedade de bem-estar. O Estado faz parcerias com empresas e ONGs para a criação de empregos, desobrigando-se do salárioemprego. Faz parcerias com empresas de saúde e se desobriga da saúde pública gratuita; faz o mesmo com empresas de educação, e assim por diante. A função do estado social é dupla. Em primeiro lugar, excluir, sem danos aparentes, a idéia de vínculo entre justiça social e igualdade socioeconômica. Em segundo, desobrigar-se de lidar com o problema da exclusão e da inclusão de ricos e pobres. (Chauí, 2005: p.331)

De outro modo, vejamos o que ancora o pensamento neoliberal, focalizando a função estatal, segundo Torres (1995): 
Neoliberalismo, ou estado neoliberal, são termos empregados para designar um novo tipo de estado que surgiu na região nas últimas décadas.(...) os governos neoliberais propõem noções de mercados abertos e tratados de livre comércio, redução do setor público e diminuição do intervencionismo estatal na economia e na regulação do mercado .(...) um aspecto central deste modelo é a redução drástica do setor estatal, especialmente mediante a privatização das empresas paraestatais(...), (dentre outros aspectos). (p.113)

Conferindo ao Estado um papel reduzido e ao capital privado a função de "prover" ou fornecer as "opções" de acesso à educação, saúde e outros recursos básicos, o neoliberalismo implica na:

(...)diminuição da participação financeira do estado no fornecimento de serviços sociais (incluindo educação, saúde, pensões e aposentadorias, transporte público e habitação populares) e sua subseqüente transferência ao setor privado (privatização). A noção de privado - e as privatizações - são glorificadas como parte de um mercado livre, com total confiança na eficiência da competição, onde as atividades do setor público ou estatal são vistas como ineficientes, improdutivas, anti-econômicas e como um desperdício social, enquanto o setor privado é visto como eficiente, efetivo, produtivo, podendo responder, por sua natureza menos burocrática, com maior rapidez e presteza às transformações que ocorrem no mundo moderno.(...) (p.115)

Ora, no trecho: "o setor privado é visto como eficiente, efetivo, produtivo(...)"(p.115), verifica-se a aproximação entre a perspectiva neoliberal e o sistema capitalista de produção. Neste sentido:

\begin{abstract}
Diferentemente da forma Keynesiana e social-democrata, que define o Estado como agente econômico para regulação do mercado e agente fiscal que emprega a tributação para promover investimentos nas políticas de direitos sociais, agora o capitalismo dispensa e rejeita a presença estatal não só no mercado, mas também nas políticas sociais, de sorte que a privatização tanto de empresas quanto de serviços públicos também se torna estrutural. Em decorrência disso, a idéia de direitos sociais como pressuposto e garantia dos direitos civis ou políticos tende a desaparecer porque o que era um direito se converte num serviço privado regulado pelo mercado e, portanto, torna-se uma mercadoria a que têm acesso apenas os dotados de poder aquisitivo para adquiri-la. (Chauí, 2005: p.321)
\end{abstract}

Sobre os paradigmas capitalistas e seus efeitos no campo educacional, partindo do entendendo de que, na sociedade do capital, tudo se mercantiliza (Gentili, 1995), seria coerente associar a educação a mais uma das mercadorias, limitando seu acesso ao "poder de compra" de cada indivíduo e à posição por ele ocupada na estratificação hierárquica social. O consumo: eis o elemento de força propulsora fundamental para o sistema capitalista nos dias atuais. A educação, como dito, assume o lugar de mercadoria, num sistema de produção que encontra nas tendências de um projeto político de sociedade, terreno fértil para sua materialização. 
Partindo da noção de neoliberalismo, sob o viés político, "(...) como encolhimento da esfera pública e ampliação da esfera privada."; Chauí (2005: p.317) cita alguns elementos próprios do modelo capitalista de produção, no seu atual formato. $O$ entendimento da educação como mercadoria e a redução do papel estatal podem ser ilustrados por alguns destes aspectos:

\begin{abstract}
O desemprego passa ser estrutural, isto é, deixa de ser acidental ou expressão de uma crise conjuntural, porque a forma contemporânea do capitalismo, ao contrário de sua forma clássica, não opera por inclusão de toda a sociedade no mercado de trabalho e de consumo, mas por exclusão(...) (p.319) 2. O monetarismo e o capital financeiro tornam-se o coração e o centro nervoso do capitalismo, ampliando a desvalorização do trabalho produtivo e privilegiando a mais abstrata e fetichizada das mercadorias, o dinheiro(...). 4. A ciência e tecnologia tornam-se forças produtivas, deixando de ser mero suporte do capital para se converter em agentes de sua acumulação. (...) a força e o poder capitalistas encontram-se agora no monopólio do conhecimento e da informação. Surge a expressão 'sociedade do conhecimento' para indicar que a economia contemporânea não se funda mais sobre o trabalho produtivo e sim sobre o trabalho intelectual, ou seja, sobre a ciência e a informação, pelo uso competitivo do conhecimento, da inovação tecnológica e da informação nos processos produtivos. (p.320)
\end{abstract}

As considerações precedentes apontam para certa transformação na estrutura hierárquica sócio-política, no contemporâneo, traduzindo-se pela substituição da divisão de classes por competentes, por isso, comandantes e, incompetentes, então, comandados. A "ideologia da competência", como denomina Chauí (2005), significa que, os detentores do conhecimento estabelecem as regras, na qualidade de "especialistas", restando ao demais executá-las e aceitar os desdobramentos destas ações. Tal estrutura deflagra as contradições de um sistema democrático, que se propõe igualitário do ponto de vista social e, no entanto, que se apresenta incompatível na prática, frente a uma lógica de produção que tem como ferramentas de acesso aos recursos básicos a competição e a meritocracia. Reservemos este último conceito para uma discussão mais contundente em momento apropriado. Por ora, não percamos de vista os princípios que alicerçam o projeto-norte desta discussão.

A escola cidadã básica é aquela que se caracteriza por ser uma escola: (b) pública, enquanto dirigida a todos, sem nenhuma discriminação. (p.147)

Gentili (1998) chama a atenção para a expansão das relações mercantis para todos os âmbitos da vida humana. A mercantilização, enquanto âncora para as relações e entremeando os valores sociais, é introjetada como valor humano, presentificando-se, mais do que tudo, na materialidade da consciência dos sujeitos. "No capitalismo histórico, tudo se mercantiliza, tudo se transforma em valor mercantil." (p.228) 
Partindo do entendimento de uma sociedade mercantilizada em todas as esferas da vida humana, Gentili (1998) nos faz analisar as razões em função das quais a educação assume um lugar de mercadoria - consoante às posições precedentes - afastando-se da idéia de um direito social e da escola pública como espaço propício de consolidação deste direito. É neste sentido que o autor aponta a disseminação dos pressupostos neoliberais na direção da consolidação de uma "antidemocracia" política. (p.230)

A proposta de um projeto político-pedagógico intitulado "escola cidadã", que tem como umas das premissas "uma escola dirigida a todos indiscriminadamente", tem grande importância, especialmente no Brasil, no cenário educacional atual, pelo fato das escolas públicas brasileiras serem dirigidas à grande massa, enquanto as privadas são receptáculos das camadas mais favorecidas da população. Constatação nada original, visto que é fato conhecido. O que é preciso fazer é focalizar na gênese do problema: De que forma a díade escola públical privada tornou-se o reflexo das contradições sociais resultantes dos processos de exclusão/inclusão no Brasil?

As diretrizes para análise da questão podem ser várias. Uma delas seria retomarmos as perspectivas da corrente de pensamento e do projeto político neoliberais.

As palavras de Gentili (1998) apontam para transformações na conjuntura global, que não se restringem aos setores da vida econômica e social, mas que, proporcionalmente, operam sobre a ordem cultural vigente.

Em que pese as conseqüências mais recentes deste momento pós-crise do capital, acima descrito, nas suas peculiaridades históricas, a desigualdade estrutural não tem sua origem no período neoliberal. Todavia, é, pois, marca desta corrente de pensamento, como bem salienta Gentili (1998), o acirramento cristalino de um "modelo social fundado na dualização e marginalização crescente de setores cada vez mais amplos da população" (p.233). Em pauta, os conceitos de meritocracia e de individualização como elementos determinantes desta lógica estrutural.

As sociedades dualizadas - sociedades de ganhadores e perdedores, de insiders e outsiders, de integrados e excluídos - longe de apresentarem-se como um desvio patológico do aparentemente necessário processo de integração social que deveria caracterizar as sociedades modernas, constituem hoje uma evidência indisfarçável da normalidade que regula o desenvolvimento contemporâneo das sociedades 'competitivas'. (p.234) 
Com vistas a corporificar a análise sobre a temática da educação como mercado e a possibilitar ações prospectivas em pesquisa sociológica sobre o tema, Ball (1998) trata - no artigo "Mercados Educacionais, Escolha e Classe Social: O Mercado como uma Estratégia de Classe"-, dos efeitos da lógica mercadológica sobre as escolas e, ideologicamente, sobre as famílias contemporâneas.

A autora chama a atenção para a existência de uma "cultura da escolha" atrelada a uma "ideologia de mercado", que centraliza nos pais a "opção" pelas instituições educacionais, que tomam, por sua vez, como parâmetro a lógica do lucro e dos investimentos em educação. (p.196). Em poucas palavras, tendo a escola como mercadoria de consumo, os pais assumem o papel de "decidir" que "tipo" de educação desejam proporcionar para seus filhos, o que alimenta a lógica da competitividade entre as instituições a serem "escolhidas". Está-se falando, indubitavelmente, de um mercado educacional privado em que o investimento determinará o aumento ou redução da procura. Inevitável, então, que o maior poder de consumo das famílias determine o perfil de alunado de cada instituição.

Quanto à escolha dos critérios usados como base para qualificação de uma ou outra instituição, seria preciso recorrer à uma análise das concepções de educação bem como dos projetos de sociedade a elas relacionados.

A implementação de reformas educacionais baseadas no mercado constitui essencialmente uma estratégia de classe que tem como um de seus principais efeitos a reprodução de vantagens e desvantagens ligadas à classe social (e à etnia). (p.197)

Ball (1998) menciona algumas justificativas usadas em desfavor da escola como patrimônio público e outras em defesa do mercado educacional privado, da escolha da educação como mercadoria de consumo. As argumentações caminham na direção de um empreendedorismo educacional e sua apropriação prática produz mudanças nas acepções originais de democracia, cidadania e igualdade.

No conjunto das desfavoráveis estariam: a desvinculação de forma direita do incentivo/investimento financeiro, oriundo do pagamento dos impostos, da "satisfação dos clientes"; a burocratização "ineficiente" atribuída ao Estado frente ao monopólio educacional, o que, além de outros fatores, reduziriam os "padrões de excelência" das institucionais em questão.

Os argumentos pró-mercado educacional tomam por parâmetro os modelos educacionais norte-americanos que consistem em: maior sensibilidade e motivação por parte dos diretores das escolas em acolher as demandas dos 
pais; possibilidade de transferência de recursos e de alunos de escolas com menor popularidade e "padrão de qualidade" para as de menor prestígio social, o que culminaria no possível fechamento ou mudanças de escolas "menos qualificadas", o que Ball (1995) chama de uma espécie de "seleção natural" (p.199)

As tendências anteriores produzem os seguintes efeitos, dentre vários: conferem certa "autoridade educacional às famílias, dando-lhes poder de "escolha" frente aos modelos de educação oferecidos pelo mercado na área e, paralelamente, minimizam ou extinguem a influência dos governos locais "instituições democráticas intermediárias"(p.202) - e as "autoridades educacionais" no processo de gestão pedagógica das instituições. As conseqüências disso? A autora abrevia da seguinte forma: "O que está sendo construída é uma democracia do consumo, em vez de uma democracia da cidadania." (Ranson, 1990, p.15 in: Ball,1995, p.202)

A expressão "democracia do consumo" põe em relevo a incompatibilidade entre as concepções de igualdade e de cidadania quando se trata do campo educacional, especialmente nos dias atuais. Retomemos o Projeto Escola Cidadã, quando este preconiza uma escola necessariamente "pública, enquanto dirigida a todos, sem nenhuma discriminação" (p.147): a "democracia do consumo" aponta para o seu reverso. A escola gerida pelo mercado seria aquela: "cuja entrada é difícil e que produz resultados superiores em termos de desempenho." (p.221), o que não seria possível em um cenário perverso de desigualdades de condições, favorecendo uns e desfavorecendo outros na competição pelo acesso à educação.

Cabe considerar, sobretudo, o grande paradoxo que se apresenta quando a concepção de escola ideal baseia-se na equidade e eficiência e, concomitantemente, no atendimento às demandas dos consumidores, o que significa servir tanto aos propósitos sociais quanto econômicos, dentro de uma perspectiva neoliberal, em consonância com os preceitos da dita sociedade do capital. Esse é o ponto de vista de Ball (1995):

A escolha e o mercado fornecem às classes médias uma forma de reafirmar as suas vantagens reprodutivas na educação, vantagens que têm sido ameaçadas pelo crescente processo social democrático de homogeneização das escolas, pela reforma cultural do currículo (...) e a diversidade de recursos para aqueles estudantes com maiores necessidades de aprendizagem e com maiores dificuldades. A escolha e o mercado reafirmam aqueles privilégios que conferem aos privilegiados 'o supremo privilegio de não se verem como privilegiados. (Bourdieu \& Passeron, 1990:p.210 In: Ball,1995:p.223). 
O que está em jogo quando se propõe discutir as desigualdades conseqüentes de um modelo de sistema pautado na lógica do mercado e na escolha individual - pseudo-escolha se determinada pelas condições de consumo - é analisar as concepções originais de igualdade e liberdade, na sociedade democrática, comparativamente à sua apropriação na sociedade atual. Para tanto, o princípio da meritocracia merece destaque especial.

As expressões "sociedade dualizada" e "sociedade sem cidadãos" são utilizadas por Gentili (1995) na crítica a uma estrutura social fundada no apartheid e na desigualdade de condições. Tendo o princípio do mérito como critério determinante para o acesso individual dos sujeitos-consumidores aos bens e serviços, sejam de que natureza forem estes serviços, este princípio ideologicamente compreendido por "norma de igualdade" passa a ser, justamente, o que vai estabelecer a desigualdade de condições.

O que importa considerar, a despeito das justificativas neoliberais para manutenção da posição da lógica mercadológica no campo da educação, é que seus efeitos acometem uma parcela da população, situando os sujeitos em posições privilegiadas e desprivilegiadas, segundo características étnicas e sociais, o que significa dizer que, recortes de raça e de classe social estabelecem as regras de acesso dos estudantes a um ou outro modelo educacional.

O funcionamento e os efeitos de um mercado da educação beneficiam certas classes e frações de classe em detrimento de outras. Outra vez, o mercado não é neutro. Ele presume certas habilidades, competências e possibilidades materiais (tempo, transporte, creche, etc) que estão desigualmente distribuídas entre a população. (1998: p.215)

Diante da discussão anterior, clarifica-se a inversão do papel da educação impregnada pela lógica do mercado; inversão tendo em vista que acirra a desigualdade social, ao invés de ser direito de todos, de acordo com um projeto social democrático. Estas considerações abrem precedentes para inaugurar as reflexões sobre o cenário no qual se consolidam as políticas afirmativas: $A$ Universidade. É ao que se propõe Borges (2005), no trecho a seguir:

Se a universidade da qual falava Kant, e sobre cuja idéia reflete Derrida, era reservada a um público esclarecido, a universidade contemporânea é uma instituição importante para a democracia, tendo como uma de suas funções a promoção da igualdade social. Por intermédio da universidade, principalmente se for gratuita, setores desfavorecidos econômica ou socialmente podem ter a chance de concorrer igualmente a postos na sociedade, com base apenas no seu mérito. Tal idéia é base do ideal republicano, já expresso nos princípios da Revolução Francesa e atualizado contemporaneamente pelo filósofo John Rawls 
em Uma teoria da justiça, principalmente no princípio de igual oportunidade. (p.168)

Ora, se a educação de base reflete as disparidades provenientes da estrutura capitalista, desenvolta num pensamento político neoliberal, em que posição situa-se a Universidade, levando em conta o que representa enquanto espaço de poder e de ascensão social, não perdendo de vista a função do conhecimento como garantia de poder nas decisões políticas da pólis?

A análise da questão exige certa cautela, põe em relevo uma série de contradições, um convite à reflexão.

Com o intuito de trazer o debate para o âmago da educação superior, é preciso, pois, conhecer os paradigmas que alicerçam a criação destas instituições, trazendo à tona, possivelmente, as raízes que subjazem o processo de democratização das universidades públicas no Brasil. Vale dizer que, a própria expressão processo de democratização das universidades por si própria configura-se paradoxal, se consideramos o papel da Universidade e da educação como formadores de sujeitos sócio-culturais e como veículos de transformação social.

\subsection{Universidade - Gênese e Percursos}

Para uma análise sobre os modelos de educação superior, no sentido de situar em qual deles se encaixaria o caso brasileiro, a divisão em três tipos destes modelos, feita por Peixoto (2011), é conveniente e elucidativa.

Este autor diferencia os sistemas em "de elite, de massa e universalizado" (p.227), cujas definições versam sobre: (a) um sistema voltado para formação de uma classe social dominante, sendo o veículo para garantia de privilégios sociais, tendo o princípio do mérito como condição de acesso; (b) um sistema cuja população atendida origina-se da elite social, econômica e cultural, com a diferença de que atinge entre $16 \%$ e $50 \%$ do grupo cuja faixa etária é compreendida entre 18 a 24 anos, ao passo que o primeiro atinge apenas até $15 \%$ da população; e (c) um sistema com matrículas superiores a $50 \%$ de jovens, "sendo o acesso percebido como uma forma de promoção da justiça social" (Peixoto, 2011, p.227), respectivamente.

O entendimento sobre o modo como a universidade contemporânea se estrutura e das problemáticas enfrentadas por um sistema elitizado que vem percorrendo um percurso de democratização, com esforços de propostas 
políticas de Estado, de iniciativas da sociedade civil organizada e de pesquisas em várias áreas acadêmicas, entre outras ações, exige a retomada dos parâmetros que arregimentaram a criação do ensino superior em âmbitos mundial e nacional. Isto significa uma retrospectiva breve da história da universidade sempre, claro, circunscrita na cena sócio-política nos seus efeitos e percursos históricos.

Se a Universidade Brasileira passa, hoje, por um processo de democratização; sinal de que, nem sempre esteve coerente com os ditames democráticos. Peixoto (2011) constata que:

As primeiras escolas de educação superior começaram a funcionar no Brasil na primeira década do século XIX e, até o início do século XXI, caracterizava-se como um sistema de elite, um sistema voltado para oferecer educação superior como privilégio e para promover os interesses das elites dominantes. (p.228)

A descrição de Peixoto (2011) sobre a estrutura que pautava a constituição do ensino superior no país parece aproximar-se do modelo de ensino superior que baseava as instituições do período entre os séculos XII e XIII, segundo lokoi (2005), as pioneiras. O modelo de funcionamento baseava-se, sobretudo, em relações hierárquicas de poder e nos princípios da meritocracia. Segundo Penin (2004), os primeiros cursos superiores na civilização ocidental tinham por função "cultivar a consciência de uma determinada época". (p.116) (In: Barcellos, 2007)

A Universidade do antigo regime, no seu turno, direcionava-se para formar as elites - "burguesias muito especiais", expressão de Lessa (2004). A lógica meritocrática e a hierarquização são fatores novamente preponderantes e foram ressaltados pelo autor, compondo um espaço: “(...) onde poucos, festejados pela sorte ou pela providência, que ingressassem tinham a possibilidade de ascender às hierarquias disponíveis". (Lessa, 2005: p.33)

Atravessando o período da Revolução Francesa - colocaria a Universidade como uma "instituição a serviço da nação" (p.34) - o advento da Revolução Industrial, segundo Lessa (2005), coloca a Universidade como elemento fundamental, no preparo de indivíduos "letrados" para a organização, o planejamento, a execução de tarefas relativas aos processos de produção, na sociedade econômica.

É no século XIX, através da união de cursos profissionalizantes superiores que surgem, segundo Penin (2004), os primeiros cursos superiores, que na década de 30 funcionavam de modo isolado. Estas primeiras universidades teriam por base os ideais da Universidade do século XII, então atualizados para o século vigente. O Estatuto das Universidades Brasileiras, datado de 1931, contemplam as tendências das universidades no cerne de sua criação: 


\begin{abstract}
Elevar o nível da cultura geral; estimular a investigação científica em quaisquer domínios do conhecimento humano; habilitar ao exercício das atividades que requerem, preparo técnico e científico superior, concorrer, enfim, pela educação do indivíduo e da coletividade, pela harmonia de objetivos entre professores e estudantes e pelo aproveitamento de todas as atividades universitárias, para a grandeza da Nação e para o aperfeiçoamento da humanidade. (p.23)
\end{abstract}

A partir do século XIX, a instituição passa a ser compreendida potencialmente como possibilidade de ascensão econômica e de melhoria nas condições sociais dos vários segmentos da população. Nesse sentido, alia-se ao imperativo de detenção do saber, a necessidade de ampliação do acesso das massas a ela. Nesta conjuntura, a universidade vive o dilema da democratização do ensino superior e da manutenção concomitante de sua excelência.

Isto significa dizer que as universidades brasileiras, as pioneiras, foram criadas com forte tendência elitista, herdada das concepções originárias das instituições burguesas dos séculos XII e XIII, descritas por lokoi (2005); contudo, a época de seu surgimento era, ao mesmo tempo, coincidente com um período de transformação na própria concepção de universidade e de ensino universitário, no sentido de frentes mais democráticas e menos excludentes, verificadas através das reformas de ensino superior na América Latina e Caribe. (Peixoto, 2011)

É preciso compreender, sobretudo, como explica a autora, que essa tendência de expansão de vagas no ensino superior não foi suficiente para que o sistema de elite fosse superado. Alguns aspectos precisam ser considerados: (1). Expansão de vagas não significa democratização do ensino; (2) O sistema privado de ensino foi vetor central no processo de expansão de vagas nas universidades, o que torna este processo peculiar. Uma análise mais pormenorizada do alastramento do setor privado e do sucateamento do setor público no ensino superior, concomitantemente às tendências de democratização neste campo, merece ser realizada.

O trajeto rumo à ampliação do acesso à Universidade preocupa certas instâncias de poder no sentido de ser compatível com a manutenção da excelência acadêmica. Esta questão se intensifica em função do que defende Chauí (2000), quando se remete ao período de "democratização" das Universidades, impulsionado pelas necessidades da economia vigente, à época da atuação dos movimentos estudantis de 1968, na Europa. O processo ocorria concomitantemente às exigências do quadro econômico mundial, compreendidos pela: ampliação do tempo de escolarização com a finalidade maior de impedir que grande parte da mão-de-obra ingressasse no mercado de 
trabalho e ainda, "estabilizando salários e empregos"; alterações na "divisão social do trabalho e no processo do trabalho", culminando na "ampliação dos quadros técnico-administrativos". (p.01) Pode-se notar, portanto, que, atrelado a este "suposto" processo de democratização, emerge uma série de contradições. As contradições mencionadas por Chauí (2000) se justificariam em função da própria lógica do sistema do capital que encontra na desigualdade de condições terreno fértil para manutenção da competitividade e da motivação para o sucesso, na perspectiva do mérito individual. Nas palavras seguintes, três aspectos apontados pela autora merecem consideração:

\begin{abstract}
E primeiro lugar, a ideologia da igualdade educacional revelou seus limites reais, pois a partir do momento em que a maioria adquiriu a possibilidade de receber os estudos superiores, estes perderam sua função seletiva e se separaram de seu eterno corolário, isto é, a promoção social. Se todos podem cursar a universidade, a sociedade capitalista se vê forçada a repor, por meio de mecanismos administrativos e de mercado, os critérios de seleção. Isso implicou, em segundo lugar, a desvalorização dos diplomas, o aviltamento do trabalho e dos salários dos universitários e, finalmente, o puro e simples desemprego. Em terceiro lugar, e como conseqüência, a universidade se mostrou incapaz de produzir uma cultura útil (não fornecendo, na realidade, em emprego nem prestígio), incapaz de funcionalidade, tornando-se um peso morto para o Estado, que passou a limitarIhe recursos. (p.02) (grifo nosso)
\end{abstract}

Penin (2004) relata dados estatísticos que apontam para um aumento substancial do número de estudantes em vários países, desde o período da década de 60 até o atual, aumento também verificado no caso brasileiro. A experiência no país, segundo este autor, traz, como fator marcante, a passagem de uma oferta anteriormente majoritária no poder público para a iniciativa privada de ensino.

Analisando de outra perspectiva a história da democratização da educação em amplitude mundial e em âmbito nacional, cabe mencionar os movimentos sociais e as ações na área de educação no Brasil a partir de Gohn (1992).

Segundo a autora, a educação ganha notória visibilidade na cena política, especialmente na última década do século XX. Acredita - o que se comprova nas críticas de Chauí (2000) -, não se tratar de coincidência o advento de reformas e propostas educacionais de cunho democratizante em momentos de crise econômica e de reconfiguração da cena política, dos seus atores e modelos de acumulação. (p.07). Acontecimentos como o movimento em defesa da escola pública, por volta dos anos 50 , e as reformas propaladas pelo regime militar "preocupadas em adequar a educação brasileira às exigências do novo modo de acumulação associado ao capital internacional" (p.09) - foram exemplos dados 
pela autora para o aparecimento de uma sucessão de medidas educacionais, como estratégias de enfrentamento às crises econômicas.

As décadas de 70 e 80, entretanto, são marcos históricos importantes da evolução de movimentos sociais neste campo. A desorganização, burocratização e queda qualitativa do setor da educação formal, na primeira e o conseqüente surgimento de estratégias no âmbito da educação informal, incluindo experiências não-formalizadas de educação popular, na segunda, inauguram um novo cenário. (Gohn,1992).

$\mathrm{Na}$ década de 90 predomina um misto de descrença na política governamental, uma vez que a sociedade civil organizada começa a tomar consciência da condição de "não-cidadania" que acomete grande parte da população - ainda que a Carta Magna de 1988 re-configure a base jurídicoconstitucional e represente grande avanço do ponto de vista jurídico - e, ao mesmo tempo, faz surgir um conjunto de alternativas, na direção de propostas de educação popular. (Gohn,1992).

Nota-se, portanto, que a época moderna marca um momento de procura crescente pela educação superior. Com o advento da globalização, estas tendências alcançam, numa crescente, o cenário mundial, colocando-se de modos particulares em cada país. (Penin, 2004). Debates e ações propositivas ganham espaço neste momento histórico.

A Conferência Mundial sobre Educação Superior, sediada na UNESCO, em Paris, datada de outubro de 1998, teve grande importância neste cenário, desdobrando e concretizando-se através de um documento intitulado: Declaração Mundial sobre o Ensino Superior para O Século XXI: Visão e Ação. Este documento traz como texto introdutório a visão da Universidade para a nação na contemporaneidade e justifica sua existência, pela necessidade de se refletir coletivamente sobre novos paradigmas e alternativas para solucionar entraves no nível setorial, levando em consideração as peculiaridades dos países. Os seguintes tópicos são postos em pauta: (a) acesso e garantia de condições igualitárias com vistas à formação universitária; (b) manutenção da qualidade do ensino, extensão e pesquisa e (c) acesso equitativo às novas formas e oportunidades de tecnologias em todos os níveis educacionais, entre outros aspectos. (1999).

No que se refere à democratização para a entrada no ensino superior, vale destacar o item 2, artigo 3 - igualdade de acesso, no item $D$, com o seguinte texto: 
Deve-se facilitar ativamente o acesso à educação superior dos membros de alguns grupos específicos, como os povos indígenas, os membros de minorias culturais e linguísticas, de grupos menos favorecidos, de povos que vivem em situação de dominação estrangeira e pessoas portadoras de deficiências, pois estes grupos podem possuir experiências e talentos, tanto individualmente como coletivamente, que são de grande valor para o desenvolvimento das sociedades e nações. Uma assistência material especial e soluções educacionais podem contribuir para superar os obstáculos com os quais estes grupos se defrontam, tanto para o acesso como para a continuidade dos estudos na educação superior $(1999$, p.22)

Vale ainda mencionar o trecho contido no item primeiro, artigo 1 - A missão de educar, formar e realizar pesquisas:

As missões e valores fundamentais da educação superior(...) devem ser preservados, reforçados e expandidos ainda mais, a fim de (...) d) contribuir para a compreensão, interpretação, preservação, reforço, fomento e difusão das culturas nacionais e regionais, internacionais e históricas, em um contexto de pluralismo e diversidade cultural. (p.29)

Dentre os objetivos da educação superior, acima mencionados, há que se dar especial atenção à referência feita na busca de "um contexto de pluralismo e diversidade cultural" (p.29). A referência remete ao conceito de multiculturalismo, pautado na "(...) defesa da pluralidade cultural, no respeito e no reconhecimento das diferenças culturais", que, explica Igreja (2005), teria estreita relação com o debate sobre políticas de ação afirmativa no contexto brasileiro. É nesta perspectiva que se situa o Relatório Mundial sobre o Desenvolvimento Humano, datado de 2004, com divulgação do Programa das Nações Unidas para o Desenvolvimento (PNUD) pressupondo as políticas multiculturalistas, segundo a autora, como única possibilidade de "promover o respeito e a proteção da diversidade e do pluralismo, ameaçados pelos processos de Globalização". (p.35) Analisemos as vestes do movimento, os desdobramentos políticos para o processo de consolidação das ações afirmativas no Brasil e as controvérsias geradas no diálogo frente aos diferentes posicionamentos sobre o tema.

\subsection{Multiculturalismo e Educação: Pressupostos e Dilemas}

O papel decisivo dos meios de comunicação na construção de conhecimentos relativos à raça e etnicidade não tem sido suficientemente enfatizado. Investigações, entretanto, demonstram o impacto sobre os leitores, telespectadores, ouvintes da etnia dos apresentadores e personagens, levando-os a reforçar ou negar valores, a construir relações in-terétnicas positivas, ou não. Isso tem sérias repercussões na escola e nos propósitos de educação multicultural, pois alunos e pais, professores e outros profissionais em exercício nas escolas estão expostos à mídia. (Gonçalves e Gonçalves e Silva, 2006: p.13) 
Conceituar o movimento multicultural de forma unívoca seria inapropriado. Compreendê-lo exigiria, sobretudo, uma análise sócio-histórica e política dos contextos nos quais o movimento ganha escopo. Gonçalves \& Gonçalves e Silva (2006) partem dessa premissa e propõem, antes de estabelecer definições, refletir sobre os princípios e ações que norteiam o movimento a partir dos formatos e direções tomadas por seus atores nos contextos de sua consolidação e, conhecer a pluralidade de significações atribuídas às experiências de caráter multicultural.

As posições frente a tais tendências são divergentes, asseguram os autores. De um lado os que consideram "uma política ingênua e leviana", de outro, aqueles que o defendem, apostando ser "uma estratégia política de integração social" (2006: p.12). A impossibilidade de estabelecer parâmetros únicos de definição do movimento se agrava quando se considera a polissemia do termo assumida em contextos variados, uma vez que os povos diferem-se quanto às culturas, histórias e organização social.

É ainda Gonçalves e Gonçalves e Silva (2006) que situam a origem do movimento multicultural em amplitude mundial na mobilização de grupos "culturalmente dominados" (p.17) no sentido de reversão de uma lógica que privilegia determinadas culturas em detrimento de outras. De acordo com estes autores: "contam com a aliança de outras minorias ou de grupos culturalmente dominados e, juntos, reagem por meio de suas organizações políticas, para serem reconhecidos e respeitados quanto aos seus direitos civis." (p.17)

Candau (2008), analisando as várias facetas e abordagens do movimento, afirma que a história do continente americano é marcada por relações interétnicas, por processos de construção de identidade e subjetividades pautadas em relações de poder assimétricas, de subordinação e excludentes. Segue trecho em que esse ponto de vista fica evidente:

A nossa formação histórica está marcada pela eliminação física do outro ou por sua escravização, que também é uma forma violenta de negação de sua alteridade. Os processos de negação do outro também se dão no plano das representações e no imaginário social. Neste sentido, o debate multicultural na América Latina nos coloca diante da nossa própria formação socioculturalmente, o que negamos e silenciamos, o que afirmamos, valorizamos e integramos na cultura hegemônica. (p.17)

Dentre as possíveis tendências relacionadas ao multiculturalismo, vale as elencadas por Almeida (2003) e Moreira (2001), a seguir: "(1) Atitude a ser desenvolvida em relação à pluralidade cultural; (2) meta a ser alcançada em um determinado espaço social; (3) estratégia política referente ao reconhecimento 
da pluralidade cultural; (4) corpo teórico de conhecimentos que buscam entender a realidade cultural contemporânea; (5) caráter atual das sociedades ocidentais". (p.15)

As perspectivas descritiva e propositiva dividem os posicionamentos diante das significações do termo multiculturalismo, segundo Candau (2008). O primeiro inclui uma linha de pensamento que compreende o movimento como parte das conjunturas e organizações sociais contemporâneas. Este modo de entendimento implica em considerar que "vivemos em sociedades multiculturais" e ainda que "as configurações multiculturais dependem de cada contexto histórico, político e sociocultural" (p.19). A dimensão propositiva do termo remete, por sua vez, à associação do movimento multicultural a um projeto político-cultural, "uma maneira de atuar, de intervir, de sociedade, de conceber políticas públicas na perspectiva da radicalização da democracia, assim como de construir estratégias pedagógicas nesta perspectiva." (p.20)

Em síntese, é ainda Candau (2008) que situa o multiculturalismo em duas correntes de pensamento na cena atual: aquela que privilegia a integração dos diferentes grupos, vislumbrando a constituição de uma cultura homogênea, comum, hegemônica - abordagem denominada assimilacionista - e a que tem por princípios básicos "o reconhecimento das diferenças" e a impossibilidade de que haja integração entre grupos étnicos e culturais distintos concomitantemente à garantia da preservação das identidades e heterogeneidades - abordagem do tipo diferencialista.

Nem assimilacionista, tampouco diferencialista. Candau (2008) defende, sobretudo, a articulação das políticas de igualdade com as políticas de identidade confluindo na corrente interculturalista. Eis as argumentações em sua defesa:

\footnotetext{
Promover uma educação para o reconhecimento do 'outro', para o diálogo entre os diferentes grupos sociais e culturais. Uma educação para a negociação cultural, que enfrenta os conflitos provocados pela assimetria de poder entre os diferentes grupos socioculturais nas nossas sociedades e é capaz de favorecer a construção de um projeto comum, pelo qual as diferenças sejam dialeticamente incluídas. (p.23)
}

O movimento multiculturalista no Brasil tem se fortalecido e, ao mesmo tempo, sido alvo de divergências envolvendo a sociedade civil, mídia, organizações sociais, academia, justiça, entre outros.

Grupos sociais que ao longo da historia foram impedidos de usufruir dos direitos básicos e oportunidades, situando-se em posições subalternas na hierarquia social - caso das mulheres, homossexuais, negros - reivindicam 
espaços nas decisões políticas da polis, visibilidade, igualdade de condições e o direito à diferença.

A resistência e mobilização política do movimento multicultural no país foram desencadeadas por segmentos socialmente desfavorecidos da população.

As discussões e embates a respeito do tema têm ganhado relevo na cena contemporânea, sobretudo na área da educação. A relevância da aproximação entre o movimento e o campo educacional deve-se ao estreitamento entre os elementos educação e cultura, expresso dos termos: “(...) não há educação que não esteja imersa nos processos culturais do contexto em que se situa. Neste sentido, não é possível conceber uma experiência pedagógica "desculturalizada", isto é, desvinculada totalmente das questões culturais da sociedade" (p.13)

Embora se articulem diretamente 0 surgimento de correntes multiculturalistas e a implementação de ações afirmativas, no Brasil em específico, as idéias multiculturais se disseminaram em grande parte no país impulsionadas pelo movimento negro brasileiro, cuja aproximação com organizações negras estrangeiras trouxe para a agenda de pautas do movimento novas estratégias de mobilização social, focalizando como objetivo, dentre outros, a derrubada do chamado mito da democracia racial no país, além de mudanças de paradigmas e representações sociais que cristalizam estereótipos de inferioridade da raça negra em contraposição ao enaltecimento da raça branca.

O fortalecimento do movimento multicultural no Brasil, diz Gonçalves e Gonçalves e Silva (2006), dependia, mais do que afirmar e projetar a cultura negra de modo positivo social e politicamente, da aniquilação de certo "complexo de inferioridade" da população afrodescendente contribuindo, em contrapartida, para afirmação de uma identidade negra.

Verifica-se, em suma, que as ações afirmativas têm relação com tendências multiculturais, sendo a política de reserva de vagas nas universidades uma das ações dentro de um conjunto de medidas, sejam elas legitimadas pelo Estado, sejam impulsionadas por iniciativas da sociedade civil organizada. É notório, também que, tangenciando o tema das "cotas" - como é vulgarmente conhecida - encontram-se uma variedade de outros temas, alguns já em discussão em variados espaços, outros postos em discussão a partir da implementação da política de reserva de vagas nas universidades de todo país. No ato de analisar a política propriamente dita, analisar-se-ão essas temáticas 
que a tangenciam. Ao próximo item competirá refletir sobre elas a partir das questões que a experiência faz deflagrar.

\subsection{Ações Afirmativas e Educação Superior no Brasil: Expansão e/ou Democratização?}

A análise da experiência de reserva de vagas no ensino superior brasileiro está atrelada, inexoravelmente, a dois pontos: o primeiro deles centra-se na compreensão do significado da expressão ação afirmativa, nas suas propostas e fundamentações e o segundo, mas de igual relevância, das relações estabelecidas entre Políticas de Estado e Ações da Sociedade Civil no que se refere às questões sociais e políticas do país.

Façamos uma reflexão, a partir das considerações de Vieira (2003):

Devemos observar que as ações afirmativas diferem em sua natureza: creio que devemos considerá-las tanto como políticas de ação afirmativa (emanadas do Estado e das diversas instituições e instâncias governamentais), quanto como iniciativas de ação afirmativa (criadas sobretudo pelas diversas formas de organização da sociedade civil) (...) Ao promovermos essa cisão, uma dicotomia expressa pela relação estado/sociedade evidencia-se e, a partir desse ponto, acredito que possamos investir em uma observação mais atenta das ações afirmativas dentro do contexto das políticas sociais (p.89)

Vieira (2001) situa o conceito de "ação afirmativa" no cerne do aspecto sócio-político de suas experiências. Logo, pode-se compreendê-las tanto enquanto medidas implementadas pelo Estado, quanto por iniciativas tendo por autores/executores a sociedade civil organizada. Ambos, Estado e Sociedade Civil, estabelecem - melhor seria dizer - uma relação dialética, em que os atores micro e macropolíticos consistem em dispositivos de ação que intervém de maneira imbricada, co-relacionada.

A presente pesquisa parte de um destes pólos de intervenção: as políticas de reserva de vagas consistem em Políticas Públicas de Estado. Levando em conta a dimensão dialética e o equívoco em tomar as ações políticas de forma isolada, resta, como única saída, refletir sobre estas políticas compreendendo-as a partir das relações estabelecidas com os demais atores sociais e políticos em jogo.

Não é sem sentido que pesquisadores ressaltam a aproximação entre as ações afirmativas no Brasil e as experiências pioneiras destas propostas em outros países, nos EUA, em específico. A influência da experiência norteamericana na promoção de propostas semelhantes em outros países deve ser 
considerada, não somente no Brasil, mas em outros países. Entretanto, as particularidades desta experiência no nosso país exigem atenção por vários motivos, a começar pelas mudanças nas concepções do termo cidadania, perpassando práticas dos movimentos sociais organizados - em destaque o movimento negro - culminando na efetivação de propostas políticas estatais impulsionadas, sobretudo, por ações da própria sociedade civil, protagonistas destes e de outros movimentos sociais organizados, em destaque os cursos prévestibulares comunitários.

(...) Embora haja um debate governamental acerca do tema (e de fato, levantamentos feitos apontam para uma paridade entre iniciativas da sociedade civil e as governamentais), sua efetivação, a princípio, somente foi levada adiante pela iniciativa civil, sobretudo na realização de cursos pré-vestibulares. (Vieira, 2003, p.89)

A análise a respeito da política de reserva de vagas no ensino superior no Brasil remete necessariamente, como bem destaca Vieira (2003), à participação de ações sociais organizadas, como os cursos pré-vestibulares comunitários, acima mencionados. Neste sentido, são de grande contribuição as palavras de Candau (2003) quando propõe analisar as "ações afirmativas" sob duas perspectivas, uma mais restrita e outra mais abrangente.

\begin{abstract}
No primeiro caso, as ações afirmativas são apontadas como políticas públicas temporárias, promovidas por parte do Estado, tanto em Poder Legislativo quanto no Executivo, que objetivam a promoção da igualdade entre os grupos sociais, levando em consideração desvantagens sofridas ao longo da história, como aponta Melo (1998) (...) A segunda possibilidade de concepção e desenvolvimento das ações afirmativas seria encará-las como medidas amplas, não necessariamente atreladas às políticas públicas, medidas estas que visam à justiça distributiva, ou seja, que buscam a democratização da sociedade e são promovidas em diferentes espaços sociais. (Candau, 2003, p.91/92)
\end{abstract}

De acordo com a autora, a política de reserva de vagas nas universidades - vulgarmente conhecida como política de cotas - se enquadraria nas primeiras enquanto os movimentos atrelados aos cursos pré-vestibulares comunitários, no segundo grupo. Ainda podem ser incluídas, neste último, quaisquer medidas institucionais com vistas a possibilitar condições mais equânimes no que se referem às oportunidades educacionais, não exclusivamente restritas ao acesso, mas às que intervém, também, no próprio processo de formação de sujeitos sócio-politicamente ativos, seja do ponto de vista individual, seja coletivamente. (1993, p.92)

Vieira (2003) reitera a importância de compreender as ações afirmativas a partir das relações entre as duas perspectivas citadas por Candau (2003), 
distinguindo o caso Brasileiro de outros países, sobretudo os EUA. Segundo esta autora, o que marca a história brasileira é justamente o fato de que, mesmo tendo sido legitimada pelo Estado sob o viés de política pública, as políticas de reserva de vagas contaram fundamentalmente com a pressão feita pelos movimentos sociais, em especial o movimento negro, ao que Vieira (2003) atribui ao surgimento de uma nova sociedade civil, "atuante, organizada politicamente" (p.90), fazendo emergir novas concepções de cidadania e modos de participação social.

Em se tratando de uma comparação com a experiência nos demais países, a experiência no Brasil guarda particularidades. É o que fica explícito em Vieira (2003):

Tanto nos Estados Unidos como na África do Sul, ou nos demais países com experiências de ação afirmativa, a pressão dos movimentos anti-racistas obrigou o Estado a assumir o monopólio do combate oficial das desigualdades raciais. Ou seja, as ações afirmativas, desde cedo, configuram-se como política social, e mesmo aquelas, inativas desenvolvidas pela sociedade civil, as chamadas voluntary affirmative action, posicionavam-se sob as determinações do Estado. (p.90) No Brasil, desde as décadas de 60/70, o movimento negro vem discutindo a relevância das ações afirmativas e organizando-se politicamente para pressionar sua adoção, contudo, o Estado Brasileiro mostrava-se reticente até mesmo com relação a aceitar oficialmente a existência do racismo. (p.90)

Neste sentido, conclui a autora:

Diante deste painel, aparentemente intransponível, nas últimas décadas, ações afirmativas tomaram corpo no seio da sociedade civil, com recursos próprios e à margem do controle estatal, o que, em um limite, dá às várias experiências brasileiras de ação afirmativa perfis e características totalmente diferenciados, permitindo, inclusive, em alguns casos, o hibridismo entre desigualdade racial e social, expresso pela categoria carente, utilizada por várias iniciativas. (p.90)

Tomando as considerações de Vieira (2003) como ponto de partida, salientam-se duas iniciativas emblemáticas desta "sociedade civil atuante" brasileira, quais sejam: Os cursos pré-vestibulares comunitários e o movimento negro.

Para analisar o escopo que embasa tais movimentos, nas ideologias, perspectivas e propostas de ação, será preciso retomar algumas discussões como é o caso do percurso histórico da democratização do ensino superior brasileiro, nas últimas tendências; dos conceitos de cidadania e participação social, reconfigurados fazendo surgir um novo cenário sócio-político e; por fim, das tendências multiculturais cujos rumores exercem influência e justificam ações do movimento negro e políticas públicas voltadas para a população afro- 
descendente, dentre as quais se encontra a política de reserva de vagas com recorte racial.

A respeito das características que marcaram os processos de ampliação e de democratização do ensino superior ${ }^{1}$, Dias Sobrinho (2011) referencia o fenômeno da globalização e seus efeitos na educação brasileira:

O aumento da demanda por estudos superiores se tornou um imperativo da sociedade atual, determinada fortemente pela economia globalizada. Em razão da incapacidade de o estado prover adequadamente o sistema com fundos públicos, de modo a atender a explosiva demanda, se incrementou a política de expansão da oferta por meio da iniciativa privada.(...)" (p.139)

Tratando o tema mais detidamente, o autor destaca alguns aspectos importantes neste processo, dentre os quais se destacam dois: O primeiro seria "a explosão da quantidade das matrículas e das instituições nos últimos anos, especialmente por via privada (...)" e o segundo, "a insuficiência do financiamento público e diversificação financeira (...)", já que, "A impossibilidade de o Estado prover a educação para todos obriga as instituições a competirem por alunos e por recursos financeiros de diversas fontes públicas e privadas; (...)" (p.139/140)

Estas discussões já foram melhor analisadas em momento anterior. Por ora, contribuem para constatar que as políticas públicas para educação superior estão entremeadas às políticas no âmbito privado, complexificando ainda mais o entendimento das experiências de ações afirmativas no Brasil, uma vez que se fazem com contradições e embates, principalmente se considerarmos que as linhas divisórias entre público e privado tendem ao arrefecimento. As palavras de Dias Sobrinho (2003) são esclarecedoras neste sentido:

\begin{abstract}
"Estes fatores que fazem parte das transformações e das novas problemáticas educacionais, num quadro de crescente complexidade da sociedade - indicam que as categorias tradicionais e opostas do público e do privado já não servem muito bem para explicar o sistema de educação superior. Entre público e privado não há mais fronteiras bem definidas e incomunicáveis. (...) o poder público impulsiona programas que ampliam o acesso às instituições privadas e públicas. Surgem os programas de subsídios diretos e indiretos, por via de renúncia fiscal, ações afirmativas consignadas em cotas ou bônus." (p.140)
\end{abstract}

Do ponto de vista histórico-político, Gomes et alli (2011) analisa as políticas para educação superior, tanto públicas quanto privadas, no transcorrer dos processos de gestão referentes aos anos de 1995-2002 - governo Fernando Henrique Cardoso e 2003-2008 - governo Luiz Inácio Lula da Silva.

\footnotetext{
${ }^{1}$ É preciso distinguir democratização de ampliação de vagas.
} 
Estes autores (2011) consideram que, no primeiro período, prevaleceram políticas, programas e ações estatais em Instituições de Ensino Superior (IES) privadas. (p.154) Entendem ainda que, tais iniciativas desencadearam efeitos inesperados para as instituições públicas de ensino. Três eixos marcam este período: "flexibilidade, competitividade e avaliação" (p.154). Os dois últimos competitividade e avaliação - sugerem um processo focado na mercantilização da educação com conseqüente instituição de processos de avaliação, em destaque o Exame Nacional de Cursos - Provão. Estes autores avaliam esta medida nos seguintes termos:

O Exame Nacional de Cursos (Provão), exame criado em 1995, ocupou papel central, uma vez que permitiu o estabelecimento de ranking entre as IES e cursos, baseado exclusivamente em uma prova (exame) aplicada aos formandos dos diferentes cursos de graduação. Na prática, o pretenso sistema de avaliação indicava uma mudança substancial no papel do Estado que, se por um lado, liberou o crescimento pela via privada, por outro passou a informar a qualidade dos produtos acadêmicos aos consumidores, fazendo ameaças de fechamento de cursos e instituições, sem, contudo, efetivá-las, quando a má qualidade era aferida nos cursos por meio do provão. (p.155)

No período seguinte (2003-2006 - Governo Lula), os autores salientam continuidades e mudanças. A preocupação com os rumos das universidades públicas, especialmente no seu papel de transformação e de garantia de justiça social, esteve na pauta de ações do governo. Duas ações iniciais foram citadas: A designação da Comissão Especial de Avaliação, composta por intelectuais comprometidos com a temática (p.166), partindo do princípio de que

A educação é um direito e um bem público, entende que a missão pública da educação superior é formar cidadãos, profissional e cientificamente competentes e, ao mesmo tempo, comprometidos com o projeto social do país. (Brasil, MEC, 2003, p.7)

E o segundo - O Sistema de Avaliação da Educação Superior (SINAES) -, com as seguintes diretrizes:

Educação como direito social e dever do Estado; definição de valores sociais historicamente determinados; rediscussão dos atuais marcos de regulação e controle ampliando o seu escopo para o Estado e a comunidade educativa; resgate histórico e político do caráter educativo e, portanto, formativo da avaliação; respeito à identidade e à diversidade institucionais, em um sistema diversificado e globalidade (...), dentre outros.(p.167)

Logicamente, e compreensível, que haviam expectativas dos movimentos sociais que apoiaram a ascensão da proposta política de governo em questão, segundo enfatiza Gomes ett alli (2011,p.168), de que este governo desse conta 
de obstaculizar os rumos privatistas da educação superior no país, de modo que o sistema de elite que até então vigorava no Brasil, fosse substituído por um sistema de massa, especialmente no setor público eram muitas.

Em que pesem os efeitos produzidos e os possíveis pontos de vista sobre o tema, aqui importa mais tomar conhecimento das ações políticas mais determinantes no processo de ampliação/democratização do ensino superior, tanto na iniciativa privada quanto no âmbito público. As principais, conforme os autores: "SINAES, PROUNI, ampliação do FIES, REUNI, o projeto de Reforma da Educação Superior em tramitação no Congresso Nacional (PL. n7200/2006)" (p.169)

Referentes ao setor privado, o PROUNI e o FIES foram os projetos mais significativos. Seguem abaixo as finalidades das duas propostas:

O PROUNI, criado pela Medida Provisória n.213/2004 e institucionalizado pela Lei n11096 (BRASIL, 2005), tem como finalidade conceber bolsas de estudos integrais e parciais a estudantes de baixa renda, em cursos de graduação e seqüenciais de formação específica, em instituições filantrópicas e privadas de educação superior (OLIVEIRA, 2007 in: Gomes ett alli, 2011, p.173)

O FIES, por sua vez, foi criado em 2001, no governo FHC, para substituir o Programa de Crédito Educativo - PCE/CREDUC (Brasil,2001b) (...) Desde o processo seletivo do segundo semestre de 2008 , o FIES passou a financiar até $100 \%$ do valor da mensalidade. A parte não financiada passou a ser paga pelo aluno diretamente à instituição de ensino. (p.174)

No que implica em sinalizar as iniciativas no setor público, é notório:

O programa de expansão e interiorização das IFES; o programa de apoio a planos de reestruturação e expansão das Universidades Federais (REUNI); a criação do sistema Universidade Aberta do Brasil (UAB) e o processo de integração de Instituições Federais de Educação Tecnológica, para a constituição dos institutos federais de educação, ciência e tecnologia (IFETs), no âmbito da rede federal de educação tecnológica. (...).

No conjunto das ações na rede pública, encontram-se as políticas de reservas de vagas para educação superior, propriamente ditas, com recortes sociais e/ou raciais, bem como outras políticas de ações afirmativas, a serem melhor discutidas no decorrer deste trabalho.

Longe de pretender analisar detidamente todos estes programas, esta reflexão - com ênfase no papel e nas ações do Estado na educação superior brasileira nas gestões de governo mais recentes - serve para situar a política de reserva de vagas num conjunto mais amplo de Políticas de Estado, focando, no caso brasileiro, as interfaces e contradições provenientes de sua implementação, tendo em vista o dilaceramento das fronteiras entre público e privado, dentre outros fatores. 
Em meio a turbulências tensionadas a partir da relação com o Estado e com outros segmentos sociais e concomitantemente às ações do Estado concernentes a um projeto político de governo, nas suas continuidades e rupturas, a sociedade civil organizada age no sentido de reivindicar e fazer valer direitos, impulsionada por interesses e convicções ideológicas pessoais e coletivas. Verifiquemos as ações destes movimentos nas tensões/articulações com as demais esferas políticas de ação.

\subsection{Os cursos pré-vestibulares comunitários e a PUC-Rio: A experiência do Programa de Ação Social}

Aproveitando as ponderações anteriores - as relações entre público e privado no cerne das políticas de expansão da educação superior e a história das ações afirmativas no país, pondo em confronto e, ao mesmo tempo, lado a lado, movimentos sociais e políticas de governo -, toma a vez um projeto, antecedente ao PROUNI, com menor repercussão e proporção, ocorrido, pontualmente, em uma instituição privada de ensino superior da cidade do Rio de Janeiro: O Programa Bolsa de Ação Social da PUC-Rió2. Implementado em 1994 em função da parceria entre os cursos pré-vestibulares comunitários e esta Universidade - Católica, filantrópica, com maioria do corpo discente proveniente das camadas mais favorecidas da população do Rio de Janeiro - a experiência, pioneira à época, traz reflexões importantes, sobretudo em razão do pioneirismo da proposta e, em conseqüência, dos desafios enfrentados.

A proposta põe em análise, entre outras problemáticas, as contradições de um sistema de ensino superior que privilegia um tipo específico de alunado e os processos de exclusão/inclusão social resultantes de um sistema baseado no consumo e que produz uma sociedade apartada. São muitas as questões que subjazem desta experiência. Será dado privilégio, aqui, às tensões entre as ideologias que sustentam os movimentos pré-vestibulares comunitários - sem perder de vista a heterogeneidade do movimento, haja vista as diferenças nas propostas e nos aspectos ideológicos a eles inerentes - e um processo de democratização/expansão que concilia instituições tanto de âmbito público quanto privado, como é o caso brasileiro.

\footnotetext{
${ }^{2}$ Este projeto foi tema de investigação e análise para elaboração da dissertação de mestrado intitulada "jovens de pré-vestibulares comunitários na PUC-Rio, experiências e táticas no convívio com a alteridade" defendida no departamento de pós-graduação em psicologia da PUC-Rio, de minha autoria e sob orientação de Solange Jobim e Souza. Para maiores informações, ver referência: Barcellos, 2007.
} 
O programa de ação social da PUC-Rio enfrentou inúmeras barreiras, desde a inclusão dos jovens de esferas sociais menos privilegiadas numa universidade privada voltada para o público majoritariamente mais elitizado, até questões relativas à permanência destes jovens na instituição. $O$ processo seletivo do vestibular era o mesmo dos demais alunos, mas a manutenção destes estudantes dependia tanto da bolsa integral da mensalidade - concedida mediante a vinculação a algum curso pré-vestibular comunitário previamente cadastrado pela instituição - quanto do Fundo Emergencial de Solidariedade $(\text { FESP })^{3}$ - criado pela Pastoral da PUC-Rio, contando com doações para auxiliar os estudantes nos custos indiretos da formação acadêmica, como transporte, alimentação, material didático.

O Fundo Emergencial de Solidariedade (FESP) foi idealizado a partir das demandas de situações cotidianas envolvendo os primeiros estudantes que ingressaram via Programa de Ação Social. Na pesquisa, relatos apontam grande evasão destes alunos e situações-limite por falta de recursos básicos, principalmente referentes ao transporte e à alimentação.

A princípio a Pastoral, responsável pela administração/distribuição do FESP, atendia um número reduzido de estudantes. Entretanto, o crescimento do projeto trouxe também o aumento dos problemas a serem enfrentados, tendo em vista a grande proporção de estudantes de baixa renda desprovidos de recursos para permanecerem no ensino superior. Uma proposta-piloto, contando com um Fundo de Emergência como política de permanência, não daria conta, obviamente, do contingente de problemas desta ordem. Os atores institucionais, idealizadores do projeto, deram-se conta deste fato na medida da experiência concreta de sua implementação. Compreensível. Entretanto, interessantes foram as controvérsias geradas em razão da incompatibilidade entre as filosofias dos cursos pré-vestibulares comunitários - enquanto movimentos sociais com ideologias e posições políticas que superavam o ingresso de estudantes de camadas populares na universidade - e as medidas internas institucionais de enfrentamento destas problemáticas, próprias de uma instituição de ensino com as características da PUC-Rio 4 .

O crescimento do número de jovens, atendidos pelo FESP, promoveu alguns outros impactos que passaram a ser motivos de preocupação por parte da equipe da Pastoral. Com o crescimento do projeto e levando em conta a rede

\footnotetext{
${ }^{4} \mathrm{FESP}=$ fundo emergencial de solidariedade. Verba adquirida através de doações com vistas a custear os gastos dos estudantes bolsistas com transporte, alimentação.

${ }^{4}$ Privada, Filantrópica, Católica.
} 
social e de comunicação entre os integrantes dos pré-vestibulares comunitários e, mais ainda, tendo conhecimento de que a grande maioria dos jovens que ingressavam naquela universidade, oriundos destes cursos, mantinha-se a eles vinculados lecionando voluntariamente, mesmo que nos primeiros anos da universidade, a possibilidade de obtenção do auxílio tornou-se muitas vezes determinante na escolha da PUC em detrimento das demais universidades, especialmente as públicas, tão almejadas por muitos até então. Em meio a este contexto, idealizadores do Programa de Ação Social deparam-se com um quadro de "inchaço" de jovens e, em contrapartida, com a impossibilidade da Universidade de absorver todo esse contingente nos projetos, tanto das bolsas quanto dos auxílios.

Alguns depoimentos revelaram que os próprios integrantes dos cursos prévestibulares comunitários estariam orientando seus estudantes a optarem pela PUC, sabendo da existência do Projeto de Ação Social. A infra-estrutura da universidade e a não-ocorrência de greves freqüentes por parte de seus funcionários, aliadas à possibilidade de bolsas integrais e de auxílio-alimentação, transporte e outros, constituíram um conjunto de fatores determinantes na escolha pela PUC-Rio.

$\mathrm{Na}$ linha de interseção entre a atuação dos pré-vestibulares comunitários e a da PUC-Rio junto a estes jovens, a equipe da Pastoral notou mudanças nas formas dos jovens se relacionarem com este segmento institucional e na maneira de compreender o que a equipe da Pastoral procurava chamar de FESP. Viam o auxílio como um "benefício" que estava sendo proporcionado por solidariedade de pessoas sensibilizadas com a causa. Esta também era a visão da Pastoral e, portanto, o que seus integrantes tentavam passar para os jovens que entravam na instituição à época.

Após ter participado de uma destas reuniões para alunos recém-chegados na PUC em busca do FESP, pude constatar alguns jovens com colocações e posicionamentos de certa forma incisivos, reivindicatórios, no sentido de cobrança de um direito adquirido. Assim, clarifica-se o dilema que assolava a equipe em torno das direções para onde caminhava o Projeto: "FESP: sinônimo de benefício" ou "FESP: sinônimo de direito"? A preocupação da posição de um dos integrantes da equipe da Pastoral, expressa no trecho a seguir, reflete o momento ${ }^{5}$ :

\footnotetext{
${ }^{5}$ Os depoimentos aqui apresentados foram extraídos do trabalho de dissertação de mestrado de minha autoria intitulado jovens de pré-vestibulares comunitários da PUC-Rio: experiências de táticas no convívio com a alteridade, já mencionado. Para tanto, foram realizadas entrevistas com
} 
Por mais que a gente coloque: 'é um benefício, não é um direito!', ainda têm muitos... identifiquei isso muito nos que vêm dos pré-vestibulares comunitários. Acho legal eles, até certo ponto, colocarem um pouco isso, porque eles têm na preparação deles, no programa, pelo menos de alguns que eu conheço, uma matéria que eles chamam cidadania, que é um pouco pra sacudir mesmo, pra dizer: 'olha! Vá a luta, o Estado também é seu, ainda é uma elite que está na universidade na nossa realidade brasileira, você tem direito a este espaço"' Então, eu sinto que eles chegam dizendo: 'olha, já que eu estou aqui, eu tenho direito!' E aí, há uma dívida social que eles cobram, e cobram da gente que representa a sociedade pra eles, que no momento está aqui, resgatando essa divida com eles. Por outro lado, aí o que a gente faz? A gente trabalha com eles isso: olha o projeto, o que vocês vão receber é um benefício, uma ajuda. Não é um direito. Alguém tá financiando. É fruto de solidariedade de algumas pessoas... $30 \%$ dos recursos ainda são muito instáveis, porque tenta botar o mais transparente possivel pra eles isso: 'Olha, os recursos que a gente tem são esses aqui, então a gente recebe pra redistribuir pra vocês. Não é um direito, ainda não. (El/3) (Barcellos, 2007, p.72/73)

O percurso dos jovens como estudantes da PUC teve início antes mesmo de do momento correspondente à entrada nesta instituição, em função das suas expectativas e anseios de ingresso em um espaço desconhecido, "estrangeiro". Assim sendo, de antemão, a apreensão de uma sensação de estrangeirismo acometeu a maioria deles. Os relatos trazidos nas entrevistas corroboram esta assertiva. Dentre os vários sentimentos de apreensão, alguns se relacionavam à discussão presente. Vejamos as razões:

Em se tratando do momento antecedente à entrada na PUC (quando recebem a notícia do vestibular), o primeiro aspecto que distingue as experiências dos jovens refere-se ao sentimento de cada um em relação à própria PUC, isto é, ao significado que o fato de ser estudante da PUC teria na vida de cada um deles. (Barcellos, 2007, p.117)

O sonho de entrar na Universidade foi o maior motivador de todo o esforço realizado e a aprovação no vestibular significaria, para todos, a realização deste sonho. Entretanto, "ir pra PUC" trazia significados distintos para cada um dos jovens. Alguns comentavam que, já na preparação para o vestibular, tinham como alvo principal esta instituição, quase todos atraídos pela grande infraestrutura da universidade, aliada à possibilidade de não perderem dias letivos por conta de greves que comumente ocorrem nas universidades públicas brasileiras. Alguns tomaram conhecimento, previamente, da possibilidade de receberem auxílios transporte e alimentação através do projeto do FESP.

atores institucionais idealizadores do projeto, dentre eles, professores, administradores da vicecomunitária, e integrantes da equipe da Pastoral, responsável pela administração do Fundo emergencial de solidariedade - FESP, aqui referido, dentre outros entrevistados. (ver referencia Barcellos, 2007). Também foram realizadas entrevistas com os jovens estudantes da PUC-Rio, à época, e integrantes do programa de ação social aqui mencionado. Suas identidades estão preservadas tanto na referencia de origem quanto neste trabalho. El/3, sigla situada ao lado da fala em destaque representa: "entrevistado 3". 
Para outro grupo de jovens, os dois acontecimentos (o de ter sido aprovado e o de ser aluno da PUC), não tinham o mesmo significado. Ao mesmo tempo em que comemoravam a aprovação no vestibular, sentiam-se frustrados por não estarem indo para uma universidade pública. Para estes estudantes, o sonho de conquistar uma vaga no ensino superior coincidia, necessariamente, com o sonho de ser estudante de uma instituição pública. As razões seriam muitas $^{6}$.

Alguns dos estudantes compartilhavam de uma ideologia de transformação social e política, através da democratização do ensino superior, de modo que as vagas das Universidades (que são gratuitas e que deveriam ser para todos), passassem a ser ocupadas também pelos estudantes das classes sociais populares. Além disso, outro motivo seria também o fato de terem que adentrar num espaço cuja maioria de alunos pertenceria a uma 'elite econômica'. O status de ter sido aprovado no vestibular e de fazer parte da universidade pública ainda é, para muitos, sinônimo de sucesso. A diversidade sócio-econômica, presente no corpo discente das instituições públicas, ainda é maior do que nas universidades particulares, ainda que isto não se confirme no caso de alguns cursos de maior procura. Contudo, alguns dos jovens chegaram a comentar sobre o quanto sonhavam em fazer parte dos movimentos políticos que acontecem na Universidade Pública, das reivindicações por uma universidade democrática e igualitária. Nestes casos, ser estudante de uma universidade pública significaria a possibilidade de um espaço de militância, dando continuidade ao que praticavam nos cursos pré-vestibulares comunitários dos quais alguns deles faziam parte.

Em se tratando da influência destes cursos pré-vestibulares na escolha dos estudantes para as públicas ou para a $\mathrm{PUC}^{7}$, os casos variavam. Embora tenha sido constatado, nos casos mais recentes, o incentivo destes cursos para que seus alunos procurassem a PUC (em razão da possibilidade de atendimento pelo FESP), em contrapartida, outros cursos incentivariam os alunos a cursar o ensino superior público, neste caso, motivados por uma ideologia política. Houve o caso de, no próprio curso pré-vestibular, ocorrer uma diferenciação e estigmatização dos estudantes que faziam parte da PUC, como se o fato de

\footnotetext{
${ }^{6} \mathrm{~A}$ pesquisa apontou algumas delas.

${ }^{7}$ Alguns autores fazem uma distinção entre as universidades privadas e a PUC-Rio quando analisam o processo de democratização do ensino superior no Brasil. Segundo alguns deles, as instituições católicas se aproximam das públicas com maioria de alunos de classe social mais privilegiado, devido à concorrência maior nos processos seletivos do vestibular. Deve ser feita, nesse sentido, uma discussão diferenciada acerca da experiência do PROUNI nestas instituições, - que sem duvida, apontaria para particularidades da experiência na PUC e para as demais instituições de ensino privado.
} 
estudar nesta Universidade significasse a traição de um ideal ou algo similar a um pacto com o 'sistema capitalista', considerado como o maior responsável pela opressão às camadas populares.

Vejamos como teriam acontecido algumas destas trajetórias, no início:

Ea/19 - mas eu queria UERJ, eu não queria PUC! Eu achava que a coisa só ia se realizar se fosse numa Federal, no Fundão! (...) Não sonhava muito com Fundão não, queria UERJ! (...) Pelo nome e aí já tinha alguém que falava alguma coisa... reivindicação, sempre muito ativa... tinha uma amiga minha que estudou no CAP da UERJ.. era cheio de benefícios, de agitação, de movimento em termos de direitos... então, eu queria UERJ. Aí eu fiz a PUC... tinha uma coisa que a gente já sofria antes. Dentro do pré-vestibular, a PUC não era tão difundida pros alunos. Era uma opção, que entrava pela parceria com o curso, mas aqui dentro, a gente tinha o preconceito de quem entra pra PUC....

Eo/19 - porque a visão negativa de que era fácil..

E0/28 - vestibular...

Ea/19 - ... tinha uma coisa do particular e aí... se era função do Estado ou não era... é benefício ou não é... é obrigação e não é... e aí era uma confusão! e pra quem não tava era uma oportunidade mas, ao mesmo, tempo, dizer que ia tentar a PUC(...) virou alvo pra algumas pessoas!

$\mathrm{Ea} / 11$ - no início eu fiquei meio apreensiva.. de pessoas.. sei lá.. discriminarem.. Porque, esse processo de cotas, de PROUNI, já foi em embate muito longo. Eu participei da votação da lei, fui na assembléia legislativa. Porque o movimento de que eu fiz parte lutou muito pra isso! Então... como é que eles vão recepcionar a gente? Porque eles já.. Ah! São pessoas incapazes! Se precisam disso é porque não estudam! Sempre viam a gente como inferiores! E..pensava: 'se eles chegarem na faculdade e não conseguirem acompanhar o ritmo de estudo?" (Barcellos, 2007, p.121)

O curso pré-vestibular comunitário é, sem sombra de dúvidas, peça fundamental, tanto no processo antecedente ao ingresso no espaço acadêmico, como durante o processo de formação dos jovens no curso superior. Ficou bastante nítido, através destes e de outros depoimentos, o quanto estes movimentos sociais - alguns deles - além de se preocuparem com a aprovação de estudantes de baixa renda nos vestibulares, possuem convicções políticas que superam este primeiro objetivo.

Os cursos pré-vestibulares comunitários, conforme Mariz, Fernandez e Batista (2003), tiveram seu início na Bahia, sob o viés político do movimento negro. "O pré-vestibular foi proposto como instrumento de conscientização, articulação e apoio à juventude negra da periferia de Salvador (p.333). No caso específico do Rio de Janeiro, a primeira experiência ocorreu em são João de Meriti, na Baixada Fluminense, em 1992/93, tendo por principal articulador o Frei Davi R.Santos, embasado por reflexões de grupos envolvidos com as questões de espaços populares e eclesiais, em especial tendo por base a Pastoral do Negro, sendo a proposta disseminada posteriormente para várias localidades do Estado do Rio de Janeiro. (Barcellos, 2007) 
Em consonância com as concepções de Mariz, Fernandez e Batista (2003), pode-se concluir que:

Esses grupos pretendem não só preparar o estudante para entrar na universidade, mas também formar uma 'consciência negra e de classe'. Colocar negros e outros de origem popular em universidades é uma proposta de luta que alia o progresso individual a uma luta social. Não vendo necessariamente uma tensão entre esses dois projetos, os que fazem esse cursinhos de pré-vestibular sabem também dos limites de sua ascensão econômica ao ingressar na universidade. (Mariz e Fernandez e Batista, 2003, p.334 in: Barcellos, 2007, p.49).

Estes autores destacam ainda que, além de preparar o estudante para aprovação no processo seletivo do vestibular, esses cursos tinham em sua grade curricular uma disciplina intitulada "cultura e cidadania", tendo por proposta a discussão de temas como democracia racial e outros atrelados à temática da 'cidadania para populações negras e carentes'. (Barcellos, 2007)

Dauster (2004), tendo coordenado uma pesquisa análoga, objetivando, a princípio, mapear as relações entre os estudantes universitários e a cultura letrada, debruçou-se na investigação destes alunos, nos seus modos de vida e em seu cotidiano. Dentre os vários aspectos abordados pela autora, cumpre destacar justamente a importância destes projetos sociais "no ingresso na universidade e no estabelecimento de uma rede de relações de intercâmbio de trocas imateriais e regras de reciprocidade como base da vida social" (Mauss, 1974:p.24, 25 In: Dauster, 2004). Sobre os estudantes provenientes destes cursos, a autora ressalta que

(...)eles tendem a atuar também como mediadores, ora exercendo o papel de estudantes, ora a função solidária de professores de vestibular (...) esses estudantes revelam alto grau de coesão interna, ancorados em uma visão política do seu significado social enquanto universitários. (Dauster, 2004)

A experiência do Programa de Ação Social na PUC-Rio, antecedente à implementação da política de reserva de vagas nas instituições publicas ${ }^{8}$, pôs á mostra, dentre várias outras problemáticas, três de grande pertinência:

(1) O processo de democratização das instituições de ensino superior, no Brasil, ocorreu num misto entre iniciativas no âmbito público e privado. Este fato gerou controvérsias e polêmicas que têm permeado o campo educacional, como as controvérsias entre educação como um bem público, direito de todos ou como um bem mercadológico, portanto acessível tendo por base a perspectiva da meritocracia. Na medida em que se fala em prover educação em condições de

\footnotetext{
${ }^{8}$ Esta última teve suas primeiras experiências em 2002 e 2003 na UERJ, UENF e UNEB E UNB.
} 
equidade para todos, fala-se também em todos os aspectos inerentes a estas condições.

(2) Os movimentos da sociedade civil organizada impulsionaram políticas públicas de Estado influenciando não somente a legitimação de ações jurídicas perspectiva macro -, como os modos de posicionarem-se dos sujeitos envolvidos - perspectiva micropolítica -, o que significa dizer que: compreender Políticas de Estado implica em entendê-las na interseção/tensão com as várias forças sóciopolíticas envolvidas.

(3) As ações dos movimentos sociais no campo educacional, no Brasil, conjugam interesses mais amplos do que propriamente o ingresso de estudantes menos favorecidos economicamente. Os movimentos vinculados aos prévestibulares comunitários, por exemplo, estão atrelados diretamente às temáticas de cunho racial e sobre processos identitários. Tais iniciativas fazem parte do rol de ações afirmativas e, por esse motivo, englobam um conjunto de propostas voltadas para grupos desfavorecidos, não somente do ponto de vista econômico, mas também social e cultural. Com a palavra: o movimento negro.

\title{
2.8. Movimento Negro Brasileiro e Educação: Aspectos Históricos e Ações Propositivas
}

\begin{abstract}
Nós, negros e negras, trabalhadores em Educação, por sentirmos a urgente necessidade de que o sindicato da Educação - Apeoesp e Afuse - assuma a nossa bandeira de luta para o resgate da cultura afro-brasileira, como princípio de emancipação do Negro-Cidadão, que sofre as conseqüências da Educação diferenciada, conclamamos a todos os trabalhadores negros, brancos e amarelos deste Congresso, do Estado de São Paulo do Brasil a: (1) Assumir conosco o compromisso histórico de erradicar o analfabetismo que assola este país, cuja maioria afetada é de negros e pobres; (2) Resgatar os valores históricos culturais e humanos dos negros, através da formulação da nossa prática educativa/pedagógica na sala de aula e na sociedade; (...) (6) Propor e organizar nas escolas, cidades e regiões; encontros, fóruns ou Semanas de discussões sobre a questão do negro e da cultura afro-brasileira, com o objetivo de despertar a consciência dos alunos, da população como um todo e da comunidade negra em geral, para o compromisso da luta contra o preconceito, a discriminação e o racismo, ideologizados subjacentemente na sociedade brasileira pela linguagem do poder branco e opressor." São Paulo - Anhembi - 5 de abril de 1991. Congresso Estadual de Educação - Comissão Manifestante. (Souza in: Pinsky, 2004, p.40)
\end{abstract}

O manifesto subscrito diz respeito a um documento elaborado por um coletivo composto por vários integrantes de diferentes instituições, com destaque para Apeoesp - Sigla do Sindicato dos Professores do Ensino Oficial do Estado de São Paulo -, a partir do qual se constituiu, na década de 1990, o Coletivo Estadual Anti-Racismo Milton Santos. (Souza, 2004) 
Duílio Duka de Souza, um dos autores do manifesto, relata uma série de eventos, entre seminários, congressos e reuniões, que resultaram na confecção deste documento, envolvendo trabalhadores da área de educação, integrantes do referido Sindicato - representados pela diretoria do Coletivo Estadual Antiracismo Milton Santos -, diretores de escolas, integrantes do Instituto Sindical Interamericano pela Igualdade Racial (INSPIR) e muitos outros. Souza (2004) inclui, ainda, no conjunto de eventos que influenciou na elaboração do manifesto, a Conferência de título: "Contra o Racismo, a Discriminação Racial, Xenofobia e formas Correlatas de Intolerância”, ocorrida em 2001, Durban, África do Sul.

O destaque aqui reservado ao manifesto aponta pistas sobre os rumos que têm tomado as lutas e reivindicações de militantes do movimento negro brasileiro, especialmente no período compreendido entre 1990 e o momento atual ${ }^{9}$.

É notório o número de ações e propostas envolvendo temáticas raciais na área da educação na cena contemporânea. Não é por acaso. A Conferência de Durban, um dos marcos indiscutíveis na luta do movimento negro em escala mundial e com importantes efeitos para o Brasil, previu, conforme Souza (2004, p.42), a implementação "de políticas públicas para eliminação das desigualdades raciais e sociais, por meio da elaboração de programas com recursos adicionais para educação, saúde, entre outros (...), destinados aos afrodescendentes." Contudo, este autor enfatiza a grande importância da educação neste contexto, estando neste campo as condições desiguais e excludentes a que vem sendo submetida a população afrodescendente com a conseqüente impossibilidade do exercício pleno da cidadania. É o que argumenta:

A discriminação racial praticada em nossa sociedade viola o direito à igualdade $\mathrm{e}$, conseqüentemente, à cidadania. Dados da Pesquisa Nacional por Amostra de Domicílio (PNAD) nos mostram que a educação tem sido responsável pela exclusão de grande parcela da população negra que não se percebe cidadã, já que a política pedagógica não favorece a diversidade pluriétnica nas escolas públicas e os livros didáticos não são adequados à pluralidade racial, perpetuando o preconceito por meio de seus conteúdos. (p.42).

\footnotetext{
9 Antes de tudo, cabe ressaltar que o "movimento negro" não é uma entidade homogênea. Longe de pretender abordar, do ponto de vista histórico-político, o percurso do movimento negro no Brasil - seria no mínimo leviano, dada a complexidade e as diversidades existentes nos vários coletivos de militantes, nas suas posições e ações - trata-se, sobretudo, de mostrar a participação fundamental deste movimento tanto na implementação de políticas publicas na área da educação voltadas para esse público quanto na mobilização de ações sociais e de transformações nos campos da cultura, social e ideológico. Permanece a perspectiva dialética como forma de tentar compreender o tema da política de reserva de vagas nas universidades públicas brasileiras e os embates suscitados no processo de sua consolidação.
} 
É Souza (2004) ainda quem denuncia as condições de trabalho dos profissionais da educação - já que delas compartilha -, como precarizadas e insuficientes, além das falhas na própria organização do sistema de ensino, de modo a inviabilizar a consolidação de um trabalho qualitativo. Acredita, contudo, que mudanças nestas estruturas e a conscientização política da "função social da escola" são saídas possíveis para garantir uma democracia tanto "econômica"(...) quanto "política, social e racial" (p.43)

As palavras contidas no manifesto aliadas às considerações de Souza $(2004)^{10}$, indicam que as reivindicações não encontram-se restritas à dimensão econômica, mas sobretudo no plano ideológico. Alguns termos como Linguagem, cultura, história, consciência associadas à preconceito e discriminação marcam um momento histórico do movimento em que as lutas caminham no sentido de reivindicação de direitos, dentre os quais incluem-se os de reconhecimento, visibilidade, respeito às origens, cultura, de serem autores da própria história.

No percurso histórico do movimento no Brasil, verifica-se, de acordo com Gonçalves \& Gonçalves e Silva (2004) e outros teóricos, que o campo de ação do movimento negro foi se amplificando e diversificando, intervindo tanto nas políticas governamentais quanto através dos movimentos sociais organizados.

A necessidade de propostas de ação nas várias esferas políticas ressoa nas afirmações de Souza (2004), quando atribui a origem das desigualdades raciais às duas instâncias: governo e sociedade civil, alegando que: “(...) quem cria as desigualdades raciais são de um lado: a passividade, a permissividade e o naturalismo na esfera da sociedade e de outro lado: a demagogia, a burocracia e o racismo, na esfera de governos". (p.44)

Os aspectos usados no manifesto e postos em relevo - cultura, linguagem, história usados como ferramentas de discriminação e preconceito racial encaminham discussões que encontram reforço nas tendências multiculturalistas, já antes postas em análise no texto.

A aproximação do movimento negro a perspectivas multiculturais, como explica Gonçalves \& Gonçalves e Silva (2004), no Brasil ocorreu numa época em que o "paraíso racial" sequer pensava em ser questionado no país, momento este em que o próprio movimento negro, ainda pouco articulado deste ponto de vista, compreendia um pequeno grupo de uma população negra de maior escolaridade que a maioria, que focava suas reivindicações na inserção no

\footnotetext{
${ }^{10}$ Militante, educador, um dos autores do artigo e do próprio manifesto.
} 
mercado de trabalho nas mesmas condições e oportunidades que os brancos e na construção de uma imagem menos negativa na sociedade.

Este autor remete-nos à cidade de São Paulo, nos primórdios do século $X X$, quando as primeiras denúncias de que o Brasil se tratava de um país racista, ainda que não se considerasse como tal, começam a vir à tona por intermédio de negros e mestiços que, ingressantes no "jogo competitivo da sociedade urbana e moderna" reivindicam posições e iguais oportunidades. (Gonçalves \& Gonçalves e Silva, 2004). Já na primeira metade de nosso século, segundo relata, entidades em defesa dos direitos dos negros, nas cidades de São Paulo, Porto Alegre, Santos, entre outras, organizavam em função da inserção desta população "no mundo secularizado" (p.68) É neste sentido que o autor considera que as primeiras aproximações do movimento negro ao multiculturalismo são de perspectiva integracionista.

Especificamente sobre o movimento na cidade de São Paulo, o autor resgata a memória de Correia Leite, um dos militantes, publicada em 1992, quando em um de seus relatos afirmava aos militantes dos anos 80 que estes não poderiam compreender o sentido de remeterem-se às suas tradições e origens passadas como forma de afirmação étnica, ao contrário dos militantes negros dos anos 20 , época mais próxima da escravidão, tendo gerações mais próximas da vivencia da escravidão, cujas recordações e lembranças mais imediatas - a senzala e seu entorno - jamais gostariam de recordar.

Nos anos 40, então, insurgem iniciativas mais aproximadas com reivindicações de cunho ideológico e cultural no Brasil, intervindo no que os autores intitulam de "política de significados", fazendo menção ao modo como chamavam os pesquisadores norte-americanos. Assim sendo, "as organizações negras passam a contar com algumas condições culturais que lhes permitem colocar em cheque 'os modos de inteligibilidade e as estruturas ideológicas de construção de sentido." (Ebert, 1991 in: Gonçalves \& Gonçalves e Silva, 2004, p.70)

Estes autores concluem, sobre o movimento multicultural no Brasil, na perspectiva étnica - passando ao longo do tempo a abarcar várias frentes, no campo das artes, da cultura e da própria academia -, que este foi, "ao mesmo tempo um trabalho de conservação, de inovação e de valorização do patrimônio cultural afro-brasileiro." (p. 79) Segundo eles,

As transformações culturais pretendidas pelos afro-brasileiros tinham objetivos bem definidos e fins educativos: educar o branco. Essa educação deveria subverter o quadro cultural do país, pois os militantes estavam convencidos de 
que o sentimento de inferioridade vivido pelos negros estava enraizado na cultura brasileira. (p.78)

De volta à cena contemporânea, década de 90, mais especificamente, ganha visibilidade um conjunto de ações propositivas impulsionado pela luta do movimento negro brasileiro. Pautas reivindicatórias ganham espaço na agenda política governamental, aliadas às ações de movimentos sociais ${ }^{11}$. Neste contexto, Paiva (2010) elenca três aspectos centrais que impulsionam as políticas públicas vigentes, são eles: o reconhecimento, por parte do Estado de que havia racismo no Brasil; as ações dos movimentos sociais, com destaque os movimentos pré-vestibulares comunitários e o próprio movimento negro e, por fim, a Conferência realizada em Durban, em 2001 e suas ações e proposições.

Dentre os aspectos destacados, foquemos no que se refere à atuação dos movimentos sociais. De acordo com estas autoras, na década de 80, uma primeira ação política ganha relevo: as estratégias usadas pelo "movimento negro unificado" - segundo Paiva (2010) reestruturado na década de 80 - em função, principalmente de reivindicar o acesso à educação e denunciar o racismo.

Esta autora comenta que, a despeito das diferenças existentes entre os vários grupos de militantes do movimento negro, duas temáticas têm feito parte da maioria deles: "1. A denúncia de racismo que permeou as relações na sociedade brasileira e que contribuiu para resultados assimétricos de status social; e 2. A recusa em se submeter a esses padrões assimétricos e aos lugares tradicionalmente designados a eles." (p.15) É em razão destes dois aspectos que a educação entra em cena. Explica a autora que:

A educação foi compreendida como o grande direito a ser conquistado para que esses padrões começassem a ser modificados: se hoje há políticas de ação afirmativa para os "negros" ou "afrodescendentes", traduzindo a constituição de uma identidade negra difícil de ser conquistada em um país onde se reforça a idéia de mestiçagem nas relações sociais, elas traduzem reivindicações baseadas nesse processo de afirmação de nova identidade. (p.15)

A política de reserva de vagas, com maior visibilidade a partir da instituição do recorte racial como critério, tornou-se viável, sobretudo, por mudanças nas

\footnotetext{
${ }^{11}$ Não se pode perder de vista que essa corrente faz parte de um momento em que a sociedade civil organizada, em várias frentes representativas, assume intensa participação na cena política. Paiva (2010) atribui à carta magna de 1988 e aponta certa tendência de "forte associativismo" na década de 80 , englobando desde associações de bairros até movimento sociais, propriamente ditos, intervindo na reivindicação " de antigas e novas demandas" com características de "um protagonismo da sociedade civil" até então inovador na pública do país. (p.12)
} 
posições do Estado no que tange ao tema do racismo no Brasil. Maio e Santos (2005) trazem uma sequência de acontecimentos representativos do percurso de Estado antes indiferente quanto ao tema e, posteriormente, atento e atuante assumindo para si propostas de enfrentamento da discriminação e das desigualdades raciais no país. "De um estado 'neutro' em matéria racial até meados dos anos 1990, observa-se a formulação de propostas de políticas públicas racializadas".

Brandão (2005) concorda com as considerações anteriores, como afirma a seguir:

\begin{abstract}
Para o ministro, a introdução das políticas de ação afirmativa representou, em essência, uma mudança da postura do Estado, que, em nome de uma suposta neutralidade, aplicava suas políticas governamentais indistintamente, ignorando a importância de fatores como sexo, raça, cor origem nacional" Ao adotar políticas de ação afirmativa, o estado passa a levar em conta esses fatores, ou seja, ao invés de conceber políticas públicas das quais todos seriam beneficiários, independentemente de sua raça, cor ou sexo, o Estado passa a levar em conta esses fatores na implementação das suas decisões, não para prejudicar quem quer que seja, mas para evitar que a discriminação, de inegável fruto histórico e cultural, finde por perpetuar as iniqüidades sociais. (Gomes, 2002, p.132 in: Brandão, 2005,p.37)
\end{abstract}

Dentre as maiores controvérsias geradas neste processo, desde 1970, a maior parte delas situava-se em torno do debate sobre "o mito da democracia racial e o racismo à brasileira" (2005, p.185). Estas discussões ganham repercussão nos textos acadêmicos, na área de ciências sociais, em que novas interpretações sobre as relações raciais no Brasil ganham expressão.

Dissonâncias no interior do movimento negro entremeavam as posições assumidas pelo movimento contemporâneo, que, segundo Maio e Santos (2005), teve sua "virada político-ideológica" marcada pela criação do "movimento negro unificado contra a discriminação racial", em 1978. (p.186)

Até a chegada dos anos 90 - atravessando os anos 80 - esforços foram feitos, especialmente envolvendo alianças entre sociólogos das relações raciais e movimentos sociais, em fóruns e pesquisas.

Entremeados de controvérsias e debates, segundo os autores, dentro do próprio movimento negro, o tema ganha espaço na pauta do governo. Alguns acontecimentos foram destacados por Maio e Santos (2005), como a constituição por parte do presidente Fernando Henrique Cardoso, na data de 20 de novembro de 1995, do Grupo Interministerial para a Valorização da População Negra e a Conferência de Durban, já mencionada. Seus efeitos, no 
âmago das questões dos direitos humanos, foram notados pela consolidação de ações propositivas em esfera governamental, como relata os autores:

Logo após a Conferência, o governo brasileiro definiu um programa de política de cotas no âmbito de alguns ministérios (...). No plano estadual e municipal, diversas iniciativas foram realizadas para a implementação do sistema de cotas. Aquela que obteve maior destaque no final do ano de 2001 foi a da assembléia legislativa do estado do Rio de Janeiro que estabeleceu uma porcentagem das vagas nas universidades estaduais para pretos e pardos. A partir de 2002, o debate e a implementação de políticas de ação afirmativa com viés racial, com foco no sistema de cotas, estenderam-se por diversas universidades publicas e privadas, tanto estaduais como federais. (2005, p.189)

Com a palavra, as experiências da política de reserva de vagas nas universidades públicas brasileiras.

\section{A política de reserva de vagas nas universidades públicas brasileiras}

\subsection{As Primeiras Experiências}

A ação de maior repercussão na sociedade brasileira foi - e tem sido - de fato a aprovação da política de reserva de vagas para alunos negros em escolas estaduais, em 2002, tendo como pioneiras a Universidade do Estado do Rio de Janeiro - UERJ e a Universidade Estadual do Norte Fluminense - UENF, acompanhadas por outras universidades em períodos posteriores. Destaca-se ainda o caso da UNB - Universidade de Brasília - como a primeira Universidade Federal do país a adotar a política.

A Universidade Estadual da Bahia (UNEB), através do seu Conselho Universitário, mediante a resolução oำ196/2002, aprova um plano de ações afirmativas para afrodescendentes advindos de escolas públicas, além de outras muitas instituições que passam a adotar políticas de ações afirmativas de modos variados, cada qual com suas particularidades.

As experiências em cada instituição apresentam aproximações e distanciamentos. Suas análises devem considerar os dois aspectos entrecruzados: o que há de comum e as particularidades. Não há como tomar cada uma destas instituições isoladamente, visto que as temáticas e repercussões deflagradas dialogam e se misturam. As distinções entre elas decorrem, dentre outras razões, das características de cada região na qual se 
localiza a instituição, das posições e da lógica sócio-política interna a cada uma delas e das vivências no cotidiano acadêmico.

Várias experiências se iniciaram de modos os mais plurais, sendo, entretanto, efetivamente construídas no cotidiano das universidades. Uma vez implementadas, impasses e demandas surgem a todo o momento, mobilizando cada uma delas a debater e tentar sanar as lacunas ${ }^{12}$.

Tendo seu início no processo seletivo do vestibular de $2003^{13}$, a experiência da Universidade Estadual da Bahia (UNEB) teve um percurso distinto da Universidade do Estado do Rio de Janeiro (UERJ) uma vez que, conforme analisa César (2004), a implementação da proposta na primeira não desencadeou maiores contrariedades e tensões do ponto de vista jurídico quanto no caso da segunda instituição.

Dentre as razões, César (2004) menciona a lei n 9394/96, cuja interpretação "atribui às universidades um âmbito deliberativo sobre seus critérios de seleção para o vestibular", além do fato da participação da própria universidade no projeto, o que significou a realização de medidas e de uma política educacional eficaz, com positivas repercussões dentro e fora do contexto universitário.

Mattos (2004) salienta o caráter pioneiro da UNEB e as peculiaridades da experiência nesta instituição, comparativamente às demais universidades estaduais, quando afirma que:

$\mathrm{Na}$ Uneb, o sistema de cotas, embora tenha sido provocado por uma iniciativa externa, organizou-se como uma proposição da própria comunidade acadêmica que, através da Reitoria, da Comissão referida e do órgão deliberativo máximo da instituição, valeu-se do princípio da autonomia universitária e independência dos seus fóruns decisórios internos para deliberar sobre a matéria. (p. 201)

Outro dado que justifica o fato da experiência na UNEB ter ocorrido de modo menos penoso do que no caso da UERJ é a própria "conjuntura social, política e institucional local" (p.62). As características sócio-econômicas e culturais da população bahiana, composta em termos majoritários por afrodescendentes (p.62), muito contribuíram para garantir a legitimidade da resolução n196/2002 na Universidade e perante a sociedade mais ampla.

\footnotetext{
12 "Hoje, mais de vinte Universidades Brasileiras implementam estratégias diferenciadas de acesso baseadas em critérios raciais, sociais ou étnicos. Ao mesmo tempo, tramita no Congresso Nacional um projeto de lei (PL 73/99), que pode tornar as cotas obrigatórias para todas as instituições de ensino superior nos próximos anos" (Ferreira e Andrade, 2006).

${ }_{13}$ "Embora a primeira experiência seletiva a partir da edição da Resolução tenha se dado na seleção de alunos especiais para o Mestrado em Educação e contemporaneidade, o concurso vestibular 2003 foi o momento inaugural de experimentação da medida na exata dimensão da sua importância." (Mattos,2004, p.202)
} 
O caso da Universidade de Brasília, por sua vez, traz algumas peculiaridades em relação às demais instituições (UERJ e UNEB). Além de ser a primeira experiência de reserva de vagas em instituições Federais do país, conforme César (2004), o caso da UnB traz, de imediato, a proposta de uma política de permanência que a complementa incluindo, dentre as diretrizes: a) um programa de estímulo aos alunos "negros" do segundo grau de educação pública, com o objetivo de melhorar a qualificação dos alunos nesse nível de ensino; b) suporte financeiro para os alunos através de bolsas de manutenção para os estudantes que necessitarem; c) apoio acadêmico pedagógico para os que dele necessitarem, entre outras medidas.

Além disso, diferentemente dos casos da UERJ e UNEB que optaram pelo critério de auto-declaração para identificação racial, a UnB exige, ainda, uma comprovação externa e mais objetiva da percepção da cor do candidato, mediante a apresentação de fotografia e avaliação de um comitê como forma de evitar possíveis fraudes. Neste sentido, outras discussões e polêmicas surgem por conta destas medidas, uma vez que se adota a aparência dos candidatos como forma de seleção, dividindo opiniões e aumentando as tensões do debate sobre o tema ${ }^{14}$.

\subsection{A UERJ e a Política de Reserva de Vagas: Histórico e Principais Aspectos}

A UERJ foi uma das primeiras a aderir ao sistema de reserva de vagas para estudantes. A experiência tem gerado controvérsias e polêmicas. Há que se ter claro que a experiência - como todas - vem se construindo no cotidiano. Para compreender melhor a experiência na UERJ e seus efeitos é preciso, antes, conhecer o histórico e origem desta instituição.

Villardi(2007) comenta que a UERJ surge a partir da junção de faculdades - que até então funcionavam isoladamente - formando a Universidade do Estado.

Batista (2007), em pesquisa sobre o surgimento e funcionamento do Programa Políticas da Cor - PPCOR, situado no laboratório de políticas públicas

\footnotetext{
${ }^{14} \mathrm{Em}$ anexo encontra-se um quadro comparativo trazendo alguns dos principais aspectos das experiências de reserva de vagas nas três universidades citadas. As informações do quadro foram extraídas de: César, R.C.L. Questões jurídicas do sistema de reserva de vagas na universidade brasileira: um estudo comparado entre UERJ, UNB e UNEB. Programa políticas da cor na educação brasileira. Série ensaios \& Pesquisas 2 - universidade do estado do rio de janeiro. Laboratório de Políticas Públicas. Governo Federal. Secretaria Especial de Promoção de políticas de Igualdade Racial. Rio de Janeiro, setembro de 2004.
} 
da UERJ, comenta que a fundação desta universidade se dá em 1950, ainda denominada Universidade do Distrito Federal. Em 1960, em razão da mudança da capital federal para Brasília, passa a ser Universidade do Estado do Rio de Janeiro. (p.49)

Embora nos anos mais recentes apresente um quadro de alunos majoritariamente provenientes de uma elite econômica - especialmente no que se refere aos cursos de maior prestigio e status social -, a UERJ teve sua origem marcada pela preocupação com a formação do "estudante/trabalhador". Comenta Villardi (2007):

A UERJ sempre teve o compromisso de atender uma parcela da população que não era atendida pelas universidades federais. Há exatos 30 anos, quando se inaugurou o campus Maracanã, todos os cursos eram noturnos. O perfil da Universidade sempre foi de um aluno trabalhador. (Villardi, 2007, p.37)

Segundo ainda a sub-reitoria de graduação da UERJ, em função do fato da instituição ter sido estruturada em função de um perfil de estudantes específico o estudante/trabalhador - atrelado a outros aspectos, como "não possuir tradição de pesquisa, não possuir professores com dedicação exclusiva e não possuir um parque de pós-graduação" (2007, p.36), a instituição, por um longo tempo, vivenciou certo prestígio no cenário acadêmico. A esse respeito comenta também Valentim que "até a realização em 1985, do I Congresso Interno da UERJ, [A UERJ] não contava com programas de pós-graduação, o que não the conferia o prestígio social e acadêmico (...)". (2005, p.41)

Villardi (2007) recorda que a Universidade do Estado, nos anos preliminares, cobrava o pagamento de semestralidades dos graduandos. As mudanças para gratuidade aconteceu como resultado de lutas políticas dos próprios alunos. A autora relata o acontecido trazendo sua própria experiência na qualidade de aluna e militante à época:

Eu era estudante quando nós fizemos um movimento - em plena ditadura militar para derrubar o pagamento da semestralidade. Quando conquistamos essa vitória e nos equiparamos Às demais universidades federais, nossa organização demonstrou que os universitários da noite também tinham valor. (p.36)

Valentim (2005) cita Freire (2003) quanto à sua estrutura e lógica de funcionamento:

Essa universidade, pela sua própria estrutura física e localização, foi concebida como microuniversidade urbana, para atender jovens do município do Rio de Janeiro, voltada essencialmente para a formação de profissionais para o mercado de trabalho, diferente das outras universidades públicas, tendo também a característica de ter muitos cursos noturnos; concebida, portanto, para ser uma 
universidade de formação profissional com pouca inserção na pesquisa, por exemplo. A UERJ mudou completamente, de uns quinze anos prá cá, o seu perfil, passando a atender o Estado do Rio de Janeiro, ampliando sua pós-graduação, sua inserção na pesquisa, etc. (p.11)

A UERJ traz ainda como marco de sua criação a realização de atividades voltadas para a extensão e a "interiorização de seus cursos a partir dos anos 80 do século passado, com a criação da Faculdade de formação de professores, em Duque de Caxias" (p.42)

A autora comenta que, através da aplicação de questionários anuais, obteve-se a informação de que a universidade já contava, em seu corpo discente, com uma quantidade expressiva de estudantes provenientes dos segmentos menos favorecidos economicamente. Entretanto, ainda assim, fica nítida a prevalência de estudantes afrodescendentes e de baixa renda nos cursos menos elitizados, em função da maior concorrência e relação candidato/vaga, quadro este que começa a apresentar mudanças a partir de 2003.

Batista (2007) através de dados extraídos do folheto do DataUERJ, explica que esta universidade, hoje, se estrutura através de "31 cursos de graduação e 29 unidades acadêmicas, vinculadas a quatro centros setoriais, responsáveis pela articulação de diversos institutos e faculdades". (p.49) Seguem, segundo a pesquisadora, a distribuição dos cursos e os campi pertencentes às universidades que agregam hoje aproximadamente 22.829 estudantes ${ }^{15}$ :

\begin{abstract}
Através da lei n3524/2000, de 28 de dezembro de 2000, que estabeleceu a cota de $50 \%$ das vagas em cada uma das universidades estaduais públicas do Rio de Janeiro - UERJ e UENF (Universidade Estadual do Norte Fluminense, em Campos) para estudantes que tivessem cursado integralmente os ensinos fundamental e médio em escolas públicas, mantidas pelo poder público do Estado do Rio de Janeiro, e em seguida pela Lei n3708/2001, de 9 de dezembro de 2001, que determinou também para as duas universidades estaduais públicas citadas, a reserva de $40 \%$ das vagas de cada um de seus cursos de graduação para estudantes negros e pardos. (...) No ano seguinte, tendo em vista as incrongruências que se apresentaram na aplicação das duas leis, a UERJ propôs mudanças no projeto, como, a unificação das duas modalidades de cotas. O Vestibular Estadual 2004, então, reservou 20\% das vagas para estudantes de escolas públicas; $20 \%$ para negros e $5 \%$ para deficientes físicos e minorias étnicas. (Almeida, 2007, p.10)
\end{abstract}

Segundo explica ainda Almeida (2007), "os candidatos às cotas só concorriam por uma das modalidades e tinham que comprovar carência

\footnotetext{
${ }^{15}$ Este quantitativo de estudantes matriculados no momento da pesquisa de referência (2007) teve por fonte de investigação a divisão de informática e o sistema acadêmico da graduação, no segundo semestre de 2006.
} 
financeira, ou seja, renda máxima de $\mathrm{R} \$ 300,00$ líquidos por pessoa da família". (p.10)

$\mathrm{Na}$ medida da implementação da política na universidade, modificações ocorreram tanto no que se refere ao perfil sócio-econômico exigido para que o candidato pudesse concorrer à reserva de vagas, quanto aos próprios critérios de pontuação no processo seletivo do vestibular. A renda familiar exigida hoje para que o candidato ingresse via sistema de cotas é de $R \$ 630,00$ brutos por pessoa da família, além de terem sido estabelecidas modificações na pontuação mínima necessária para aprovação na primeira fase do concurso - 20 pontos em 100 possíveis - e a supressão de uma das três provas discursivas sobre matérias específicas para cada carreira, sendo a língua portuguesa obrigatória para todas as áreas" (p.10); critérios estes válidos para todos os estudantes participantes do processo seletivo, independente de concorrerem ou não às vagas reservadas.

Após o período compreendido entre 2004 e 2007, ou seja, quatro anos de vivência da política na UERJ, iniciaram-se várias análises focalizando os avanços e os impasses, bem como discussões sobre possíveis estratégias de enfrentamento.

Através do levantamento bibliográfico acerca do tema, já é possível encontrar algumas obras e publicações que se propõe a realizar um balanço dos efeitos da política nas universidades.

No que se refere ao caso da UERJ, a obra "as políticas de ações afirmativas na Universidade do Estado do Rio de Janeiro" reúne alguns atores institucionais propondo-se a analisar a experiência, sob a perspectiva de setores administrativos da instituição.

Amadei (2007) apresenta informações concernentes à concretização da política de cotas na UERJ, entre 2004 e 2007, compreendendo os últimos períodos do processo seletivo do vestibular sob vigência da lei 5151/2003. A autora aborda aspectos variados acerca da experiência na UERJ, incluindo desde os critérios de seleção do vestibular ${ }^{16}$ com o advento do sistema, dados

\footnotetext{
${ }^{16}$ Segundo Amadei (2007), "a seleção de candidatos para ingresso nos cursos de graduação da UERJ compõem-se de duas fases”, quais sejam: o exame de qualificação, cujo '(...)objetivo é avaliar as competências e habilidades consideradas necessárias ao exercício pleno da cidadania, articuladas ao conteúdo formal adquirido ao longo do processo de escolarização' e o exame discursivo, em que são aplicadas três provas discursivas: língua portuguesa instrumental com redação, realizada por todos os candidatos, além de duas provas específica, de acordo com o curso escolhido, definidas a priori pelas respectivas unidades acadêmicas. $O$ resultado final do vestibular é composto pela nota no exame discursivo, acrescida de um bônus, em pontos, relativo ao conceito obtido no exame de qualificação." (p.15) Vale salientar que o órgão responsável pela execução da política de acesso aos cotistas e não-cotistas é o departamento de seleção acadêmica - DSEA.
} 
estatísticos abrangendo o número de inscritos para concorrer às vagas de cotistas e não-cotistas, percentuais acerca das relações candidato-vaga nos cursos e áreas variadas, relacionando a procura de candidatos às vagas não reservadas até perfis dos candidatos cotistas no que diz respeito aos aspectos socioculturais e econômicos. Dentre esses aspectos, destacam-se alguns de importância significativa para entender a experiência das ações afirmativas na UERJ.

A maior e menor procura pelos cursos por parte dos alunos cotistas e nãocotistas foram importantes fatores analisados no artigo. A autora apresenta tabelas com um demonstrativo dos 5 cursos de maior e menor procura pelos estudantes, discriminados entre os candidatos às cotas e os candidatos às vagas comuns, nos anos 2004, 2005, 2006 e 2007, respectivamente ${ }^{17}$.

Um último aspecto que merece ser destacado refere-se ao perfil sociocultural e econômico dos candidatos às cotas. De acordo com a autora, os candidatos são submetidos a um questionário composto por 40 perguntas com o objetivo de mapear o perfil destes estudantes quanto aos quesitos renda familiar, perfil pessoal, socioeconômico e cultural, dentre outros.

A pesquisa aponta questões importantes, como a diferença da importância do trabalho na vida dos estudantes cotistas e não-cotistas, por exemplo. Explica a autora que:

\begin{abstract}
Pelo menos $50 \%$ dos cotistas e dos não-cotistas informaram nunca ter trabalhado e cerca de $20 \%$ dos não-cotistas e $30 \%$ dos cotistas começaram a trabalhar com menos de 18 anos. Em relação à fonte de renda, cerca de $50 \%$ de ambos os grupos, informam não possuí-la. A mesada é a fonte de renda mais frequentemente apontada entre os não-cotistas, enquanto 0 trabalho é ligeiramente mais freqüente entre os cotistas. (p.24)
\end{abstract}

Dados como a renda familiar mensal e o acesso à internet foram também parte das questões e apresentaram diferença significativa em relação aos cotistas, que apresentaram evolução nos números relativos à posse de computador com o decorrer dos anos, e os não cotistas que demonstraram obter maior renda mensal e maior facilidade de acesso à internet do que os primeiros.

\footnotetext{
${ }^{17}$ Analisando de modo mai abrangente, pode-se constatar, segundo os dados apresentados, que dentre os cursos mais procurados pelos candidatos não-cotistas pelos quatro anos mencionados, se encontram o de medicina, jornalismo e desenho industrial. Em se tratando dos candidatos Às cotas, os cursos mencionados de maior procura seriam os de jornalismo, história e serviço social. No que se refere aos cursos menos procurados, destacam-se entre os candidatos às cotas os de estatística do Instituto de matemática e estatística e o curso de engenharia cartográfica, da faculdade de engenharia (ambos em 2007), cursos de matemática da faculdade de educação da baixada fluminense (2005) e de português/alemão, do curso de letras (2006). Quanto aos menos procurados pelos alunos não-cotistas, a autora destacou o curso de pedagogia II, da faculdade de educação da baixada fluminense no ano de 2005. (Amadei, 2007, 19/20)
} 
O artigo de título "Políticas de Ação Afirmativa: Uma Estratégia de Sobrevivência dentro da Universidade Pública", escrito por Márcia Souto Maior Mourão $S^{18}{ }^{18}$, aborda uma temática fundamental sobre a experiência das cotas na UERJ: as chamadas políticas de permanência. A autora define como: "estratégias político-acadêmicas (...) construídas no interior desta universidade, para combater a evasão e garantir a sobrevivência dos estudantes cotistas até a conclusão de seu curso universitário". (p.42)

Sá (2007) explica que, desde 2004, tem-se trabalhado em função de um projeto voltado prioritariamente aos estudantes ingressos pelo sistema de cotas na UERJ. Da responsabilidade do DEPEI - Departamento de projetos especiais e inovações, parte da sub-reitoria de graduação (SR/1), o PROINICIAR Programa de Iniciação Acadêmica - teve seu surgimento atrelado ao atendimento dos estudantes de graduação da UERJ, "preferencialmente aqueles que ingressarem por meio da lei que regulamenta o sistema de cotas" ( $p .43)$ Explica a autora:

\begin{abstract}
O principal objetivo desse programa, conforme deliberação 043/2004, é apoiar o estudante nos dois primeiros períodos, de modo a garantir-lhe a permanência na universidade, com aproveitamento, até a conclusão do curso, viabilizando a transformação da lei num efetivo mecanismo de redução das desigualdades sociais. O programa prevê a distribuição de bolsas de iniciação científica acadêmica, bem como um oferecimento de atividades para todos os estudantes envolvidos, além de um sistema de acompanhamento e avaliação permanente, sob a responsabilidade do DPEI. (Sá, 2007, p.43).
\end{abstract}

O projeto se estrutura em três eixos principais, quais sejam: oficinas, disciplinas instrumentais e cultural. O primeiro e o segundo eixos ficam a cargo da DEPEI/SR1, inclusive no que se refere aos critérios de escolha e seleção das oficinas. Os módulos são oferecidos pelas unidades acadêmicas, ficando a responsabilidade pelo acompanhamento técnico-pedagógico a cargo dos coordenadores de cada área. O terceiro eixo - o das atividades culturais compõem-se por "sessões comentadas de filmes, idas ao teatro, salas e concertos e espetáculos variados, visitas a museus e participação em grupos de arte popular" (p.44)

Sá (2007) comenta ainda que, uma vez instituída a política na UERJ, coube a esta instituição, e não somente aos órgãos governamentais, a criação de estratégias e ações internas no sentido de solucionar possíveis entraves,

\footnotetext{
18 Professora Adjunta da Faculdade de Educação da UERJ e diretora do Departamento de Projetos Especiais e Inovação da Sub-Reitoria de Graduação.
} 
sejam de ordem financeira sejam de natureza pedagógico-cultural. É como relata:

Se antes dessa data nosso censo universitário constatava a forte presença (cerca de $30 \%$ ) de estudantes sócio e economicamente carentes em nossos cursos de licenciatura, que, por sua vez, já haviam desenvolvido estratégias pedagógicas e financeiras para atendimento com qualidade de seu corpo discente, o mesmo não acontecia nos demais cursos de graduação e, em especial, nos considerados "nobres", como medicina, odontologia, direito e desenho industrial. Esses cursos desconheciam estudantes pobres em suas salas de aula, pelo simples fato de não fazerem parte de suas turmas.(ver referência)

Sá (2007) traz dados objetivos sobre a política de permanência que vem subsidiando o trajeto de estudantes cotistas durante a formação universitária. Entretanto, há que se por à mostra dois aspectos por ela mencionados que trazem em seu bojo componentes importantes acerca da experiência de jovens cotistas na UERJ. O primeiro foi o que a própria autora denomina de "rede de solidariedade" e o segundo poderia se definir como "uma mudança na autoimagem", que segundo acredita a autora, teria relação com a entrada no programa PROINICIAR.

A rede de solidariedade, posta em destaque no artigo, refere-se a um momento em que a coordenação do projeto de permanência, programa este ainda incipiente à época, consegue "junto ao Governo do Estado a liberação de recursos para pagamento de bolsas destinadas a todos os estudantes cotistas". Contudo, os pagamentos das bolsas sofreram um adiamento e foram pagos aos estudantes com o valor acumulado e retroativo e de uma única vez. Sá (2007) enfatiza a "rede de solidariedade" que se formou entre os estudantes, espontaneamente, durante o período em que os jovens ficaram desamparados financeiramente. Comenta a autora:

\begin{abstract}
A conseqüência mais fantástica desse atraso, no entanto, foi a rede de solidariedade que se formou entre os estudantes cotistas: nessa ocasião, os mais prósperos desse grupo adquiriram o material individualmente. A rede de solidariedade estendeu-se às demais instâncias do cotidiano universitário, abrangendo empréstimos de livros, textos, dinheiro para passagem e alimentação (...). Antes da entrada maciça de estudantes carentes, foi possível assistir, de forma isolada e pontual, a atos de comunhão fraterna de material individual, mas agora, como conseqüência, da convivência com a diversidade étnico-racial, o cotidiano acadêmico foi enriquecido pela prática da pluralidade e da tolerância. (p.45)
\end{abstract}

Sá (2007) destaca ainda outro aspecto presente na experiência dos jovens cotistas após o ingresso na universidade. A autora acredita que a possível depreciação da imagem dos cotistas anterior ao ingresso dos mesmos na universidade se modifica na medida em que passam a fazer parte do cotidiano universitário. Tal fato deve-se, de acordo com Sá (2007), às identificações dos 
estudantes cotistas entre si por semelhanças nas realidades sócio-econômicas, etnias e por terem sido submetidos aos mesmos critérios e processo seletivo de ingresso na Universidade ${ }^{19}$.

Os estudantes que ingressam na UERJ pelo sistema de reserva de vagas - os chamados cotistas - percebem-se iguais entre si, além pertencerem à mesma camada social e/ou mesma etnia, concorreram em igualdade de condições na seleção acadêmica para UERJ. Assim, a imagem socialmente depreciada e agregada ao grupo étnico de cotistas (negros, índios e deficientes físicos, ou mesmo o estudante pobre proveniente de escola pública) que antes do ingresso na universidade gerava uma desvantagem, é revertido positivamente no cotidiano universitário. Um dos fatores geradores de mudança de imagem é a entrada no Proiniciar - tratamento acadêmico preferencial - isso porque os estudantes cotistas buscam atingir através do mérito acadêmico o igualitarismo real e efetivo que antes os diferencia negativamente do grupo de não-cotistas. (p.45)

As experiências do sistema de reserva de vagas na UERJ têm sido, então, construídas ao longo de um processo ainda hoje em andamento. Ao mesmo tempo em que a instituição se deparava com problemáticas a serem enfrentadas, controvérsias e embates ocorriam, interna e externamente, ao campus universitário. Sendo assim, é no atravessar dos acontecimentos e das tensões por eles geradas que o tema precisa ser analisado. É importante tomar contato das maiores polêmicas e os diferentes posicionamentos.

\title{
3.3. A Política de "cotas": Você é a favor ou contra?
}

\begin{abstract}
Se por um lado o sistema de cotas pode promover a diversidade étnica e cultural no ambiente universitário, por outro ele se constitui num sistema de reserva de vagas para determinados grupos. Se, por um lado, quando se trata de cotas raciais, ele permite que grupos étnicos historicamente prejudicados tenham acesso ao ensino superior público, por outro lado, ele não resolve totalmente a questão dos excluídos das Universidades públicas por razões econômicas. Se, por um lado, esse sistema tem o objetivo de reparar injustiças históricas, por outro, ele promove novas injustiças. Se, por um lado, as cotas podem se constituir em meios acadêmicos capazes de propiciar mobilidade social aos afrodescendentes, por outro, essa mobilidade atinge, majoritariamente, os afrodescendentes de classe média e não os pobres, sejam eles negros, pardos ou brancos. Se por um lado, ele pode ser considerado como um instrumento de combate à discriminação, por outro lado, promove uma discriminação contra os grupos não beneficiados. Se por um lado, ele facilita o acesso ao ensino superior para indivíduos beneficiados, na maior parte das vezes, ingressam no ensino superior com um nível de escolaridade consideravelmente menor do que os alunos que ingressam pelo sistema de reserva de vagas. (Brandão, 2005, p.95/96)
\end{abstract}

\footnotetext{
${ }^{19}$ Cabe salientar que esta é uma das possíveis explicações, dentre uma pluralidade de outras existentes. Este capítulo tende explicitar as posições institucionais sobre o balanço da política na UERJ. No decorrer do trabalho, as outras vozes apresentarão as várias perspectivas de diferentes atores sociais sobre a experiência.
} 
A questão-título deste tópico foi, sem dúvida, a indagação feita com maior recorrência frente ao anúncio do tema de investigação deste trabalho. Respondê-la imediatamente não seria possível. Qualquer tentativa apressada poderia incorrer em equívocos. Desta forma, o princípio que norteia este capítulo é o de situar a discussão, buscando mapear a variedade de facetas que a complexifica e possibilitar recursos reflexivos para o enfrentamento do tema.

É preciso esclarecer de antemão: o trecho de abertura não necessariamente reflete, na sua totalidade, os posicionamentos deste trabalho. Contudo, ele atinge "em cheio" o cerne da questão: não é possível - em concordância com as palavras de Brandão (2005) - dividir em duas categorias estanques as posições favoráveis e contrárias ao sistema de reserva de vagas.

Dada a importância e o significado dos conceitos e princípios que embasam as propostas de implementação de cotas para acesso ao ensino superior público brasileiro, torna-se impossível separar os argumentos pró-cotas de um lado e os argumentos contra esse sistema de outro lado. (Brandão, 2005, p.95)

Nesses termos, tomar o tema como campo de análise significa adentrar necessariamente na arena de debates, onde ecoam uma pluralidade de vozes, ora dissonantes, ora consonantes, em que posições se alternam e se entrelaçam.

Há expectativas para que sejam assumidos posicionamentos definitivos frente às discussões, o que dificulta estabelecer os parâmetros de feitura de um texto sobre a presente temática. Poderíamos, neste sentido, considerar este trabalho como um "texto-militante". Ora, possivelmente ressoariam os pensamentos nada positivistas: Todo texto é, por condição, um texto-militante, uma vez que nele estão necessariamente presentes pontos de vista, ideologias, posições políticas. É como Passos e Barros (2010) nos fazem pensar quando afirmam que:

(...) podemos pensar a política da narratividade como uma posição que tomamos quando, em relação ao mundo e a si mesmo, definimos uma forma de expressão do que se passa, do que acontece. Sendo assim, o conhecimento que exprimimos acerca de nós mesmos e do mundo não é apenas um problema teórico, mas um problema político. (p.151)

Quanto a isso não há dúvidas. A expressão "texto-militante" pretende, sobretudo, sobressaltar a responsabilidade da feitura de um trabalho envolvendo tema tão espinhoso, uma vez que os usos dos discursos servirão de bandeiras nas arenas políticas e, possivelmente, nortearão ações para o enfrentamento das problemáticas suscitadas. 
Cabe salientar que o objetivo deste trabalho não é, exclusivamente, defender uma posição ${ }^{20}$, mas visibilizar os confrontos - de idéias - que têm ocorrido em vários espaços, contemplar as vozes que se conflitam nas arenas de debate, tanto nos cenários onde ocorrem as experiências, quanto fora deles.

A pergunta formulada da forma: "você é a favor ou contra as cotas?", não comporta resposta imediata. Esta impossibilidade se deve a algumas razões. Em destaque duas delas:

(1) Se a política, em fase preliminar de consolidação, exigia um debate mais profícuo que incluísse a sociedade civil mais ampla, essa exigência se coloca ainda mais na atual conjuntura, com o avançar das experiências e com a série de questões que as mesmas desencadearam.

(2) As experiências de reserva de vagas nas universidades públicas brasileiras são, hoje, realidade em muitas instituições no país. Neste caso, a urgência maior é em discutir os impasses e as estratégias de ação possíveis e escolhidas por cada instituição, com enfoque nas chamadas políticas de permanência.

Em resumidas palavras: é preciso conhecer com afinco as nuances e contradições que o tema faz/fazer antes de assumir posições simplistas. Fica, mais uma vez premente, a importância de discussões que incluam a participação de todos. É preciso que as publicações e pesquisas sobre a política e suas experiências no Brasil tenham alcances mais amplos do que os espaços acadêmicos, incluindo os veículos midiáticos.

Tomando como premissas o surgimento de novos dispositivos de ação dando maior corpo aos debates e o avançar das experiências, este texto tende, portanto, partir de um ponto mais avançado da discussão, sem perder de vista os esclarecimentos necessários para agregar os recém-chegados ao assunto.

\subsubsection{Primeiros esclarecimentos...}

(...) ainda que pareça haver uma super-representação de textos contrários nos meios de comunicação, as poucas pesquisas de opinião pública sobre o tema [ação afirmativa] mostram sua aceitação por parcela expressiva da população. Talvez, mais importante ainda do que a opinião pública é constatar que, a despeito do debate público acalorado - que tem ocorrido em ondas, normalmente seguindo notícias novas, como a criação de reserva de cotas em instituições de educação superior de prestígio, a publicação de novos dados e de análises referentes ao acesso, ao desempenho e ao perfil dos estudantes na educação superior, manifestos contra e a favor das políticas de ação afirmativa assinados por

\footnotetext{
${ }^{20}$ Embora isso seja, em certa instância, inevitável, haja vista que não há como um discurso ser absolutamente neutro.
} 
celebridades, acadêmicos e militantes, livros de divulgação bombásticos contendo previsões apocalípticas com respeito às conseqüências que as "cotas" terão para o futuro da sociedade -, em poucos anos os programas de ação afirmativa se espalharam por todo o território brasileiro. (Júnior, 2010, p.159)

De que modo se posicionar na discussão sem tender ao formato dicotômico mais freqüente? São alguns os caminhos possíveis. Um bom começo seria "desconstruir os mitos".

Na medida em que os esclarecimentos necessários não são prestados de forma cristalina, os discursos se publicizam de maneira, muitas vezes, destorcida. Alguns veículos de grande alcance social direcionam a discussão transformando suposições em verdades absolutas e fazendo prevalecer os malentendidos.

Da mesma forma que a política de ação afirmativa não é sinônimo de política de cotas (uma vez que a primeira é uma das modalidades de ação afirmativa, dentre outras existentes), esta última tampouco está restrita à política de cotas raciais. São várias as modalidades de reserva de vagas e os recortes ${ }^{21}$ são estabelecidos por cada instituição de modo particular.

\begin{abstract}
As cotas são apenas um aspecto ou possibilidade da ação afirmativa, que em muitos casos tem um efeito pedagógico importante posto que forçam o reconhecimento do problema da desigualdade e a implementação de uma ação concreta que garanta os direitos (ao trabalho, à educação, à promoção profissional) às pessoas em situação de inferioridade social. (Silva, 2002, p.108 in: Brandão, 2005, p.46/47).
\end{abstract}

Embora não estejam a elas restritas, a maior polêmica, de fato, ocorreu com a com a política de recorte racial ${ }^{22}$. Dentre as contradições e "mitos" mais propagados, sintetizam-se dois deles, nos seguintes termos: (1) as políticas de ação afirmativa, especificamente a de reserva de vagas, frente à opinião pública, enfrentam maior índice de rejeição do que de aceitação. (2) Dentre as políticas de reserva de vagas adotadas nas diferentes instituições do país prevalecem as de recorte racial.

A primeira delas é refutada por Junior (2010), através de estudo-piloto de uma coletânea de artigos reunidos no livro "Divisões Perigosas: Políticas Raciais no Brasil contemporâneo", organizado por Fry (et alli, 2007). Féres Junior (2010) seleciona 12 argumentos mais comumente utilizados em desfavor da reserva de vagas, com recorte racial. A escolha desta obra, explica Féres Júnior (2010),

\footnotetext{
${ }^{21}$ Elas podem ser de cunho racial, social, destinados aos portadores de necessidades especiais, indígenas, outros.

${ }^{22}$ Não é sem explicação, haja vista o tabu paira sobre o tema do racismo no Brasil. Deixemos pra mais tarde essa discussão.
} 
decorre, dentre outras razões, do fato de grande parte dos autores destes artigos estarem entre os "acadêmicos que têm sido muito ativos na oposição pública às políticas de ação afirmativa desde sua criação. (...)" Além disso:

Alguns dos editores do livro lideraram uma campanha contra a ação afirmativa que resultou na apresentação de um manifesto denominado Carta pública ao Congresso Nacional: todos têm direitos iguais na república democrática, ao presidente do congresso, e de um segundo manifesto, chamado Cento e treze cidadãos anti-racistas contra as leis raciais, para o Presidente da Suprema Corte Brasileira - o primeiro com a finalidade de barrar a aprovação de projetos de Lei Federal que criam programas de ação afirmativa, e o segundo visando a convencer os juízes do Supremo Tribunal Federal a declararem a inconstitucionalidade de tais políticas. (Júnior, 2010, p.160)

Ao contrário do que se poderia pressupor, "as poucas pesquisas de opinião pública sobre o tema mostram sua aceitação por parcela expressiva da população." (p.158). Féres Júnior (2010) revela dados extraídos de pesquisa realizada pelo Datafolha, em 2006, em que foram entrevistadas 6.264 pessoas, tendo revelado:

(...) um índice de aprovação de $65 \%$ para as cotas raciais e de $87 \%$ para as cotas em universidades para estudantes de baixa renda. A pesquisa também revelou que a maior parte dos defensores das cotas raciais pertence às camadas mais pobres e menos educadas da população, mas que o apoio é igual entre negros e brancos. (UOL, 2006. In: nota de rodapé, 2, Junior, 2010, p.158)

A segunda assertiva posta em questão - "Dentre as políticas de reserva de vagas adotadas nas diferentes instituições do país, prevalecem as de recorte racial” - é contradita por Paiva (2010) quando afirma que, “(...) a maior parte das políticas é reservada aos alunos da rede pública (...)" (p.10)

É provável que além destas, outras suposições sejam lançadas e tidas como fatos. O questionamento e a busca de esclarecimentos constituem caminhos ético-políticos fundamentais para o enfrentamento do tema.

É neste sentido que Vieira (2003) reivindica uma ampla discussão sobre os principais conceitos e mecanismos das políticas de ação afirmativa. A autora defende que a sobreposição de temáticas como diversidade, multiculturalismo, discriminação, diversidade acabaria incorrendo em mal-entendidos, sobretudo, “(...) a simplificação das ações afirmativas como "política de cotas" (p.87).

O alerta de Vieira (2003) se refere à possível transformação do tema ação afirmativa numa "political football", possivelmente a serviço de uma "espécie de politicagem" que, em alguma instância, advogaria contra o próprio ideal de ação afirmativa. Conclui a autora que: "a confusão formada no campo do discurso da 
ação afirmativa favoreceria sua utilização devido, não ao seu fim de igualdade, mas ao poder político ao qual estaria relacionado." (p.87)

Compreensível a preocupação de Vieira (2003). Há que se considerar, em contrapartida, que um dos feitos e efeitos mais agregadores da proposta na sua legitimação enquanto Política de Estado foi justamente o de colocar em debate as sub-temáticas tangentes ao tema mais amplo. O que está em questão não é somente uma política de reserva de vagas, mas justamente as questões que subjazem a experiência e que ficam, na maior parte das vezes, escamoteadas e invisíveis devido à ausência de debates. Resta então, como saída, os esclarecimentos em espaços de discussão.

Ainda no rastro dos mal-entendidos, a fim de clarificá-los, retomemos a questão que introduz o capítulo: "Política de cotas: você é a favor ou contra?" Ora, "cotas" são políticas de reservas de vagas, uma das modalidades de ação afirmativa. Os critérios e recortes são estabelecidos de modos particulares e são diversos. O posicionar-se diante da questão implica, acima de tudo, esclarecer outros aspectos.

Vejamos o seguinte quadro comparativo:

\begin{tabular}{|c|c|c|}
\hline \multicolumn{3}{|c|}{ A Política de Cotas na UNB, UERJ E UNEB: Quadro Compreensivo } \\
\hline UNB & UERJ & UNEB \\
\hline $\begin{array}{l}\text { Programa de cotas } \\
\text { implementado pelo } \\
\text { conselho universitário, } \\
\text { através da resolução/CEP } \\
\text { n38/2003 }\end{array}$ & $\begin{array}{l}\text { Programa de cotas } \\
\text { votado pelo conselho } \\
\text { universitário, porém } \\
\text { implementado através da lei } \\
\text { n4151/2003 }\end{array}$ & $\begin{array}{lr}\begin{array}{l}\text { Programa de cotas } \\
\text { implementado }\end{array} & \text { pelo } \\
\text { conselho } & \text { universitário } \\
\text { através de } & \text { resolução } \\
\text { n196/2002. } & \end{array}$ \\
\hline $\begin{array}{l}\text { O sistema tem } \\
\text { caráter experimental e foi } \\
\text { aprovado para o período de } \\
10 \text { anos, quando haverá } \\
\text { reavaliação }\end{array}$ & $\begin{array}{l}\text { A lei fixou o prazo de } \\
\text { avaliação do sistema de } \\
\text { cotas em } 5 \text { anos }\end{array}$ & $\begin{array}{l}\text { Não há prazo para } \\
\text { reavaliação do programa }\end{array}$ \\
\hline $\begin{array}{l}\text { Estabelece } 20 \% \text { de } \\
\text { vagas para candidatos de } \\
\text { cor preta ou parda, } \\
\text { conforme classificação do } \\
\text { IBGE }\end{array}$ & $\begin{array}{l}\text { Reserva } 45 \% \text { das } \\
\text { vagas para candidatos } \\
\text { economicamente carentes: } \\
20 \% \text { para candidatos } \\
\text { negros; } 20 \% \text { para alunos } \\
\text { oriundos das escolas } \\
\text { públicas do ensino médio e } \\
\text { deficientes físicos e e }\end{array}$ & $\begin{array}{l}\text { Reserva } 40 \% \text { das } \\
\text { vagas para candidatos } \\
\text { pretos ou pardos, oriundos } \\
\text { de escolas públicas do } \\
\text { ensino médio. }\end{array}$ \\
\hline
\end{tabular}




\begin{tabular}{|c|c|c|}
\hline & as étnicas. & \\
\hline $\begin{array}{l}\text { Além } \\
\text { autodeclaração preenchida } \\
\text { em formulário. Exige de } \\
\text { cada candidato fotografia } \\
\text { para identificação racial, e } \\
\text { homologação da inscrição } \\
\text { por meio de avaliação de } \\
\text { comissão. }\end{array}$ & $\begin{array}{l}\text { Exige autodeclaração } \\
\text { do candidato à cota racial, } \\
\text { por meio de declaração } \\
\text { escrita e assinada. }\end{array}$ & $\begin{array}{l}\text { Exige autodeclaração } \\
\text { racial através de formulário } \\
\text { escrito e assinado pelo } \\
\text { candidato. }\end{array}$ \\
\hline $\begin{array}{l}\text { Não reserva vaga } \\
\text { para alunos de escola } \\
\text { pública }\end{array}$ & $\begin{array}{l}\text { Reserva vagas para } \\
\text { alunos de escolas publicas } \\
\text { do ensino médio do estado } \\
\text { do rio de janeiro }\end{array}$ & $\begin{array}{l}\text { Inicialmente } \\
\text { reservava vagas para } \\
\text { alunos de escolas públicas } \\
\text { do ensino médio da Bahia }\end{array}$ \\
\hline $\begin{array}{l}\text { Maior repercussão } \\
\text { jurídica no problema da } \\
\text { exigência da fotografia. }\end{array}$ & $\begin{array}{l}\text { Maior repercussão } \\
\text { jurídica no problema da } \\
\text { proporcionalidade } \\
\text { razoabilidade da medida. }\end{array}$ & $\begin{array}{l}\text { Depois, foi alterado } \\
\text { para qualquer aluno oriundo } \\
\text { de escola pública, desde } \\
\text { que sejam } \\
\text { afrodescendentes. Maior } \\
\text { repercussão jurídica na } \\
\text { questão da igualdade } \\
\text { formal. }\end{array}$ \\
\hline
\end{tabular}

(Cesar, 2004, p.66)

Os dados trazidos por Cesar (2004) no quadro em destaque revelam que não somente os recortes de reserva de vagas variam como também os critérios de ingresso. É neste sentido que as posições se hibridizam e o debate se complexifica. Neste caso, em lugar da questão inicial caberia uma variedade de outras:

(1) Você é a favor da política de reserva de vagas nas universidades públicas, independente do recorte? Em caso absolutamente negativo, quais as razões? (2) Em caso de ser favorável à política, quais os grupos você consideraria justo que fossem contemplados: afro-descendentes, estudantes de escolas públicas, Indígenas, todos ou outros? (3) Se você é favorável às "cotas sociais" e contrário às "cotas raciais", quais as razões? Se você é favorável somente às "cotas raciais", quais as justificativas e que critérios seriam os melhores de modo a determinar aqueles que seriam ou não contemplados pela política: Auto-declaração, Comitê avaliativo, fotografia e/ou outros?

Considerar estas questões significa reiterar a abrangência do tema e, além disso, mostrar que as temáticas que o tangenciam estão entrecruzadas. 
Durante o processo de implementação das políticas em cada instituição, as controvérsias e conflitos se intensificaram. A todo momento, pesquisadores, integrantes de movimentos sociais, estudantes de variadas esferas da população, e outros, foram se colocando nos debates, impulsionados pelos efeitos e repercussões resultantes das experiências cotidianas vividas nestes espaços. Por esse motivo, é apropriado conhecer algumas das maiores polêmicas e os argumentos defendidos, entremeados pelos próprios acontecimentos que os desencadearam.

\subsubsection{Constitucional ou inconstitucional? Controvérsias Jurídicas e o caso da UERJ}

(...) imediatamente após a publicação dos resultados do vestibular de 2003 da UERJ, alguns vestibulandos, sentindo-se prejudicados pela aplicação desse sistema de cotas, ingressaram na justiça e obtiveram liminares (decisão judicial provisória) contra esse sistema. Alguns desses estudantes seriam aprovados caso não houvesse essa reserva de vagas estipulada pelo sistema de cotas. Outros estudantes, que também obtiveram liminares, mesmo sem a aplicação das leis que determinam a reserva de vagas, não estariam aprovados; porém alegaram que candidatos beneficiados pelas cotas foram aprovados com notas menores do que as deles. (Brandão, 2004, p.64).

Belisário (2005) é autor de um artigo intitulado "Reserva de vagas ou Garantia de vagas?", publicado em edição na revista Advir (EdUERJ), específica sobre o tema das "cotas". O autor se posiciona frente a algumas polêmicas ocorridas na experiência da UERJ, dentre as quais, a que considera a reserva de vagas concessão de privilégios aos que dela se beneficiam, usando como prerrogativa as diferentes notas dos estudantes no vestibular quando comparadas as pontuações dos ingressantes pelo sistema de "cotas" com as dos demais estudantes, nas mesmas carreiras escolhidas.

Frente à polêmica, Belisário (2005) argumenta em favor da política, quando distingue os termos "garantia de vagas" de "reserva de vagas". Vejamos de que forma:

Definindo corretamente minha posição a respeito, é importante ressaltar que, vejo de forma absolutamente clara a diferença entre reservar vagas e garantir vagas. Entendo como reserva de vagas a guarda de uma quantidade de vagas nas universidades para serem, em primeira instância, disputadas apenas por grupos claramente definidos, face à necessidade de garantirmos a estes grupos, condições minimamente semelhantes aos dos demais concorrentes à Universidade. Entendo, porém, que garantir vagas se caracterizaria como desrespeito aos direitos dos demais cidadãos, também responsáveis, em última análise, pelo financiamento das atividades dessa universidade e, que, igualmente aos que têm direito à reserva de vagas, tem direito a almejar o ingresso na UERJ. (Belisário, 2005, p.67) 
A distinção feita pelo autor conduz à reflexão sobre o significado de uma política de reserva de vagas e sobre os pressupostos capazes de legitimar juridicamente, ou deslegitimar, uma proposta desta natureza.

A definição de Jensen (2010), esclarecedora, considera "as políticas, sistemas ou regimes de cotas" como: "o estabelecimento de um número preciso de lugares ou da reserva de algum espaço em favor de membros do grupo beneficiado." (p.186).

Entre os princípios que embasam a concepção de ação afirmativa, sob a perspectiva jurídica, está o caráter de não-universalidade da política, enfatizado por Jensen (2010), razão pela qual eclodem as primeiras contrariedades nos processos de consolidação, especialmente no caso da UERJ. É como explica esta autora:

(...) pode-se sublinhar como característica das políticas de cotas a nota da nãouniversalidade. Esta não-universalidade compreendida inicialmente, quanto aos beneficiários, posto que tais medidas voltam-se especificamente para um públicoalvo determinado, identificado por características próprias que o colocam em situação peculiar de vulnerabilidade, de modo que, por definição, não podem voltar-se à totalidade, sob pena de descaracterização. (p.186)

A prerrogativa que caracteriza a política de ação afirmativa como nãouniversal se fundamenta nos significados de medidas desta natureza. Piovesan (2003 in: Brandão, 2005) destaca a provisoriedade e o caráter especial destas propostas associando-as a três distintos significados:

(...) simbolizam medidas compensatórias destinadas a aliviar o peso de um passado discriminatório; (...) uma alternativa para enfrentar a persistência da desigualdade estrutural que corrói a realidade brasileira; e por fim, permitiriam a concretização da justiça em sua dupla dimensão: redistribuição (mediante a justiça social) e reconhecimento (mediante o direito à visibilidade de grupos excluídos). (Piovesan, 2003, p.A3, in: Brandão, 2005, p.41)

Em meio às primeiras controvérsias jurídicas deflagradas pela experiência na UERJ, uma das mais freqüentes alegações no sentido de deslegitimá-la juridicamente, fora a de inconstitucionalidade da medida, decorrente da possível usurpação do princípio da Universalidade ${ }^{23}$. Para analisá-la, retomemos as três proposições significantes da medida de reserva de vagas, expressas no trecho em destaque: (1) Compensação de um passado discriminatório;

\footnotetext{
${ }^{23}$ Vale retomar os conceitos de democracia e as concepções de igualdade e de meritocracia analisados no primeiro capítulo deste trabalho.
} 
Enfrentamento da condição de desigualdade estrutural existente no país; (3) Garantia de justiça em dupla dimensão: material e simbólica.

Brandão (2003) cita Chauí (2001) fazendo uma análise crítica a respeito da chamada democracia moderna, tendo por base os pressupostos da sociedade do capital ${ }^{24}$. Ambos os autores salientam o fosso existente entre as condições ideais de igualdade (se considerados seus pressupostos basilares) e as condições reais de concretização, especialmente se considerada a realidade do Brasil. Isto significa dizer que, "igualdade formal" é diferente de "igualdade material, efetiva". (p.41). O paradoxo que se estabelece entre as duas formas de igualdade descritas é salientado por Chauí e Brandão (2001 e 2005) no seguinte sentido:

\begin{abstract}
A autora [Chauí] considera que a democracia é uma forma sociopolítica definida pelo princípio da isonomia - todos os cidadãos são iguais perante a lei - e pelo princípio da isegoria - direito e liberdade que todos têm de expressar publicamente suas opiniões. Para Chauí, o maior problema de uma democracia numa sociedade dividida em classes sociais é a manutenção desses princípios (igualdade e liberdade) com os efeitos da desigualdade presente na mesma, a desigualdade real. (Brandão, 2001, p.41)
\end{abstract}

Cesar (2007) aposta na constitucionalidade da política analisando o princípio da igualdade e diferenciando "igualdade perante a lei no ordenamento jurídico" de "igualdade na letra da lei". O autor entende que o princípio da igualdade, na história republicana brasileira, se apresenta mais na sua dimensão ausente do que presente. Em vista disso, associava-se "menos com o que igualava e muito mais com o que desigualava, menos com o que afirmava e mais com o que negava na realidade do país." (p.20)

Que prevalece na realidade brasileira uma desigualdade que se distancia dos cânones de uma "igualdade formal" é sabido. As considerações feitas no capítulo anterior subsidiam esta discussão e ilustram esta assertiva. O que se pretende analisar, desta vez, são os fundamentos jurídicos usados para fazer das políticas de ação afirmativa medidas constitucionais, portanto, legítimas sob o formato de Política de Estado, assim como, mapear as alegações que as deslegitimam, usadas pelos que se posicionam contrários à proposta. Jensen (2010) contribui para clarificar alguns destes aspectos.

Considerando o termo "ação afirmativa" também como "discriminação positiva", enfatizando o sentido de "discriminação" na sua acepção mais original expressa nas palavras "discriminar (...) distinguir, diferenciar" (p.132), estas

\footnotetext{
${ }^{24}$ Tema já amplamente discutido no capitulo 1.
} 
terminologias - ação afirmativa e discriminação positiva - significariam "desigualdades para promover a igualdade, atribuindo a alguns um tratamento preferencial (...)" (p.133). Tomando, ainda, como parâmetro a expressão "discriminação positiva", Jensen (2010) e outros autores "vislumbram nas ações afirmativas um princípio de concreção da igualdade material" (p.133). A autora explica, com Villenave, que esta concepção:

Tem o mérito de contemplar a finalidade genérica perseguida - restabelecimento de uma igualdade de oportunidades comprometida por desigualdades de fato - e o meio ou médium para atingir tal finalidade - a instituição de tratamentos diferenciados, ou em outras palavras, a instauração de seletividade. (2010, p.134)

A condição de desigualdade estrutural brasileira ${ }^{25}$ estaria, então, intimamente relacionada às duas dimensões de injustiça anteriormente referenciadas: a injustiça material e a injustiça simbólica. Dito isto, Salvador (2008) estabelece duas formas de desigualdade existentes no país: a desigualdade econômica e a desigualdade social. A primeira "se concretizaria através da redistribuição de renda" enquanto a segunda "estaria voltada para a redução das desigualdades sociais, baseadas em aspectos identitários e culturais" (Salvador, 2008, p.29).

Seguindo esta linha de raciocínio, as políticas públicas com vistas a solucionar a desigualdade material (ou econômica) seriam consideradas "políticas de redistribuição" e as com vistas a minimizar a desigualdade social (ou cultural) seriam as "políticas de reconhecimento". (p.29) ${ }^{26}$

Salvador (2008) analisa o caso brasileiro, defendendo que, apesar de, historicamente, haver certa tendência em privilegiar políticas de cunho universal, com caráter redistributivo, "há demandas tanto por redistribuição quanto por reconhecimento" (p.29) Neste sentido, esta autora entende que as polêmicas geradas em função da implementação da política de reserva de vagas nas universidades públicas decorrem do fato de estarem vinculadas "à redistribuição, porém considerando a falta de reconhecimento de direitos de grupos específicos" (p.29)

Com base nas considerações precedentes, a alegação de inconstitucionalidade pode ser posta em cheque quando se considera que a seletividade é um recurso jurídico legítimo para correção das desigualdades. Contudo, explica Jensen (2010), a discriminação positiva (ou ação afirmativa)

\footnotetext{
${ }^{25}$ Melhor seria dizer iniqüidade, pautando-se em alguns autores que privilegiam o termo equidade em detrimento de igualdade.

${ }^{26}$ Salvador, 2010, p.29 cita Fraser, 2001.
} 
precisa de alguns elementos para que seja considerada medida constitucional, sendo eles: "O fundamento do discrímen (ou justificativa), a proporcionalidade e a temporariedade" (2010, p.140).

Com a vez o fundamento ou justificativa da medida: É preciso que se clarifiquem os critérios que fundamentam ou justificam o uso do recurso seletividade de forma a garantir que a política de reserva de vagas seja considerada constitucional.

\begin{abstract}
É essencial que a distinção ou política diferencial seja orientada por um critério fundamento do discrímen - ou justificativa do tratamento diferenciado - cuja natureza permite fazer vislumbrar que a política em questão persegue uma finalidade legítima, qual seja, a minimização ou superação de uma situação de vulnerabilidade originada por um quadro de desigualdade injustificada ou de discriminação, presente ou passada. (...) qualquer seletividade que não seja nitidamente voltada a promover melhor representação de determinados grupos vulneráveis na participação de bens ou recursos, a proporcionar uma maior igualdade de oportunidades ou diminuir discriminações odiosas por eles sofridas, atuais ou passadas, enfim, minorar e combater uma situação de vulnerabilidade, fatalmente caracteriza, em verdade, uma discriminação odiosa, maculada de ilegitimidade e inquinada de inconstitucionalidade. (Jensen, 2010, p.140)
\end{abstract}

As palavras de Cesar (2004) endossam a assertiva que defende a constitucionalidade da política de cotas, na medida em que apontam os preceitos-base dos ideais republicanos que pautam a Constituição Federal Brasileira. Argumenta o autor que as "cotas" não são privilégios, mas apenas uma forma de minimizar as disparidades sociais existentes no país. Afirma ainda que "essa desigualação é apenas um meio de superar diferenças que promovem relações de domínio e poder entre pessoas e situações sociais (...)". Completa que,

(...) a ação afirmativa não se constitui um princípio constitucional propriamente dito, mas recebe pleno amparo constitucional para ser implementada, na modalidade jurídica da República Brasileira, que visa combater as desigualdades mais gritantes que afetam as minorias brasileiras, como é o caso da minoria racial. (Cesar, 2004, p.27)

Cesar (2007) contradiz a prerrogativa que considera a reserva de vagas uma concessão de privilégios além de fator agravante de discriminação. Argumenta o autor que, "privilegiar significa tratar com regalias setores que por si sós já se diferenciam do todo por terem mais acesso a bens, direitos e recursos do que outros." Assim sendo, "não há que se considerar aqui adoção de ações afirmativas como privilégio de proscrição do princípio republicano, e sim, a reafirmação desde princípio, uma vez que elas atendem ao objetivo fundamental 
da nossa República que é o de promover a justiça social e de alcançar uma sociedade solidária." (p.21)

Até o momento, foram tratados os parâmetros jurídicos tangentes à proposta, ponto em relevo as condições de desigualdade - desigualdade real que engloba as dimensões material e simbólica - que prevalecem no âmago da sociedade brasileira. Quando se trata de estabelecer os grupos que são afetados por essa condição de desigualdade e que, por essa e outras razões, devem ser contemplados por medidas de cunho afirmativo, a discussão toma novos rumos.

Considerando as ações afirmativas medidas direcionadas a grupos em situação desprivilegiada, seja do ponto de vista material seja em decorrência de outros privilégios ausentes, a política poderia ser definida por:

Todos os tratamentos preferenciais outorgados pela Constituição Federal, legislação, administração pública, ou mesmo entes particulares, a determinados indivíduos, grupos ou mesmo em territórios em virtude de sua condição peculiar de vulnerabilidade, oriunda de discriminação, desigualdade ou outros fatores sociais ou naturais. (Jensen, 2010, p.138)

Entretanto, alguns entraves se colocam. Para que um grupo seja contemplado por uma medida de discriminação positiva é preciso que seja justificada sua condição de desigualdade e de vulnerabilidade e que sejam estabelecidos critérios para definir estas condições. Além disso, também é preciso que se torne claro em quais grupos os indivíduos se enquadrariam para que, juridicamente, possam ser beneficiados pela política em questão.

Salvador (2008) entende que a linha divisória entre as coletividades são tênues, especialmente quando está em questão a realidade brasileira. A autora argumenta que a condição de desigualdade não se restringe à divisão de classes e às questões econômicas uma vez que a análise deve considerar também outros fatores, como "gênero, sexo, raça, etnia(...)". (p.28)

(...) desvantagens econômicas e desrespeito cultural estão entrelaçados e apoiando um ao outro" (p.246) (...) para Fraser, as coletividades são ambivalentes porque sofrem, ao mesmo tempo, injustiças ligadas à esfera econômica e cultural e, por isso, necessitariam de remédios redistributivos e de reconhecimento. (...) Ninguém é integrante de uma só coletividade. (Salvador, 2008, p.32/33)

A autora conclui que: "Não se pode pensar em políticas de igualdade sem que sejam reconhecidas as diferenças, uma vez que tanto a má distribuição quanto o não reconhecimento geram desigualdade". (2008, p.33) 


\subsubsection{Cruzando o critério social com o critério racial}

O primeiro sistema de reserva de vagas, na sua natureza experimental, apresentava sérios problemas para a sua implementação. Além de ter perpassado o crivo da autonomia universitária, a Lei Estadual 3.524/2000, em seu art.2, I, a, reservava $50 \%$ das vagas, em cada curso de graduação das universidades fluminenses, para candidatos que durante toda a vida escolar estudaram em escolas públicas do Estado do Rio de Janeiro. Por sua vez, a Lei estadual $3.708 / 2001$, art. 1 , reservava $40 \%$ de vagas nos cursos de ambas as instituições, para negros e pardos. Como as cotas reservadas para cada modalidade eram sobrepostas, na aplicação das duas leis, primeiro preenchia-se o percentual de $50 \%$ pelos candidatos aprovados no vestibular, verificando-se em seguida, se dentre os alunos aprovados neste percentual da escola pública havia candidato que se autodeclarou negro ou pardo para que fosse preenchida a segunda cota racial de $40 \%$." (...) isso agravou-se quando dentre os candidatos aprovados pela reserva de escola pública não havia, na maioria dos cursos, o percentual esperado de candidatos autodeclarados "negro" ou "pardo". Caso em que a composição do percentual da cota racial, estabelecido em lei, deveria ser preenchida por candidatos autodeclarados como tais oriundos de escolas particulares. Isso significava que, além do percentual de $50 \%$ poderia existir um acréscimo de até $40 \%$, Isto é, de até $90 \%$ na composição das vagas existentes para cada curso nas duas universidades (...) Assim a política de ação afirmativa que deveria ser a exceção da regra, tornou-se a própria regra. (Cesar, 2007, p.16)

Antes de mais nada, a descrição nos encaminha a analisar outros fatores de garantia da constitucionalidade da política de ação afirmativa: a proporcionalidade e a razoabilidade da medida. Cesar (2004) elenca três elementos fundamentais:

(1) A pertinência ou aptidão, a qual determina se a medida constitui o meio apropriado para alcançar o fim objetivado pelo interesse público. (...) (2) necessidade, o qual implica tanto no convencimento de que a medida é necessária, como também de que ela não excederá os limites a que se propõe alcançar. (3) proporcionalidade "strictu senso", recai sobre a análise, no caso específico, dos meios ou mecanismos adotados na persecução do interesse disputado entre grupos de pessoas ou indivíduos (...). (Boanevides in: Cesar, 2004, p.45)

O que a experiência relatada leva a crer é que, uma vez implementada pelo Estado, a política trouxe antes de tudo contradições, parte delas em razão das características sócio-culturais brasileiras, que encaminham um cenário de desigualdade de condições que acometem grupos distintos, cujas coletividades, como defende Salvador (2008), se hibridizam arrefecendo a linha divisória capaz de diferenciar os grupos e de estabelecer em quais deles situam-se os sujeitos. As contradições também aconteceram em função da relação entre a justiça, na sua perspectiva universalista e a sociedade, na realidade concreta. Para que uma medida seja considerada constitucional é preciso adequação desta realidade ao que preconiza a legislação, o que implica em não tomá-la de forma literal, mas em analisá-la segundo o contexto de implementação. 
As ponderações de Cesar (2004) vão ao encontro desta discussão, quando salientam a eficácia do sistema de caráter universal, num contexto "cuja distribuição de bens e direitos já se encontra um perfil equitativo e homogêneo", - que não ocorre em sociedades como a nossa, em que prevalecem desigualdades que, segundo o autor, se agravam ainda mais em função justamente de políticas de caráter universalista.

Em um país cuja história é ameaçada pelo regime escravocrata, comenta Cesar (2007), como no caso brasileiro, "não basta apenas distribuir direitos e bens através de políticas universalistas, principalmente, porque o Estado estará transferindo a responsabilidade da inclusão, ou da eficácia da medida, para os grupos excluídos (...)" (p.18)

No sentido de tornar a medida constitucional e de equilibrar o percentual desproporcional que prevalece nas primeiras experiências, tal como se verifica na descrição de Cesar (2007), uma nova lei (4151/2003) é aprovada marcando uma segunda etapa das ações afirmativas nas instituições de ensino superior fluminenses. A legislação que substituiu a anterior prevê, desta vez, a reserva de:

$45 \%$ das vagas para alunos carentes de cada curso de graduação, distribuídas do seguinte modo: $20 \%$ das vagas para estudantes oriundos da rede pública de ensino; $20 \%$ para negros; $5 \%$ para pessoas com deficiência física, juntamente com integrantes de outras minorias étnicas. (p.17)

As controvérsias continuam na medida em que as políticas se configuram nas demais instituições. Vejamos o caso da UNEB.

\title{
3.3.4 Proporcionalidade e razoabilidade: $O$ caso da UNEB
}

\begin{abstract}
Considerando que entre a população residente na Bahia, os afro-descendentes (pretos e pardos) representam, segundo dados recentes do IBGE, 74,95\%, conclui-se que o número de candidatos que fizeram opção pelas cotas ficou aquém do que se poderia esperar. Não obstante os inúmeros fatores que nos autorizariam a especular acerca das razões desta baixa procura há uma hipótese bastante provável. O tempo relativamente curto que decorreu entre a edição da medida na Uneb e a inscrição para o vestibular - mais ou menos 3 meses somado à controvérsia que envolveu a opinião pública nacional diante da inédita possibilidade dos afrodescendentes ingressarem nas universidades públicas em contingentes consideráveis, concorreu para que as informações, embora divulgadas de maneira adequada, não fossem suficientemente analisadas pelos interessados no que diz respeito à sua legalidade e legitimidade. (p.203)
\end{abstract}

Os relatos de Mattos (2004) apontam as tensões vivenciadas no momento preliminar de consolidação da política de reserva de vagas, na Universidade do Estado da Bahia. Várias questões vêm à tona, a partir deste acontecimento. 
Uma delas refere-se às controvérsias geradas pela escolha da raça como critério para reserva de vagas no ensino superior.

A partir desta perspectiva, o que se verifica é que as políticas de reserva de vagas, para serem legitimadas juridicamente, precisam ser formatadas segundo as características de cada região. Avalia-se, então, a proporção e o perfil de cada população, tendo em vista a variabilidade existente entre as regiões dentro do território Nacional, tanto quantitativamente quanto no que se refere aos percursos históricos e processos de aculturação de cada uma delas. A política de reserva de vagas leva em conta as peculiaridades regionais e a avaliação da experiência também implica em mapear histórico-politicamente cada um dos contextos de implementação.

O trecho de abertura deflagra, ainda, questões: A condição de desigualdade social, relacionada à baixa qualidade de ensino das escolas públicas, é coincidente com a condição de desigualdade racial do país? De outra maneira: A desigualdade de classes é coincidente com a desigualdade racial? Solucionar estas questões implica em analisar mais detidamente as peculiaridades do caso brasileiro.

Mattos (2004) explica que a política de reserva de vagas na UNEB privilegiou o entrecruzamento dos fatores social e racial. ${ }^{27} \mathrm{~A}$ opção pela mistura dos dois critérios decorre, sobretudo, da tentativa de garantir que os estudantes concorram em condições equânimes, especialmente considerando as desigualdades no acesso à educação formal de base, entre a rede pública e privada.

Considerando a existência de estudantes negros que, porventura, possam ter tido acesso às boas instituições educacionais, o entrelaçamento dos dois critérios visaria garantir que os estudantes provenientes de escolas públicas não concorressem com os primeiros. Enfim, o objetivo - esclarece o autor-, seria "impedir que candidatos afro-descendentes que tiveram a oportunidade relativamente privilegiada de estudar em escolas privadas - que pelo menos em Salvador, não é tão raro, apesar de ser minoritário - disputem os $40 \%$ de vagas do sistema de cotas com os candidatos afro-descendentes que estudaram em escolas públicas". (p.203)

A opção pelo recorte social e racial tendo por base a justificativa de equiparar as desigualdades decorrentes do ensino público de base se aproximaria da chamada política de redistribuição, ou seja, o objetivo da reserva

\footnotetext{
${ }^{27} \mathrm{O}$ que significa que o candidato à reserva de vagas para afrodescendentes também deveria ter cursado seu ensino médio na rede pública de ensino.
} 
de vagas seria o de possibilitar o acesso equânime dos estudantes e sua possível ascensão social e econômica pelo viés educativo. Estabelecido deste modo, o critério racial, isoladamente, não se sustentaria.

Há quem defenda que a política destinada aos alunos provenientes de escolas públicas cumpra a função de garantir uma equiparação, solucionando, inclusive, a exclusão da população afrodescendente dos espaços educacionais de ensino superior. Se partirmos do princípio de que a maior parte da população afrodescendente do Brasil é também a que possui menor acesso à educação de qualidade, a opção do critério sócio-econômico, especialmente com uma trajetória educacional prevalecente na rede pública de ensino, seria privilegiada.

A assertiva acima justifica o critério "carência ${ }^{28 "}$ como recorte para a reserva de vagas nas universidades públicas. As análises feitas no primeiro capítulo referentes à educação no Brasil, nos seus processos de exclusão/inclusão, corroboram o quadro de desigualdade, mais propriamente, de falta de oportunidades, que colocam alguns estudantes em situação desvantajosa na concorrência com outros mais favorecidos. Esta discussão se alinha ao conceito de meritocracia, um dos argumentos usados para deslegitimar a política de cotas nas universidades brasileiras.

Frei Davi no artigo de título "Cotas: Atos de exclusão substituídos por atos de inclusão" questiona o conceito de "mérito", distinguindo-o ao de "capacidade". Argumenta que: "Se colocarmos duas pessoas para disputar uma corrida, e para uma dermos acesso aos melhores treinadores, a uma boa alimentação, equipamento técnico e deixarmos a outra abandonada à própria sorte, quem vai ser a vencedora?" (2004, p.183). Santos (2004) distingue "capacidade" de "saber acadêmico" argumentando que os estudantes que tiveram maior acúmulo de saber sobressaem na seleção para o ingresso nas universidades públicas, o que não significaria demérito.

O vestibular deve medir capacidade e não acúmulo de saber acadêmico, e o Estado deve investir com coragem na melhoria do ensino público fundamental e médio. Como consertar o estrago dos que já saíram do ensino médio? (p.184)

As políticas de ação afirmativa, no caso brasileiro, defende o autor, seriam importantes estratégias se aliadas à melhoria do ensino educacional de base, sobretudo o da rede pública.

\footnotetext{
${ }^{28}$ O termo carência é usado pra designar aqueles que possuem condições sócio-econômicas desfavorecidas e que estudaram nas escolas publicas no ensino médio, no caso do recorte para reserva de vagas.
} 
Dados bastante representativos da disparidade acima descrita são extraídos do perfil dos candidatos na relação com as escolhas pelas carreiras menos e mais procuradas nestas universidades. Analisando pesquisas feitas nestas instituições, quase todas indicam que, nos cursos considerados de maior prestígio social e que significariam maior possibilidade de ascensão econômica, ingressam os estudantes que tiveram acesso às melhores instituições educacionais de base: a rede privada. A relação candidato-vaga determina não somente a escolha das carreiras pelos estudantes, mas também seleciona o perfil dos que provavelmente seriam aprovados.

Vale considerar que, as mesmas estatísticas que indicam a disparidade de estudantes com condições menos e mais favorecidas economicamente (expressos nas hierarquias dos cursos no que diz respeito ao maior prestigio e status social), apontam diferenças dentro das classes menos favorecidas.

Esta constatação vai ao encontro das reflexões feitas por Salvador (2008) quando afirma a existência de ambivalência das coletividades. (p.32) A autora defende a articulação entre políticas de reconhecimento e políticas de redistribuição, uma vez que um indivíduo pode sofrer discriminação de várias ordens: econômica, social, cultural. Argumenta a autora: "uma mulher negra oriunda de classe popular, que luta pelo reconhecimento de sua identidade de mulher e negra, necessita também de políticas distributivas, relativas à sua situação de marginalização econômica". (p.32)

As últimas ponderações direcionam a discussão para a temática de maior repercussão: a política de cotas com recorte racial.

\subsubsection{As cotas raciais e o debate: Balanços preliminares a partir da política na UERJ}

A leitura dos dados comprova a correlação entre o desempenho do candidato e o nível de escolaridade e renda da família e permite concluir que fatores socioeconômicos produzem, efetivamente, desigualdades educacionais que se manifestam no desempenho obtido no Vestibular. Tais desigualdades não se vinculam, necessariamente, à natureza da escola que freqüentaram, mas às diferentes possibilidades de vivência educacional. Dentre todos os fatores analisados, a renda familiar é a de maior impacto sobre o desempenho, seguida diretamente da escolaridade do pai. O nível de desempenho é inversamente proporcional ao ingresso no mercado de trabalho, visando ao aumento da renda familiar. É sobre os estudantes negros que as questões se abatem de modo mais avassalador. Os fatores já apontados justificam tanto adoção de cotas sociais vinculadas à condição de carência - quanto o estabelecimento de subgrupos no interior das cotas. (Villardi \& Amadei, 2007, p.38) 
Estas informações foram obtidas em pesquisa feita pela professora da Faculdade de Educação e por uma das coordenadoras da Sub-Reitoria de Graduação $^{29}$, ambas da UERJ. Na pesquisa, as autoras apresentam alguns dados referentes ao perfil socioeconômico dos estudantes ingressos pelo sistema de cotas nesta instituição, sinalizando a existência de diferentes perfis no interior da própria categoria "carentes", permanecendo os negros nas posições menos favoráveis. Esta é uma das razões usadas em defesa do recorte racial como critério.

O debate ganha novos contornos na medida em que outras justificativas são usadas em favor do sistema de cotas raciais. Alguns destes discursos estão sintetizados nas assertivas a seguir:

A política de reserva de vagas para afrodescendentes: (1) Configura-se como medida de redistribuição, se considerado que os negros possuem condições sócio-econômicas inferiores às dos brancos. (2) Apóia-se na condição desprivilegiada social e economicamente dos negros, mesmo quando comparados aos brancos pobres. (3) Justifica-se em função do pagamento da dívida histórica para/com esta população em função de um passado escravocrata. (4) Se fundamenta numa política de reconhecimento e, numa perspectiva de afirmação identitária, com vistas à diminuição do preconceito e da discriminação. (5) É uma tentativa de promover uma sociedade multicultural, numa perspectiva pluriétnica.

As afirmativas (1) e (2) analisam o aspecto "pobreza" e o critério racial em relação. Especificamente a assertiva (2) aponta condições desiguais dentro da camada social menos favorecida, onde os negros ocupariam posição de maior desprivilegio frente aos demais. Estes dados seriam indicativos de condições desiguais referentes não somente a uma divisão de classes sociais, mas, sobretudo, de etnia.

Salvador (2008) usa a expressão "embranquecimento da riqueza", referenciada em Henriques (2001). Conforme dados apresentados por este último autor:

Os negros em 1999 representavam 45\% da população brasileira, mas correspondem a $64 \%$ da população pobre e $69 \%$ da população indigente. Os brancos por sua vez, são $54 \%$ da população total, mas somente $35 \%$ dos pobres e $31 \%$ dos indigentes. (Henriques, 2001 in: Salvador, 2008, p.26)

De fato, é como defende a autora:

\footnotetext{
${ }^{29}$ Raquel Villardi e Stella Maris Amadei, respectivamente.
} 
Não há uma situação de pobreza descolada de uma situação de discriminação de gênero, étnica, religiosa, regional. O que importa destacar é a existência de uma nítida hierarquia de discriminação no interior da pobreza. (Henriques, julho, 2001 in: Salvador, 2008, p.26)

Verifica-se, até o momento, uma disparidade nas condições sócioeconômicas de negros e brancos, refletidas nas estatísticas apresentadas pelos autores. O que é possível constatar é que, muitos dos discursos em defesa das cotas raciais entendem como necessária a confluência das variáveis etnia e condição social. Vejamos em que sentido:

Vieira (2003) observa que os índices das pesquisas oficiais do governo apontam a existência de trajetos desiguais nos processos de formação educacional da população se comparado os dos "brancos" com os dos "afrodescendentes". A origem destas diferenças decorreria dos resquícios de um passado escravocrata e de um sistema de ensino desigual qualitativamente. Dentre os motivos, a autora atribui: ao crescente processo de "urbanização e industrialização aceleradas" que, em lugar de minimizar as desigualdades, "ampliaram suas desvantagens, alocando-as [a população negra] nas piores posições" nas áreas de educação, mercado de trabalho, distribuição de renda, entre outras. (p.85)

Dentre estas desvantagens, Vieira (2003) destaca a evasão escolar em proporção considerável (com trajetos marcados por repetências, atrasos, etc.), cuja razão deve-se a, principalmente, dois aspectos:

\begin{abstract}
O primeiro, diz respeito a aspectos de identidade, socialização e reprodução de estereótipos que apontam para a estrutura dos currículos escolares ao excluir da grade a história e cultura negra'(...), onde os brancos são percebidos como tendo qualidades positivas em detrimento de qualidades negativas apontadas para negros. (p.85) (Hasenbalg, 1990, p.6 in: Vieira, 2003, p.85)
\end{abstract}

O segundo aspecto - a baixa condição financeira - poderia estar relacionado não somente às qualidades das escolas de base, mas tanto à "segregação geográfico-espacial/racial" quanto à evasão escolar dos estudantes negros, em função da necessidade de ingresso no mercado de trabalho. (p.85)

Não se trata apenas de nivelar negros e brancos para que possam empreender uma justa competição. Apesar de considerar a existência de um vácuo entre a capacidade de disputa entre os dois grupos, compreende-se que as diferenças socioeconômicas entre ambos são geradas não somente pela falta de habilidades competitivas, mas também pela adoção de padrões seletivos desiguais, baseados em critérios racistas, que explicam, entre outras coisas, como negros com diploma universitário ganhavam um salário inferior ao dos brancos com diploma de segundo grau, para as mesmas funções. (Walters, 1995, in: Vieira, 2003, p.87) 
O termo discriminação, mais usualmente associado a uma forma mais explícita de preconceito, ganha em Vieira (2003) um sentido mais abrangente. A condição de desprivilegio que hierarquiza a "classe pobre" brasileira, conferindo aos negros as piores posições dentro desta pirâmide, também se caracterizaria por discriminação e o fato de grande parte da população que dela sofre não considerá-la como tal, seria obstáculo para o enfrentamento da problemática, segundo acredita esta autora. (p.88)

Hasenbalg (1979) analisa a história da população afrodescendente no Brasil, abordando os efeitos da escravidão e o modo como os processos de aculturação ocorreram neste país. Sob o título "As armas ideológicas: o branqueamento e o mito da democracia racial', o autor localiza os negros brasileiros em posições inferiores, do ponto de vista social e político, ao longo deste processo e pontua alguns aspectos que contribuíram para a desmobilização política do movimento negro, que reverberaram nos dias atuais.

A industrialização e urbanização, processos que a economia brasileira atravessa após 1930, especialmente na região sudeste do país, conferiram certo destaque a uma pequena elite de negros que, naquele contexto, puderam ascender, tendo sido incorporados à "classe trabalhadora industrial" da época. Hasenbalg (1979) aponta os integrantes deste grupo como os possíveis líderes, tendo sido eles, provavelmente, os protagonistas "das raras manifestações de não-conformismo racial durante as últimas décadas"30 ${ }^{\text {" }}$ (p.250)

No entanto, Hasenbalg (1979) realça um quadro de isolamento social do grupo, à época, em função "de seu desvinculamento da massa de negros e seu restrito acesso social aos brancos de posição social semelhante" (p.250) É neste sentido que se verifica uma sobreposição da identidade de classe sobre a identidade racial.

Se uma orientação individualista para com a mobilidade social ascendente é típica da pequena classe média de não-brancos, de um ponto de vista político a predominância da identidade de classe sobre a identidade racial é talvez a característica mais relevante dos negros e mulatos da classe operária urbana. (p.251)

\footnotetext{
${ }^{30}$ Não é sem sentido que Mattos (2003) coloca em relevo o ingresso no ensino superior como um importante veículo de "desencadeador de desenvolvimento social e de expansão da cidadania na medida em que possibilita a formação de individualidades independentes e autônomas" além "dos efeitos sociais repercutirem positivamente nos âmbitos coletivos onde, necessariamente, se inserem as individualidades: a família, a comunidade, a região e, no limite, a própria nação". (p.136)
} 
De volta à contemporaneidade, a menção de Vieira à expressão "centopéia de duas cabeças" - de Santos (1996) - faz referência ao duplo formato de discriminação que afetava muitos negros brasileiros, em razão de não reconhecerem como preconceito as situações de opressão e de desigualdade a que muitos deles eram acometidos, além, em alguns casos, deles próprios "desenvolverem uma imagem negativa" de sua raça. (p.88)

As palavras de Vieira (2003) colocam em reflexão um dos grandes argumentos usados em desfavor das cotas com recorte racial: a premissa de que o Brasil, se comparado a outros países (caso dos EUA e África do Sul), não seria um país racista. A autora usa a expressão "paraíso racial" referindo-se à suposta crença de que, em território brasileiro, experimenta-se uma "democracia racial". A este respeito, comenta Vieira:

\begin{abstract}
Um outro problema a ser resolvido refere-se ao Brasil perceber-se como "o espelho dos outros", pois quando comparado com sociedades de tradição segregacionista(...) é visto como um paraíso racial. Fato que é reforçado pela grande integração cultural do País, já que a absorção de modelos culturais africanos, especialmente a dança e a música, e a ascensão de alguns ícones pela via das artes e do esporte, obscurece a lacuna que existe no que se refere à integração social não-igualitária de negros e brancos. E ainda reforça a falsa idéia [Vieira, 2001] de que, de fato, artes e esportes(...) configuram-se como a principal, se não é única, via de ascensão para a população negra, em detrimento da educação formal (...). (2003, p.88)
\end{abstract}

As palavras de Hasenbalg (1979), anteriores, ressoam nas de alguns defensores da política de reserva de vagas para negros nas universidades, quando consideram o chamado "mito da democracia racial" um dos maiores entraves para mobilização política dos negros brasileiros, tanto quanto para a legitimação de propostas e/ou políticas de caráter afirmativo nos diferentes âmbitos societários. Este autor fala de um "ideal de branqueamento" (p.240) que vem processualmente se desenvolvendo na cultura brasileira há tempos e que:

Funcionou como reforço simbólico do mecanismo pelo qual... a existência de oportunidades de mobilidade social individual induz um calculo racional ao negro segundo o qual suas oportunidades de ascensão são estimadas como estando em proporção inversa à sua solidariedade étnica. (...) se o ideal de branqueamento transformou-se na sansão ideológica do contínuo de cor desenvolvido durante a escravidão, o mito da democracia racial brasileira é indubitavelmente o símbolo integrador mais poderoso criado para desmobilizar os negros e legitimar as desigualdades raciais vigentes desde o fim da escravidão. (p.241)

Analisemos dois aspectos trazidos na citação: a manutenção de um mito que invisibiliza a existência do racismo no Brasil e a representação simbólica da 
origem negra na sociedade brasileira associada a conotações de cunho negativo.

Para análise do segundo aspecto, vale retomar os paradigmas que norteiam o multiculturalismo no $\mathrm{Brasil}^{31} \mathrm{e}$ as variadas acepções existentes em torno do termo "raça". É preciso relembrar que, as idéias multiculturais se amplificaram no país impulsionadas pelo movimento negro, incluindo, dentre as proposições, a derrubada do mito da democracia racial no Brasil e as mudanças de paradigmas e representações sociais que conferiam estereótipos de inferioridade à raça negra e de superioridade à raça branca. Nestes termos, os princípios que norteavam as ações do movimento pautavam-se na afirmação da cultura negra e na aniquilação de um possível complexo de inferioridade que marcaria os processos de aculturação afrodescendentes.

Partindo do entendimento de que este movimento, numa perspectiva intermulticultural atua, de início, numa dimensão político-ideológica - especialmente nas instituições educativas e na sociedade, mais amplamente - Candau (2008), ao mesmo tempo em que realça a importância de ações desta natureza nestes espaços, destaca a insuficiência das mesmas e a necessidade de que sejam implementadas "políticas públicas e institucionais que viabilizem na prática um projeto de sociedades multiculturais, que inclui necessariamente a promoção de uma educação que leve em consideração essa realidade." (p.93)

Assumir que o Brasil é de fato um país racista, pondo em cheque o mito de uma sociedade democrática, do ponto de vista da racial, possibilita perceber, como diz Candau (2008): "o caráter discriminador, hierarquizador, autoritário e de negação do "outro" na nossa sociedade". (p.93) Nesta linha de análise, a autora defende que:

\footnotetext{
Somente assumindo de modo consciente e crítico processos de hibridização cultural presentes na sociedade brasileira e favorecendo o diálogo intercultural seremos capazes de promover processos educacionais que articulem igualdade e diferença, universalismo e relativismo e globalização e pluralidade cultural no nosso contexto. (p.93)
}

Na medida em que políticas públicas se misturam às ações sociais com o fim de transformação pelo viés cultural, as discussões sobre concepções de raça e identificações dos grupos étnicos ganham espaço. O debate alcança o auge de sua repercussão quando o critério racial, uma vez estabelecido como recorte das políticas de reservas de vagas em universidades, exige que se objetifiquem

\footnotetext{
${ }^{31}$ Tratado mais pormenorizadamente no capítulo 1.
} 
parâmetros de definição. É o que se pode verificar com a experiência da UnB, através dos relatos de Maio e Santos (2005, p.193).

\title{
3.3.6 O critério "raça" e as tensões suscitadas: Os Casos da UNB e da UERJ
}

\begin{abstract}
Os responsáveis pelo vestibular da UnB por diversas ocasiões reiteraram que a meta da comissão era a de analisar as características físicas, visando identificar traços da raça negra. Esse objetivo gerou constrangimentos diversos e dilemas identitários de não pouca monta entre os candidatos ao vestibular, devido às dúvidas se os critérios seriam mesmo o de aparência física (negra) ou de (afro)descendência. A candidata A. P. L. P., à princípio na dúvida sobre se se declararia "negra", foi convencida pelo argumento da mãe, que lhe disse que sua "tataravó era escrava". Contudo, ainda assim, A. P. estava preocupada pois, segundo ela, "pela fotografia não dá para analisar a descendência ". Outra candidata, E. B.,que não se intimidou com a fotografia, comentou: "Minha irmã não seria considerada negra, por exemplo. Ela é filha de outro pai, tem a pele mais clara e o cabelo mais liso" (Borges, 2004) R. Z., um candidato que se declarou "negro", ainda que "com a pele clara, cabelo liso e castanho... nem de longe lembra[ndo] um negro", e cuja classificação não foi aceita pela Comissão, afirmou: "vou levar a certidão de nascimento de meu avô e mostrar a eles... se meu avô e minha bisavó eram negros, eu sou fruto de miscigenação e tenho direito. (Paraguassú, 2004 in: Maio e Santos, 2005, p.193)
\end{abstract}

Vários foram os impasses enfrentados no momento em que eram estabelecidos os critérios através dos quais seriam selecionados os estudantes que poderiam concorrer às vagas reservadas no processo seletivo do vestibular. As maiores tensões eclodiram, em maioria, nas universidades que adotaram o recorte racial como critério, o que explica, em parte, a grande repercussão envolvendo a política de ação afirmativa no país.

Tendo em vista que cada instituição adotou seus próprios critérios, ${ }^{32}$ as controvérsias surgem, também, de modos particulares em cada uma delas.

\begin{abstract}
A variação principal está no procedimento de identificação, onde há o predomínio do uso da auto-declaração - UERJ, UENF, UNEB, UFAL, UFBA,UEL, UEMG e Unimontes adotam tal procedimento sem averiguação posterior. As outras universidades adotam algum tipo de averiguação fenotípica, através de fotos que são avaliadas por comissões (UNB, UEMS), ou diretamente através de entrevistas com estas comissões (UNIFESP, UFPR). (Santos, 2005, p.14/15)
\end{abstract}

A UnB estabelece como recurso a fotografia e institui um Comitê Avaliativo, formado por professores, estudantes e coordenação, para decidir se o candidato encontra-se, ou não, dentro dos critérios necessários, o que

\footnotetext{
${ }^{32}$ Na UERJ - a autodeclaração; na UNEB -.... e na UnB fotografia e comitê de avaliação.
} 
significaria, no caso das cotas raciais, que o candidato deveria ser considerado pertencente à "raça negra" para então ter a possibilidade de concorrer via reserva de vagas por recorte racial.

A UERJ, à seu turno, estipulou como critério a autodeclaração. De acordo com Santos, "ambos os procedimentos quando inaugurados, foram alvos de severas críticas" (2005). Comenta ainda que a mídia, à época do vestibular de 2003, lançou críticas ferrenhas, tendo como principal "mote propagandista" as supostas ocorrências de fraudes - "candidatos socialmente reconhecidos como brancos dentro do padrão de relações raciais brasileiros se declarando pardos ou pretos para disputar as vagas reservadas aos negros" (Santos, 2005, p.14/15)

O uso de fotografias, também da UnB, foi criticado, especialmente na eminência de situações paradoxais como a que envolveu irmãos consangüíneos, enquadrados em raças distintas em função da variação da cor da pele.

(...) diversos argumentos foram mobilizados vorazmente contra o uso de fotos e da criação de comissões para definição de beneficiários para reserva de vagas para negros: a idéia de que se estava criando um tribunal racial, a idéia de que se estava privando o direito de autodenominação, autofiliação e a liberdade individual de definir os pertencimentos - o que remete a dimensão dos códigos culturais associados à idéia de raça enquanto fato mediador e regulador das relações sociais, presente nas interações entre os membros da sociedade. (Santos, 2005, p.15)

Batista (2007) fazendo uma retrospectiva histórica do "conceito de raça", nas acepções conferidas pelos discursos científicos e na apropriação do termo em dadas sociedades, explica que, em princípio, privilegiou-se uma perspectiva biológica para estabelecer os parâmetros que o definiriam. Partindo deste pressuposto, teorias racistas defendiam a manutenção da "pureza" das raças, a perpetuação de umas e a extinção de outras. Foi também o critério racial numa orientação "biologicista" que respaldou o estabelecimento de classificação das raças segundo julgamento e valores de inferioridade ou de superioridade. (p.17)

No caso brasileiro, a apropriação deste termo - raça - assume novos formatos, dificultando ainda mais a luta anti-racista. A perspectiva biológica carrega uma dimensão simbólica que ganha significados rígidos e discriminatórios no plano social. É como explica o trecho a seguir:

A existência da noção de raça biológica e a evidência da raça simbólica, ou seja, da raça socialmente percebida e interpretada. Quaisquer que sejam as variações de sentido do termo raça, a desconstrução científica da raça biológica não fez desaparecerem as percepções comuns fundadas na aparência física, e em primeiro lugar na cor da pele. Culturalmente codificadas essas percepções conduzem o homem comum a classificar os indivíduos que encontra segundo suas características visíveis e não de acordo com o conhecimento genético. Esse 
hiato entre raça biológica e a caracterização social fundada na aparência física constitui um problema e um desafio para o anti-racismo. (D'ADESKY, 2001, p.01, in: Batista, 2007, p.18)

O sentido empreendido pelo movimento negro brasileiro a respeito do conceito de raça é apresentado por Gomes (2004). Vejamos de que forma:

Quando o movimento negro e pesquisadores das relações raciais trabalham com o conceito de raça, eles o fazem a partir da re-significação desse conceito. Trabalha-se com raça como uma construção social histórica e política. Reconhece-se que, do ponto de vista biológico, somos iguais, porém, no contexto da cultura, da política e nas relações sociais, a raça não pode ser desconsiderada: ela tem sua operacionalidade na cultura e funciona como fator gerador de desigualdades sociais. (p.54)

Há quem discorde da prerrogativa de Gomes (2004). São as mesmas opiniões que acreditam no paraíso racial de que falam vários autores. É preciso analisar as divergências geradas pelo tema, não tomando por base, exclusivamente, estas posições, mas, também, as dificuldades enfrentadas no estabelecimento dos critérios de definição de raça, se considerada a miscigenação do país.

O argumento da miscigenação, utilizado por muitos, embasa as críticas à política de cotas raciais, quando responsabiliza estas ações pelo acirramento do racismo e pela divisão da sociedade brasileira em raças. Ali Kamel, jornalista e funcionário da rede Globo de televisão é um dos que o utilizam.

Grande crítico da implementação do sistema no país, Kamel, mencionado na parte introdutória deste capítulo, no livro: "Não somos racistas: uma reação aos que querem nos transformar numa nação bicolor" mostra-se surpreso com a afirmação de que o Brasil seria de fato um país racista.

\footnotetext{
Mergulhado no trabalho jornalístico diário, quando me dei conta do fenômeno levei um susto. Mais uma vez a prova de que os grandes estragos começam assim: no início, não se dá atenção, acreditando-se que as convicções em contrário são tão grandes e arraigadas que o mal não progredirá. Quando acordamos, leva-se o susto. Eu levei. E, imagino, muitos brasileiros devem também ter se assustado: quer dizer então que somos um povo racista? Minha reação instintiva foi me rebelar contra isso. (p.18)
}

As considerações de Batista (2007) caminham na direção oposta das palavras do jornalista. Batista (2007) acredita que, ainda hoje, prevalece uma "dimensão especificamente racial na desigualdade social brasileira", mantendo essa ideologia viva tanto quanto "seu poder de sedução" (p.21).

A pesquisadora salienta, no que se refere ao racismo à brasileira, a organização geográfico-espacial da cidade do Rio de Janeiro e a lógica 
discriminatória que atravessa as relações dos sujeitos citadinos fluminenses. Apesar de referir-se no seu texto à consideração de Costa Pinto sobre as relações desiguais na cidade do Rio de Janeiro, na época em que a cidade era Distrito Federal, logo, referentes a outro momento histórico, suas colocações se fazem pertinentes, dada sua atualidade.

\begin{abstract}
No Rio de Janeiro - Distrito Federal à época - Costa Pinto (1952:116) apresenta a questão da segregação espacial, apontando a existência de locais destinados ao grupo étnico inferiorizado pelo grupo dominante". Esta discriminação espacial é facilmente praticada quando são levados em conta os fatores sociais, isto é, aos pobres, cuja maioria é formada por negros, são vedados alguns espaços territoriais da cidade. $O$ autor assinala a existência de atitudes e estereótipos raciais que levam a uma discrepância entre a atitude real e a opinião confessada no tocante à relação racial brasileira. Tem em vista a diferença entre o dito e 0 manifesto: discursa-se sobre a existência de preconceito de cor, mas, contraditoriamente, se expressa em diferentes ocasiões da vida social". (Batista, 2007: p.25)
\end{abstract}

Gonçalves \& Gonçalves e Silva (2006) entendem o tema do racismo no Brasil como um grande paradoxo, uma vez que institui relação assimétrica entre diferentes ao mesmo tempo em que a própria diferença é motivo de exaltação. Esta contradição faz do Brasil um país miscigenado, plural, ao mesmo tempo em que desigual nas condições e relações entre os sujeitos.

As divergências não param por aí. Os debates acalorados incluíram variadas instâncias da sociedade, mas contaram, sobretudo, com embates entre os discursos científicos. Verifica-se ao longo do trajeto das experiências aqui relatas posicionamentos por parte de pesquisadores de variadas áreas do conhecimento, a exemplo da educação, do direito e da biologia.

Com a composição de uma comissão responsável por determinar os que estarão, ou não, aptos a concorrerem via cotas raciais na UnB, sendo parte constitutiva deste Comitê Avaliativo os cientistas sociais - antropólogos mais especificamente -, o debate convoca seus interlocutores a refletirem epistemológica e eticamente sobre o tema. As divergências e os conflitos ficam latentes e se refletem nos artigos e textos publicados na área. É, pois, partindo das dissonâncias - e não das convergências - que se configuram terrenos férteis para transformações e avanços à caminho da almejada justiça social. 


\title{
3.3.7 "Os olhos e filtros cognitivos da sociedade"? O híbrido ciência- política: A antropologia e o caso da UnB
}

\begin{abstract}
A Comissão da UnB foi composta de uma estudante e três representantes do movimento negro, além de um sociólogo e de um antropólogo. Na perspectiva da Comissão como "olhos e filtros da sociedade", poderíamos imaginar que a estudante e as pessoas ligadas ao movimento negro se constituiriam nos "efetivos" representantes da sociedade, ou seja, aqueles cujos sentidos mimetizariam as percepções sociais quanto à raça e à discriminação. Já a posição do antropólogo e do sociólogo, na categoria de especialistas, seria a de monitorar e balizar o processo de classificação, observando se este estaria em consonância com o que seria esperado a partir das evidências geradas pelas ciências sociais em sua longa tradição de estudos sobre raça e relações raciais no Brasil. (Maio \& Santos, 2005, p.196/197)
\end{abstract}

“Tribunal das raças": Essa é a expressão usada por Maio \& Santos (2005), antropólogos da Universidade de Brasília e autores do artigo: "Política de cotas raciais, os "olhos da sociedade" e os usos da antropologia: o caso do vestibular da Universidade de Brasília (UNB)". Os autores propõem uma reflexão sobre as apropriações dos discursos científicos como ferramentas políticas usadas na dinâmica de implementação da política de reserva de vagas de recorte racial, mais propriamente no que diz respeito aos critérios que definirão os estudantes aptos a serem contemplados pela medida.

As considerações de Maio \& Santos (2005), críticas quanto à participação dos antropólogos e sociólogos no Comitê Avaliativo - este que chamaram de "tribunal das raças"-, encaminham uma discussão mais ampla sobre a articulação entre política e ciência e os limites ético-políticos desta hibridização na efetivação de políticas sociais, sobretudo pertinentes à temática racial no Brasil.

O debate, extremamente complexo, coloca os cientistas sociais numa arena de embates epistemológicos, sobretudo éticos. Em que pese as contradições e tensões, o fato é que, essas discussões exprimem a diversidade de temáticas que a política faz trazer à tona na medida de sua concretização nas variadas instituições, uma das razões mais significativas - acredito - da importância desta proposta no ensino superior no Brasil.

Maio \& Santos (2005) relatam a experiência da UnB, no início da concretização da política, enfatizando a atuação do comitê avaliativo, tendo como parte integrante os especialistas em antropologia e sociologia, entendendo que a atuação da antropologia prestava-se a uma espécie de "peritagem racial", na medida em que emprestava técnicas concernentes à prática antropológica, fazendo uso de critérios objetivos, em função de uma "anátomo-psicologia racial". (p.184) 
As especificidades a serem seguidas não eram muito claras, mas os indivíduos fotografados deveriam ser confirmados ou não como "negros" a partir de características físicas como cor da pele, textura do cabelo e formato do nariz. As fotos mostravam os indivíduos na mesma posição, segurando um número de identificação. Para aqueles familiarizados com a história da antropologia e da medicina, a descrição acima pode fazer lembrar práticas pretéritas, comuns entre o final do século XIX e o início do século XX. (...) Coube à comissão, designada pelas instâncias superiores da UnB e da qual participavam inclusive professores universitários, determinar quem eram os elegíveis, ou seja, os "negros" que poderiam concorrer às vagas alocadas no sistema de cotas raciais. (p.183)

Neste contexto, os autores mencionam a atuação da Associação Brasileira de Antropologia (ABA) que, segundo eles, posicionou-se publicamente avaliando os procedimentos adotados no processo seletivo da UnB, via sistema de cotas raciais de forma autoritária - os autores usam a expressão "autoritarismo vigente" - e chama a atenção para o rótulo de "tribunal das raças" que recai sobre a UnB, fazendo referência ao modo como se formata o vestibular desta instituição com o advento da política de cotas de cunho racial.

O termo "olhos e filtros cognitivos da sociedade" que, conforme explicam Maio \& Santos (2005) baseiam-se na metáfora feita por Moura (Dione Moura), designaria a tarefa conferida à comissão propriamente dita de servir como tais olhos e filtros, função esta questionada pelos autores sob o julgo de que:

(...) nela estariam encapsulados os sentidos de uma coletividade ampla. Seriam as sensibilidades de um cidadão abstrato, mas representativo da sociedade nacional,que no seu dia-a-dia das interações sociais se defronta com outros que pode vir a discriminar com base em um dado conjunto de atributos raciais. (p.196)

Os usos da ciência antropológica como um conjunto de técnicas objetivas com o fim de estabelecer parâmetros identitários bem delimitados são temas também postos em cheque no texto destes autores que recordam a prática da antropologia nas pericias em processos judiciais, desde tempos anteriores de luta por terras quilombolas quando, através da ciência, buscava-se estabelecer os critérios de definição da identidade indígena.

(...) residem na definição e na percepção quanto às identidades um dos pontos de maior tensão entre antropólogos e juízes (ou antropologia e direito, para nos referirmos aos campos disciplinares). Se para os antropólogos as identidades podem estar em constante construção e remodelação, a expectativa dos juízes é quanto a formatações discretas e precisas. (...) preocupa sobremaneira Oliveira que, diante do contexto jurídico ou administrativo de uma situação de perícia, o antropólogo passe a agir como um 'classificador de identidades'. Para além disso, pelo lugar simbólico (e prático) que ocupa devido ao status de perito, a percepção do antropólogo quanto à identidade do sujeito da pesquisa passa a assumir 'ares de verdade'. (Maio \& Santos, 2005, p.200) 
Este debate não se restringe ao campo da antropologia, tampouco da sociologia. Entra no diálogo também a Comissão de Relações Étnicas e Raciais da Associação Brasileira de Antropologia (Crer-ABA) que entende, segundo Maio e Santos (2005), que "a pretensa objetividade dos mecanismos adotados pela UnB constitui, de fato, um constrangimento ao direito individual, notadamente ao da livre auto-identificação" (p.202), além de pesquisadores do campo da genética.

O artigo dos geneticistas Sergio Pena e Maria Catira Bortoloni, de titulo: "Pode a genética definir quem deve se beneficiar das cotas universitárias e demais ações afirmativas?", é mencionado no artigo de Maio \& Santos (2005, p.203) e discute, a partir da perspectiva da ciência biológica, o conceito de raça e as apropriações na sociedade brasileira no contexto do debate sobre políticas de ação afirmativa nas universidades. Vejamos o ponto de vista dos autores:

Tendo em vista a nova capacidade de se quantificar objetivamente, por meio de estudos genômicos, o grau de ancestralidade africana de cada indivíduo, pode a genética definir quem deve se beneficiar das cotas universitárias e demais ações afirmativas? Prima facie poderia parecer que sim, mas a nossa resposta é um enfático NÃO. Vejamos o porquê. Acreditamos que a genética moderna pode oferecer subsídios para as decisões políticas e que o perfil genético da população brasileira certamente deve ser levado em conta em decisões políticas. Por outro lado, a genética não pode arrogar-se um papel prescritivo explícito.(...) a informação genética sobre a estrutura da população brasileira deve ser considerada apenas como um subsídio para o processo de tomada de decisões. Não compete à genética fazer prescrições sociais. A definição sobre quem deve se beneficiar das cotas universitárias e das ações afirmativas no Brasil deverá ser resolvida na esfera política, levando em conta a história do país, o sofrimento de seus vários segmentos e análises de custo e benefício. (Pena \& Bortolini, 2004)

Retomando os embates no campo da antropologia, uma das vozes conclamadas é a de José Jorge de Carvalho - uns dos idealizadores da proposta da política de recorte racial na UnB, em parceria com Rita Segato. O pesquisador, assumidamente "pesquisador-militante", critica a separação entre academia e política no artigo de título: "Usos e Abusos da Antropologia em um Contexto de Tensão Racial: O Caso das Cotas para Negros na UnB", e publiciza a discussão "intramuros acadêmicos" que coloca em análise os usos da ciência para fins políticos e os limites éticos de tais apropriações.

Entro neste debate na condição de autor, junto com Rita Segato, do texto da proposta de cotas para negros e índios aprovada na UnB em 2003. Não escondo que $\mathrm{o}$ assunto toca-me diretamente e justamente por isso decidi tentar contribuir para uma ampliação do contexto em que surgiram os fatos mencionados por Maio e Santos e aprofundar as discussões sobre as vinculações (negativas e positivas) da nossa rede de antropólogos com a luta contra o racismo, dentro do qual concebo o esforço das cotas para negros nas universidades brasileiras. (p.01) 
Sobre a relação entre política e academia, o autor posiciona-se da seguinte maneira:

\begin{abstract}
Meu ponto de partida é de que não há nenhum acadêmico que se possa dizer neutro nessa discussão. No limite, todos os comentadores convidados deverão em algum momento se posicionar a favor ou contra a implementação de cotas cada uma das suas universidades. Essa discussão, portanto, que fraseamos de acadêmica", é uma outra forma de expressar posições políticas e éticas, sobretudo no que se refere à manutenção ou transformação das desigualdades e discriminações raciais no nosso meio universitário. (p.01)
\end{abstract}

Carvalho (2005) discute no artigo a repercussão tomada no caso da instituição de cotas para negros, com uso do recurso fotográfico e da comissão avaliativa, situando politicamente o contexto de implementação da proposta, tendo em vista, sobretudo, o percurso histórico de lutas internas à instituição. Salienta o pesquisador que "a crítica às fotos no vestibular toma a implantação das cotas na UnB pelo final e acredito que não compreenderemos bem o tal 'uso da antropologia' se não tivermos um quadro mínimo do processo de luta desenvolvido no interior da universidade." (p.03)

Carvalho (2005) justifica a iniciativa de constituição de uma proposta de reserva de vagas para negros na UnB, em 1999, pela ocorrência de certo "conflito racial ocorrido no Departamento de Antropologia da UnB" que ficou mais popularmente conhecido como 'Caso Ari' ". Esta denominação teria referência com um estudante de nome Arivaldo Lima Alves, tendo sido ele o pioneiro entre os estudantes negros a ingressar no Doutorado, "após 20 anos de existência do programa" (p.03) Carvalho explica o seguinte:

\begin{abstract}
Logo no primeiro semestre do curso foi reprovado em uma matéria obrigatória em circunstâncias inaceitáveis e a reprovação colocou-o na iminência de perder imediatamente o curso de doutorado. Arivaldo Alves lutou mais de dois anos por uma revisão justa de sua nota. E após um processo de extremo desgaste (...) conseguiu levar o seu caso até o Cepe da UnB, que reconheceu a injustiça cometida e forçou o Departamento de Antropologia a mudar a sua nota e aprovála na disciplina, o que the permitiu permanecer no programa e terminar o doutorado ${ }^{33} \cdot(p .03)$
\end{abstract}

O professor e um dos idealizadores da proposta de cotas raciais na UnB explica que a ideia do projeto nesta universidade veio, naquele momento, motivada pela angustia diante da situação dos estudantes e da reação dos

\footnotetext{
33 Segundo Carvalho, "a professora Rita Segato era coordenadora do Departamento de PósGraduação e foi demitida sumariamente do cargo ao posicionar-se ao lado de Ari” e o próprio professor, na época orientador, sofreu "hostilidade por defende-lo diante da maioria esmagadora dos colegas" (p.03)
} 
demais colegas professores, à época, tendo por premissa a seguinte: "se é tão difícil manter um único aluno negro na UnB, vamos propor um sistema de cotas, para que pelo menos alguns negros permaneçam." (Carvalho, 2005). Partindo desta iniciativa, a proposta toma rumos mais amplos, envolvendo tanto pesquisadores negros quanto brancos, deflagrando, então, um debate no âmbito da esfera pública de modo mais abrangente.

José de Carvalho avalia como simplista o modo como foi relatado o processo de implementação da proposta de reserva de vagas para negros na UnB, pelos autores Maio \& Santos (2005), especialmente quando os mesmos comenta Carvalho - propõem-se a refletir sobre a relação da ciência antropológica na "dinâmica dos processos contemporâneos" (p.02) Carvalho (2005) frisa a importância de desvincular o Departamento de Antropologia da UnB da autoria da proposta, assumindo para si, em parceria com Rita Segato, a autoria do projeto, tendo em vista as divergências de pontos de vista entre pesquisadores/antropólogos, tanto no "caso Ari" quanto mais à diante, em relação à política de cotas para negros.

Outros aspectos, tratados no artigo de Carvalho, replicam as palavras de Maio \& Santos (2005). Sintetizam-se alguns deles nas seguintes proposições:

(1) Não há neutralidade nos discursos proferidos pelo presidente da $A B A$, de forma que suas posições precisam ser situadas não no bojo de reflexões acadêmicas "em nome da ciência antropológica", mas atravessados por posicionamentos políticos condizentes com as posições ocupadas por seus integrantes, no interior de uma "rede disciplinar fechadíssima, homogeneizante (...)" (p.) Afirma que: "É preciso saber o papel que essas pessoas jogaram e ainda jogam na dinâmica das relações raciais no interior da nossa rede de antropólogos para interpretar por que disseram o que disseram (...) sobre as fotos/cotas." (p.)

(2) Definir se a ciência antropológica deve ou não atuar na delimitação dos critérios para estabelecer quais estudantes serão ou não contemplados pelas políticas de cotas raciais seria o mesmo, segundo acredita este autor, que entender a sociedade como cindida, situando extramuros da universidade os grupos étnicos, de gênero, raciais, entre outros e no interior dele os acadêmicos que sobre eles proferirão seus conhecimentos e com base nestes, tomarão decisões. Entende Carvalho, neste sentido que,

As cotas incidem sobre nosso universo, onde mantemos nossos privilégios de brancos, e o que está em questão é decidir se vamos permanecer controlando o 
acesso a 99\% dos recursos de que dispõem as nossas instituições acadêmicas. (Carvalho, 2005, p.06)

O pesquisador chama a atenção para a importante participação de um grupo de atores sociais da Universidade de Brasília - EnegreSer - que impulsionou em grande medida a legitimação da política de cotas nesta universidade. Cita, ainda, outro incidente, além do "Caso Ari", que aponta a possível ocorrência de atos discriminação por parte dos seguranças da universidade sobre estudantes negros do curso de antropologia, numa festa ocorrida no espaço da instituição, no ano de 2001. Diante deste incidente, um grupo de estudantes se organizou politicamente e, dentre outras bandeiras, posicionou-se favorável às cotas raciais, exercendo importante participação na consolidação da proposta, relata o pesquisador.

As palavras conclusivas de Carvalho (2005) no artigo direcionam-se explicitamente aos autores Maio \& Santos e, trazem um esboço do panorama de discussões envolvendo acadêmicos do campo das ciências sociais, sobretudo envolvendo os critérios usados para definição de "raça". No caso da UnB: a fotografia. Diz Carvalho (2005):

\begin{abstract}
Como Maio e Santos, sou contrário às fotos e minha razão por discordar delas não é 'científica', mas política: as fotos despolitizam o posicionamento do sujeito ao transferir a responsabilidade de assumir sua condição racial para a comissão. O que espero da autodeclaração é que ela se generalize especularmente, de modo a alcançar não somente os candidatos ao vestibular pelas cotas, mas também a nós, acadêmicos brancos que nunca nos assumimos como tais. (Carvalho, 2005)
\end{abstract}

Em paralelo aos acontecimentos na UnB e à exemplo das divergências no interior dos espaços "acadêmicos" em várias instituições, nas variadas regiões em que a proposta foi implementada, outros debates ocorrem.

Uma obra representativa deste momento controverso - já antes mencionada neste capítulo - em resposta aos que defendem a política de reserva de vagas, seja de recorte racial seja sócio-econômico, tem por título "Divisões Perigosas" e é organizada por Peter Fry, também antropólogo/pesquisador e professor da Universidade Federal do Rio de Janeiro.

Maio \& Santos (2005) acima citados, além de Murilo de Carvalho, Lessa, Magnoli, Zarur, Maggie, etc, escrevem artigos que questionam, em sua maioria, a política de cotas e seus critérios de consolidação.

Féres Júnior (2010) faz uma análise do livro organizado por P. Fry e seleciona os argumentos usados com maior recorrência em desfavor das 
"cotas"34. A escolha, segundo o autor, foi feita a partir dos discursos que aparecem de modo mais freqüente nos textos da obra. Abaixo, os principais argumentos:

(1) Racialização da sociedade brasileira/redefinição de uma construção social (raça); (2) Violação da igualdade legal; do universalismo legal/ discriminação invertida; (3) Imposição de um sistema de identidade Binário; (4) Intervenção estatal nas relações sociais; (5) Criação ou aumento do conflito racial/promoção da intolerância racial dos negros contra os brancos e pardos; (6) Importação de categorias raciais dos Estados Unidos; (7) Não é possível separar as pessoas com base na raça no Brasil; (8) Crise da identidade nacional brasileira; (9) Privilégio da classe média negra; (10) Exclusão do branco pobre; (11) Estigmatização e vitimização dos negros;(12) Interesses eleitorais e políticos de seus patronos: políticos e líderes de movimento sociais; (13) Cor da pele e pobreza são variáveis não relacionadas à pobreza dos pretos e dos pardos não se deve ao racismo, mas a suas posições iniciais desprivilegiadas ou à educação deficiente que eles receberam; (14) É ineficiente no combate à desigualdade;(15) Rompe com a tradição brasileira de republicanismo; (16) A ênfase nos pretos aumenta a marginalização dos pardos e outros grupos organizados/genocídio estatístico desses grupos; (17) É prejudicial para o mérito; (18) política neoliberal/um instrumento capitalista para manter o status quo e dividir as classes mais baixas; (19) diminuição da qualidade da educação;(20) racismo oculto é melhor do que formas explícitas; (21) tende a se perpetuar. (Junior, 2010, p.162)

Verifica-se que grande parte dos argumentos acima elencados já foi tratada ao longo deste texto. A discussão e as divergências são inúmeras e a cada momento novas prerrogativas e pontos de vista, os mais diversos, entram na arena de discussões. Neste sentido, este capítulo não tem por pretensão dar conta de abarcar o debate na sua totalidade. A proposta, no entanto, foi de afirmar justamente a complexidade do tema e a importância de tomá-lo de forma mais contundente, considerando não somente a política de cotas, enquanto política pública de ampliação do acesso ao ensino superior e no processo de democratização brasileiro, mas, sobretudo, no que este projeto fez visibilizar no percurso de sua experiência nos diferentes contextos de implementação.

Com a vez, a experiência específica da Universidade do Estado do Rio de Janeiro nas vozes e lentes do pesquisador: A história contada pelas paredes.

\footnotetext{
${ }^{34}$ Fonte GEMAA (Grupo de estudos multidisciplinares da ação afirmativa). Argumentos extraídos de um quadro, contido no texto de Júnior, 2010, p.162. Para melhor compreensão do estudo realizado, ver referência.
} 


\title{
4.Metá-hódos em hódos-metá? No registro das peredes que guiam
}

\begin{abstract}
Em um sistema acêntrico, como conceber a direção metodológica? A metodologia, quando se impõe como palavra de ordem, define-se por regras previamente estabelecidas. Daí o sentido tradicional de metodologia que está impresso na própria etimologia da palavra: metá-hódos. Com essa direção, a pesquisa é definida como um caminho (hódos) predeterminado pelas metas dadas de partida. Por sua vez, a cartografia propõe uma reversão metodológica: transformar o metáhódos em hódos-metá. Essa reversão consiste numa aposta na experimentação do pensamento - um método não para ser aplicado, mas para ser experimentado e assumido como atitude. (Passos \& Barros in: Passos, Kastrup \& Escóssia, 2010, p.10)
\end{abstract}

As primeiras incursões no campo de pesquisa têm como nortes algumas questões:

(1) Como a política de reserva de vagas é manejada no processo de sua implementação na UERJ? (2) O que o sistema faz mover no cotidiano da universidade? (3) O que a política de reserva de vagas na UERJ, enquanto dispositivo de uma rede de agenciamentos mais ampla, faz produzir? (4) Como se dá o processo dos fluxos cotidianos na universidade produzidos a partir do sistema de reserva de vagas? (5) Que questões e temáticas a experiência da política de reserva de vagas faz suscitar e que podem ser referências para as experiências nas demais instituições públicas brasileiras?

Inicia-se o semestre. A intenção era de acompanhar o período letivo. Sendo assim, o primeiro dia de aula marca o início do processo.

O trajeto, aqui, não é tomado numa perspectiva linear, como uma sucessão de acontecimentos. Pretende-se, sobretudo, priorizar o acompanhamento dos processos. Mais intensidades e fluxos, que etapas. É como diz Barros e Kastrup (2010): "Sempre que o cartógrafo entra em campo há processos em curso". (p.56).

As autoras analisam duas acepções distintas do termo processos: Processamento e processualidades. Se o primeiro termo faz referência "à concepção de conhecimento pautada na teoria da informação", o que remete a uma prática de "coleta e análise de informações", o segundo, na contramão do primeiro, indica: "investigação de processos de produção de subjetividades" (p.58). Neste sentido, explicam Barros e Kastrup (2010) que:

O cartógrafo se encontra sempre na situação paradoxal de começar pelo meio, entre pulsações. Isso acontece não apenas porque o momento presente carrega 
uma história anterior, mas também porque o território presente é portador de uma espessura processual. (p. 58)

Diferentemente do método cientifico moderno - afirmam as autoras - que aloca etapas de pesquisa numa série bem definida e numa linha de sucessões, descritos separadamente, uma das especificidades da cartografia consiste justamente em considerar os passos que se sucedem sem separação tão demarcada. Analogamente ao "ato de caminhar, onde um passo segue o outro num movimento contínuo, cada momento da pesquisa traz consigo o anterior e se prolonga nos momentos seguintes". (p.59). Tomando como paradigma a cartografia, conhecer o campo de investigação consistia no objetivo inicial.

\subsection{As primeiras coordenadas}

O "pesquisador" chega à UERJ. Entra pelo lado que desemboca na entrada do metrô. Percorre um longo corredor por onde circulam professores, alunos, funcionários, visitantes, "passantes". Este corredor se localiza ao lado de uma arena cultural onde shows, festas, peças de teatro e outros eventos ocorrem. É neste momento que as recordações de antigas lembranças vêm á tona.

As antigas lembranças vêm do tempo de estudante de graduação em psicologia. Fez parte da nossa história, minha e de meus colegas, a programação cultural da UERJ para além dos limites das salas de aula, dentre eventos culturais, debates, outros. Ao lado da "Concha Acústica"- como a Lona cultural é chamada - localiza-se o "Teatro Odílio Costa Filho". O cenário também me remetia a recordações, sobretudo, do dia da minha formatura ${ }^{35}$.

Entrar no contexto de pesquisa, neste caso, significava revisitar, estranhar o familiar e reconhecer no novo, antigas lembranças. Dois momentos no retorno à UERJ me convocaram a este híbrido novo/velho olhar: meu ingresso como exaluna-professora da universidade e, no momento desta pesquisa, como exaluna-professora-pesquisadora. $\mathrm{O}$ uso das diferentes funções acopladas numa expressão pretende enfatizar justamente a hibridização destas posições. Os papéis estão imbricados. Não formam um conjunto de elementos separados, tampouco um bloco monolítico, mas se estabelecem numa relação dialética,

\footnotetext{
${ }^{35}$ A experiência do pesquisador se mistura com sua própria relação com o campo de tal forma que referir-se a um sujeito entrando num espaço como absoluto estrangeiro seria equivocado. Neste caso, daqui por diante a escrita privilegiará a primeira pessoa do singular.
} 
construindo, sob a forma de rede de agenciamentos, a subjetividade da pesquisadora, neste caso, a minha própria.

Alvarez e Passos (2010) entendem que:

Conhecer não é tão somente representar o objeto ou processar informações acerca do mundo supostamente já constituído, mas pressupõe implicar-se com o mundo, comprometer-se com sua produção. Neste sentido, o conhecimento ou, mais especificamente, o trabalho da pesquisa se faz pelo engajamento daquele que conhece no mundo a ser conhecido. (p.131)

É desta maneira que adentro o velho-campus-novo da UERJ: com muito de familiar - a caminhada evoca, a todo tempo, lembranças - e com muito de surpreendente diante de tantas mudanças.

Duas premissas, entre várias, se destacam no ato de investigar segundo a perspectiva cartográfica: estar afetivamente engajado - afeto aqui é entendido como implicação - e estar receptivamente disponível - compreende-se por disponibilidade, "estar aberto a", permitir-se ser guiado e surpreendido pelo campo. (p.138). Entende-se que: "Cartografar é sempre compor com o território existencial, engajando-se nele." (p.135)

Um cartaz enorme situado no início do corredor, bem em frente à entrada que liga o metrô ao prédio, chama a atenção. É em direção a este projeto que as primeiras

pistas apontam.

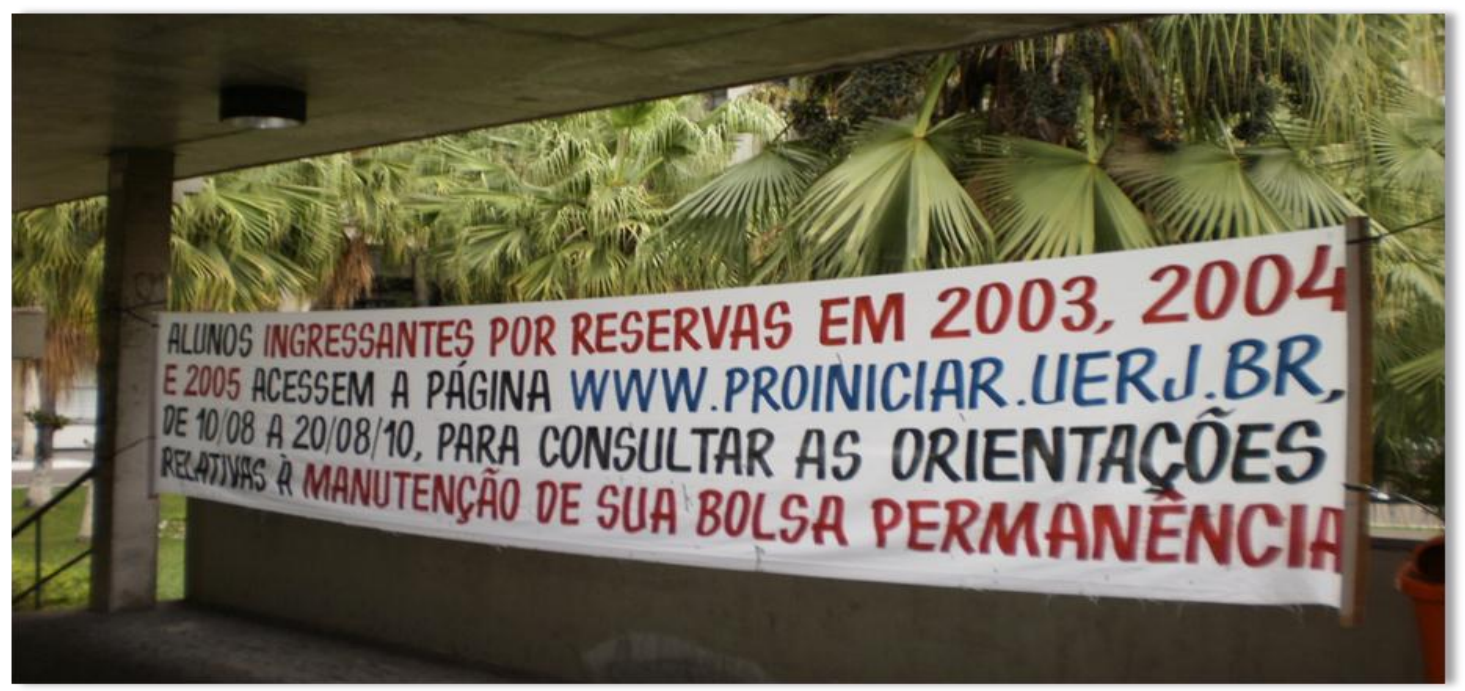

Foto 1 - Cartaz do PROINICIAR 


\subsection{Etapa preliminar - pesquisa-piloto}

Em busca das primeiras informações, chego ao Proiniciar ${ }^{36}$. Na entrada, um vidro com cartazes de cunho informativo: "Pedidos de dectarações das atividades" e os prazos de entrega para os estudantes.

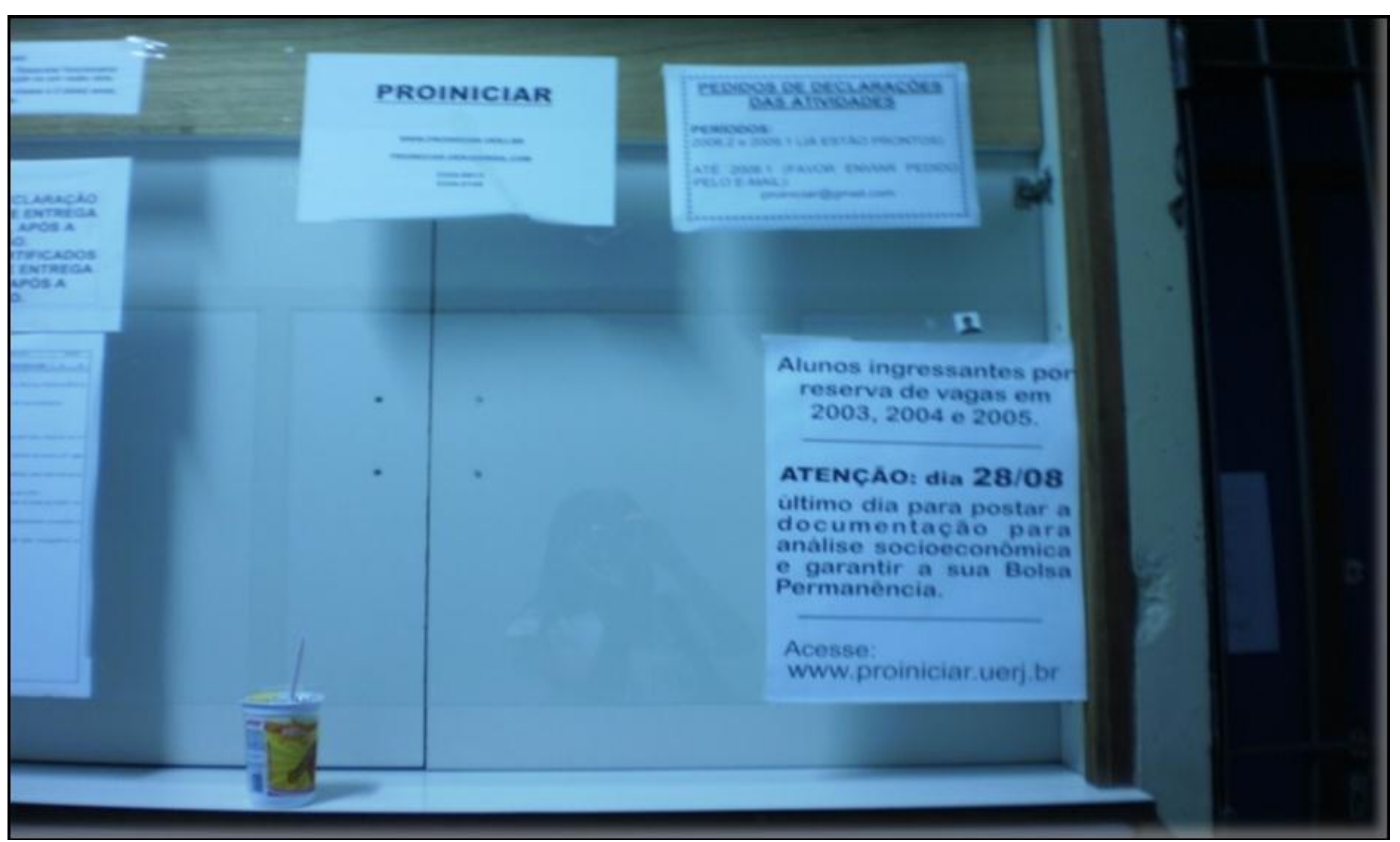

Foto 2 - PROINICIAR

\footnotetext{
${ }^{36}$ Trata-se de um programa responsável pela política de permanência voltada para os estudantes ingressantes pelo sistema de reserva de vagas/cotistas na UERJ.
} 
Feito o contato com os profissionais que fazem parte do projeto, estes logo se prontificam a me receber. Agendamos uma data para entrevista com uma das integrantes do projeto: uma entrevista-piloto. E assim ocorreu.

A proposta da entrevista-piloto era a de buscar informações sobre o modo de funcionamento do Proiniciar, na sua criação e impasses enfrentados. Os responsáveis pela organização e funcionamento do projeto forneceram documentos e alguns dados e, em uma conversa informal, explicaram-me algumas das estratégias da política de permanência e suas diretrizes.

Após análise do material obtido na entrevista-piloto, alguns aspectos fornecem pistas da experiência da política de reserva de vagas na UERJ, sob a perspectiva institucional.

As questões tratadas na entrevista/conversa circunscreviam quatro temáticas centrais: (1) O Proiniciar e as parcerias institucionais; (2) o Proiniciar na relação com os estudantes ingressos pelo sistema de reserva de vagas e como mediadores da relação entre estes próprios estudantes; (3) A relação entre estudantes ingressantes pelas "cotas" com os demais estudantes. (4) A política de permanência e os recursos materiais: entraves e polêmicas ${ }^{37}$.

A investigação-piloto, neste caso, foi fundamental. Dentre as questões citadas, a relação do Proiniciar com os estudantes, ingressos ou não pelo sistema de cotas, merece destaque, além da participação do Coletivo de Estudantes Negros da UERJ/ Denegrir que surge também como direção investigativa. Nas reuniões de recepção aos novos alunos "cotistas", a presença do grupo parece ser marcante. É o que sinalizam os primeiros dados de pesquisa.

\footnotetext{
${ }^{37}$ Serão deixadas de lado, por ora, as questões que surgem nesta primeira entrevista. Os temas serão retomados no capítulo 4 , revisitados possivelmente nas próximas etapas da pesquisa e postos em diálogo com perspectivas teóricas de pensadores. Neste momento cabe, principalmente, apresentar o percurso metodológico e as reflexões que surgem deste processo.
} 


\subsection{Em busca das Ferramentas Metodológicas}

\subsubsection{Re-conhecendo o território}

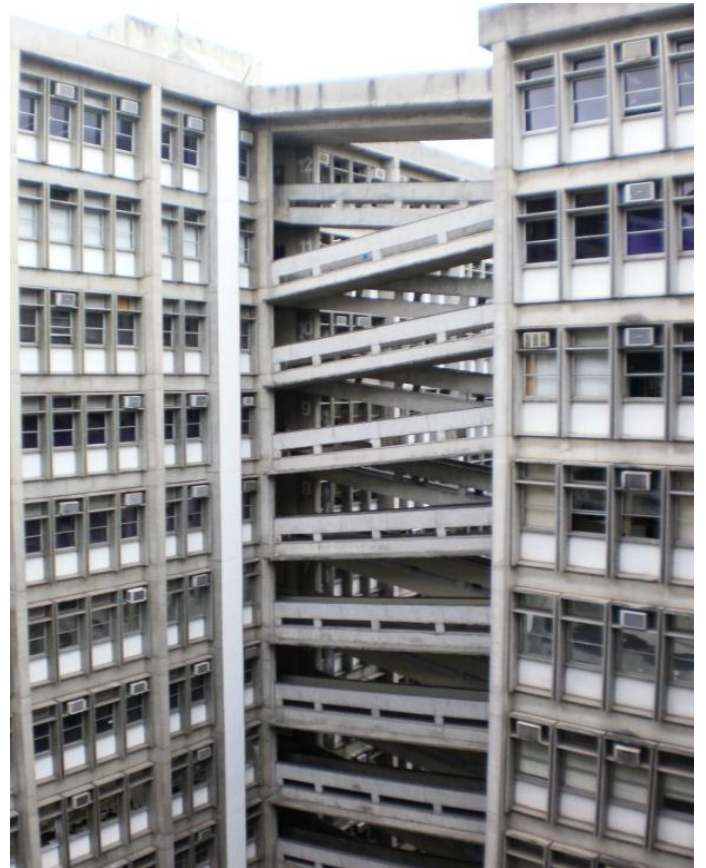

Foto 3 - UERJ

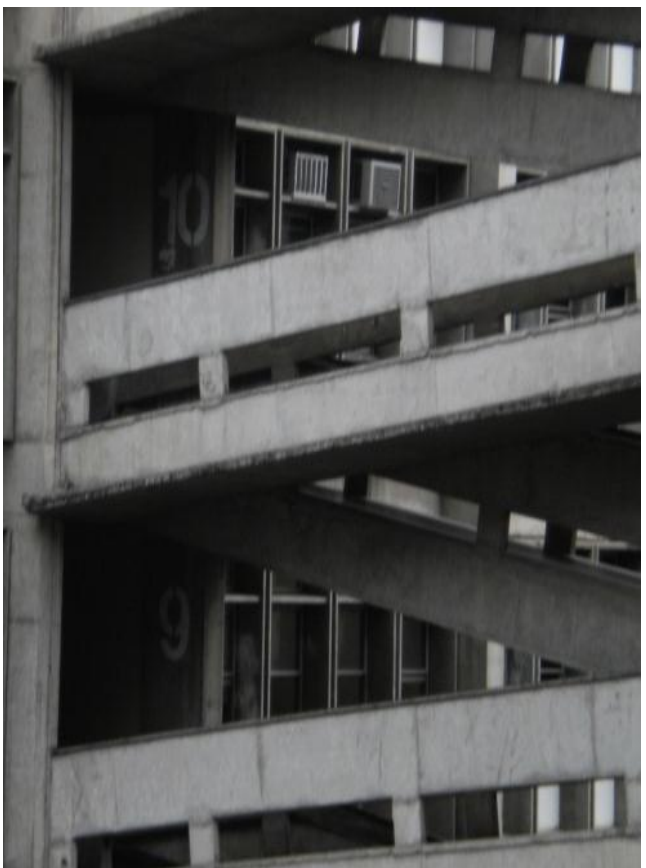

Foto 4 - UERJ

Caminhar implica em passar. Para isso é preciso fazer escolhas. São muitas as possibilidades. O ponto final do percurso - aonde se chega e não o fim - importa tanto quanto a passagem. O trajeto todo - o início, o percurso, o ponto de chegada - são determinantes. Salientar alguns destes pontos da linha de passagem implica em decisões que envolvem o pesquisador que se permite ser guiado pelo campo, não desconsiderando seus interesses e suas impressões.

Participam também os "atores" que passam, porque se deslocam pelos espaços da UERJ, com seus interesses e expectativas. São todos "passantes", que se movem diferentes e que afetam e são afetados durante o percurso. Portanto, é de todos a autoria da caminhada que aqui se pretende relatar, construir e mostrar.

Alvarez e Passos (2010), conceituando o método cartógrafo como "habitação de um território existencial", confrontam um "pesquisar sobre", que situa sujeito e objeto em posições dicotômicas, com um "pesquisar com", tendo 
por princípio acompanhar as singularidades mais do que as generalidades. Conferem, ainda, privilégio a um agenciamento entre os eventos e a um "rastrear dos ritmos", mais que a um "controle dos processos". A pesquisa, sob esta égide, teria por definição:

(...) uma forma de cuidado quando se entende que a prática da investigação não pode ser determinada só pelo interesse do pesquisador, devendo considerar também o protagonismo do objeto. A investigação é o cuidado ou cultivo de um território existencial no qual pesquisador e pesquisado se encontram. (p.144).

$\mathrm{Na}$ assertiva anterior: "é de todos a autoria da caminhada que aqui se pretende relatar, construir e mostrar", cabe incluir, na definição da palavra "todos", o "território". É num certo espaço construído e praticado, com histórias, apropriações, pré-concepções e subversões, em que é feita a caminhada. Logo, as escolhas recaem também nas possibilidades descortinadas pelo território, extensivas aos demais elementos a ele interconectados.

A concepção de território privilegiará, aqui, certa dimensão dentre as muitas possíveis. A primeira delas toma por base a cartografia como perspectiva metodológica. Segundo Alvarez \& Passos (2010), Deleuze e Guattari aproximam o conceito aos sentidos e modos de expressão, em lugar de "aspectos utilitários e funcionais" (p.132). Nestes termos, dá-se ênfase aos ritmos e à expressividade, como no trecho a seguir:

O território é uma assinatura expressiva que faz emergir ritmos como qualidades próprias que, não sendo indicações de uma identidade, garantem a formação de certo domínio". (...) Os sujeitos, os objetos e seus comportamentos deixam de ser o foco da pesquisa, cedendo lugar aos "personagens rítmicos" e às "paisagens melódicas (...) esses personagens e suas paisagens não são considerados como polos opostos e dicotômicos, mas compõem mutuamente, numa circularidade ou coemergência. (p.133/134)

No rastro das interconecções territorializantes, sobressaltemos, pois, "os personagens ritmos" e as "paisagens melódicas".

A UERJ - Campus Maracanã - Rio de Janeiro é o campo desta pesquisa. Descrever o espaço da UERJ pelos nomes oficiais não garante fácil localização e circulação para os que o desconhecem, a menos que um destes, recémchegado, perdido, tome como única estratégia o mapa oficial e o siga literalmente. No caso de precisar pedir informação aos "anfitriões", bem provável ouvir indicações como: "Você procura o subsolo da capela? Fica bem ao lado da espinha da baleia". Ou "você procura a livraria? Fica bem em frente ao queijo". 
É bem verdade que os pontos de referência elucidativos - "queijo" e "espinha da baleia", marcam diferentes relações de espaço-tempo do pesquisador na UERJ. O primeiro - o queijo - talvez nem seja mais usado como ponto de referência, tendo em vista que assim chamávamos o monumento de cimento no formato de um queijo, na época de estudantes de graduação. Já o segundo - espinha da baleia -, aprendi recentemente com meus alunos. Certa vez minha aula foi incomodada por um barulho de música eletrônica e funk. Foi quando um dos alunos me esclareceu: "Está tendo choppada ${ }^{38}$, professora! Lá na espinha da baleia." Daí que me dou conta de que aquela instituição já não me era tão familiar. Precisaram me esclarecer que se tratava de um local ao lado do estacionamento, bem em frente à entrada do metrô, onde as festas ocorriam atualmente.

O ocorrido me remete a Certeau (2011), quando chama os antigos objetos da cidade, resistentes à restaurações, obsoletos, a "espíritos do lugar". Sendo "provenientes de passados decifráveis, são para nós o equivalente do que eram alguns deuses da antiguidade". (p.192) O queijo continuava no mesmo lugar, mas este nome remetia bem mais a um evocar de meu "espírito remanescente" do que às vivências cotidianas mais recentes.

O corredor que liga a UERJ ao metrô, lugar de maior visibilidade possível, agora ganhava ares de festas com grande infra-estrutura eletrônica e as músicas do momento. Reverberando nas palavras de Certeau (2011): "Os gestos são verdadeiros arquivos da cidade, se entendermos por "arquivos" o passado selecionado e reempregado em função de usos presentes. Refazem diariamente a paisagem urbana." (p.199/200)

Sobre a restauração da arquitetura de certo lugar - vale mais as práticas criativas destas mudanças do que os objetos em si - Certeau (2011) nos leva a pensar que: "As velhas pedras renovadas se tornam lugares de trânsito entre os fantasmas do passado e os imperativos do presente. São passagens sobre múltiplas fronteiras que separam as épocas, os grupos e as práticas”. (p.194)

Tendo em vista que conhecer o espaço implica em extrapolar as denominações oficiais, privilegiarei "dizer/mostrar" o espaço sob as diferentes perspectivas - oficiais e oficiosas -, numa mescla e, acompanhando meu trajeto. Com a intenção de convidá-los - aos leitores - a seguirem esse percurso, as devidas "legendas" - escritas com textos e/ou com imagens - serão trazidas na medida da descrição dos passos.

\footnotetext{
${ }^{38}$ Festas de recepção aos novos alunos - calouros - com chopps e musica, nas imediações da instituição.
} 


\subsubsection{Agosto de 2009...}

Início do semestre letivo. Começo a percorrer as rampas dos 12 andares da UERJ, nos blocos A, B, C, D, E, F, G e H $\mathrm{H}^{39}$.

No primeiro andar, se entramos pelo corredor que liga o metrô ao edifício Reitor João Lira, caímos de imediato no hall mais movimentado do prédio: o da entrada dos elevadores. No mesmo local encontram-se: a livraria, o "queijo", um telão onde são transmitidas palestras informativas. Há também um laboratório de informática - na minha época funcionava uma Xerox - e, logo abaixo, na lateral, a central dos seguranças. Há ainda, bem centralizado, um balcão de informações.

O entra e sai de transeuntes é intenso, sobretudo nos horários de término e início dos turnos. O turno da noite, que se inicia às 18:00h, é o de maior movimento em função do grande contingente de estudantes-trabalhadores na UERJ. De dois lados, um de frente pro outro, bem na entrada dos elevadores, pode-se observar quadros de avisos envidraçados. Embora um localize-se ao lado do outro, cada parte do quadro está restrita ao uso de um determinado grupo, entre partidos políticos (PSTU, PCB - Partido Comunista Brasileiro, MPR - Movimento Popular Revolucionário, PT - Partido dos Trabalhadores) e grupos militantes como o Denegrir, já antes citado.

\footnotetext{
39 Do primeiro ao 12 andar, o prédio João Lira, todo feito de concreto, por isso a aparência acinzentada, é dividido hermeticamente em dois lados. $O$ hall dos elevadores encontra-se no meio dos andares e serve de localização para os corredores. Assim, saindo dos elevadores à esquerda estão os blocos A, B, C e D. Do lado oposto: E, F, G e H. Há placas explicativas ao alto. As rampas, acima referidas, ligam os dois lados. Depois de muito subir e descer esses andares, ainda na época da graduação no curso de psicologia, que se situa no 10 andar, descubro felizmente que duas rampas correspondem a um lance de escada. Se quiser subir mais rapidamente, vá pelas escadas. Caso a intenção seja pelo menor esforço, as rampas são a melhor escolha.
} 


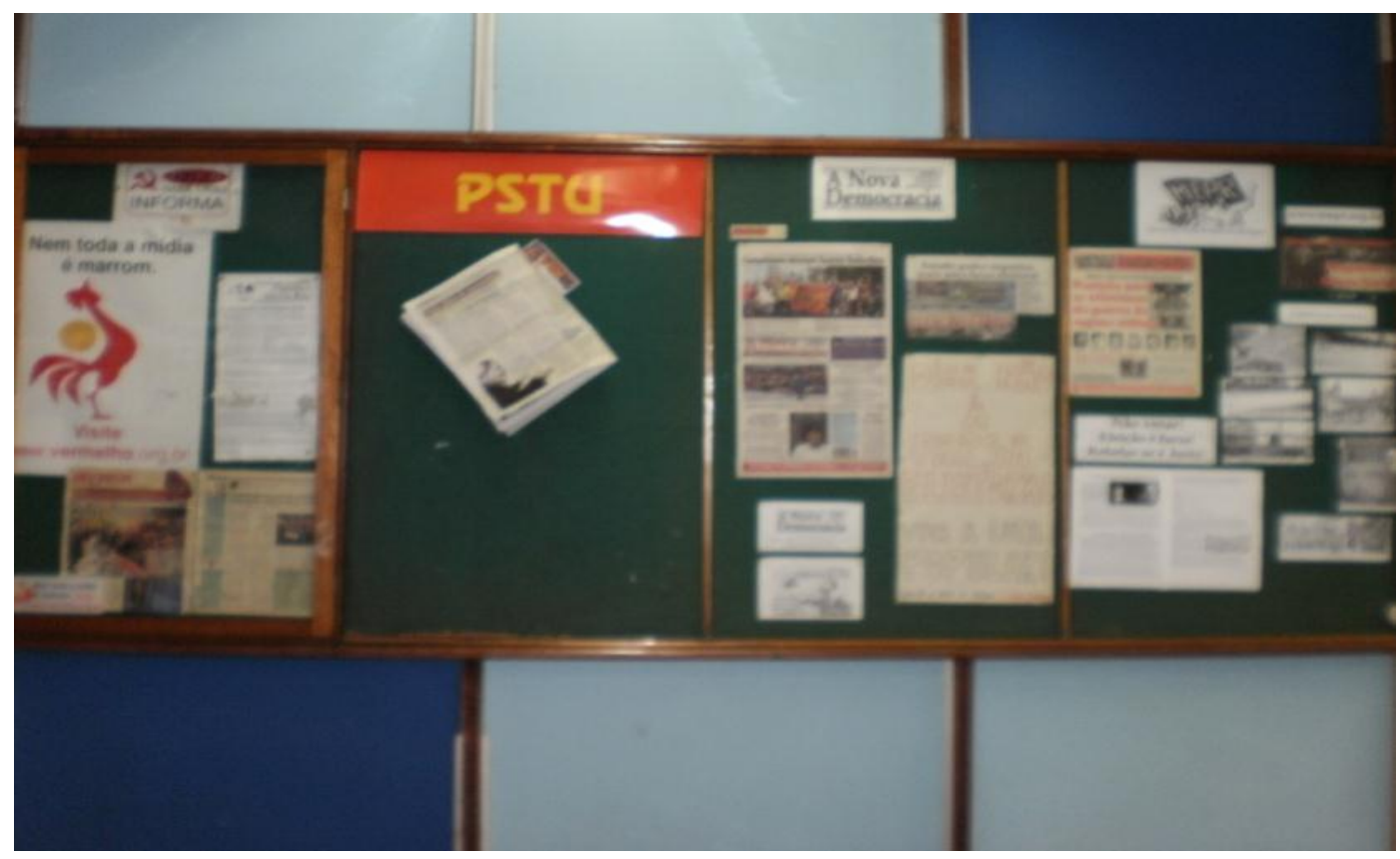

Foto 5 - Quadro de avisos/hall de entrada dos elevadores: PCB, PSTU, Nova Democracia, MEPR.

As notícias e informes dos quadros mudam a cada dia e, ao que tudo indica, trazem debates, polêmicas, reivindicações bastante atualizadas. O fluxo de materiais é intenso. O que faz parecer é que o "entra e sai" de avisos coloca à mostra, temáticas de interesse de alguns grupos politicamente ativos na UERJ. Acompanhar os cartazes, especialmente os fluxos destes materiais surge, então, como possível caminho metodológico, desta vez, menos protocolar.

Partindo desta premissa, passo a observar os demais corredores da instituição. Na frequência de duas vezes por semana, subo de elevador ao último andar do prédio e sigo descendo as rampas, acompanhando nos quadros: escritos, textos, charges, desenhos.

$\mathrm{Na}$ realidade, o que me movia, à princípio, era a busca por possíveis eventos que envolvessem a temática da reserva de vagas. Interessava-me a programação da instituição à respeito da política de cotas, ou melhor, a agenda que eu supunha que existisse à respeito, como debates, reuniões, rodas de conversa. Encontro alguns eventos pontuais, em sua maioria, informes e avisos do Proiniciar, materiais fornecidos para estudantes ingressos pelo sistema e um, ou outro, debate em períodos esparsos.

O primeiro debate registrado teve como organizador o Sindicato dos Trabalhadores da UERJ - SINTUPERJ. A discussão foi disparada por um filme: 
O Grande Desafio ${ }^{40}$. Posteriormente encontro outro evento. Desta vez, organizado por uma aluna do curso de ciências sociais, com convidados da academia para um debate sobre as cotas raciais.
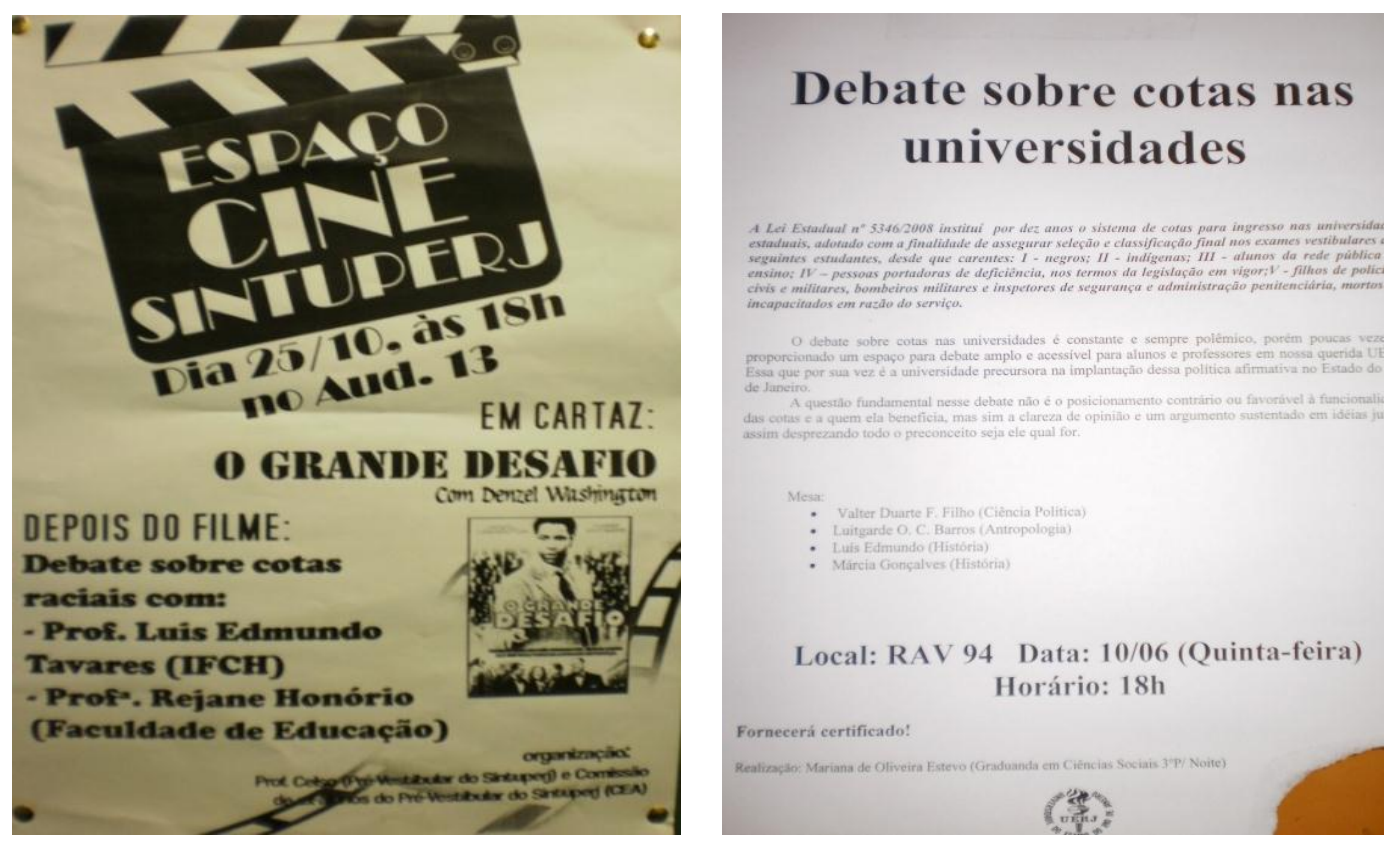

Fotos 6 e 7 - Informativos de debates sobre as cotas na UERJ

Os cartazes referem-se a debates organizados pelo Sintuperj - Sindicato dos Trabalhadores da UERJ e por uma aluna de graduação do curso de ciências sociais à época, ambos sobre o tema das cotas raciais.

Faço o registro no diário de bordo ${ }^{41}$. Após muitas andanças, acompanhando os murais e buscando nos panfletos quaisquer sinais que apontassem caminhos, percebo que, a cada semana, os murais estão diferentes, os panfletos mudam, os corredores ganham novos formatos e cores.

Nos demais andares, os quadros de avisos têm seus respectivos usuários bem definidos. Cada curso de graduação tem o seu espaço, de uso restrito dos integrantes dos Centros Acadêmicos e da instituição. Informes, festas, cursos, textos de cunho político, denúncias.

\footnotetext{
${ }^{40} \mathrm{O}$ filme traz com questão a luta pelo espaço na educação por estudantes negros marcando a discussão sobre racismo e o projeto educacional.

${ }^{41}$ Um pequeno caderno de bolso, de cor laranja, no qual deposito todas as impressões, observações, acontecimentos e tudo mais.
} 

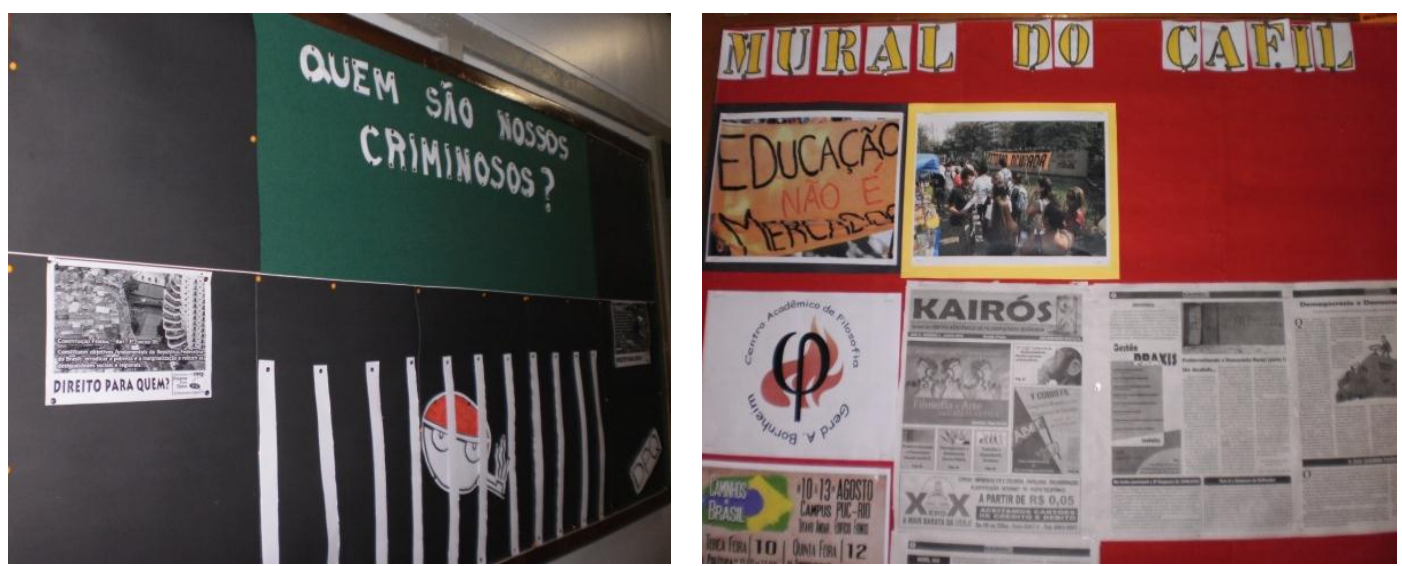

Fotos 8 e 9 - Quadros de Avisos dos CAs de Direito e de Filosofia

O tema da política de cotas aparece poucas vezes de forma explícita. Entretanto, percebo a recorrência de temas a ele tangentes e inúmeras imagens e panfletos veiculados nos corredores, sejam nos espaços oficiais, sobretudo, nos oficiosos.

Tudo leva a crer que o modo mais usual de comunicação na UERJ é por intermédio de cartazes, bilhetes, textos afixados nas paredes.

Curioso e surpreendente é notar que não somente os quadros autorizados pela instituição veiculam informações, mas também espaços não convencionais como as paredes onde se localizam bebedouros, banheiros, armários, cantinas, pilastras e, até o chão de cimento situado na subida e descida para os andares onde se localizam os cursos de graduação.
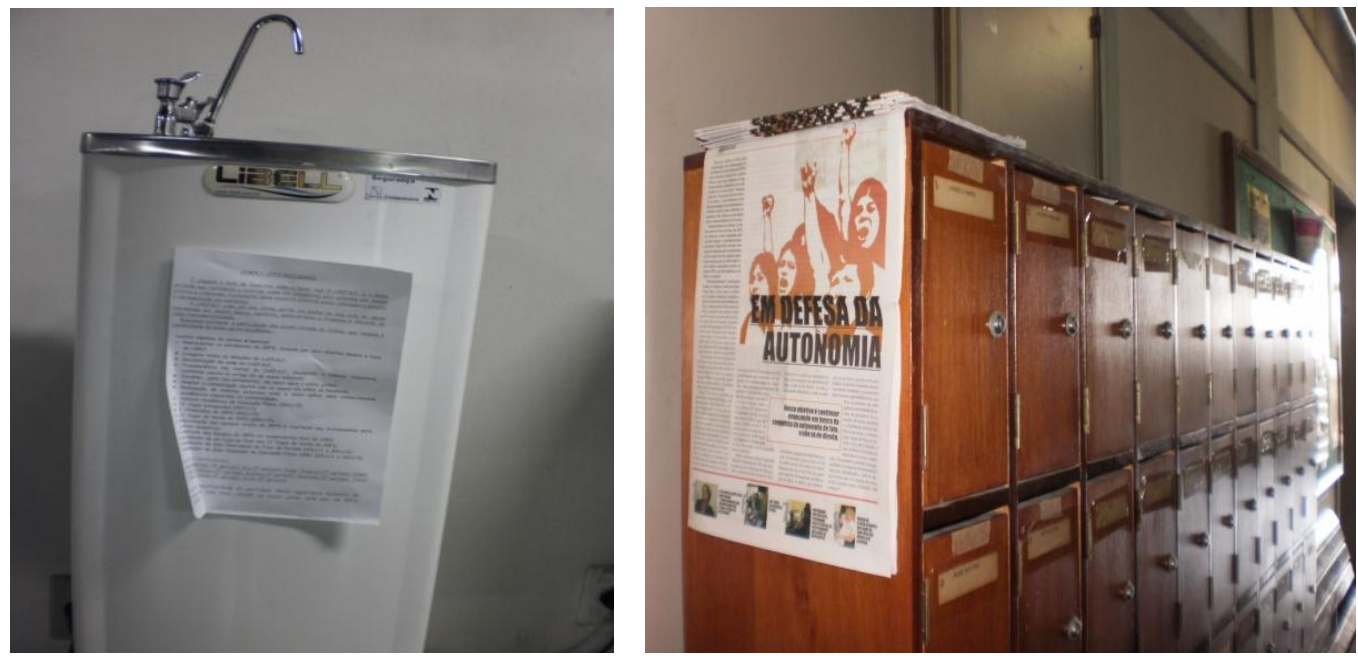

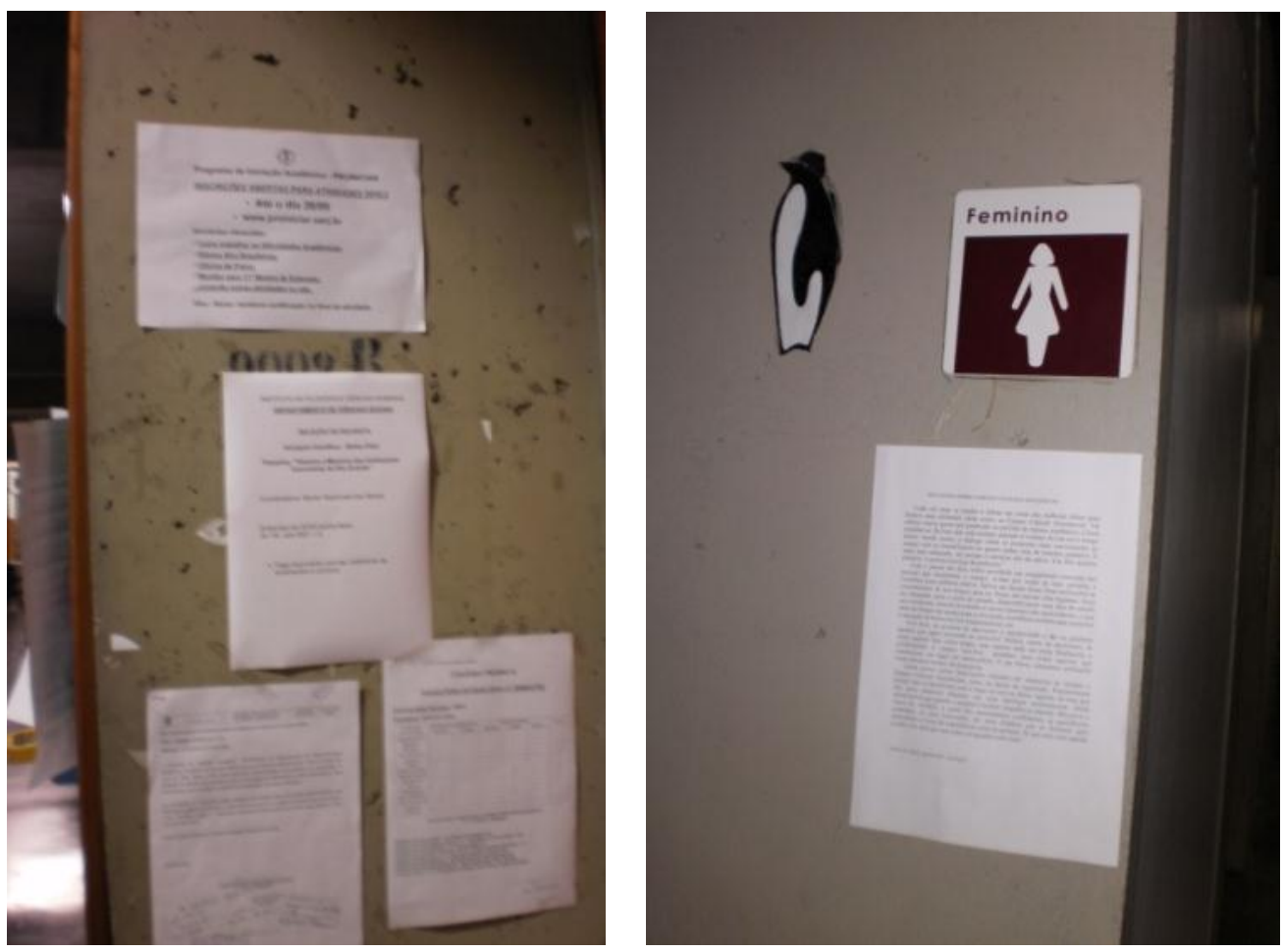

Fotos 10, 11, 12 e 13 - Locais de circulação extra-oficiais com informes

As fotos acima são ilustrativas de locais onde foram encontrados panfletos informativos e jornais. Um bebedouro, um armário localizado no corredor de um dos cursos, a parede na entrada de uma sala de aula e a entrada de um banheiro feminino. O conteúdo dos cartazes são variados: carta do centro acadêmicos aos estudantes, informes de reuniões, notas de alunos, seleção de estágios, etc.

Chama a atenção ainda o fato de que, o prédio de concreto, cinzento, ganha cores e formatos originais na medida da apropriação dos espaços pelos sujeitos, dos usos que fazem deles cotidianamente.

É neste sentido que o pesquisador inicia uma cartografia geográficoespacial, tomando, como principais recursos, suas próprias lentes, ou seja, seu campo de visão. O velho-campus-novo da UERJ se torna neste momento, para o pesquisador, mais novo que velho.

Os trajetos do pesquisador passam de distraídos a vigilantes. Qualquer escrito, rabisco feito à mão, anônimo ou de autoria bem definida, pode significar pistas. A entrada das secretarias nos seus murais, com contornos bem delimitados pela instituição, dividem os espaços com os panfletos afixados nas portas das salas e também nas paredes. As salas de aula, incluindo as portas de entrada, "se comunicam" com os alunos avisando de faltas eventuais de professores, cursos oferecidos, "choppadas", festas, peças teatrais, palavras de ordem, reivindicações e denúncias. Forma curiosa dos alunos do curso de 
engenharia de anunciarem a festa dos alunos: através de escritos no chão de cimento, no hall do
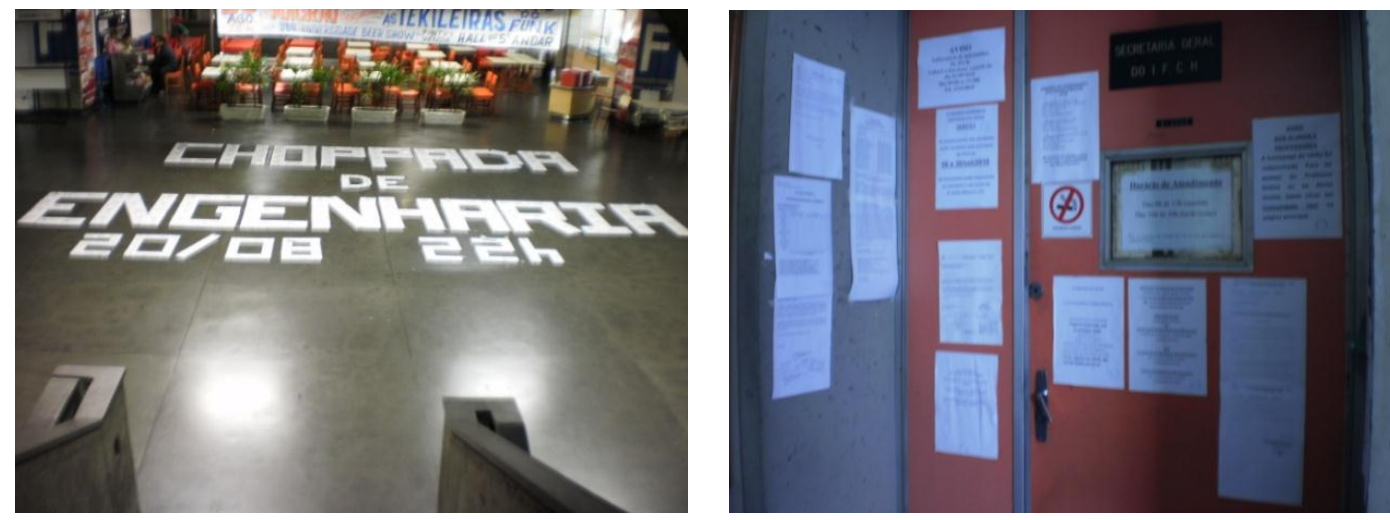

Fotos 14 e 15 - hall do $5^{\circ}$ andar e entrada de uma secretaria de curso. A primeira foto foi feita na descida da escada que chega ao $5^{\circ}$ andar. A segunda imagem é da entrada da secretaria de um curso de graduação.

Algumas das salas de aula destacam-se das demais em razão das cores, dos móveis, dos ares de "sala de casa", de escritórios, salões de eventos, jogos, etc. As mobílias, entre redes e sofás, junto às pixações, grafites, pinturas e quadros informativos, fazem das salas de aula comuns o "quartel general dos alunos", divididos pelas áreas de formação. São os CAs - Centro Acadêmicos dos Estudantes.

Os CAs localizam-se nas salas de aula, que ganham especificidades e particularidades na medida da ocupação dos estudantes de cada curso.
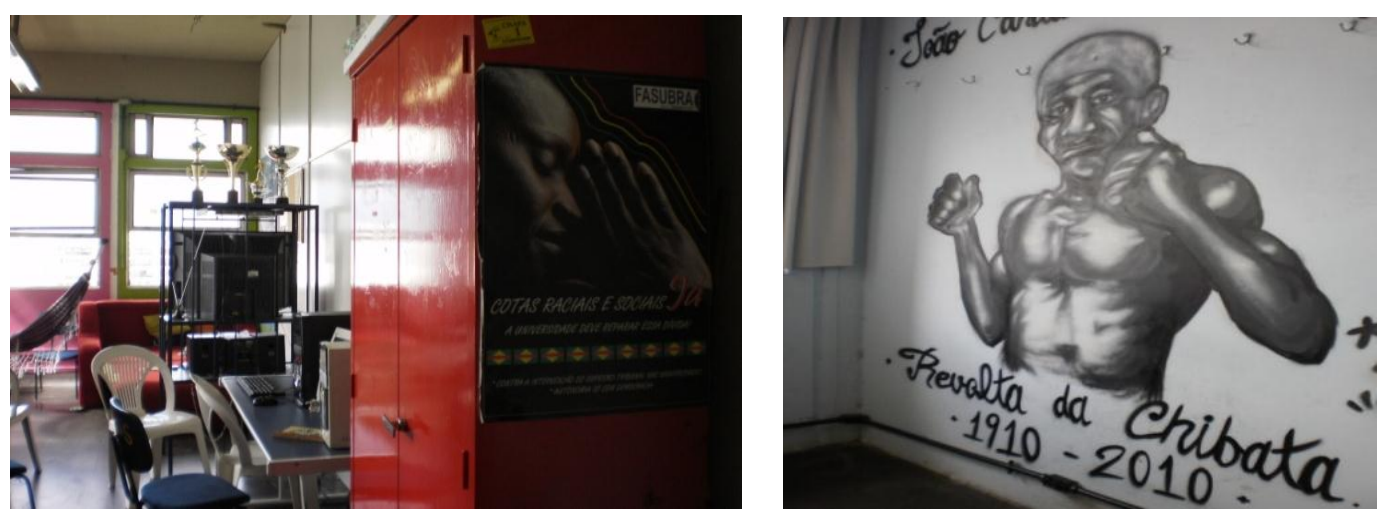

Fotos 16 e 17 - Centros Acadêmicos de ciências sociais e de história.

Algumas paredes têm desenhos, pinturas, grafites. Sofás e redes conferem um tom de descontração e informalidade a alguns desses espaços. Outros se assemelham a escritórios, mais frios, operacionais. Cada coletivo de estudantes, 
nos seus projetos políticos, apropria-se de seus "territórios" imprimindo identidades próprias aos espaços.

É como nos faz refletir Certeau (2011), acerca do capital de uma nação ou uma cidade:

Seu patrimônio não é feito dos objetos que ela criou, mas das capacidades criadoras e do estilo inventivo que articula, à maneira de uma língua falada, a prática sutil e múltipla de um vasto conjunto de coisas manipuladas e personalizadas, reempregadas e "poetizadas". Finalmente, o patrimônio são todas essas artes de fazer. (p.199)

$\mathrm{Na}$ entrada de cada um deles, as siglas indicam a quais cursos pertencem: CAEFALF, CAIME, CAENG, CAPF, CALC, CAPSI, CAFIL, CACIS, CAHIS ${ }^{42}$. As placas ou grafites, com desenhos característicos, funcionam como legendas para os "estrangeiros".
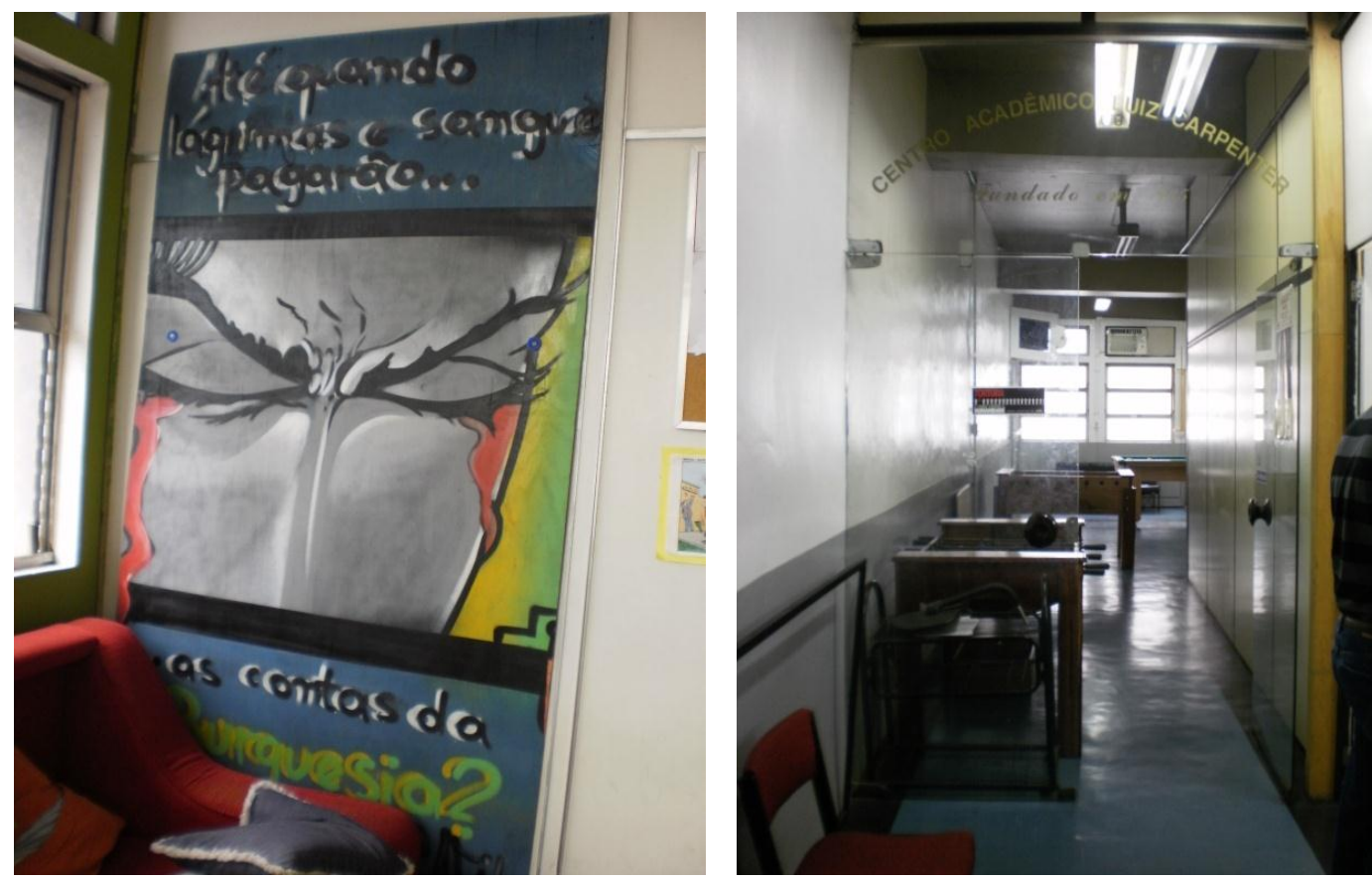

Fotos 18 e 19 - Centro Acadêmico de Ciências Sociais e Centro Acadêmico do curso de direito.

Algumas siglas são por si sós, explicativas, no que se refere aos cursos que representam, como: CAENG, CAPSI, CAFIL, Centros Acadêmicos de engenharia, psicologia, filosofia, respectivamente. Outras exigem conhecimento mais específico sobre seus referenciais, a exemplo do CAPF e do CALC, Centro Acadêmico Paulo Freire (curso de pedagogia) e Centro Acadêmico Luiz Carpenter (curso de direito), respectivamente.

\footnotetext{
${ }^{42}$ CAs de: educação física, matemática, engenharia, pedagogia, direito, psicologia, filosofia, ciências sociais e história respectivamente.
} 

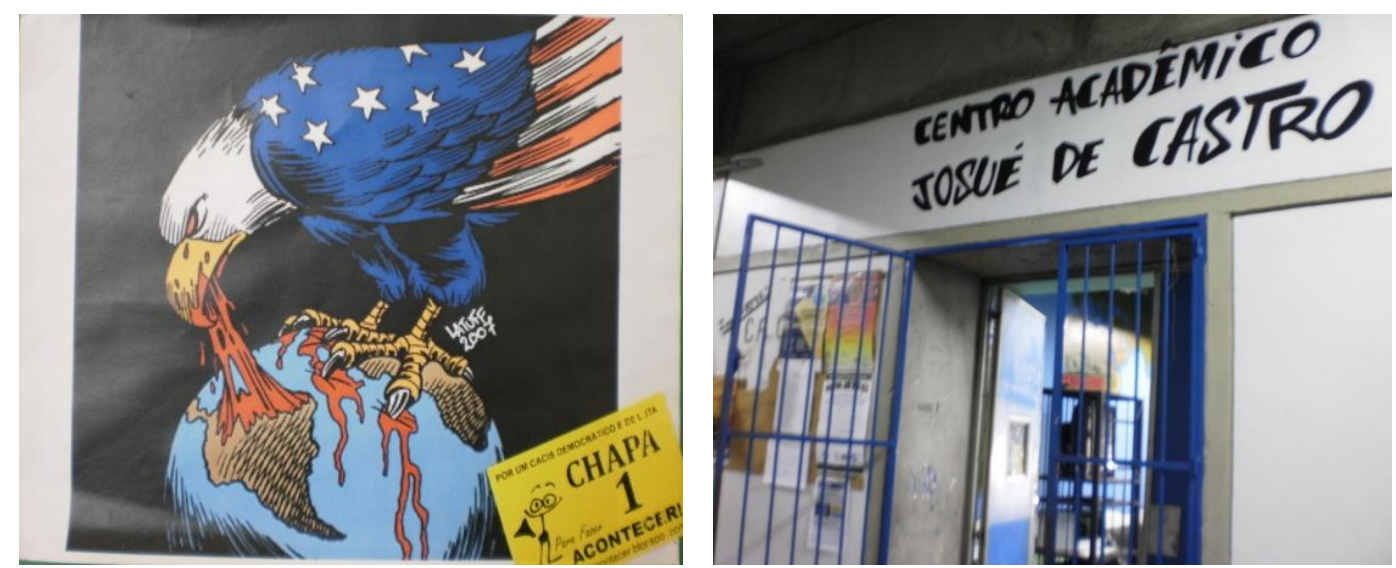

Fotos 20 e 21 - Centros Acadêmicos de Ciências Sociais e de Psicologia

Entrar numa sala de aula com sensação de "casa dos outros", com sofás, desenhos com traços identitários marcantes relativos aos grupos de estudantes dos variados cursos, faz refletir sobre estes modos de apropriação e sobre o sentido destes espaços para os estudantes, elucidadas com as palavras de Certeau (2011):

O território onde se desdobram e se repetem dia a dia os gestos elementares das 'artes de fazer' é antes de tudo o espaço doméstico, casa da gente. De tudo se faz para não retirar-se dela, porque é o lugar em que a gente se sente em paz. Entrar em casa, no lugar próprio que, por definição, não poderia ser o lugar de outrem. (p.203)

Na entrada da Xerox e nos estacionamentos, também é possível encontrar cartazes. Em todo lugar dizeres e imagens coexistem, entre as falas institucionais/oficiais, reivindicações de alunos, recados entre os próprios alunos, expressões artísticas, anúncios de vagas de apartamentos, prestadores de serviço externos à comunidade que vão desde digitadores de tese, professores de línguas, estrangeiros, agências de viagens, agência de intercâmbio de estudos em outros países, a grupos religiosos. 


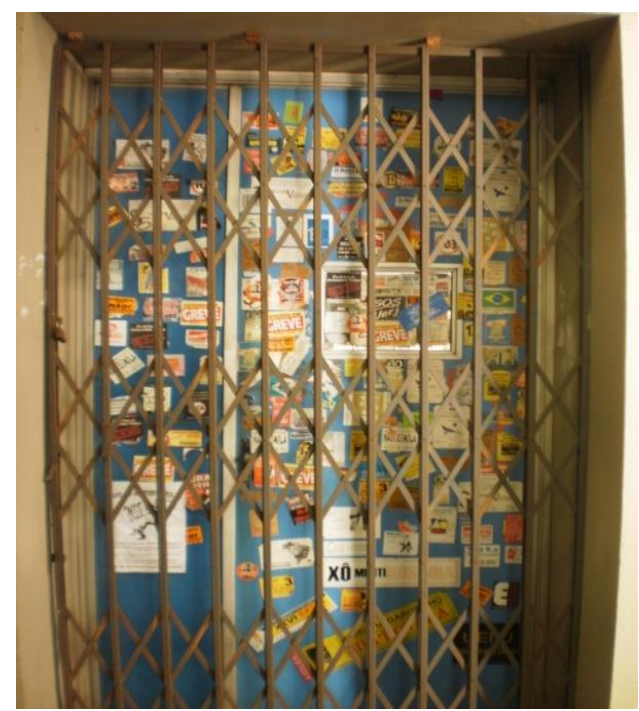

Foto 22 - Entrada do Centro Acadêmico de Serviço Social.
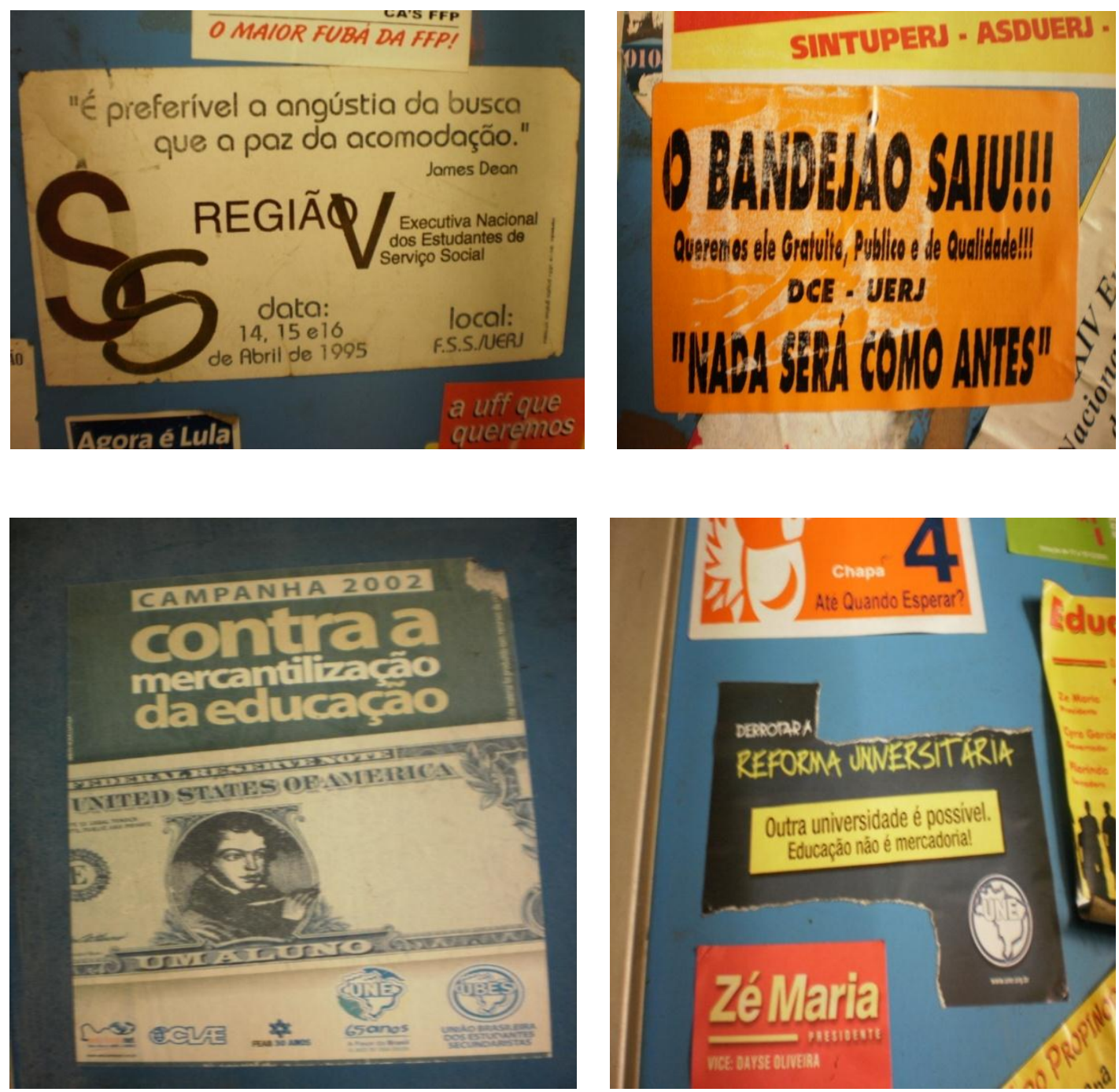

Fotos 23, 24, 25 e 26 - Adesivos colados na entrada do Centro Acadêmico de Serviço Social. 
Dentro dos banheiros, no interior das paredes privativas, debates escritos a canetas ou com rabiscos de chaves. Os temas? Política, sexualidade, variedades.

Eis o caminho que se descortina: "A UERJ fala pelas paredes". Atrás dos recados e lembretes deixados pela comunidade acadêmica interna e externa, se descortinam possibilidades de dizer/mostrar o que a implementação do sistema de cotas fez/faz deflagrar no cotidiano da instituição.

O diário de bordo já não comporta tantas anotações. Em pé, com caderno em mãos, tento apreender toda a sorte de frases e textos que me capturam, mas a ferramenta da escrita já não resolve diante da variedade de panfletos e diferentes modos de expressividade. Na medida em que relato no grupo de pesquisa o que vejo na UERJ cotidianamente, nos murais e nas paredes, sinto certa dificuldade em conseguir retratar com palavras o que sobressalta no meu campo de visão. Os debates e discussões sobre a política de reserva de vagas, nos temas a ela subjacentes, estavam expostos de maneiras peculiares nas paredes da universidade. É neste sentido que as diferentes formas de expressões passam a exigir distintos modos de registro.

Barros e Passos (2010) nos fazem refletir sobre a função do registro no processo de pesquisa cartográfica. Segundo os autores: "O trabalho da pesquisa deve ser sempre acompanhado pelo registro não só daquilo que é pesquisado quanto do processo mesmo do pesquisar". Entendem ainda que: "O registro do processo da pesquisa interessa porque inclui tanto os pesquisadores quanto os pesquisados. Neste sentido, tal registro se complementa no ato de sua restituição". (p.172)

A perspectiva cartográfica confere papel fundamental ao registro, tomandoo como dispositivo de pesquisa, para além de simples método de investigação. Um dispositivo, diferente de uma estratégia metodológica sistemática, funciona, sobretudo, como um "disparador de desdobramentos de pesquisa", conferindo aos relatos um status de "política da narratividade". Nestes termos, "o modo de dizer e o modo de registrar a experiência se expressam em um tipo de textualidade que comumente é designado como diário de campo ou diário de pesquisa." (Barros e Passos, 2010, p.173). As imagens diziam mais que palavras. De que forma poderia se dar esse registro?

A imagem feita em grafite confere uma identidade ao hall do 90 andar, onde se situam os cursos de ciências sociais (CACIS), história (CAHIS), filosofia
(CAFIL)
e
educação
física
(CAEFALF). 


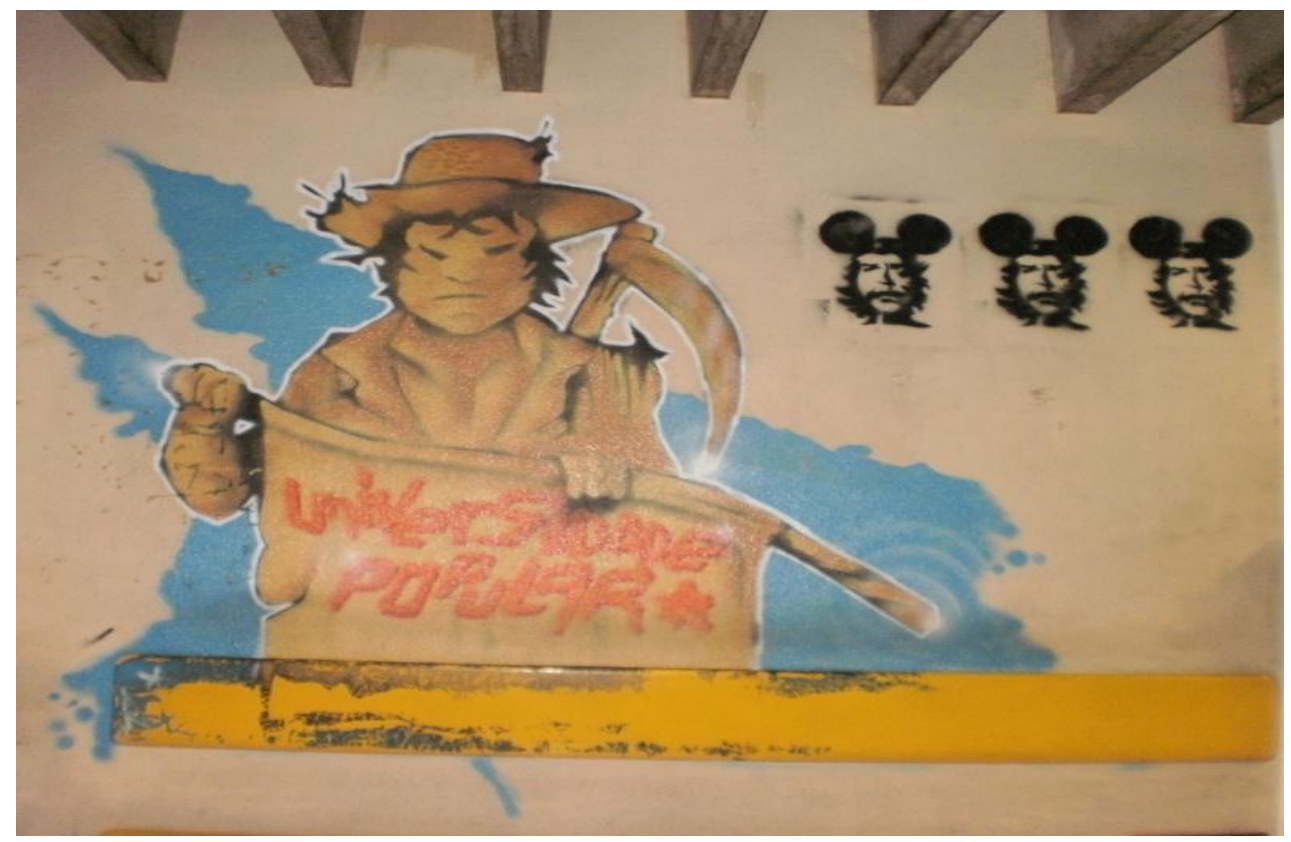

Foto 27 - parede do hall do nono andar

A imagem me remetia às discussões sobre a democratização do ensino público universitário brasileiro. Curiosa ainda a possibilidade de fazer uso do espaço desta maneira. Os que olham de fora, desavisados, veem um prédio cinzento, de aparência bucólica, apática. Por dentro, subversões da arquitetura, interferências indicam vida, acontecimentos, fluxos.

No mesmo andar - o 9 andar - duas outras mensagens ressaltam aos olhos de quem passa. Uma delas é a de uma faixa denunciando a não utilização de uma das salas de aula com recursos audio-visuais, chamada de RAV, com a autoria dos três cursos acima mencionados.

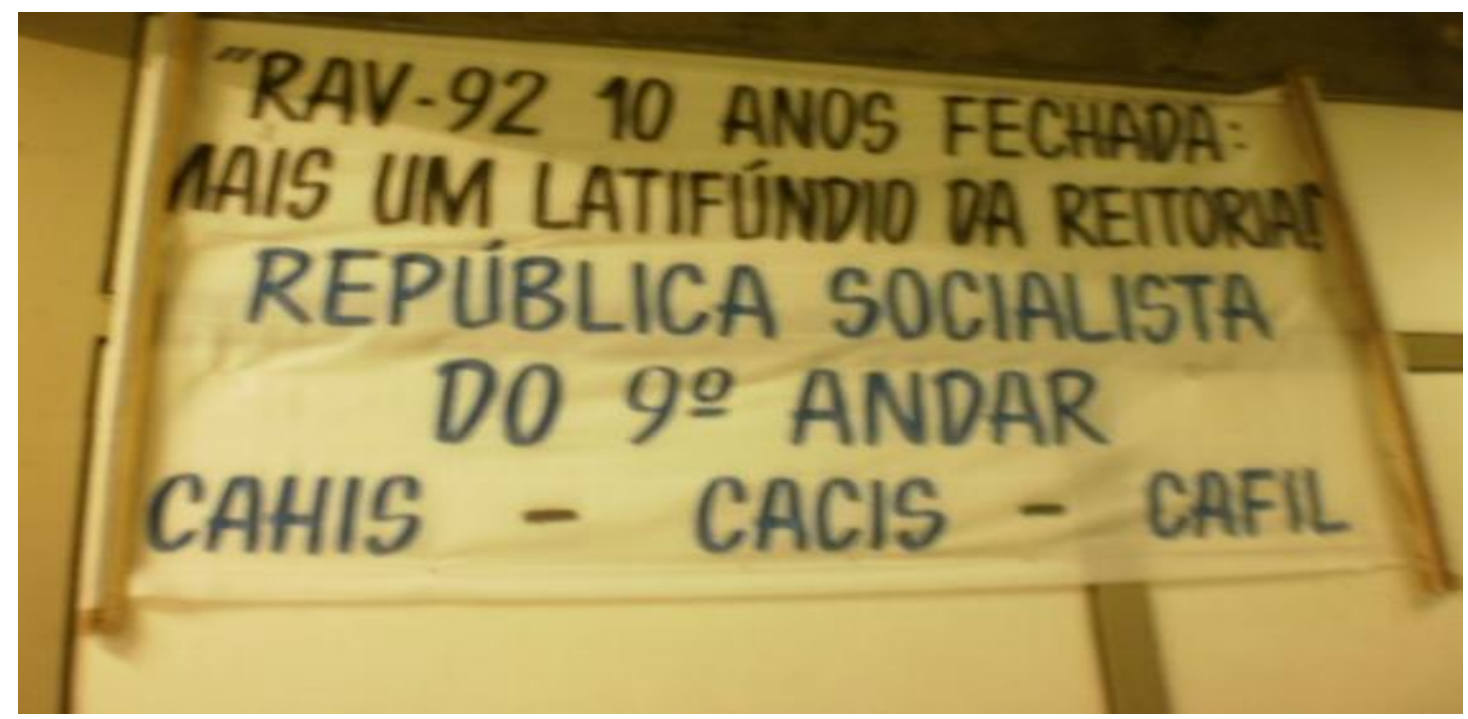

Foto 28 - Hall das salas de aula do nono andar 
No mesmo andar, outra sala trazia na sua entrada (colados à porta) cartazes, fotos, escritos representativos de lutas e propostas. O espaço "pertencia" ao grupo Denegrir ${ }^{43}$. A sala recebeu a denominação de "sala Abdias Nascimento".

Os desenhos e fotos na entrada da sala suscitavam reflexões sobre a participação dos movimentos sociais organizados, especialmente o movimento negro, nas políticas de ação afirmativa nas universidades ${ }^{44}$.

As imagens diziam mais do que ilustravam. Líderes do movimento negro e outros dividem espaço com um símbolo e um número escrito ${ }^{45}$ junto à palavra Denegrir.

\footnotetext{
${ }^{43}$ Grupo Denegrir - coletivo de estudantes negros e negras da UERJ.

"O Coletivo de Alunos Negr@s da UERJ surgiu da necessidade de discutir a questão racial ignorada no âmbito acadêmico. Foi batizado com o nome DENEGRIR, com o propósito de denunciar a discriminação e o racismo contidos na nossa sociedade, inclusive na utilização de palavras. DENEGRIR significa tornar negro e ganhou sentido de infamar, macular, manchar ou ofender.Na contramão da atual utilização do verbo, propomos a reconstrução da sua utilização com significação positiva: DENEGRIR -tornando a universidade mais negra".

Trecho extraído do site do grupo. Endereços: http://br.groups.yahoo.com/group/denegir_uerj2005 Site: http://www.denegrir.cjb.net

${ }^{44} \mathrm{~A}$ participação dos movimentos sociais organizados e do movimento negro na implementação da política de reserva de vagas no Brasil está melhor abordada nos capítulos 1 e 2 deste trabalho.

${ }^{45}$ O número refere-se ao numero da sala onde se situa a sede do movimento.
} 


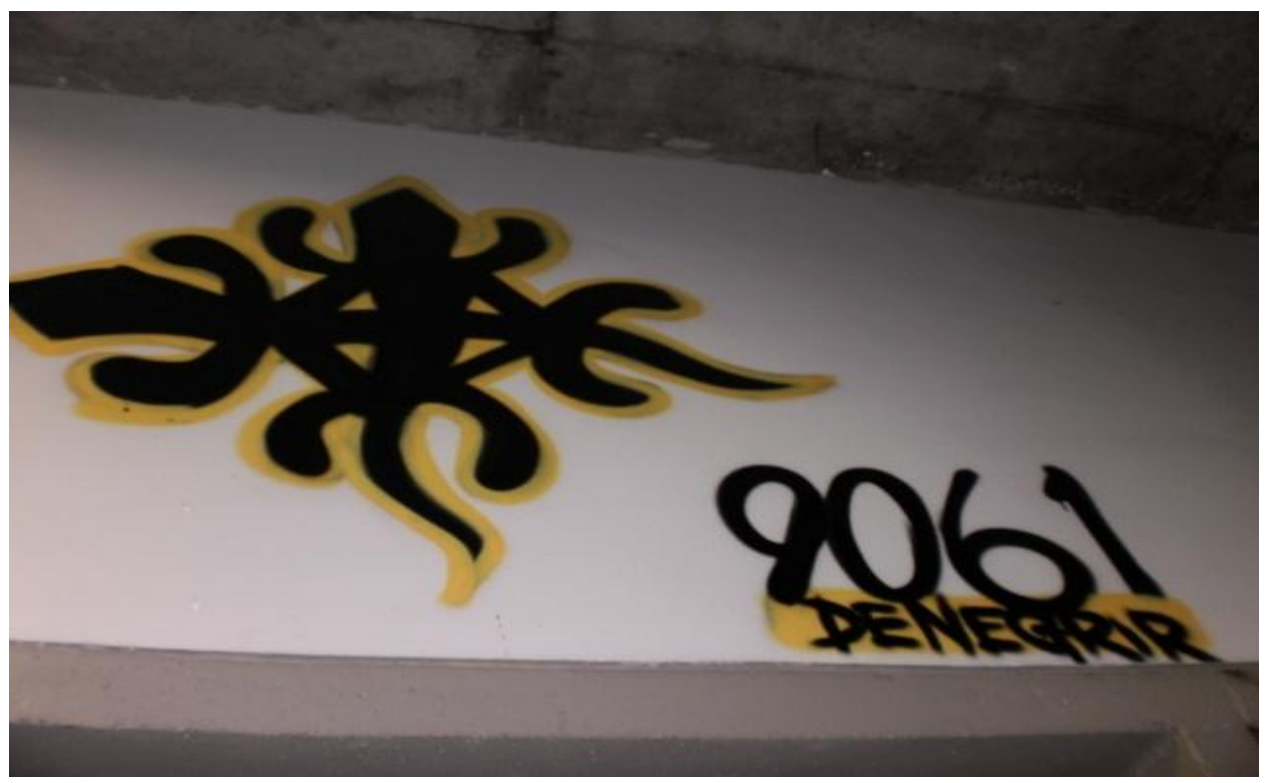

Foto 29 - Denegrir

Como registrar/apreender tanta informação no seu fluxo de acontecimentos? A cada dia os murais apareciam diferentes. Alguns dos textos eram tirados e outros tomavam lugar. Havia os que permaneciam fixos. Estes pretendiam demarcar o território. Delimitar os "proprietários" dos espaços.

Tendo em vista que a UERJ faz parte de um contexto mais amplo - a cidade urbana contemporânea -, as linhas divisórias entre comunidade interna e externa se arrefecem. A cidade adentra o campus, o campus se estende para os arredores e espaços adjacentes.

Partindo do princípio de que as paredes da UERJ funcionam como mediadoras da comunicação entre os vários atores e, mais do que isso, que o fluxo de mensagens postas nas paredes e a grande rotatividade desses dispositivos de comunicação parecem acompanhar os acontecimentos na Universidade, surge como proposta metodológica seguir os fluxos cotidianos através das 'paredes-contadoras' de histórias.

Quando Alvarez e Passos (2010) definem o método cartográfico como a prática de habitar um território ( $p .147$ ) - neste caso, um território existencial relativo a modos de vida e expressividades, ao invés de espaços meramente físicos que conjugam respostas motoras - os autores conferem ao pesquisador um papel de "aprendiz- cartógrafo". O aprendizado implica, aqui, em experiência de engajamento, "que só se dá à medida que se realiza, sem pré-condições." (p.147).

Acompanhar o fluxo de acontecimentos significaria colocar-se como mais um passante-consumidor das mensagens publicizadas. A todo momento, o 
pesquisador pela via da sensibilidade e não somente pela observação científica, circula nos espaços da UERJ como um "habitante", atento, disperso, sobretudo, focado. O foco no objeto de pesquisa direciona seu olhar. É isso que faz a distinção com outros passantes, especialmente os mais distraídos, atarefados, apressados. Mas, há que se considerar que mesmo estes, aparentemente desavisados, pausam em alguns pontos do percurso, identificados com mensagens e dizeres, na maioria a eles endereçados, mas nem sempre. Muitos, curiosos, são movidos pelos discursos, outros pelo senso estético, quando não são praticamente cooptados a percebê-los nos espaços de rotina mais improváveis: banheiros, bebedouros, Xerox das cantinas, etc. Mas da parte do pesquisador, cartógrafo, não convém dar explicações tampouco interpretações sobre o que chama a atenção dos transeuntes. Cabe seguir o rastro das intensidades, dos fluxos expressivos. Segundo Barros e Castrup (2010), é como diz Rolnik (2006):

\begin{abstract}
Entender, para o cartógrafo, não tem nada a ver com explicar e muito menos com revelar. Para ele não há nada em cima céus da transcendência -, nem embaixo brumas da essência. O que há em cima, embaixo e por todos os lados são intensidades buscando expressão". (Rolnik, 2006 in: Barros e Kastrup, 2010, p.61)

O pesquisador é também sujeito da pesquisa, uma vez que o campo de investigação é, ao mesmo tempo, seu campo de trabalho. Antes, como estudante de graduação, desta vez como professora e pesquisadora. As funções se hibridizam e também os olhares sobre o campo de modificam e se misturam. De que forma conciliar tantas posições sem perder de vista o foco de
\end{abstract} investigação?

Barros e Kastrup (2010) definem como objetivo da cartografia, "justamente desenhar a rede de forças à qual o objeto ou fenômeno em questão se encontra conectado, dando conta de suas modulações e de seu movimento permanente". Daí a importância de "se deixar levar por esse campo coletivo de forças" (p.57). Esta perspectiva soa, muitas vezes - especialmente sob o julgo dos mais empiricistas -, relativista, ausente de rigor científico e de critério. A réplica mais apropriada, frente a tais julgamentos, seria a que propõe uma metodologia cuja estratégia, com vistas a acompanhar os fluxos em lugar de representá-los, é a de uma "concentração sem focalização" (p.57), o que pressupõe que:

A ausência do controle purificador da ciência experimental não significa uma atitude de relaxamento, de "deixar rolar". A atenção mobilizada pelo cartógrafo no trabalho de campo pode ser uma via para o entendimento dessa atitude cognitiva até certo ponto paradoxal, onde há concentração sem focalização. O desafio é 
evitar que predomine a busca de informação para que então o cartógrafo possa abrir-se ao encontro. (p.57)

Desta forma, faz-se necessário retomar duas das condições primordiais da pesquisa cartográfica: disponibilidade e engajamento. Daí a impossibilidade de definir as estratégias de pesquisa antes do processo investigativo. $O$ trajeto é que, sob a égide da cartografia, definirá os passos percorridos, na medida da própria caminhada.

É desta forma que se descortina o uso de um recurso metodológico coerente com as idiossincrasias do campo: o registro fotográfico.

Benjamin (1994) analisa as possibilidades conferidas pelo surgimento da fotografia, em lugar da litografia ou das artes gráficas, na medida em que:

Pela primeira vez no processo de reprodução da imagem, a mão foi liberada das responsabilidades artísticas mais importantes, que agora cabiam unicamente ao olho. Como o olho apreende mais depressa do que a mão desenha, o processo de reprodução das imagens experimentou tal aceleração que começou a situar-se no mesmo nível que a palavra oral. (p.167)

No decorrer deste texto - em que são intercaladas imagens e escritos deixo escapar, não sem propósito, a escolha pela estratégia metodológica: a cartografia-fotográfica.

O livreto de bolso que guarda as impressões e relatos do pesquisador, sob o formato de descrições, não perde sua função; apenas passa a contar com uma nova ferramenta de registro: a câmera fotográfica digital. A UERJ se comunica de várias maneiras e agrega uma pluralidade de gêneros discursivos, entre imagens e escritos. Posto isto, torna-se necessário coadunar o método de pesquisa com as práticas cotidianas que ocorrem no contexto de investigação.

Bakhtin (2003) analisa a heterogeneidade dos gêneros do discurso vinculando o conteúdo temático, o estilo, a construção composicional, ligados ao todo do enunciado, às especificidades dos campos de comunicação nos quais os discursos são proferidos. Diz o autor que:

O emprego da língua efetua-se em forma de enunciados (orais e escritos) concretos e únicos, proferidos pelos integrantes desse ou daquele campo da atividade humana. Esses enunciados refletem as condições específicas e as finalidades de cada referido campo não só pelo seu conteúdo (temático) e pelo estilo da linguagem, ou seja, pela seleção dos recursos lexicais, fraseológicos e gramaticais da língua mas, acima de tudo, por sua construção composicional. Todos esses três elementos - o conteúdo temático, o estilo, a construção composicional - estão indissoluvelmente ligados no todo do enunciado e são igualmente determinados pela especificidade de um determinado campo da comunicação. (p.262). 


\subsection{A pesquisa propriamente dita}

\subsubsection{A linguagem fotográfica como recurso}

Quais os efeitos da política de reserva de vagas na experiência subjetiva dos sujeitos que deambulam no campus da UERJ, que se pode apreender a partir do que as suas paredes, repletas de signos e sentidos, são capazes de contar?

Precisava de um foco que direcionasse a escolha das imagens, em meio a tantas e a tamanha velocidade de circulação. Se o tema da política de reserva de vagas nem sempre era tratado de forma explícita, contando com os poucos eventos organizados pelos mais proximamente engajados com a discussão, debates acalorados envolvendo temáticas tangentes à proposta permeavam as paredes de modos variados. A escolha de sub-categorias que tangenciam o tema mais amploserviu como fio-condutor do percurso. Estes sub-temas, vale esclarecer, não foram escolhidos aleatoriamente, mas de acordo com o que as próprias paredes apontavam, tendo sido selecionadas 11 categorias, quais sejam: (1) Ação Afirmativa/cotas; (2) Democratização do ensino; (3) Democratização da Universidade; (4) Racismo; (5) Cultura-afro; (6) Divisão de classes; (7) Preconceito; (8) Diversidade na Educação; (9)Universidade popular; (10) Luta/militância Estudantil; (11) Juventude Popular.

Tendo sido delimitada a direção - registrar tudo o que fosse relativo ao tema da política de reserva de vagas, a partir das subcategorias estabelecidas o pesquisador caminha, diariamente, com a posse da máquina fotográfica digital. Importante salientar que não há qualquer familiaridade prévia do pesquisador com a técnica da fotografia. A câmera surge como um dispositivo de registro na intenção de fixar as imagens que o campo de visão do pesquisador é capaz de flagrar. No transcorrer de trânsitos cotidianos pela UERJ, a câmera assume a função do diário de bordo, depositário das anotações, observações e impressões do pesquisador, não perdendo de vista a especificidade do modo de registro possível de cada uma destas ferramentas.

Neste sentido, a princípio impera o amadorismo de um "aprendiz-defotógrafo". De tal maneira que o manejo da ferramenta torna-se um empecilho. Como focar a imagem, empreendendo a distância apropriada? Quais as possíveis formas de registro diante da variabilidade de formatos expressivos, entre textos escritos com letras miúdas e grafites e/ou pinturas que tomam uma parede toda? 
Com quase nenhuma expertise, dão-se início as primeiras relações entre o pesquisador e o aparato tecnológico. $O$ instrumento passa a fazer parte dos utensílios pessoais de uso diário carregados na bolsa. A busca pela imagem perfeita, que neste caso seria a mais clara e nítida, capaz de permitir a leitura das minúcias, no caso dos textos, ao mesmo tempo em que apreendesse seu contexto de exposição, nem sempre era possível. Na maioria das vezes, o registro tinha que ser feito com certa rapidez diante de muitos passantes à frente da imagem, especialmente nos horários de maior movimento.

A velocidade no ato da fotografar dependia da oportunidade e decorria do fluxo tanto das pessoas que por ali passavam quanto da rapidez da circulação das próprias imagens. De um dia para o outro, aquele panfleto, recado, cartaz, não estava mais lá.

Os textos escritos em letras minúsculas, expostos em grandes murais e entremeados por uma variedade de outras imagens, muitas vezes eram de difícil legibilidade. Era aí que entrava a atuação dos recursos da máquina digital: o zoom. Precisava, pois, aprender a fazer uso dos recursos, menos para fins de aprimoramento técnico, do que para alcançar a meta principal: a pesquisa. $O$ zoom seria útil para amplificar as letras. O que se pretendia era, em única instância, ter acesso ao conteúdo das imagens/textos e garantir a reprodução em outros espaços de modo a por em diálogo os interlocutores das paredes e os receptores para quem seus discursos eram destinados. De fato, a máquina digital propiciaria um uso posterior das imagens, que outros aparatos, menos tecnicamente desenvolvidos não seriam capazes de permitir. Esta constatação fez Benjamin (1994) quando analisava a perda da autenticidade diante da obra de arte, na medida em que se torna possível sua reprodução, perda esta que não faria sentido no caso da reprodução técnica. Explica que:

\begin{abstract}
Em primeiro lugar, relativamente ao original, a reprodução técnica tem mais autonomia que a reprodução manual. Ela pode, por exemplo, pela fotografia, acentuar certos aspectos do original, acessível à objetiva - ajustável e capaz de selecionar arbitrariamente o seu ângulo de observação -, mas não acessíveis ao olhar humano. Ela pode, também, graças a procedimentos como a ampliação ou a câmera lenta, fixar imagens que fogem inteiramente à ótica natural. (p.168)
\end{abstract}

Experimentando, fotografando, errando e construindo sua própria técnica, segue o pesquisador, aprendiz-de-fotógrafo, até o momento em que a máquina fotográfica assume o papel de diário de bordo. Não se tratava de uma fotografiaarte, mas de aprender uma arte de fotografar pragmaticamente, com funcionalidade. A melhor foto seria a que fosse mais nítida e a que garantisse a apreensão das informações contidas na imagem. Reproduzir quantas fotos fosse 
possível, significava aproveitar a oportunidade, a ocasião, de modo a não perder informações valiosas que, possivelmente não poderiam ser adquiridas em nenhum outro momento. Daí a apreensão de perder os registros, trabalhos de um dia todo, que nem sempre poderiam ser novamente apreendidos em novas ocasiões.

Debates, com réplicas e tréplicas, entre chapas oponentes, tensões entre estudantes e os representantes dos seus devidos cursos, tudo acontecia com a velocidade dos fluxos de idas e vindas, na passagem pela universidade.

As experiências que o pesquisador e câmera fotográfica vivenciam no processo de observação/registro, assemelham-se às andanças de um estrangeiro na terra do outro, ao mesmo tempo em que em sua própria terra.

A "pseudo-invisibilidade" era descoberta justo pela presença da própria máquina fotográfica. Em algumas situações, ela despertava a curiosidade de quem passava e suscitava imaginários e indagações; era o que parecia diante das expressões e olhares de alguns sujeitos diante da presença de alguém com uma câmera fotografando os espaços, cartazes e paredes. Mas eram poucos. O que era mais frequente era a invisibilidade frente à correria dos que entram e saem mergulhados nos seus afazeres e preocupações e na rotina acelerada dos tempos atuais.

O lugar de um estrangeiro ficava latente na medida em que precisava do convite ou da autorização de outrem para adentrar em certos espaços que tinham seus usuários e, porque não "proprietários", bem definidos. A apreensão de como conseguir entrar na sala do Denegrir para fotografar as paredes pintadas em grafites que conseguia visualizar pelas frestas da porta, poucas vezes entreaberta, marca um destes momentos.

Certeau (2011) nos inspira a refletir sobre as relações que se estabelecem na relação com os espaços, quando diz:

\begin{abstract}
A diversidade dos lugares e das aparências nem se compara à multiplicidade das funções e das práticas de que os espaços privados é ao mesmo tempo o cenário próprio para mobiliar e o teatro de operação. Aqui se repetem em número indefinido em suas minuciosas variações as sequências de gestos indispensáveis aos ritmos do agir cotidiano. Aqui o corpo dispõe de um abrigo fechado onde pode estirar-se, dormir, fugir do barulho, dos olhares, da presença de outras pessoas, garantir suas funções e seu entretenimento mais íntimo. Morar à parte, fora dos lugares coletivos, é dispor de um lugar protegido, onde a pressão do corpo sobre o corpo individual é descartada, onde o plural dos estímulos é filtrado ou, em todo caso, devia sê-lo teoricamente. (p.205)
\end{abstract}

A entrada, "clandestina", num centro acadêmico que vivia às portas fechadas com ares de escritório privado, é outra lembrança desta exploração de um território tanto próprio quanto do outro (neste caso, mais do outro do que 
próprio). Aproveito a saída de um estudante e entro rapidamente, na tentativa de passar despercebida e conseguir capturar as informações expostas nas paredes.

Ora, se trata de um espaço público, cenário do trânsito de passantes entre comunidade interna e externa, o que conferia ares de "estrangeiridade" em alguns espaços e de "receptividade" e "acolhimento" em outros? Que lógicas invisíveis organizavam a circulação dos sujeitos permitindo ou dificultando a livre-circulação pelos espaços "público-privados" da UERJ?

Vale retomar as palavras de Certeau (2011) referindo-se ao território onde ocorrem as "artes de fazer", nos gestos mais elementares, como o espaço doméstico, que o autor denomina de: "a casa da gente".

Aqui todo visitante é intruso, a menos que tenha sido explícita e livremente convidado a entrar. Mesmo neste caso, o convidado deve saber "ficar no seu lugar", sem atrever-se a circular por todas as dependências da casa; deve saber, principalmente, abreviar sua visita, sob pena de cair na categoria (temível) dos "importunos", daqueles que devem ser "discretamente lembrados" das boas maneiras, ou pior ainda, daqueles que devem ser evitados a todo custo, pois não sabem ser convenientes nem manter certa distância. (p.203)

Curioso que cada um dos espaços parece refletir as relações que ali se estabelecem, o que Certeau (2011) chamou no trecho antes destacado de "teatro de operação" (p. 205), palco da multiplicidade de "práticas" e "artes de fazer". É o que fazem parecer os dizeres registrados num informativo escrito pelos gestores de um dos CAs visitados, endereçado aos alunos os quais representavam.

\begin{abstract}
"Sabemos que nem todos os estudantes têm condições de ter video-game em suas residências ou companheiros para o carteado, mas favor não utilizar das salas administrativas do CA para realizar tais atos". A UERJ está rodeada de bares e choperias e temos festas semana sim, semana não, logo não há necessidade de transformar essa sala em mais um local para se consumir bebidas alcoólicas. Basta atravessar a rua. Estudar é algo cansativo, porém há outras maneiras de descansar, além de se deitar. O melhor exemplo é sentar. Seja forte. Já, já você se forma, ou não. O amor é o sentimento mais saudável que podemos ter e sabemos que expressá-lo é natural. Entretanto não faça nada dentro das dependências do CA que você não faria na frente dos seus pais. Controle o tom da sua voz, não precisamos gritar para sermos entendidos. Se estiver conversando com alguém que não escute, faça mímica ele é surdo, gritar não ajudará."
\end{abstract}

É como mais uma vez nos faz pensar Certeau (2011):

Mesmo um quarto de hotel, anônimo, diz muito sobre seu hóspede de passagem no fim de algumas horas. Um lugar habitado pela mesma pessoa durante um certo tempo esboça um retrato semelhante, a partir dos objetos (presentes ou ausentes) e dos costumes que supõem. $O$ jogo das exclusões e das preferências, disposição do mobiliário, a escolha dos materiais, a gama de formas e de cores, as fontes de luz, o reflexo de um espelho, a ordem e a desordem, o visível e o invisível, a 
harmonia e as discordâncias, a austeridade ou a elegância, o cuidado ou a negligência, o reino da convenção toques de exotismo e mais ainda a maneira de organizar o espaço disponível, por exíguo que seja, e de distribuir nele as diferentes funções diárias (refeições, toalete, recepção, conversa, estudo, lazer, repouso) tudo já compõe um "relato de vida", mesmo antes que o dono da casa pronuncie a mínima palavra. (p.204)

\subsubsection{Os Fluxos e Relatos de um Itinerante-Fotógrafo}

\section{A) Eleições estudantis para o DCE/2009...}

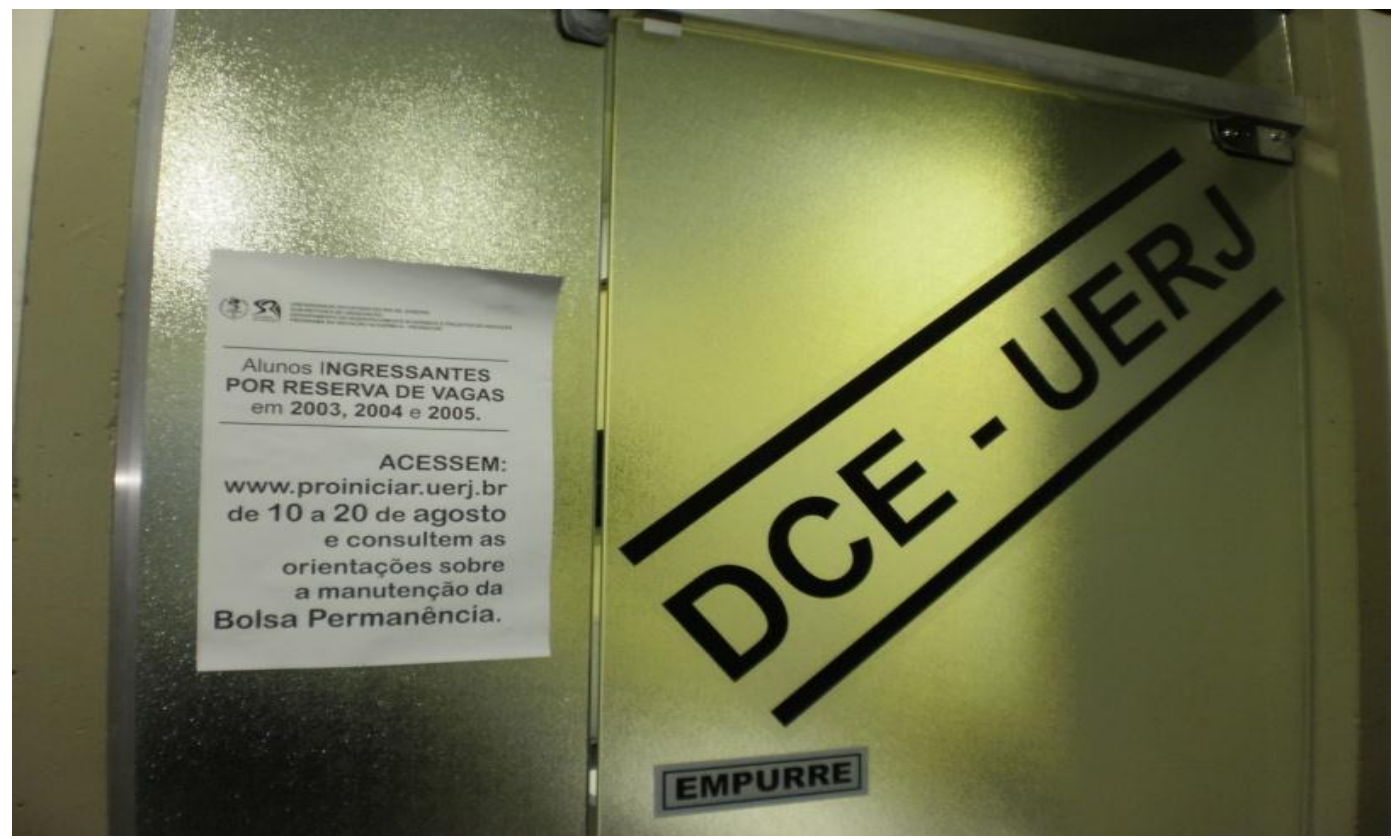

Foto 30 - Entrada do Diretório Central dos Estudantes. No vidro, um cartaz do Proiniciar, com informações sobre renovação e documentação referentes à bolsa dos estudantes "cotistas".

Díario de bordo $\sigma^{46}$ : Terça, novembro de 2009. Começo $\sigma$ día de trabatho na UERJ e de pesquisa também. 07:00h. Turno da manhã. Chego no hall dos elevadores e logo sou recebida por alunos entregando jornais e fazendo campanha. Era semana de eleição para o Diretório Central de Estudantes (DCE). Estudantes falavam de suas propostas, uns apontavam falhas nas chapas de oposição e entregavam jornais. Entro no elevador e presencio uma conversa entre alunos sobre a eleição: "De que lado você samba?" pergunta um estudante pra um colega em tom de brincadeira. ("de que lado você samba" era o nome de uma das chapas que concorria ao DCE). Chego ao destino.

\footnotetext{
${ }^{46}$ Nos trechos referentes ao diário de bordo, optou-se por uma fonte diferenciada, com vistas a garantir um aspecto de informalidade, peculiar à escrita do diário de bordo.
} 
Uma avalanche de jornais é distribuída pelos alunos nos acessos de maior circulação, saídas das rampas para os andares, dos elevadores, entradas principais, salas de aula.

"De que lado você samba? Por um DCE independente?" Esta chapa trazia, dentre outros, o tema das cotas como pauta de campanha. Era possível ver como as equipes candidatas, situação e oposição, posicionavam-se na intenção de agregar mais eleitores para suas chapas. Vejamos alguns dos conteúdos dos jornais desta primeira chapa citada:

"Cotas sim! Em 2009 vimos um triste episódio em que o deputado Flavio Bolsonaro (PP) encaminhou à justiça o pedido do fim do sistema de cotas nas universidades estaduais. Segundo ele, as cotas são discriminatórias e não cumprem seus objetivos. Não concordamos com isso e achamos que as cotas cumprem sim um papel fundamental. Permite o acesso na universidade da população negra, que é mais da metade da população, e que sofreu (e ainda sofre!) uma histórica e cruel exclusão sócio-econômica. Em protesto a tal medida, nossa gestão (nada será como antes) participou e organizou mobilizações junto aos movimentos negros fora e dentro da UERJ".

"Vitórias para os cotistas! Defensores das cotas aqui na UERJ temos muitos... o Reitor (e sua chapa pro DCE), O Governo Federal, Estadual (esse temos dúvidas!)... porém na prática estes não garantem a permanência dos cotistas na universidade. Na nossa gestão, conseguimos vitórias importantes: a possibilidade de acúmulo de mais de um tipo de bolsa(que ano que vem entrará em vigor) e garantia de bolsa do Proiniciar até o fim da faculdade (lei 5230/2008). A política de cotas tem e deve estar colada a uma real assistência ao cotista, diferente do que tem ocorrido aqui na UERJ.

"Que vergonha! A chapa 1 diz defender as cotas aqui na UERJ mas não foi isso que vimos lá na eleição do DCE da UFRJ. Alguns dos "cabeças" dessa chapa apoiaram e fizeram campanha explicitamente para a chapa 5 "unidos pela UFRJ, contra as cotas". Cadê a coerência, chapa 1? Afinal, de que lado vocês sambam?"

"Propostas! Em defesa do sistema de cotas; Cotas com qualidade! Maior e melhor assistência aos cotistas; Reitoria! Garanta o acúmulo de bolsas para os cotistas; Pontualidade da bolsa Proiniciar; Mais materiais para os cotistas".

"Mais pela UERJ! Contra o machismo, homofobia e racismo na UERJ".

A chapa 1 - "Um novo enredo" traz como mote de campanha o slogan: "é chegada a hora de fazermos valer nossa voz!" e apresenta, no jornal de campanha, o seguinte posicionamento:

"A manutenção do sistema de cotas e a possibilidade dos alunos cotistas concluírem seus cursos são questões primordiais para garantirmos a democratização da Universidade. Tanto os negros quanto os estudantes oriundos de escolas públicas representam parcela da sociedade que historicamente ficaria fora da educação superior. Neste sentido as ações afirmativas servem para superar tais desigualdades. Parcelas conservadoras e elitistas da sociedade 
tentam a todo instante biocotar essa política e, através do poder judiciário, derrubá-la, desrespeitando a autonomia da universidade. Precisamos estar atentos e preparados para defender as cotas e fazer com que continuem sua trajetória de ampliação do acesso ao ensino superior e enriquecimento da produção acadêmica a partir da diversidade das realidades e pluralidade de ideias existentes no Rio de Janeiro".

Enquanto nos elevadores, nos corredores e arredores, o debate fervilhava entre as chapas concorrentes trazendo, dentre outras temáticas, o tema das cotas como pauta de campanha eleitoral, nas salas de aula os estudantes e integrantes dos movimentos proferiam seus discursos e acaloravam as discussões.

B) UERJ, CERTA TERÇA-FEIRA, 21:00H

Recebo, frequentemente, alunos solicitando um espaço das aulas para fazer campanhas para os Centros Acadêmicos e para o DCE. Nos jornais, as propostas de campanhas das chapas concorrentes.

Diárío de bordo: Terça-feira, 21:00h. Começo a me organizar para dar inicio à aula. Os alunos vão entrando, cansados em função do horário avançado. Muitos vinham de um longo dia de trabalho que terminava nas salas de aula da faculdade. Um grupo de estudantes se aproxima à porta pedindo licença para falar com a turma. Era de uma das chapas que concorria ao DCE. A turma pedia em coro que não permitisse a entrada dele em sala. Situação complicada, pois os estudantes-militantes insistiam em falar com a turma e em vistas de considerar $\sigma$ espaço da universidade como importante para promover discussões e participações dos alunos nas questöes que dizem respeito aos rumos da universidade e da sociedade de um modo mais amplo. Entretanto, o espaço da sala de aula também deve ser preservado para as discussöes acadêmicas. Permito 5 minutos. Começam a falar de suas propostas, mas logo em seguida partem para criticas às propostas da chapa de oposição, ausente. Acusações de associações possiveis da outra chapa com a atual gestão da reitoria da universidade. Festa de confraternização supostamente financiada pela reitoria... questão das cotas surge... grande foco da campanha, ao que faz parecer. Acusações de serem contrários às cotas e de associação à parte do movimento estudantil da UFRJ que se posiciona contrário às cotas... quando de repente um aluno da turma interrompe e pede a palavra fazendo algumas perguntas à chapa presente. Nitidamente, este aluno apoiava a chapa contrária, ou seja, aquela que estaría sendo alvo de criticas pelo grupo. Um dos integrantes da chapa afirma: "Me parece que $\sigma$ 
colega aqui presente apoia a chapa de oposição e ew acho que esse não é $\sigma$ espaço pra um debate. Podemos conversar lá fora pra não atrapalhar a aula da professora". Naquele momento, independente da posição de uma ou outra chapa, senti-me angustiada e tomada por um senso de justiça. Era direito do aluno replicar e posicionar-se em defesa do grupo que apoiava, tendo em vista que um outro grupo entra na sala de aula pra proferir criticas e não somente para falar das propostas e/ow plataformas politicas de seu grupo. Dé um espaço pro aluno se posicionar e precisei encerrar a discussão. A aula precisava continuar e de fato esse não era, naquele momento específico, $\sigma$ espaço pra isso.

C) UERJ, 32 de agosto, 1 e 2 de setembro

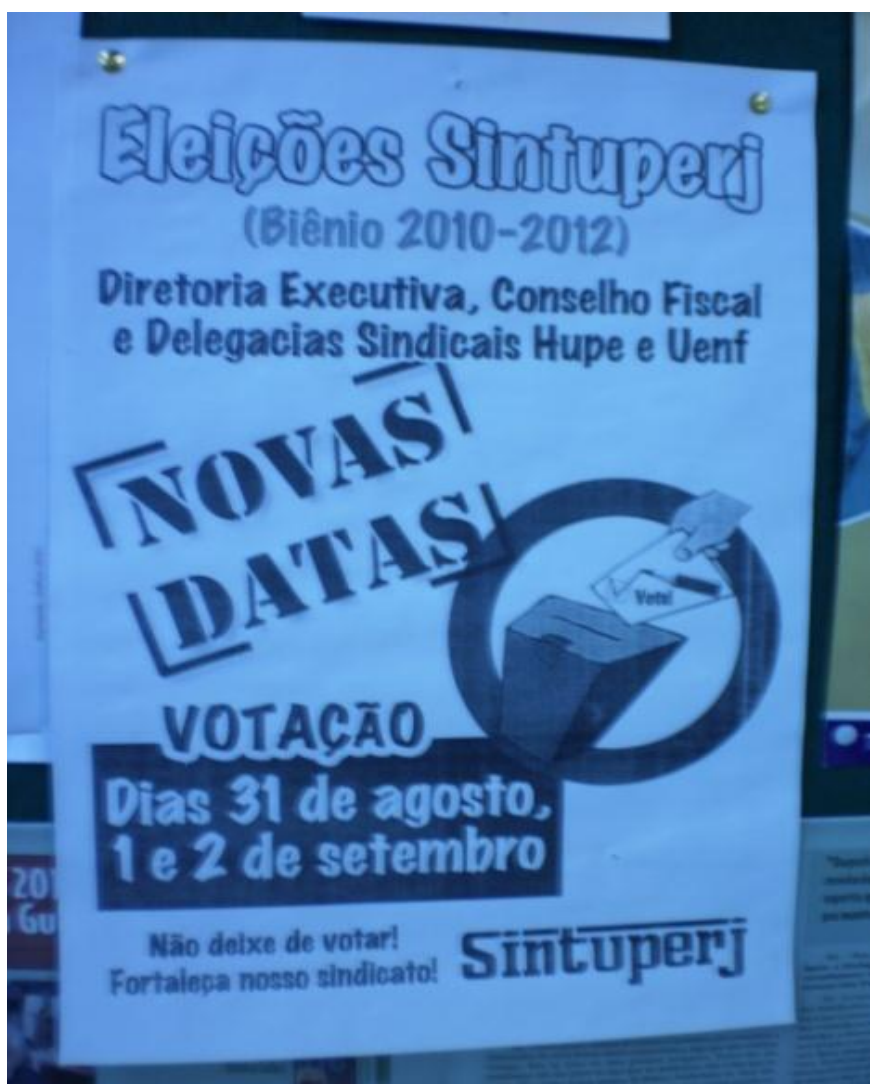

Foto 31 - Cartaz/Sintuperj

Chega o momento das eleições para o Sindicato dos Trabalhadores da UERJ/Sintuperj. Os jornais são além de distribuídos, colados nas paredes da Universidade, nos espaços mais inusitados. Dentre as pautas de campanha, aparece a temática da política de reserva de vagas. O sindicado parece bastante implicado com o tema, uma vez que possui a ele vinculado um curso pré- 
vestibular comunitário que funciona dentro do espaço da UERJ. É o que indica os jornais de campanha aos quais começo a ter acesso, à época.
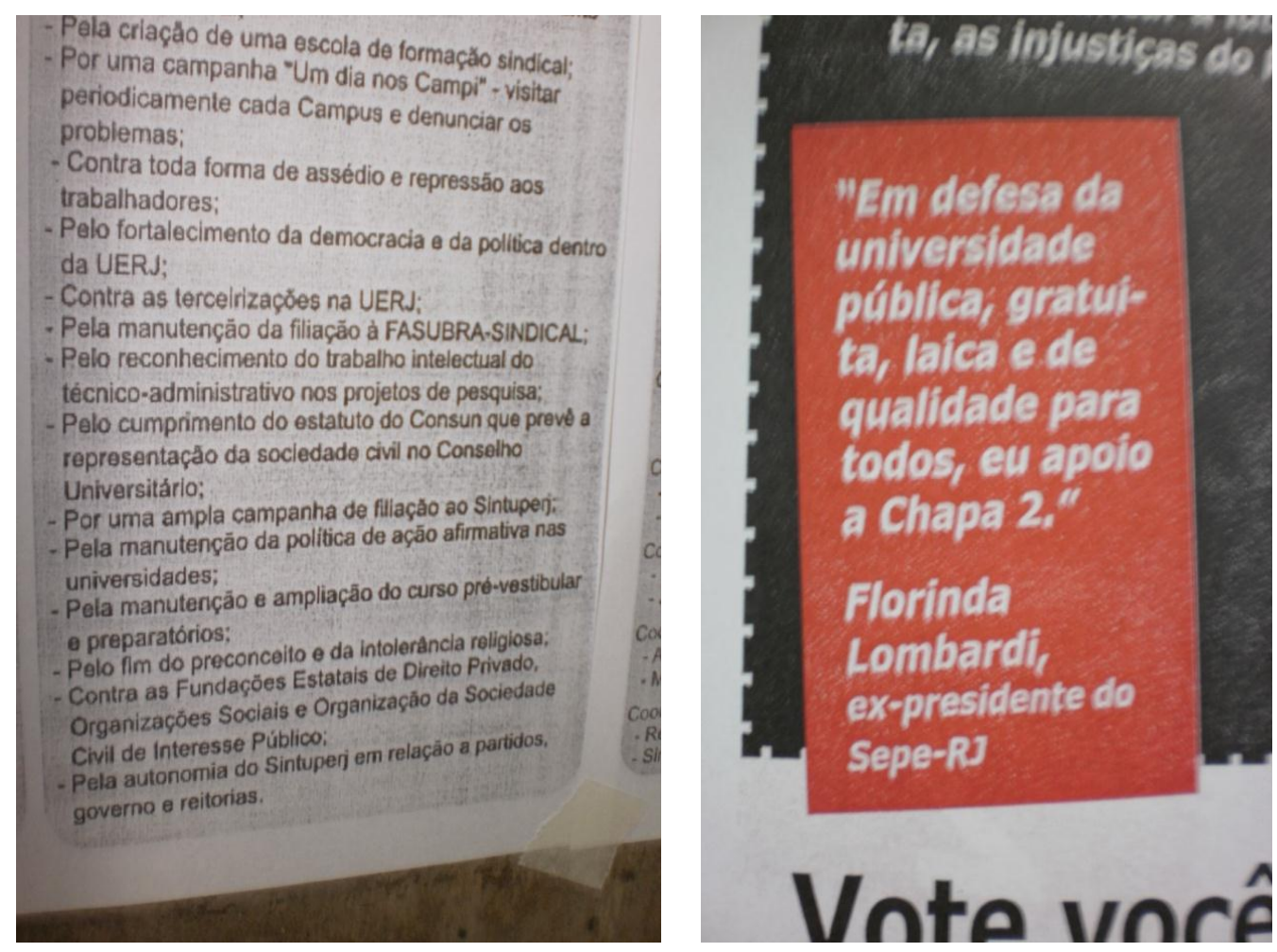

Foto 32 (chapa 1): Ousar e Lutar

Foto 33 (chapa 2): Resistência e Alternativa

\section{D) Eleições estudantis para os CAs}

Os Centros Acadêmicos da Universidade entram em processo eleitoral. Nos corredores são colados cartazes, com escritos e desenhos. Os candidatos à representação estudantil dos cursos publicizam suas posições. Os embates e diferentes posições podem ser acompanhados pelas paredes. Situação e oposição dialogam através de cartazes e, dentre os vários temas em torno dos quais os debates se configuram, aparece recorrentemente o da política de cotas. Em meio aos temas, alguns relativos à experiência da reserva de vagas: material dos cotistas e sua distribuição, posições favoráveis ou desfavoráveis às cotas, assistência estudantil (funcionamento do bandejão), acúmulo de bolsas para os estudantes cotistas, entre outras.

Não há como não participar. Em semana de processo eleitoral para as gestões dos CAs, vários cursos preenchem os espaços das paredes de "seus" corredores com cartazes, charges criativas, desenhos, questionários irreverentes, palavras de ordem. Os vários cursos se encontram em campanha 
no mesmo período, início do semestre e mudança nas gestões dos CAs. Propusme a acompanhar o fluxo de movimentos de três cursos que mais me chamaram a atenção pelas suas campanhas acaloradas e explícitas nos corredores: o curso de direito (Centro Acadêmico Luiz Carpenter/CALC), o Curso de Educação Física (Centro Acadêmico de Educação Física/CAEFALF) e o Curso de Pedagogia (Centro Acadêmico Paulo Freire/ CAPF).
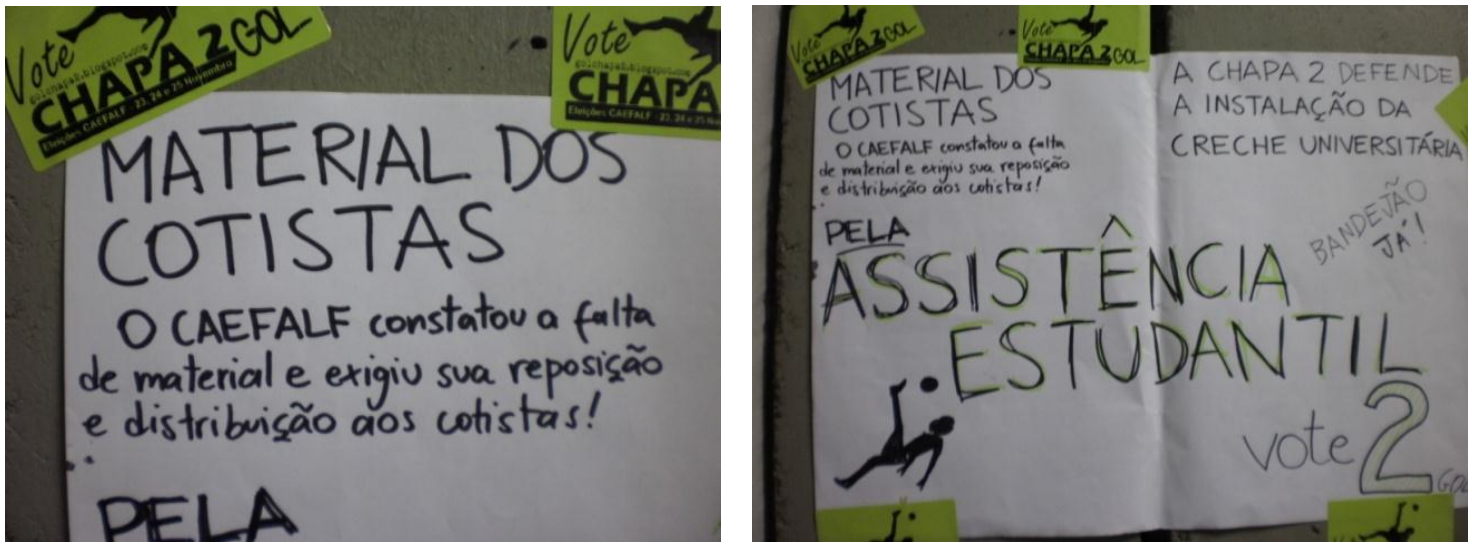

Fotos 34 e 35 - CAEFALF - Hall das salas de aula, nono andar, referente ao processo eleitoral para gestão do centro acadêmico do curso de educação física.
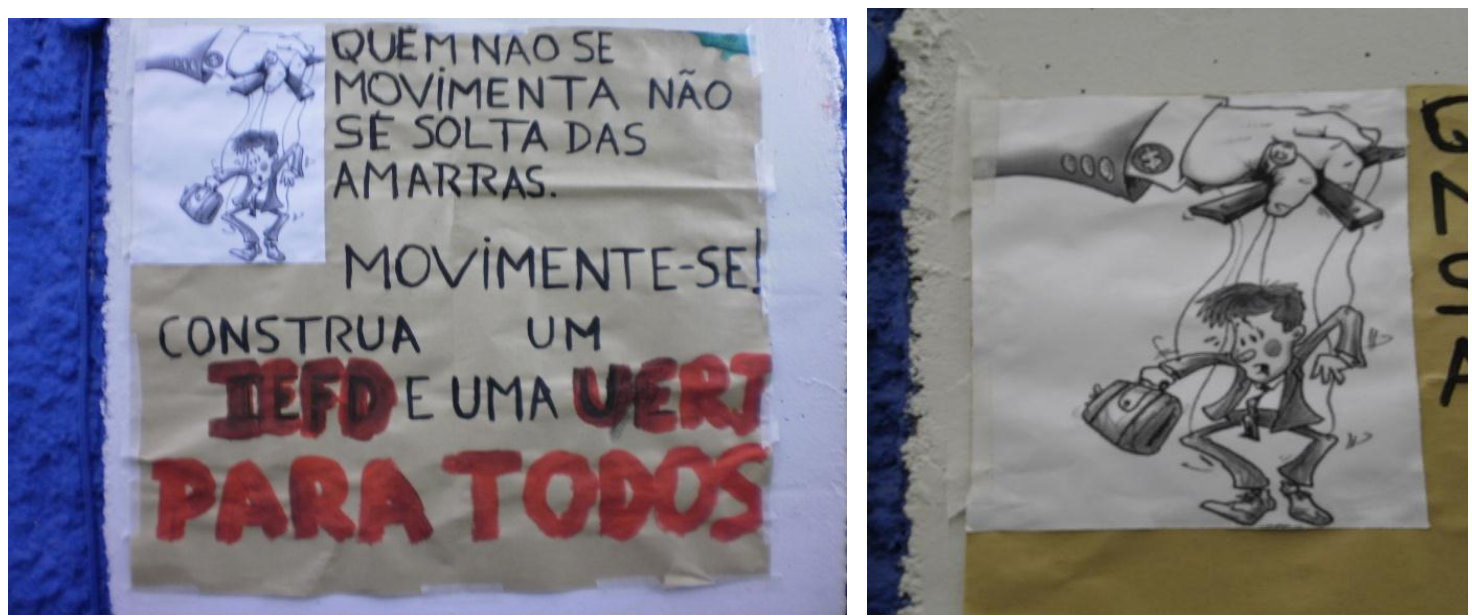

Fotos 36 e 37 - Tiradas nas paredes da lanchonete onde se localiza a sala do centro acadêmico do curso de educação física. 

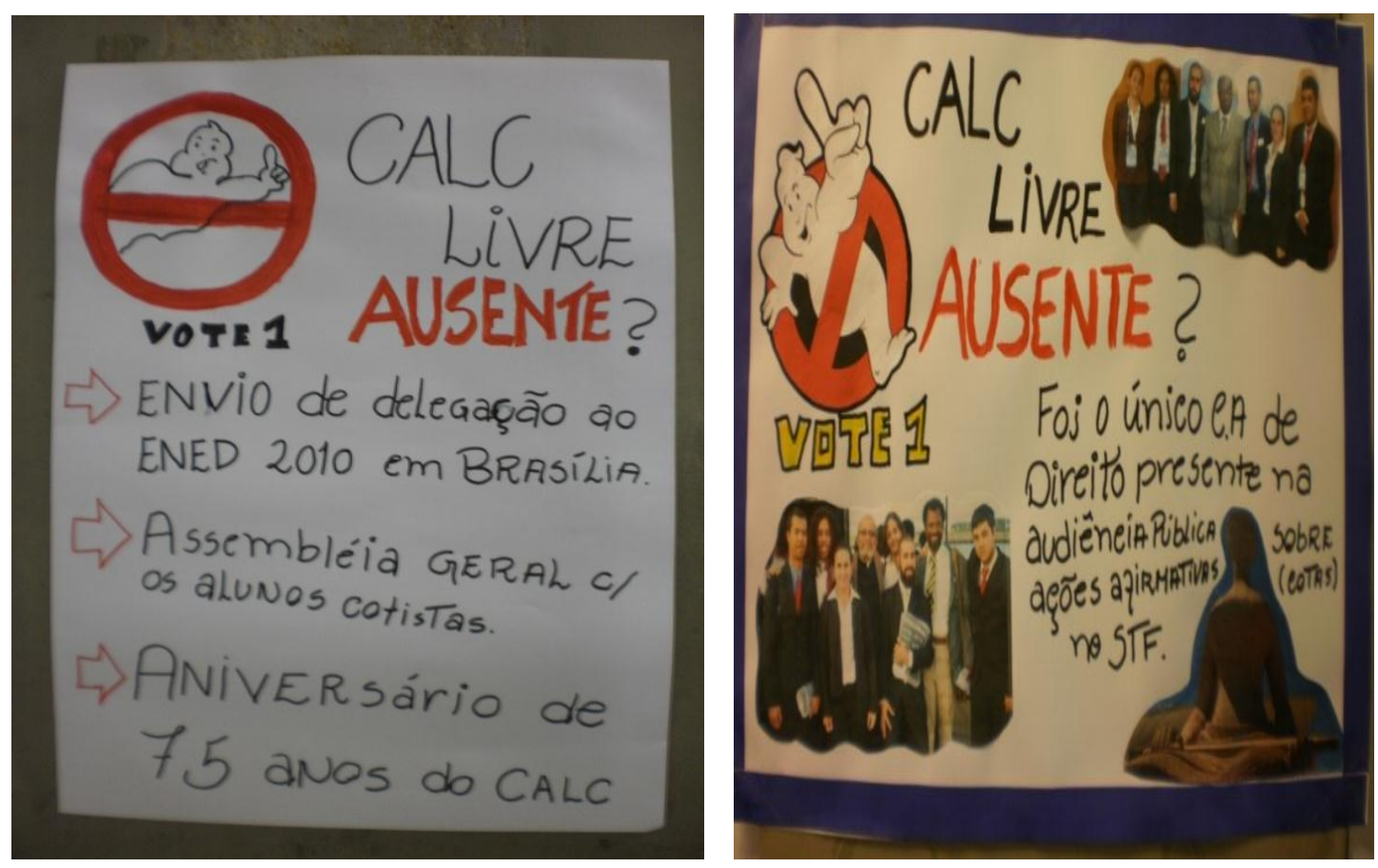

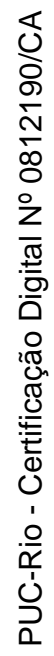
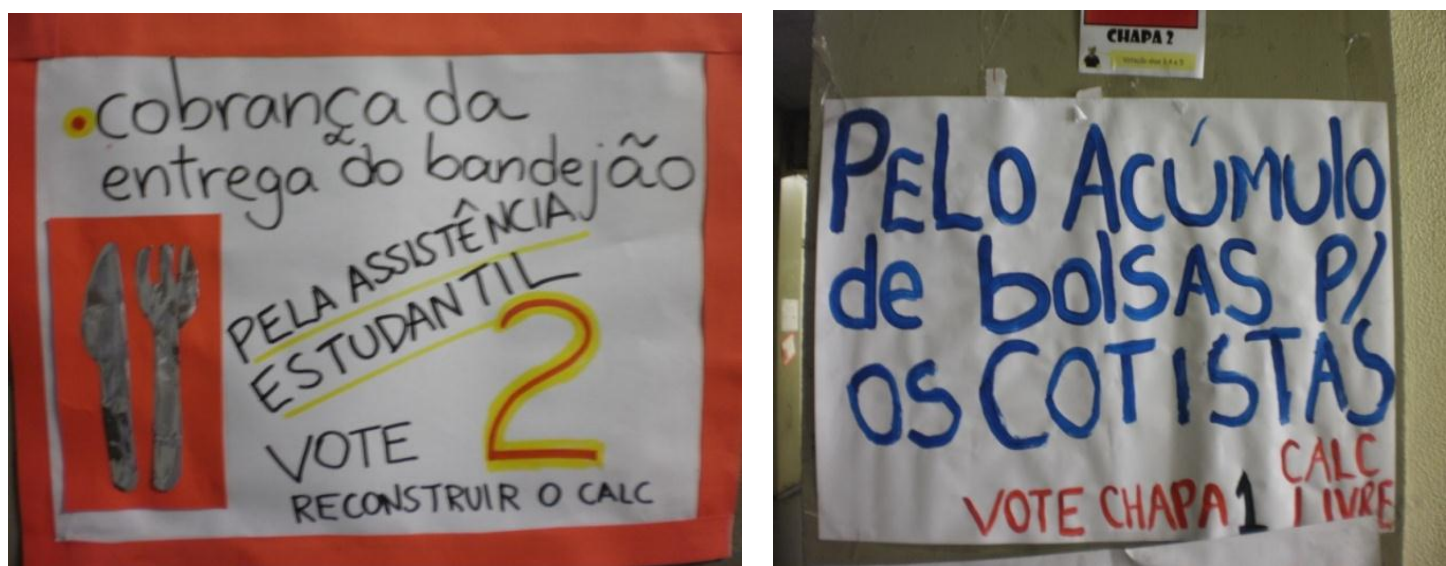

Fotos 38, 39, 40 e 41 - CALC - Corredor das salas de aula do curso de Direito 

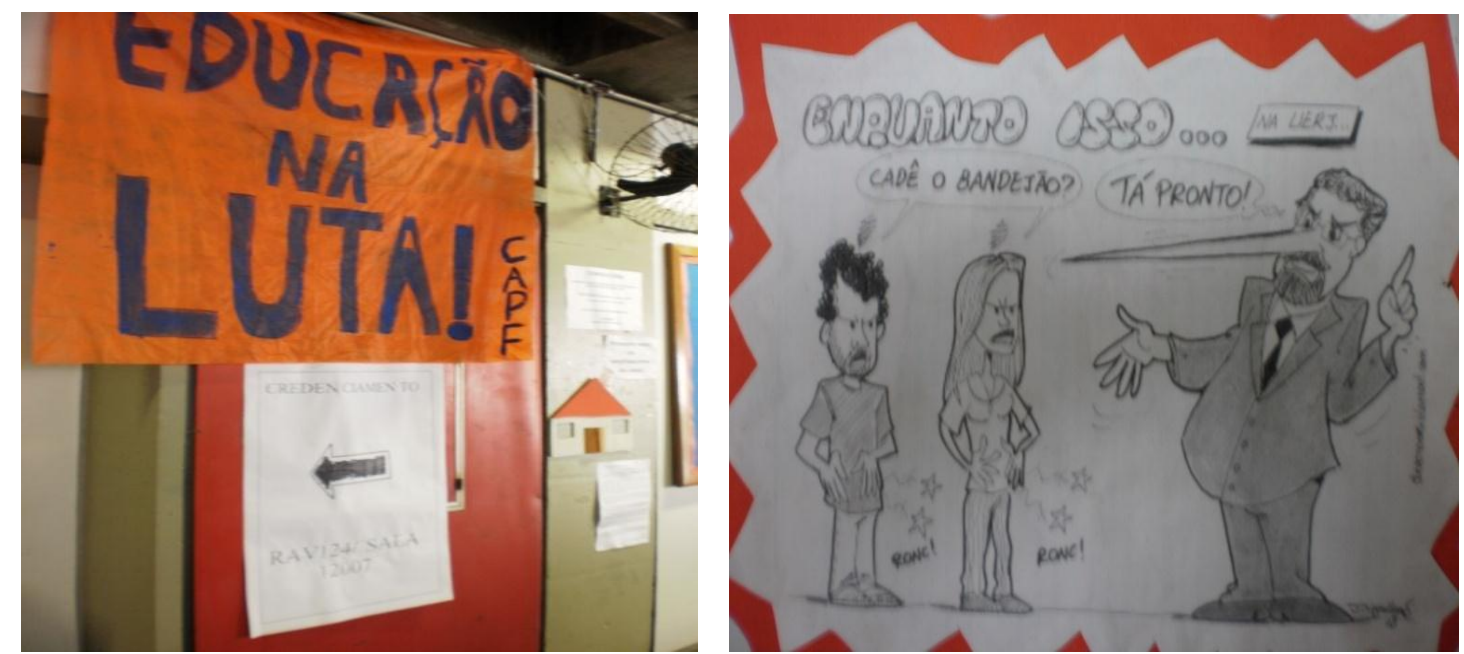

Fotos 42 e 43 - CAPF - Corredor do $12^{\circ}$ andar - curso de pedagogia
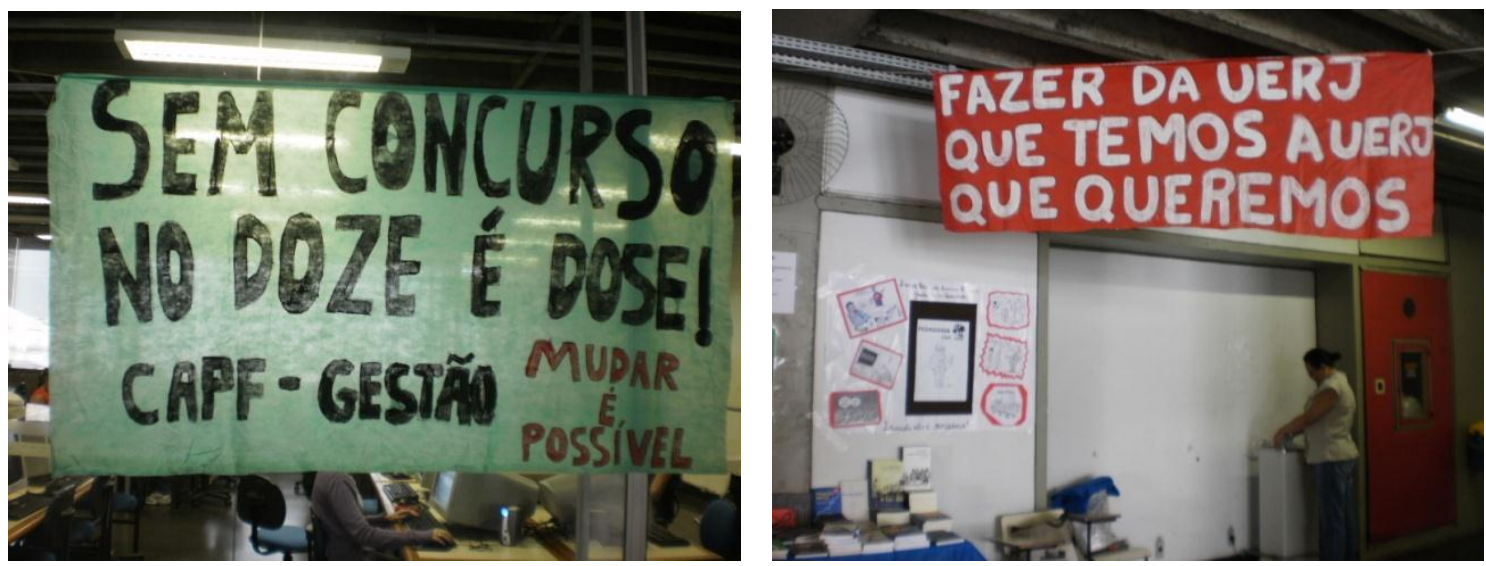

Fotos 44 e 45 - CAPF - Corredor do $12^{\circ}$ andar - curso de pedagogia. 


\section{E) Processo Eleitoral no Brasil}

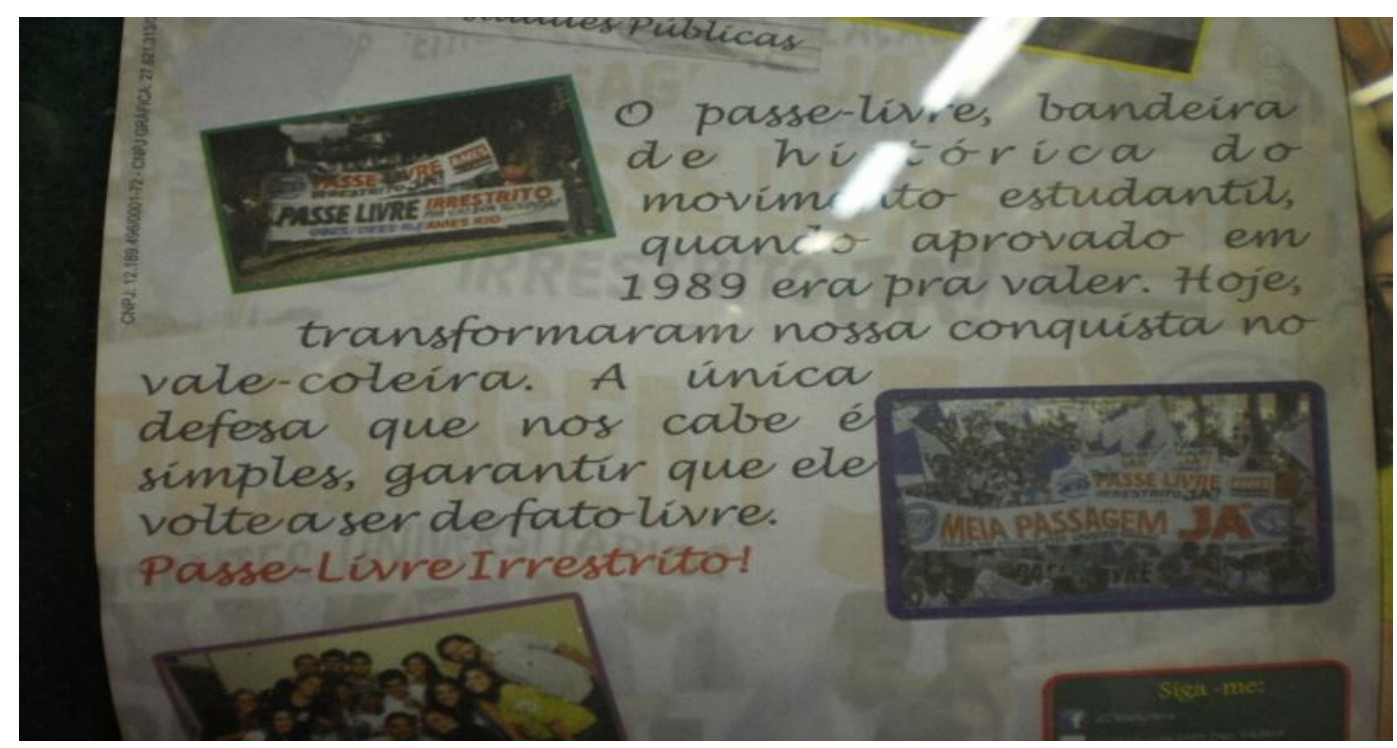

Foto 46 - Mural do primeiro andar, entrada dos elevadores.

Momento de processo eleitoral no país. Panfletos são expostos nos murais referentes aos partidos políticos, no hall de entrada. Põem-se à mostra as plataformas políticas de candidatos interessados em ganhar votos, mencionando temáticas de interesse dos estudantes, dentre elas, as subjacentes à discussão da reserva

de vagas.

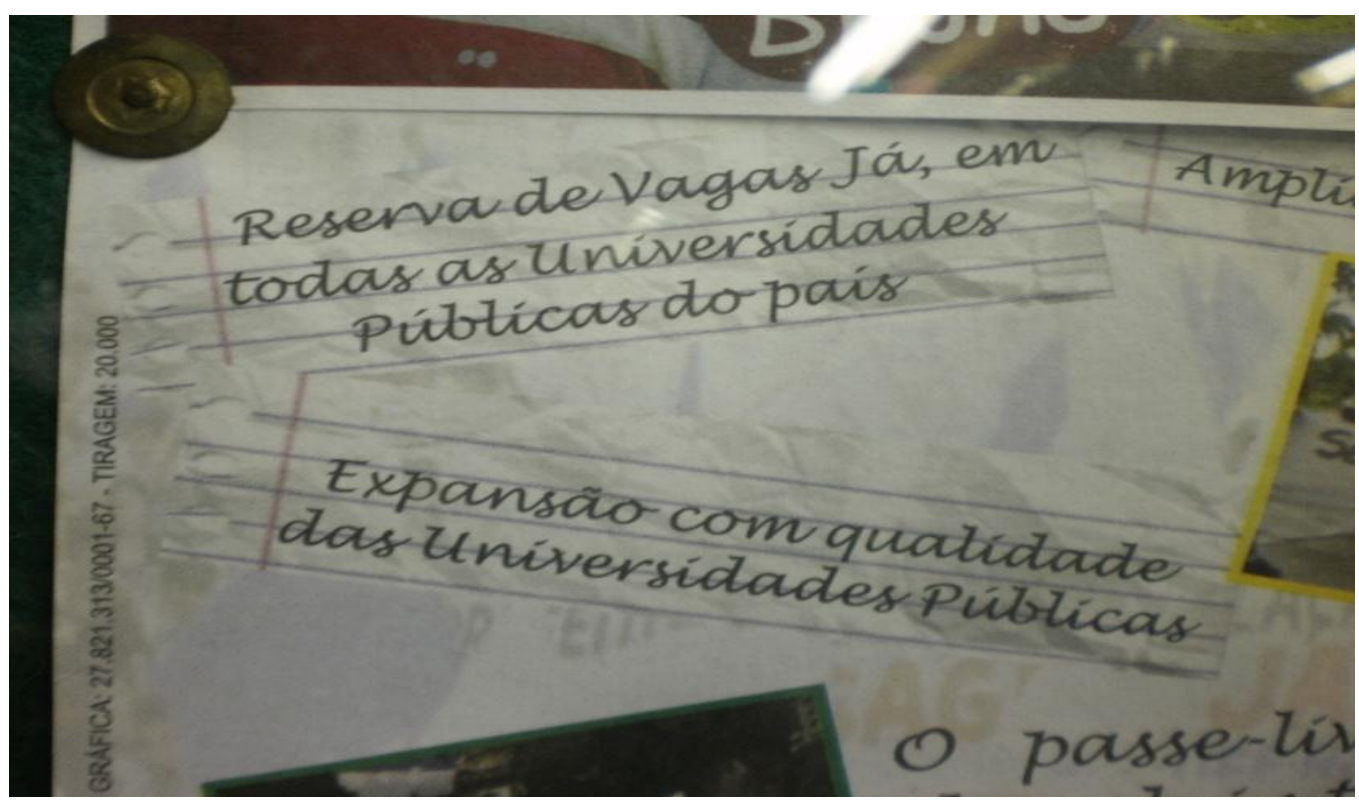

Foto 47 - tirada do quadro de partidos políticos no primeiro andar, entrada dos elevadores. A defesa do passe livre encontra-se em um jornal de campanha de determinado candidato. 
As fotos acima foram extraídas de um quadro localizado no primeiro andar da UERJ, relativas à campanha de alguns candidatos e a partidos políticos específicos. Pelo que se pode verificar, as temáticas mais recorrentes nos panfletos, jornais e debates promovidos neste período eleitoral na instituição relacionavam-se com: os projetos das UPPs (Unidade de Polícia Pacificadora) no Rio de Janeiro; gratuidade de transportes para os estudantes - o passe livre e políticas de assistência estudantil - bandejão, especificamente. O tema da política de cotas foi pouco tratado de modo mais explícito.

\section{F) 5, 6, 7 de outubro: Arte e política nas ciências sociais}

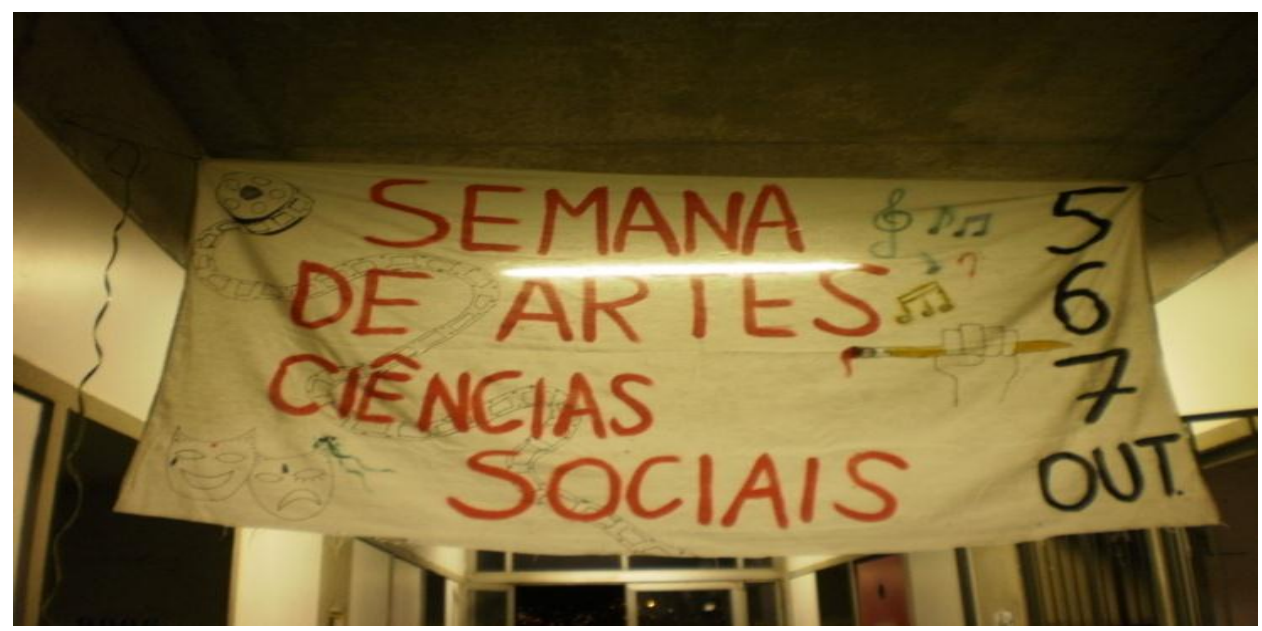

Foto 48 - Corredor do curso de ciências sociais

O hall do $9^{\circ}$ andar, certo dia, ganha um colorido peculiar. Banners e cartazes interpelam os passantes com um misto de poesias, charges, maquetes, anúncio de palestras e eventos culturais por toda uma semana. É a semana cultural das ciências sociais. 


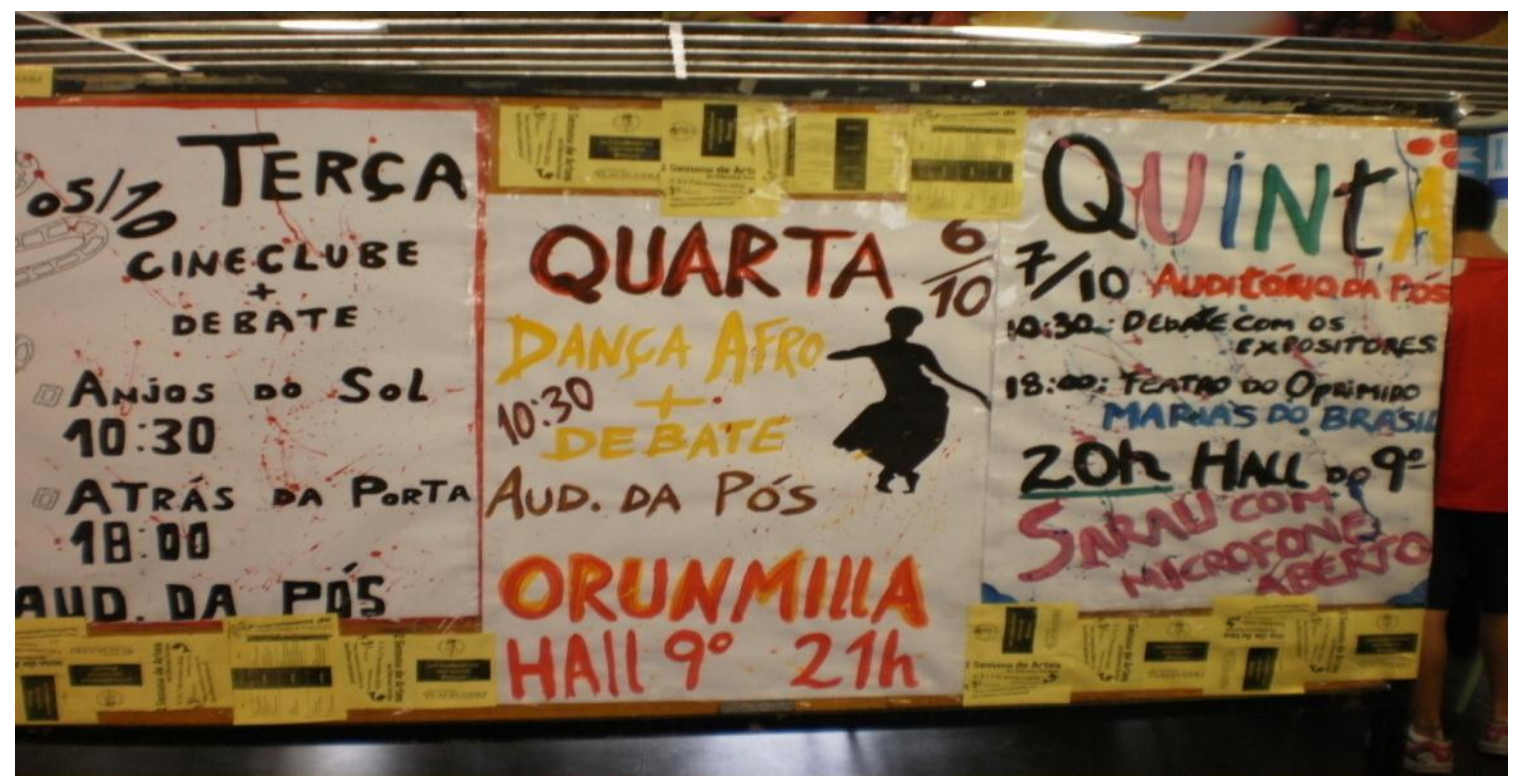

Foto 49 - Hall do 9o andar

Arte e política de misturam com modos irreverentes de expressar os posicionamentos dos estudantes frente aos temas da: violência, política, corrupção, racismo, preconceito, produção de conhecimento, função da universidade, etc, e se refletem nos corredores do andar intitulado pelos CAs dos cursos de história, filosofia, ciências sociais, como "a república socialista do $9^{\circ}$ andar".

Um quadro informativo anuncia a programação cultural da semana de arte das ciências sociais, incluindo sarau, cineclube com debates, peça de teatro, apresentação de dança afro, etc.
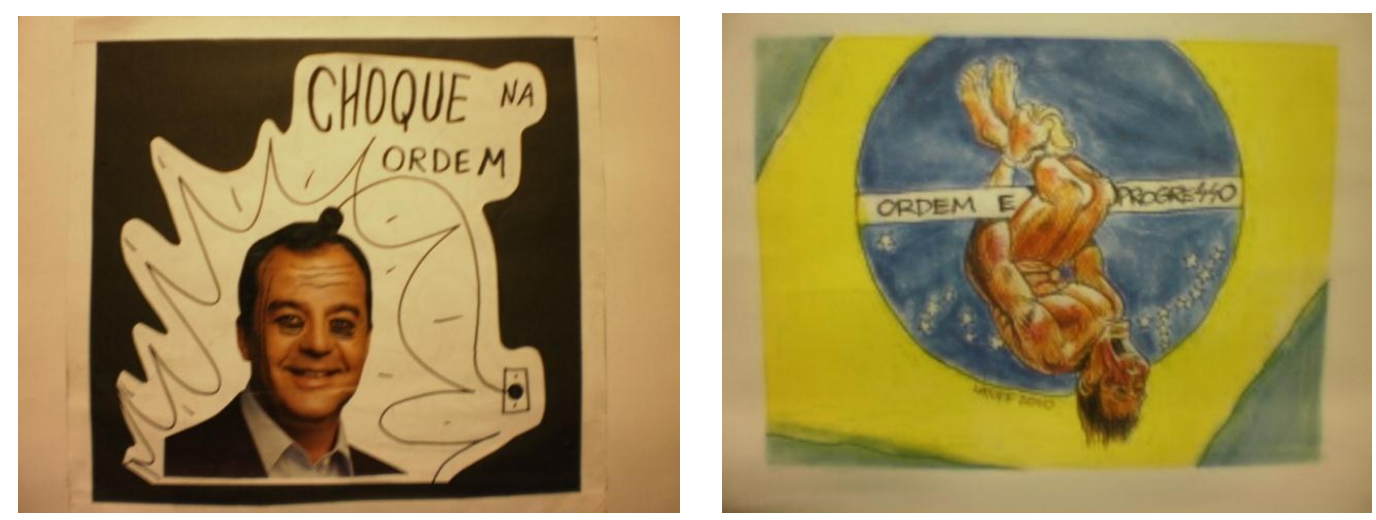

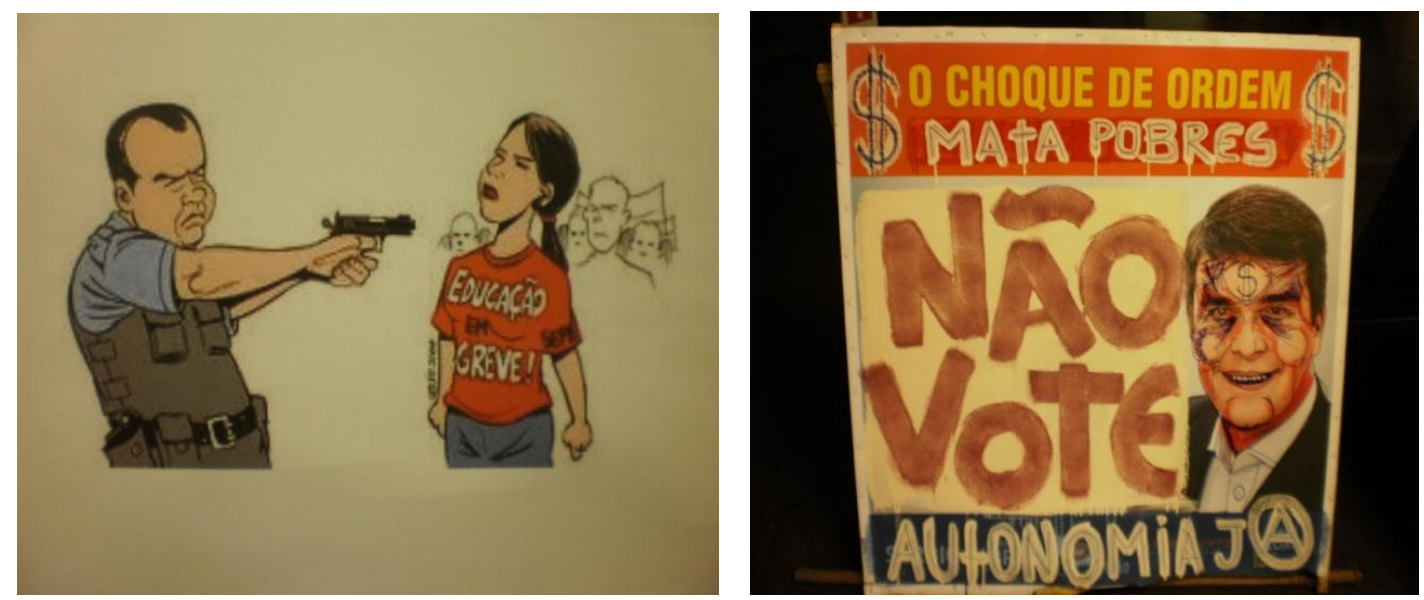

Fotos 50, 51, 52 e 53. Estas imagens se encontravam em banners em exposição nos corredores da UERJ durante a semana de arte organizada pelos estudantes do curso de ciências sociais.

G) Ensino, pesquisa e extensão: A UERJ SEM MUROS
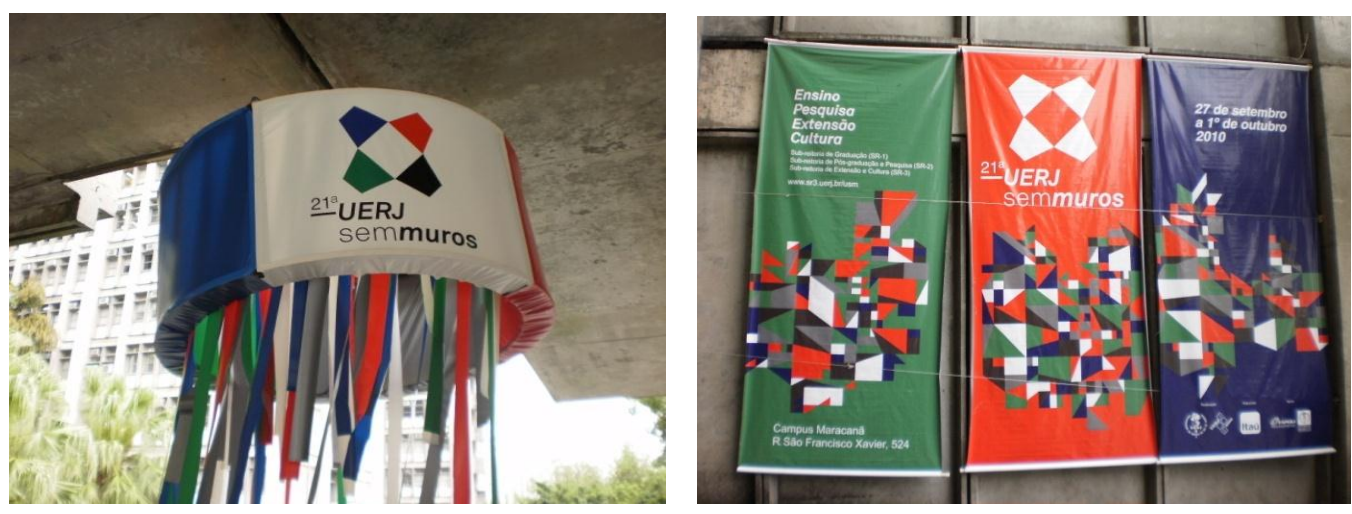

Fotos 54 e 55 - Entradas da UERJ (entrada principal e corredor de acesso ao metrô)

O evento da "UERJ sem muros" é o espaço aberto pela universidade para exposição e apresentação de trabalhos em andamento por estudantes de todos os cursos da instituição. Palestras, workshopps, apresentação de pesquisas científicas, painéis, tomam conta da UERJ durante três dias de eventos consecutivos. Alguns dos estudantes trabalham como voluntários do evento, na organização e suporte técnico, sob a coordenação e supervisão dos setores administrativos da instituição, responsáveis também pela realização do evento. 


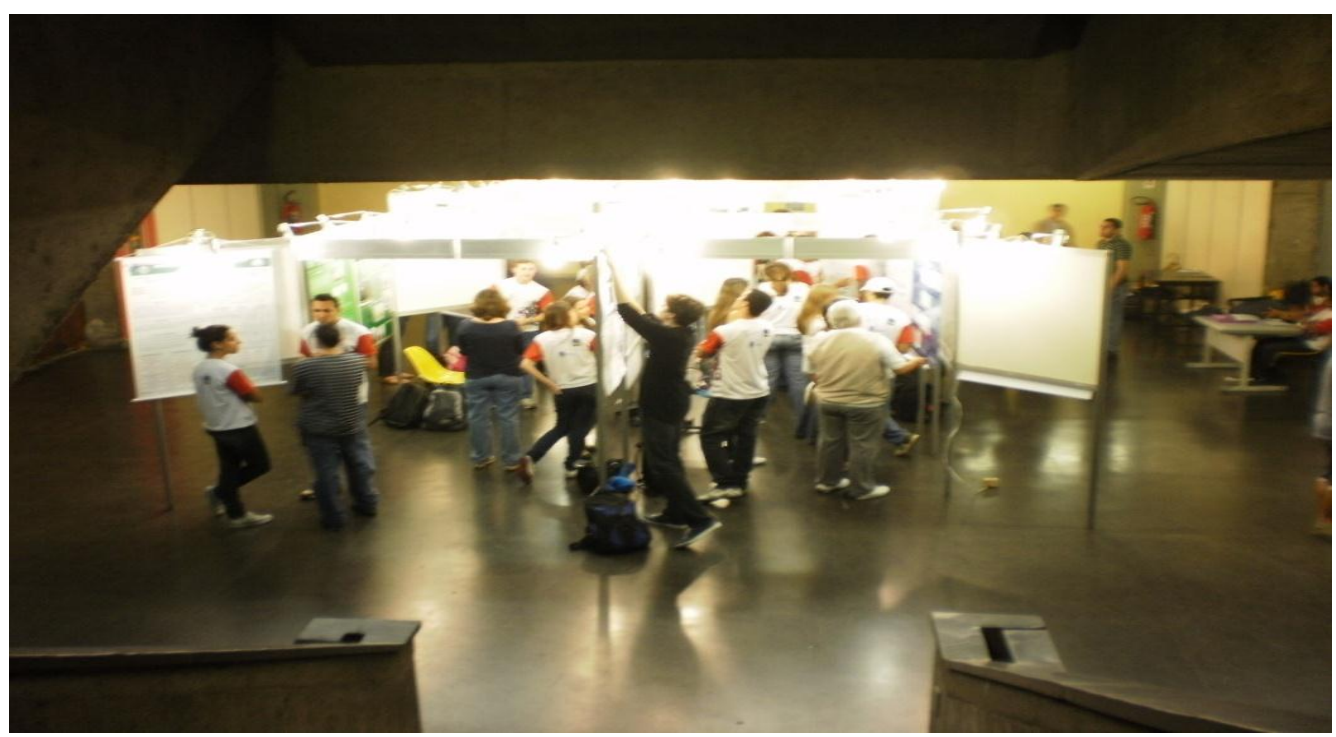

Foto 56 - Hall do segundo andar.

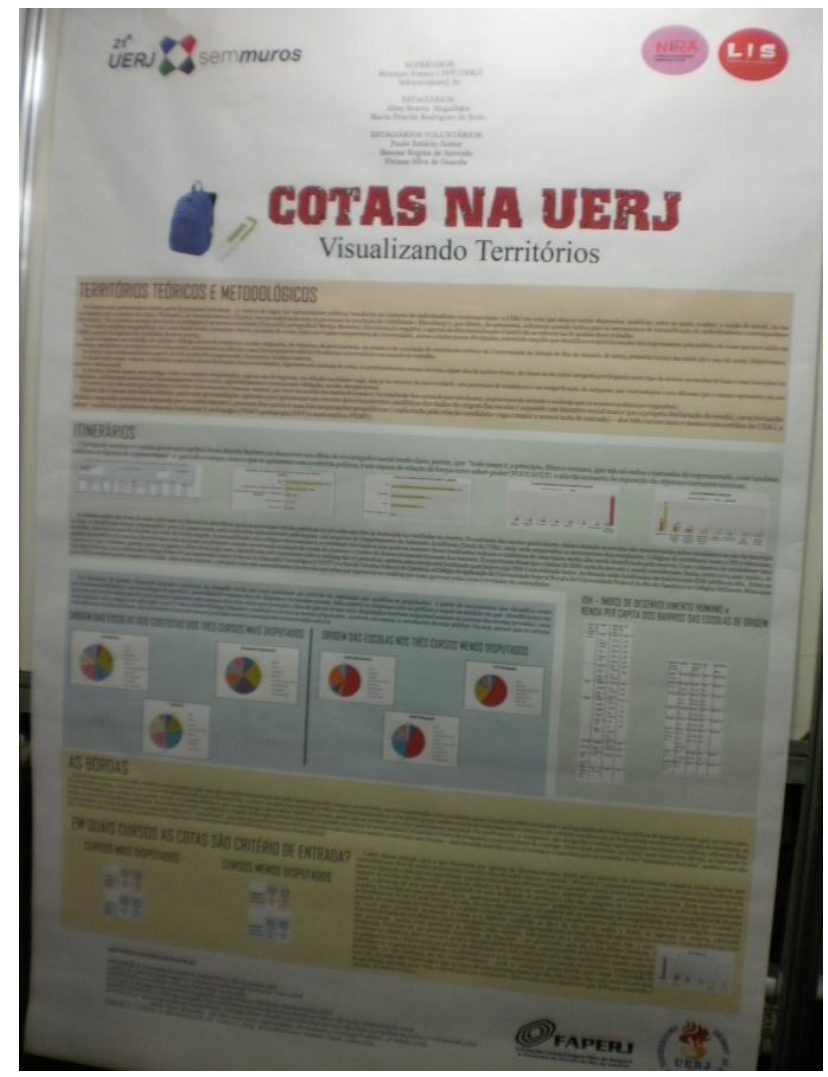

Foto 57 - Painel exibido no evento da "UERJ sem muros" por um grupo de pesquisa formado por estudantes da UERJ/Campus/São Gonçalo. O tema do trabalho é "Cotas na UERJ: Visualizando Territórios". 
H) O curso pré-vestibular comunitário na UERJ

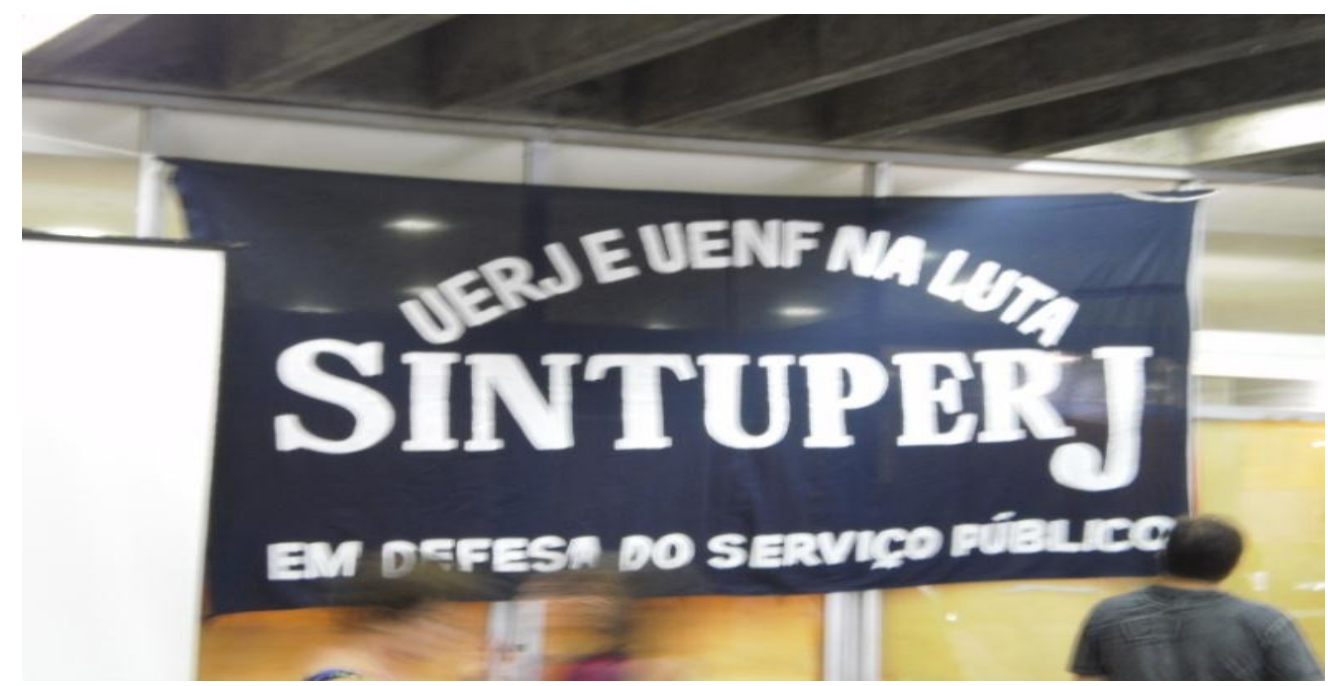

Foto 58 - Primeiro andar/hall dos elevadores. Sintuperj - Sindicato dos Trabalhadores da UERJ, coordenador e idealizador do curso pré-vestibular coimunitário da instituição.

Díário de bordo: Certo dia, após as aulas na UERJ no turno da manhã, me deparo com um aglomerado de pessoas no hall dos elevadores com músicos e cartazes do Sintuperj. $O$ sindicato dos funcionários, ao que parecia, realizava um evento em comemoração aos anos de criação do pré-vestibular comunitário da UERJ, coordenado pelo Sintuperj. Este curso funciona nas intermediaçöes do sindicato e tem proporcionado a inserção de jovens nas universidades públicas e privadas do pais.

I) $A$ rede pública de ensino de base na UERJ

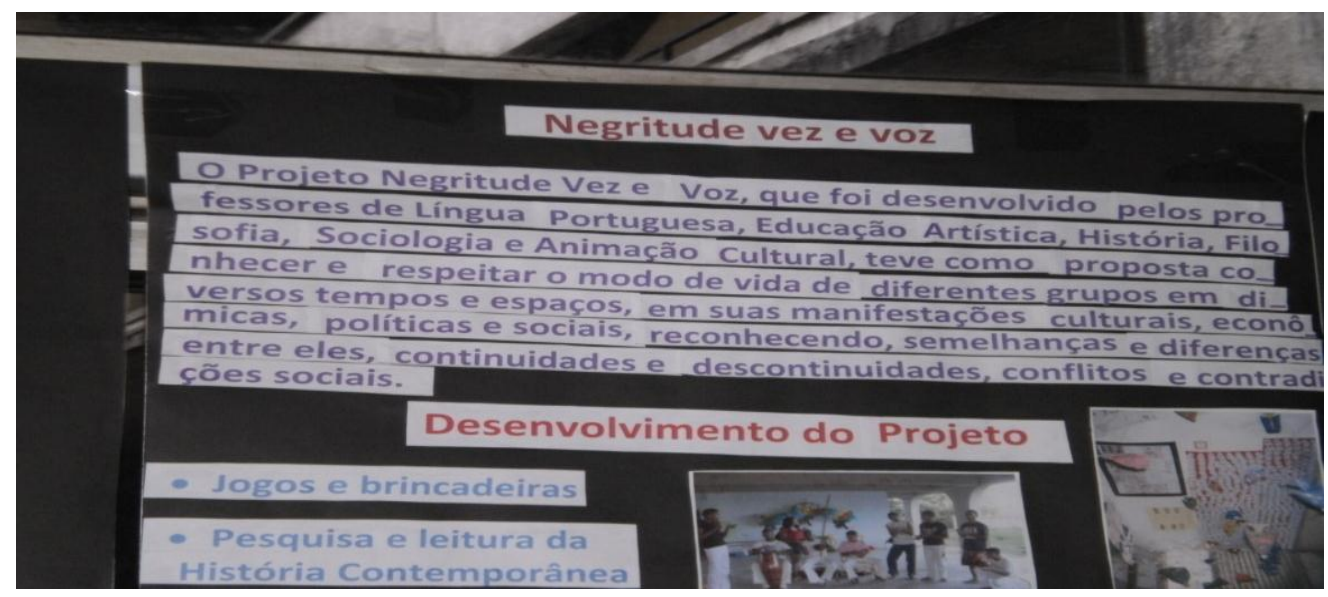

Foto 59 - Cartaz de uma escola da rede pública de ensino exposto no hall do terceiro andar da UERJ 
Andando pela UERJ munida da máquina fotográfica e do diário de bordo ferramentas de pesquisa - me deparo com um evento que toma o hall do terceiro andar da universidade de cores, banners e cartazes, tratando do tema do racismo. Dentre as imagens e exposições culturais, o evento traz uma especificidade: a participação de alunos da rede pública de ensino, provenientes do ensino fundamental e médio, na confecção dos materiais e do próprio evento.

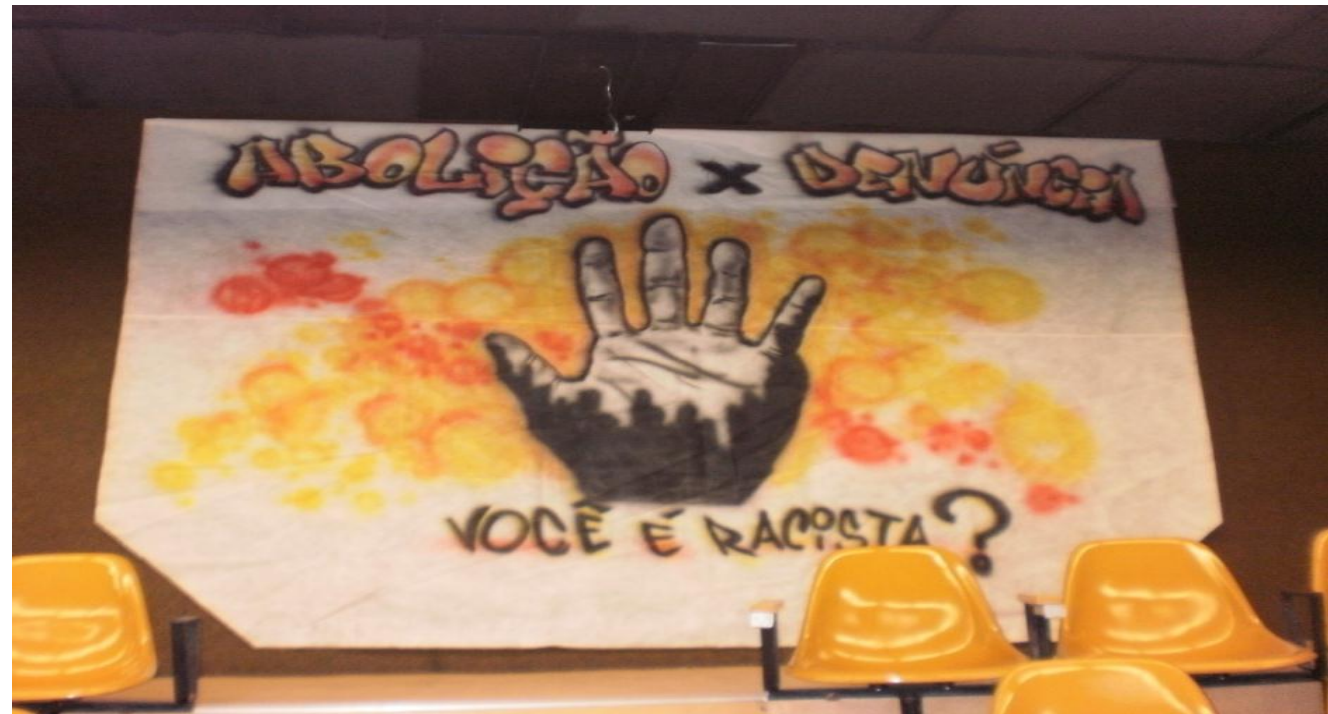

Foto 60 - Auditório do primeiro andar/fundos.

No fundo do auditório onde ocorreriam palestras e conferências com profissionais da rede publica de ensino e outros participantes de projetos a ela vinculados, tendo como temática central o racismo e a abordagem nas escolas, um banner de pano pintado com dizeres: "Abolição X Denúncia: você é racista?" ilustra e aponta o tom das discussões.
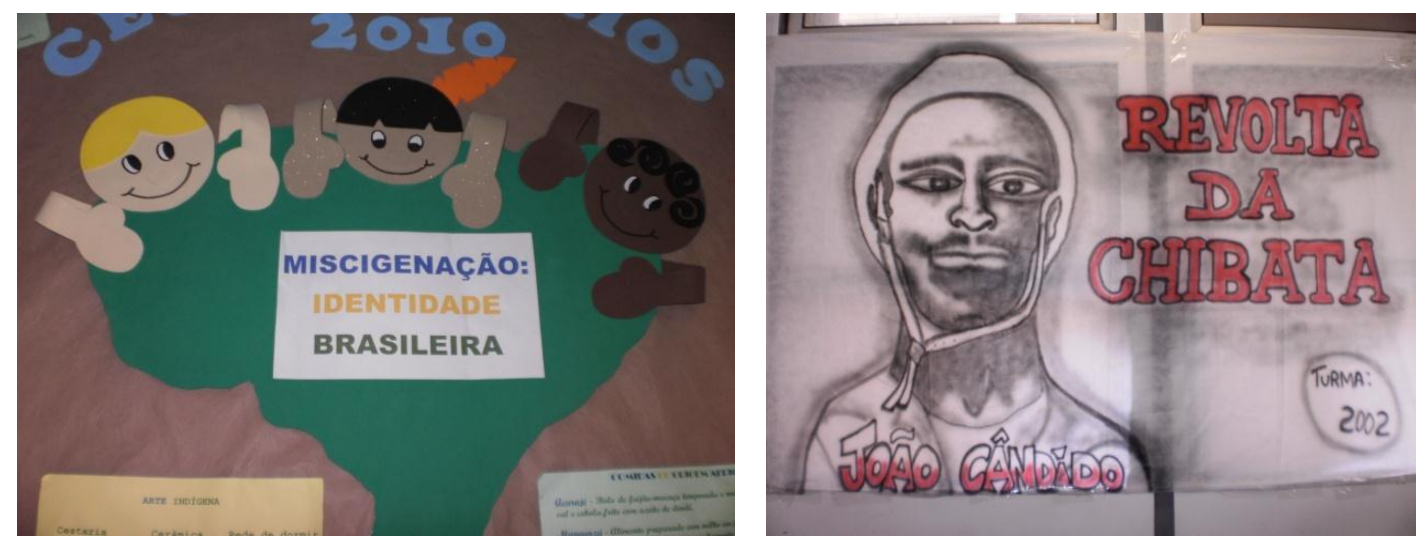

Fotos 61 e 62 - Fotos expostas nas paredes do terceiro andar, durante um evento sobre infância e racismo. Os autores dos cartazes são alunos de escolas municipais, CIEPs, estudantes do segundo grau da Universidade. 


\subsection{Segundo momento da pesquisa: a seleção das fotos}

Diante do grande contingente de cartazes, dizeres, pinturas e da grande rotatividade destas imagens, nem tudo é apreendido pelos que por ali passam. Vários elementos chamam a atenção por motivos mais gerais e particulares, ou seja, podem estar vinculados a um tema de maior repercussão no momento e por isso atrair a atenção de um grande número de passantes, como dizer respeito aos interesses de cada um, de forma particular. A correria do dia-a-dia contribui para que os sujeitos passem sem se darem conta de muitas das informações que ali circulam, o que explica a escolha de lugares tão inusitados de exposição. As paredes ficam invisíveis quando muitos de nós olhamos e não notamos.

O olhar do pesquisador é mais um na multidão. Entretanto, o critério que define o que será capturado e o que ficará de fora depende dos interesses e do senso estético dele próprio, agregados à busca na direção do objeto de pesquisa: "a política de cotas na UERJ nas suas mobilizações e práticas cotidianas".

Neste processo de registrar, com a captura das imagens ou com relatos, é com o "deixar de dentro" e escolher os elementos que ficam de fora, que se configura a então "política da narratividade".

Tomando a escritura do texto como fundamental tanto quanto as demais estratégias do ato de pesquisar sob a perspectiva da cartografia ${ }^{47}$, Kastrup e Barros (2010) enfatizam a importância em diferenciar a prática do relato de um registro de informações meramente burocrático.

Longe de ser um momento burocrático, sua elaboração requer até mesmo um certo recolhimento, cujo objetivo é possibilitar um retorno à experiência do campo, para que se possa então falar de dentro da experiência e não de fora, ou seja, sobre a experiência. Há uma processualidade na própria escrita. Um processo aparentemente individual ganha uma dimensão claramente coletiva quando o texto traz à cena falas e diálogos que emergem nas sessões ou visitas ao campo. (Kastrup e Barros, 2010, p.71)

Ainda sobre a prática dos relatos:

Ao escrever detalhes do campo, com impressões, paisagens e sensações, o coletivo se faz presente no processo de produção de um texto. Nesse ponto, não é mais um sujeito pesquisador a delimitar seu objeto. Sujeito e objeto se fazem juntos, emergem de um plano afetivo. (...) a pesquisa se faz no movimento, no acompanhamento de processos, que nos tocam, nos transformam e produzem mundos. (Kastrup e Barros, 2010, p.73)

\footnotetext{
${ }^{47}$ Os relatos aqui referidos compreendem tanto os feitos no formato de registro escrito, quanto imagético.
} 
Durante cinco meses são feitos registros das imagens em todos os andares e cantos da UERJ, em murais, nos bebedouros, nas portas dos banheiros, etc. Foi reunido um total de 600 fotos e feita uma análise posterior, que foi realizada tomando por base alguns critérios, listados a seguir: Interlocutor (destinatário, pra quem se fala); Conteúdo (temática e sub-temática); Atores (grupos, alunos cotistas e não cotistas, movimentos estudantis, grupos militantes, instituição, sindicato dos funcionários, reitoria, etc.).

O que fazer com as fotografias? Uma análise do material parecia pertinente, ao mesmo tempo insuficiente diante dos locais encontrados e dos efeitos possivelmente provocados nos interlocutores que por elas se deparam cotidianamente. Era preciso uma opção metodológica que colocasse os autores das imagens em contato com os seus interlocutores, para quem se destinavam os discursos. Sob esta perspectiva, colocam-se questões: "Quais seriam os principais destinos dos discursos ali expostos? Para quem as imagens se dirigiriam? Alunos? Professores? Instituição administrativa?".

Uma reflexão mais atenta do material determinaria as próximas diretrizes metodológicas. Para tanto, optou-se em colocar no diálogo outras vozes. Uma vez com a posse de aproximadamente 600 fotografias feitas durante o período semestral na UERJ, algumas decisões foram tomadas: (1) Descobrir os destinos, a origem e o conteúdo dos discursos/mensagens postas nas fotos. (2) selecionar dentre as 600 imagens, um grupo reduzido de fotografias que pudessem ser apresentadas a alguns destes atores sociais selecionados. A próxima etapa de pesquisa seria, então, deixar falar as vozes para quem se destinavam as imagens, mas no contato com as próprias imagens. Uma conversa a três: o remetente, o destinatário e o pesquisador.

Foram então selecionadas 41 fotos. O principal critério usado foi contemplar um número representativo e variado de interlocutores. Estes grupos deveriam ser aqueles que surgiram nas próprias fotografias.

Desta forma, foi feita uma seleção prévia pelo pesquisador, reduzindo o número total para 150 imagens. Essas 150 fotos foram apresentadas para o grupo de pesquisa que, numa discussão coletiva, ajudou a construir um conjunto de 44 fotos que contemplasse a pluralidade de atores que apareceram nas imagens.

Foram escolhidos 10 grupos principais a serem entrevistados e a maioria das fotos apontava o modo e os locais em que poderiam ser feitos os contatos com os possíveis entrevistados. As demais entrevistas seriam escolhidas a partir dos caminhos apontados nas próprias entrevistas, com a ajuda dos sujeitos da 
pesquisa. É importante reiterar que os entrevistados teriam que estar, de alguma forma, representados nas imagens, de modo a se reconhecerem como parte do acervo selecionado.

Optou-se por entrevistas em grupos e/ou individuais, sem um roteiro predeterminado. Aliás, melhor seria dizer que esse roteiro estava prédeterminado na medida em que as 44 fotos quando apresentadas para os entrevistados, seriam elas próprias as entrevistadoras. O roteiro das perguntas estava estampado nas "paredes" e as questões seriam as que este conteúdo impulsionado pela curiosidade e impressões do pesquisador - deflagraria a partir da relação entre "sujeitos da pesquisa" e os interlocutores das paredes.

\subsection{Terceiro momento da pesquisa: a busca pelas entrevistas}

Uma vez estabelecidos os grupos que seriam entrevistados, após análise do material de campo - fotos e relatos - sigo na busca de contatar os sujeitos para agendamento das entrevistas. É um período que exige grande disponibilidade do pesquisador tendo em vista que os horários precisam estar de acordo com a agenda dos sujeitos da pesquisa e não o contrário.

$\mathrm{Na}$ medida em que um ou outro contato vai sendo estabelecido, uma grande rede de indicações vai se formando. Um indica outro, que conhece outro e assim sucessivamente. As surpresas são muitas e é preciso também certa disponibilidade para percebê-las e permitir-se ser surpreendido.

Os estudantes dos cursos integrantes dos centros acadêmicos se mostram extremamente solícitos, de uma maneira geral. $\mathrm{O}$ engajamento nas temáticas que as imagens deflagram justifica o entusiasmo em falar sobre assuntos que fazem parte do cotidiano de reivindicações e militâncias dos estudantes, como: o funcionamento do bandejão, o passe-livre para os estudantes, a precarização do ensino público e sua democratização e a discussão racial.

O acesso às instâncias institucionais também é facilitado, neste caso, muito em razão do pesquisador ser simultaneamente professor da instituição.

Fica latente, contudo, a reivindicação de alguns participantes na relação com o pesquisador sobre os rumos possivelmente tomados pelo trabalho, após os depoimentos para a pesquisa. Recados e recomendações são feitos após a concessão das entrevistas no sentido de garantias de manutenção das informações em coerência com as posições assumidas pelos entrevistados, o que denota certa preocupação se os usos feitos pelo pesquisador de suas falas serão equivocados ou distorcidos. 
Os interesses em fazer uso da tese conferindo certo direcionamento ao trabalho aparecem em algumas falas, ao final das entrevistas, da mesma forma que uma devolução sob o formato de palestra ou no próprio trabalho marca a relação entre sujeitos da pesquisa e pesquisador, o que torna ainda mais delicados os rumos a serem tomados no momento de escritura do texto.

É preciso reflexão e análise do pesquisador frente às posições a serem assumidas não somente nas entrevistas, mas principalmente no ato de confecção do trabalho final.

A rede intercomunicante que possibilita o acesso aos sujeitos da pesquisa funciona como facilitadora deste acesso, ao mesmo tempo em que inclui o pesquisador na grande rede de relações entre os sujeitos, entremeados por negociações, jogos de poder e interesses. As reivindicações e os discursos convocam o pesquisador a tomar partido, posição e a questionar-se sobre as concessões que podem ou não ser feitas neste processo.

\section{7. É pessoal ou profissional? As intempéries de um andarilho- fotógrafo}

\subsection{1. "Sem nomes hein!"}

É o que diz uma ex-aluna do curso em que sou professora no momento em que nos preparamos para uma entrevista. A preocupação da jovem se apresenta no momento em que coloco o gravador na mesa e peço permissão para registrar a conversa. Garanto o anonimato da estudante e a tranquilizo, quando começamos finalmente a olhar as fotos.

Estamos no centro acadêmico do curso e, portanto, no espaço dos alunos de socialização, descanso, reuniões, estudos em grupo, bate-papo, etc. Ali eu era estrangeira na terra do outro. Muitos ali me conhecem, foram meus alunos. A receptividade é bastante amistosa embora as posições permaneçam bem delimitadas.

A entrevista que antes parece insossa, mais uma entrevista previamente organizada com perguntas bem definidas vai mudando de formato quando abro o documento no computador e aparecem as fotografias. As imagens aguçam a curiosidade dos estudantes. Alguns que não estavam na roda de conversa se aproximam curiosos para ver as fotos. "Onde é isso? Eu nunca vi?" exclama um jovem diante de um dos lugares exposto. 


\subsubsection{Outra entrevista...}

(Díárío de bordo) Entramos numa sala a partir da permissão de um segurança que nos libera a entrada digitando um código numa porta de vídro. Explico um pouco a proposta da entrevista. Pedi um computador onde pudessem ser expostas as fotos. Abrem-se as imagens no computador da própría sala. Uma das entrevistadas encarregou-se de passá-las.

O pesquisador, nesse momento, acumula duas funções: a de entrevistador e a de entrevistado. Entrevistador, quando interfere inevitavelmente na condução da entrevista. Entrevistado quando, a cada foto apresentada, embora já conhecida, se descortinam novos sentidos apontados pelos entrevistados e pelo próprio pesquisador, que revê sua posições, a todo momento, vendo nas fotos novos elementos.

As fotos que continham algo que tratasse das atividades do Projeto, naturalmente, chamavam especial atenção. As que continham imagens produziam efeitos diferentes das que continham textos escritos. Estes últimos demandavam certo tempo para leitura. Sentia certa ansiedade e, por alguns momentos, me percebo lendo os textos para os entrevistados de modo a agilizar o processo.

\subsection{3.“Essa não é a posição do Centro Acadêmico, mas a minha, pessoal."}

Esta frase foi mais de uma vez dita por estudantes dos vários grupos entrevistados. A preocupação em demarcar as posições pessoais e diferenciálas das vinculadas ao grupo chama a atenção, dando uma imagem de heterogeneidade aos movimentos que são interpretados, muitas vezes como, homogêneos quanto aos posicionamentos, interesses e modos de articulação. Ao que tudo indica, no momento em que um integrante passa a fazer parte de um grupo, seus discursos ganham repercussão de grupo, o que, dependendo do que for defendido poderia comprometer todo um movimento que é, antes de tudo, coletivo. O que pode ser atribuído como responsabilidade do grupo e o que recai apenas no integrante que dele faz parte? As posições de seus integrantes são as mesmas? Quais as motivações/interesses dos integrantes coincidentes de forma a possibilitar a vinculação a um grupo mais amplo e quais as dissonantes? Mais do que isso, de que modo conciliar os interesses pessoais 
dos coletivos quando da participação de um movimento militante em função de causas bem estabelecidas? É pessoal ou profissional?

\subsection{4. "Essas fotos são pra uso pessoal ou profissional?"}

Esta foi a indagação que me foi feita quando estava no hall do primeiro andar da universidade em posse da máquina fotográfica. Preparava-me para registrar uns informes no quadro de avisos quando sou interpelada por um funcionário da segurança da universidade que educadamente me faz a pergunta. Pega de surpresa, respondo que é pessoal e então ele me autoriza a continuar dizendo: "ah, tudo bem, desculpe incomodá-la".

\subsection{5. "Ah. Vou mostrar essa foto aqui, que é muito interessante!”}

Esse é o comentário que faço em vários entrevistas. A curiosidade e ansiedade em fazer os entrevistados falarem sobre as fotos que mais me despertavam interesse atravessa vários encontros. $O$ ato de transcrever 0 material faz notar essas repetições e convoca o pesquisador a refletir sobre as interferências que produz no processo e as tentativas de induzir o sujeito da pesquisa a corroborar suas premissas e pré-concepções. A escolha pelas imagens foi também marcada por uma relação de empatia em relação às fotos $e$ essa relação se reflete no processo das rodas de conversa quando todos, pesquisador, sujeitos da pesquisa e interlocutores das imagens, são postos em diálogo.

\subsubsection{Entrevista sobre o tema das cotas? Você poderia conversar com fulano que é especialista no assunto!" ou "não sei se te ajudei, não sou especialista no tema das cotas"}

A assertiva acima foi feita por alguns entrevistados quando anunciava o tema de pesquisa de meu interesse. A preocupação em falar de um lugar de verdade e a interpretação dos interesses da pesquisa e do pesquisador refletese no imaginário dos sujeitos que, muitas vezes, expressam uma compreensão de pesquisa científica nos moldes das que se propõem a buscar a verdade dos fatos. Além disso, a curiosidade em entender os motivos pelos quais o pesquisador teria interesse em ouvir seus discursos e o que ele, pesquisador, 
gostaria de saber, está de certa forma posto na fala dos entrevistados, a exemplo das afirmações em destaque.

Estas e outras questões surgem no processo das entrevistas e encaminham importantes discussões sobre as implicações do pesquisador na relação com o campo e as concepções de ciência que estão em jogo quando uma metodologia desta natureza se apresenta como opção investigativa. Partese do pressuposto de que pesquisador e pesquisado afetam-se mutuamente e estabelecem uma relação dialética no acontecimento da entrevista. Entende-se ainda que o ato da entrevista não se inicia quando se aciona o gravador, tampouco se encerra com o desligar do aparelho. Assim sendo, ficam as reflexões: quais são as negociações e confrontos entre os sujeitos - pesquisador e pesquisado - e, em que medida essas negociações fazem parte do processo enunciativo? Há como estabelecer uma separação bem demarcada entre estas "interferências" e o conteúdo que resulta destas relações/entrevistas?

Este capítulo traz dizer/mostrar e fazer refletir sobre as questões éticopolíticas de um pesquisador cuja proposta investigativa traz, como princípio basilar, a construção de um trajeto durante a própria caminhada. O formato e os modos de registro do texto são mais uma tentativa de deflagrar questões do que afirmar conclusões. Isso explica a existência de uma série de indagações feitas no decorrer dos relatos, junto às imagens como recortes de situações espaçadas.

As pistas deixadas pelo caminho e as postas no decorrer do texto encaminham reflexões sobre o tema, servindo de disparadores para uma análise mais aprofundada quando os discursos são confrontados no ato da entrevista, num diálogo entre imagens e seus interlocutores, sujeitos da pesquisa e pesquisador. Os discursos que surgem destes encontros: eis o objeto de análise do último capítulo.

\section{Modos de fazer/operar a politica de reserva de vagas na UERJ: as práticas cotidianas nas vozes dos interlocutores}

Este capítulo pretende analisar as práticas cotidianas atravessadas pela experiência da política de reserva de vagas na UERJ, desta vez, sob a perspectiva dos atores sociais da instituição. Para tanto, vale retomar algumas questões $^{48}$ :

\footnotetext{
${ }^{48}$ Estas questões já foram citadas no capítulo anterior.
} 
(1) Como a política de reserva de vagas é manejada no processo de sua implementação na UERJ? (2) O que o sistema faz mover no cotidiano da universidade? (3) O que a política de reserva de vagas na UERJ, enquanto dispositivo de uma rede de agenciamentos mais ampla, faz produzir? (4) Como se dá o processo dos fluxos cotidianos na universidade produzidos a partir do sistema de reserva de vagas? (5) Que questões e temáticas a experiência da política de reserva de vagas faz suscitar e como estas ressoam nas experiências nas demais instituições públicas brasileiras?

Estas questões serviram como ponto de partida para a terceira etapa da investigação: as entrevistas. Para compreender o modo como o recurso da entrevista foi utilizado, considerando que as etapas de pesquisa se complementam e se entrecruzam, faz-se necessário retomar a proposta metodológica, no seu processo de construção.

\subsection{A entrevista e a seleção das fotografias}

A escolha da fotografia como forma de registro de pesquisa decorreu, sobretudo, da peculiaridade do modo de comunicação entre os sujeitos na UERJ: por intermédio de cartazes, charges, desenhos, informes espalhados pelos corredores e paredes.

Conforme descrição feita no capítulo anterior, foi reunido um acervo de aproximadamente 600 imagens-fotográficas durante o período de cinco meses de investigação. Em seguida, estas fotografias foram analisadas segundo dois principais critérios: "autorias do discurso" e "conteúdos temáticos". O objetivo inicial era o de identificar os principais grupos de "atores sociais" ${ }^{49}$ envolvidos e/ou afetados, de alguma forma, pela experiência das cotas, seja de modo direto ou indiretamente.

Dentre os grupos que aparecem no acervo maior, considerou-se entre os mais expressivos e representativos, com base nos dados da pesquisa, os seguintes: os representantes dos estudantes dos cursos de graduação; os representantes dos servidores da UERJ; os responsáveis pela gestão da política de assistência estudantil da UERJ - o PROINICIAR; os professores/pesquisadores sobre o tema das ações afirmativas e temáticas 
afins; os estudantes ingressantes pela reserva de vagas e os ingressantes pelas vagas não-reservadas ${ }^{50}$.

A fim de conhecer as práticas cotidianas e o modo como os sujeitos são afetados e atravessados pela experiência da reserva de vagas na UERJ, esta etapa metodológica procurou por em contato os sujeitos da pesquisa com as imagens-fotográficas registradas na etapa subsequente. Era preciso garantir que os autores das imagens registradas nas fotos se sentissem representados no conjunto das imagens selecionadas para as entrevistas e entrassem também em contato com os cartazes, desenhos ou outros, produzidos pelos demais sujeitos.

A proposta pretendia, portanto, possibilitar um encontro entre os vários grupos, fazendo-os refletir sobre temáticas afins ao tema das cotas, deflagradas pelas imagens/cartazes que circulam na própria Universidade cujos conteúdos, em sua maioria, tinham os próprios entrevistados como autores.

A opção pela entrevista como método de investigação, aqui, não tem por base um roteiro pré-determinado e a finalidade de buscar informações objetivas sobre o tema. Sendo assim, é preciso esclarecer o que se entende por este dispositivo e de que forma teria sido apropriado, nesta pesquisa, como recurso metodológico.

A "entrevista", aqui, é entendida como um processo de comunicação que tem por base a perspectiva dialógica. Partindo deste princípio, em concordância com Jobim e Souza (1999), entende-se por entrevista: "um espaço de construção de sentidos ou de produção de linguagem entre sujeitos organizados socialmente a partir de um enquadramento relacional específico". Afirma a autora:

É com o olhar do outro que me comunico com meu interior. Tudo o que diz respeito a mim chega à minha consciência por meio da palavra do outro, com sua entonação valorativa e emocional. (Jobim e Souza, 1999: p.46)

Este modo de compreensão da linguagem alinha-se a uma concepção de consciência específica, diferente do entendimento de atividade mental que se estrutura no interior e que se expressa no exterior na forma de linguagem. Ao contrário, é no acontecimento da interação social que se organiza o pensamento. Portanto, "fora de sua objetivação, de sua realização num material determinado (o gesto, a palavra, o grito), a consciência é uma ficção". (Bakhtin, 2006, p.122) É desta maneira que Bakhtin (2006) atribui à inter-relação social o

\footnotetext{
${ }^{50}$ Vale salientar a hibridização destes grupos, tendo em vista que em cada um deles pertence a mais de um grupo ou dentro de um mesmo grupo, se distanciam dos demais integrantes em alguns aspectos divergentes, etc.
} 
lugar, por excelência, em que se constitui o pensamento, sendo este o seu produto.

A personalidade que se exprime, apreendida, por assim dizer, do interior, revelase um produto total da inter-relação social. A atividade mental do sujeito constitui, da mesma forma que a expressão exterior, um território social. Em consequência, todo o itinerário que leva da atividade mental ("o conteúdo a exprimir") à sua objetivação externa (a enunciação) situa-se completamente em território social. Quando a atividade mental se realiza sob a forma de enunciação, a orientação social à qual ela se submete adquire maior complexidade graças à exigência de adaptação ao contexto social imediato do ato de fala, e, acima de tudo, aos interlocutores concretos. (Bakhtin, 2006, p.121/122)

Spink (1999) conceitua 'produção de sentidos diferente de "uma atividade cognitiva intraindividual' e, mais ainda, de uma pura e simples reprodução de modelos predeterminados". Neste caso, "produzir sentidos" consiste, pois, em "uma prática social, dialógica, que implica a linguagem em uso". (p.42)

Linguagem seria, pois, por definição, uma 'prática social'. Explica Spink (1999) que: "a pessoa não existe isoladamente, pois os sentidos são construídos quando duas ou mais vozes se confrontam: quando a voz de um ouvinte (listener) responde à voz de um falante (speaker)". E complementa: "A compreensão dos sentidos é sempre um confronto entre inúmeras vozes". Então,

Um enunciado não surge, magicamente, do nada. Ele constitui uma unidade do ato de comunicação, um dos elos de uma corrente de outros enunciados, complexamente organizados. Em outras palavras, ao produzir um enunciado, o falante utiliza um sistema de linguagem e de enunciações preexistentes, posicionando-se em relação a ele. O que estamos propondo é que, no cotidiano o sentido decorre do uso que fazemos dos repertórios interpretativos de que dispomos. (Spink, 1999: p.47)

O dispositivo "entrevista" seria, portanto, um espaço de resignificação de papéis socialmente instituídos, na medida em que aqui, não se vê entrevistador e entrevistado em postos hierarquicamente estabelecidos de uma vez por todas, de forma fixa e imutável, mas como atores sociais, com suas histórias pessoais, inscritas por sua vez em contextos sócio-culturais particulares e que, ao longo da entrevista, estão sujeitos a negociarem seus lugares sociais. A partir do ato da entrevista, tanto entrevistador quanto entrevistado têm a possibilidade de atribuírem novos sentidos aos seus modos de ver e interpretar o mundo e, possivelmente, construírem novos posicionamentos frente à vida.

Através da interdiscursividade seria possível compreender a dimensão ideológica presente na linguagem e visibilizar os conflitos, os embates, 
posicionamentos e redes de forças, que permeiam as experiências cotidianas dos sujeitos. É Bakhtin (2006) quem nos inspira a buscar no ato discursivo, aqui tomado pelo termo interdiscursividade, o que se intitula por "ideologia do cotidiano", na qual, explica o autor, é preciso distinguir vários níveis, determinados pela escala social que serve para medir a atividade mental e a expressão, e pelas forças sociais em relação às quais eles devem diretamente orientar-se". (p. 124)

A perspectiva Bakhtiniana de linguagem, que entende a natureza do ato de enunciação como sendo eminentemente social, justifica a opção pelo uso da entrevista como recurso investigativo em função da sua dimensão dialógica, como possibilidade de fazer emergir o processo de interação social, tendo a palavra, assim como as entoações e os movimentos interiores, como resultado da experiência da expressão social externa. Bakhtin (2006) entende por "individualidade criadora (...) a expressão do núcleo central sólido e durável da orientação social do indivíduo". (p.125) E ainda afirma:

\footnotetext{
Aí situaremos as palavras, as entoações e os movimentos interiores que passaram com sucesso pela prova da expressão externa numa escala social mais ou menos ampla e adquiriram, por assim dizer, um grande polimento e lustro social, pelo efeito das reações e réplicas, pela rejeição ou apoio do auditório social. (p.125)
}

Um roteiro pré-estabelecido de perguntas objetivas e diretivas, estruturado pelo pesquisador, por tudo que foi dito, não seria condizente com a pretensão maior da pesquisa: conhecer as práticas cotidianas que se descortinam na UERJ a partir da política de reserva de vagas, os modos de operar e as estratégias criadas no enfrentamento dos impasses, divergências e contradições.

A estratégia metodológica de confrontar as imagens-fotográficas com os interlocutores da pesquisa baseou-se no pressuposto de que estas imagens poriam à mostra as práticas cotidianas, ainda mais considerando que os discursos ali presentes - e/ou imagens - foram produzidos, em maioria, pelos próprios "praticantes cotidianos" da Universidade. Isto posto, alguns questionamentos direcionam as entrevistas, estando entre eles: 1. O que os autores dos cartazes que foram fotografados queriam transmitir? 2. Que experiências e práticas estariam submersas naqueles discursos? 3. Como se daria a construção de sentidos dos sujeitos no confronto com os cartazes fotografados que nos/os remeteriam a questões que fazem parte dos seus percursos diários na universidade e fora dela? 
Seria necessária, então, a opção por um recurso metodológico que colocasse em diálogo: o pesquisador, o sujeito da pesquisa - neste caso os grupos mais representativos - e as próprias imagens-fotográficas. As palavras de Bakhtin (2006), sobre o "diálogo", num sentido mais amplo - "não apenas como a comunicação em voz alta, de pessoas colocadas face a face, mas toda comunicação verbal, de qualquer tipo que seja" - e sobre a função central da linguagem - como "comunicação" e não meramente "expressão"-, inspiram a escolha da proposta metodológica. Isto porque:

A verdadeira substância da língua não é constituída por um sistema abstrato de formas linguísticas nem pela enunciação monológica isolada, nem pelo ato psicofisiológico de sua produção, mas pelo fenômeno social da interação verbal, realizada através da enunciação ou das enunciações. (p.127)

Fazem emergir, portanto, são somente os discursos que reverberam no processo de comunicação propiciado pelo acontecimento da entrevista, mas também todos aqueles presentes na cadeia de enunciações cujos limites não se restringem à situação social imediata, embora só possam ser compreendidos se contextualizados e circunscritos no momento específico de sua produção.

\begin{abstract}
Qualquer enunciação, por mais significativa e completa que seja, constitui apenas uma fração de uma corrente de comunicação verbal ininterrupta (concernente à vida cotidiana, à literatura, ao conhecimento, à política, etc.). Mas essa comunicação verbal ininterrupta constitui, por sua vez, apenas um momento na evolução contínua, em todas as direções, de um grupo social determinado. (Bakhtin, 2006, p.128)
\end{abstract}

É por esse motivo que o autor define as "unidades reais da cadeia verbal", como "enunciações", de tal forma que o estudo das formas destas unidades implica em não separá-las do seu curso histórico, uma vez que,

\footnotetext{
Enquanto um todo, a enunciação só se realiza no curso da comunicação verbal, pois o todo é determinado pelos seus limites, que se configuram pelos pontos de contato de uma determinada enunciação com o meio extraverbal e verbal (isto é, outras enunciações) (p.129)
}

Os pressupostos de Bakhtin (2006) inspiram a presente proposta metodológica e os preceitos que embasam a escolha da entrevista segundo um formato menos tradicionalista. Vejamos de que forma:

Para que o encontro entre pesquisador, os cartazes-fotografados (nos seus autores e interlocutores) e os sujeitos da pesquisa fosse possível, era preciso escolher quais as fotografias, dentro do acervo mais amplo de imagens registradas, seriam apresentadas nas entrevistas. A seleção aconteceu da 
seguinte maneira: das 600 fotografias, foram selecionadas $150^{51}$, de modo a formar o conjunto final de 41 "imagens-fotográficas". Havia, portanto, um conjunto de questões para as entrevistas, não diretivo, tampouco estruturado. As fotografias comporiam um roteiro investigativo para as entrevistas. O modo como seria conduzido este roteiro dependeria do transcorrer de cada encontro.

A intenção maior seria a de promover um debate intra e intergrupos, mediado pelas imagens encontradas nas paredes da UERJ abrindo, ao mesmo tempo, um espaço para que os sujeitos expressassem suas convicções, opiniões, construindo sentidos próprios para suas experiências.

No cotidiano, uma pluralidade de atores se faz presente no manejo e nos modos de operar a política e a interdiscursividade produzida pelos atos de fala deflagrados pelas imagens-fotográficas descortina a "arena ideológica" que constitui o espaço acadêmico. Esta é a peculiaridade do contexto universitário: trata-se de uma grande rede de agenciamentos que se estende para os arredores de seus limites geográfico-espaciais.

É neste sentido que o debate sobre a política de reserva de vagas ganha as ruas e, ao mesmo tempo, o debate das ruas se reflete do lado de dentro dos muros da universidade. A definição de universidade de Duarte e Rampinelli (2005) se alinham à este pressuposto. Trata-se, pois, de:

Uma instituição social que exprime e reflete, de modo historicamente determinado, a sociedade em que está inserida. Ela configura e dá forma às relações sociais, mas também é configurada por elas, pelos embates políticos e pelas disputas acadêmicas que atravessam e determinam o lugar social em que existem. (p.21)

Vejamos de que forma as tensões e as redes de relações se configuram e se presentificam a partir do uso da entrevista como método de investigação.

\subsection{A entrevista propriamente dita: as imagens-fotográficas entrevistam}

As fotografias das imagens espalhadas pelos muros da UERJ diziam e mostravam. Alguns entrevistados funcionavam como espécies de "tradutores", "legendários", ao mesmo tempo em que conferiam sentidos novos para suas próprias ações.

\footnotetext{
${ }^{51}$ As 150 fotografias foram apresentadas aos pesquisadores do GIPs - Grupo Interdisciplinar de Pesquisa da Subjetividade e após uma ampla discussão foram selecionadas as 41 fotografias finais.
} 
O pesquisador exibe as 41 fotografias e explica a proposta da entrevista, solicitando que os sujeitos da pesquisa comentassem livremente sobre as imagens-fotográficas. As fotografias estavam organizadas segundo uma sequência específica e, a princípio, foram apresentadas segundo esta ordem. A escolha das imagens a serem comentadas era livre, assim como a opção em não comentar as que não despertassem maior interesse. ${ }^{52}$ Desta forma, cada grupo cria uma sequência de fotografias e um repertório próprios. Fica, então, a cargo do entrevistado, escolher as imagens que desejasse comentar, que mais Ihe despertasse interesse ou que lhe dissesse respeito de forma direta ou indiretamente.

O pesquisador, por sua vez, também participa da construção do "mosaico fotográfico" de cada grupo uma vez que, em alguns momentos, motivado por suas curiosidades, impressões e experiências prévias ${ }^{53}$, chama a atenção dos entrevistados para uma foto ou outra, convocando-os a analisá-las mais atentamente.

Em algumas entrevistas, é seguida a primeira ordem organizada das fotos. Mas as imagens escolhidas e comentadas não são as mesmas, diferem em uma ou outra entrevista. Em outras situações, a dinâmica do encontro subverte a ordem original das fotos, de tal maneira que o pesquisador começa a acompanhar os discursos em busca das imagens-fotográficas, que passam de entrevistadoras a desdobramentos dos discursos dos próprios sujeitos entrevistados. É neste momento que estes últimos - os sujeitos da pesquisa conduzem a entrevista e constroem narrativas próprias, conferindo aos interlocutores das imagens-fotográficas e ao pesquisador $o$ papel de coadjuvantes em lugar de protagonistas.

Chama a atenção quando certos discursos, disparados por algumas das imagens-fotográficas presentes no acervo final, se interconectam com temas presentes em fotografias que podem ser encontradas no acervo mais amplo de imagens coletadas. É neste instante que a referência aos "interlocutores" presentes nas imagens-fotográficas reflete os sentidos dados por Bakhtin (2006) para o "processo de fala" como:

\footnotetext{
52 De forma a facilitar uma análise posterior, foram numeradas as fotografias de 1 a 44 e dados títulos que procuravam associar os autores e o tema principal que as fotos suscitavam. Esta numeração e identificação foram feitas para fins de organização do material surgidos após as entrevistas e para melhor analise das respostas e das discussões deflagradas por intermédio destas imagens. Algumas fotografias ganharam titulo em função dos temas que mais apareceram nos discursos dos entrevistados quando estas imagens vinham á tona o que, de antemão já se começa a descortinar as categorias principais e as temáticas analisadas neste capítulo.

${ }^{53}$ Sobretudo as experiências relativas ao contato já antes estabelecido com o campo.
} 
A atividade de linguagem tanto exterior como interior (...). Este processo é ininterrupto, não tem começo nem fim. A enunciação realizada é como uma ilha emergindo de um oceano sem limites, o discurso interior. As dimensões e as formas desta ilha são determinadas pela situação da enunciação e por seu auditório. (p.129).

Constrói-se, então, uma narrativa própria de cada acontecimento da entrevista. As fotografias ganham, ao mesmo tempo, características e direcionamentos diferentes, marcando duas dimensões: uma de caráter universal, quando os conteúdos afetam quase todos os entrevistados; e, outra de caráter particular, na medida em que algumas fotos se referem às ações especificamente protagonizadas por alguns grupos sendo, portanto, abordadas de forma mais detida pelos próprios. Em poucas palavras, os atores sociais entrevistados se identificam com questões tanto numa perspectiva mais ampla, coletiva, quanto individual, de cunho particular ${ }^{54}$.

As identificações dos sujeitos aos grupos dos quais se afiliam, nas suas variâncias e hibridizações, refletem um entendimento de subjetividade que descarta a perspectiva individualista como eixo. É preferível, pois, considerar uma:

Concepção mais transversalista da subjetividade, que permeia responder ao mesmo tempo a suas amarrações territorializadas idiossincráticas (Territórios existenciais) e suas aberturas para sistemas de valor (Universos incorporais) com implicações sociais e culturais. (Guattari, 2006, p.14)

Das construções destas narrativas afloram, ainda, conflitos e embates intergrupais, na medida em que os grupos se veem, uns aos outros, representados no acervo. As imagens não deflagram apenas temáticas. Conduzem, sobretudo, a pistas sobre os modos de funcionamento e de relações entre os grupos e sobre a existência de uma grande rede imbricada à experiência da política de reserva de vagas, fazendo emergir as contradições, as alianças e as divergências. A interdiscursividade assume a função de fazer emergir a "ideologia do cotidiano", de que trata Bakhtin (2006), na medida em que:

A enunciação enquanto tal é um puro produto da interação social, quer se trate de um ato de fala determinado pela situação imediata ou pelo contexto mais amplo que constituiu o conjunto das condições de vida de uma determinada comunidade linguística. (Bakhtin, 2006, p.126)

\footnotetext{
${ }^{54}$ Algumas questões só dizem respeito aos estudantes cotistas, outras dizem respeito mais diretamente aos estudantes cotistas com recorte racial, outras abrangem ao mesmo tempo os dois grupos, etc.
} 
Serão apresentados, neste capítulo, os discursos deflagrados a partir da interlocução com as 41 imagens-fotográficas selecionadas. Pretende-se ainda trazer as temáticas que aparecem mais recorrentemente nas entrevistas e os modos como são abordadas e analisadas nas vozes dos entrevistados ${ }^{55}$.

Serão trazidas como reflexão juntos aos discursos dos entrevistados e dos interlocutores das imagens-fotográficas discussões de autores sobre os temas principais suscitados na investigação. O campo de pesquisa fez emergir discussões que põem em análise modos de ser/estar na cidade contemporânea, as relações entre os sujeitos no interior da universidade a partir dos efeitos produzidos pela implementação do sistema de reserva de vagas. Para encorpar as discussões alguns conceitos serão abordados, segundo perspectivas teóricas que se afiliam aos temas propostos. E na sequência, as principais categorias de análise selecionadas na interface com as teorias e reflexões.

\subsection{O que a política de reserva de vagas fez fazer: As práticas cotidianas nas vozes dos interlocutores.}

\subsubsection{A Política de Assistência Estudantil e os Modos de Operar}

A pesquisa põe em análise uma política em processo de consolidação e que, em função de seu pioneirismo e das controvérsias geradas pela complexidade própria do tema, convoca o corpo universitário a criar "estratégias" de gestão e de enfrentamento das problemáticas a ela concernentes ${ }^{56}$.

Como parte das medidas usadas como política de assistência para os estudantes ingressos pelo sistema de reserva de vagas se destacam a "bolsapermanência" e o "Kit-cotista".

A "bolsa permanência" consiste em uma verba mensal destinada a custear gastos com transporte, material didático e alimentação no valor de 300 reais. Para que o estudante seja contemplado com a bolsa é preciso que tenha situação socioeconômica compatível com as exigências previstas na legislação e

\footnotetext{
55 A seguir as 41 imagens-fotográficas serão apresentadas junto com os discursos mais deflagrados por essas fotos. AS 41 imagens foram numeradas e a elas foi dado um título correspondente ao tema principal ali existente.

${ }^{56} \mathrm{O}$ capítulo 2 faz um apanhado histórico da política de reserva de vagas nas três universidades pioneiras e da política na UERJ, especificamente. O programa Proiniciar surge como a principal estratégia institucional de amparo e suporte aos estudantes ingressos pelo sistema de "cotas" na Universidade. Ver nos anexos as principais legislações. Lei 4151/03; Lei 5346 11/12/2008; resolução 043/2004.
} 
que a bolsa seja renovada periodicamente, caso seja comprovada a condição de "carência" do estudante.

Em deliberação de $n^{\circ} 040 / 2007$, de acordo com alteração aprovada pelo CONSELHO DE ENSINO, PESQUISA E EXTENSAO e promulgação do reitor, à época, Nival Nunes de Almeida:

Fica alterado o Programa de Iniciação Acadêmica para aluno da Graduação da UERJ, preferencialmente aqueles que ingressarem por meio da Lei $n^{\circ} 4151 / 03$, que regulamenta o Sistema de Cotas. (...) Título I - Do Objetivo - art. $2^{\circ}$ - Apoiar o estudante prioritariamente nos dois primeiros períodos da UERJ de modo a garantir-Ihe a permanência na Universidade, com aproveitamento, até a conclusão do Curso, viabilizando a transformação da Lei num efetivo mecanismo de redução das desigualdades sociais.

No art. $3^{\circ}$ a deliberação dispõe que:

Ficam instituídas bolsas de iniciação acadêmica, destinadas aos alunos que ingressem sob o benefício da Lei $n^{\circ} 4151 / 03$, prioritariamente, durante o primeiro semestre letivo podendo ser renovada por mais de um semestre, em quantidade compatível com a destinação orçamentária e financeira do Estado para tal fim.

Como se verifica nos trechos em destaque, a "bolsa-permanência", vinculada ao Programa Proiniciar, conta com uma verba concedida pelo Governo Estadual que se destina exclusivamente aos estudantes ingressantes pelas reservas de vagas na UERJ ${ }^{57}$. Entretanto, vários impasses surgem em função dos modos de gerir este recurso ${ }^{58}$, na sua execução prática. As razões serão analisadas pelos sujeitos de pesquisa, nas entrevistas a partir do contato com as imagens-fotográficas. Vejamos Algumas das maiores problemáticas e questões sob as variadas perspectivas:

\footnotetext{
${ }^{57}$ Criação da política de reserva de vagas - lei $n^{\circ} 043 / 2004$. As outras que alteram e introduzem novas deliberações: lei 040/2007 - a citada acima - lei n4151/03; lei n5346 de 11/12/2008. Ver em anexos.

58 Antes de analisar os discursos e as contradições que se visibilizam nos discursos dos entrevistados, é preciso considerar alguns aspectos: 1. O termo "benefício" não está aqui sendo usado como uma concessão do estado, numa perspectiva assistencialista, em contraposição a um direito. A discussão sobre "benefício" X "direito" levanta questionamentos e merece atenção especial no que se refere ao debate sobre o tema. 2. Todo projeto que se faz pioneiro se constrói no cotidiano de sua implementação com acertos, dificuldades e avanços nas estratégias de enfrentamento. O que significa dizer que, não se trata de responsabilizar um ou outro grupo menos ainda apontar "algozes" para possíveis brechas e/ou entraves do sistema e sim marcar os modos como as práticas cotidianas têm sido atravessadas pela política e os manejos e táticas usadas no enfrentamento dos problemas suscitados. 3. Apresentar o modo como, no dia-a-dia, a política opera, nos seus avanços, ações e impasses, segundo a perspectiva dos sujeitos, não deslegitima a possível eficácia do sistema enquanto política de ação afirmativa. Apenas fornece subsídios reflexivos para o enfrentamento dos problemas e possíveis estratégias de gestão.
} 


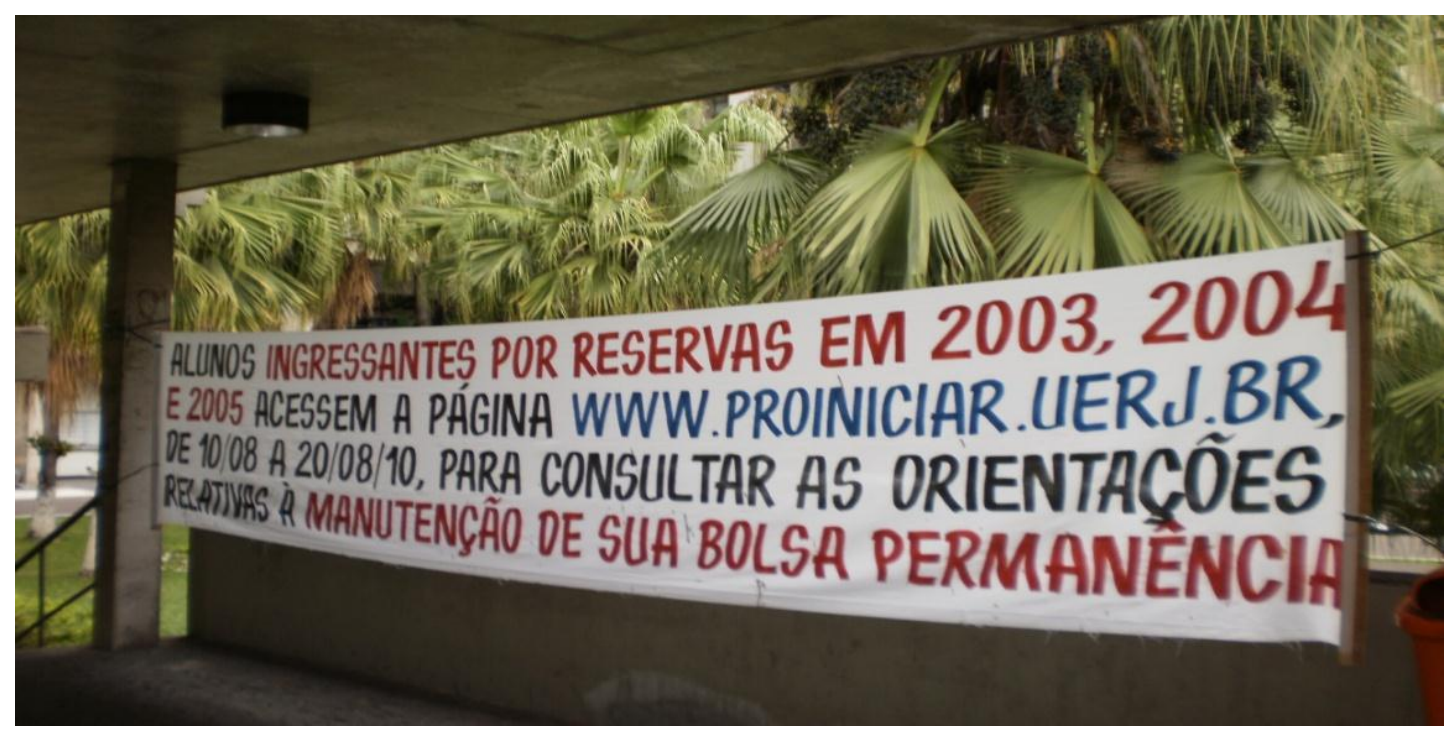

Foto 63 - "Proiniciar _banner: Orientações sobre manutenção da bolsa permanência"

A imagem acima refere-se a um banner exposto em um dos halls de entrada da universidade, com dados informativos sobre a manuntenção da bolsa do estudante ingressante pela reserva de vagas, nos seus procedimentos e critérios.

Ao depararem-se com a foto, em entrevista, integrantes do programa Proiniciar explicam o modo como se dá a manutenção da bolsa-permanência e os critérios que podem levar alguns estudantes à perda de sua condição de bolsistas. Segundo os relatos, parece não ocorrerem maiores problemas na manutenção do benefício, salvo em alguns casos específicos. É o que explicam alguns dos integrantes do projeto ${ }^{59}$ :

\begin{abstract}
A lei diz que a bolsa deve ser dada pro aluno que mantiver sua condição de carência. A gente percebeu que, em 2010, tínhamos muitos alunos recebendo bolsa em 2003, 2004, 2005. Já se passaram 7 anos. A gente sabe que tiveram algumas pessoas que precisaram trancar com problema de saúde, mas tem uma infinidade de problemas. Solicitamos a esses alunos, que estavam ainda cursando, que apresentassem a documentação pra confirmar a situação de carência. Por isso que eles são chamados. De vez em quando a gente faz isso: análise social, socioeconômica. Ou permanece com a bolsa ou não. Mas isso não dá muito problema. Acontece de um aluno ou outro perder o prazo. (funcionário)
\end{abstract}

\footnotetext{
${ }^{59}$ Como escolha metodológica, os discursos dos entrevistados serão identificados somente quanto às categorias: estudante, professor e funcionário. Por "E", entende-se "entrevistado". Somente as falas com mais de um entrevistado apresentarão a letra " $E$ " antes na respectiva fala. A numeração na frente da letra E, como E1, E2(...), foi escolhida de modo aleatório, somente para demarcar a existência de mais de um entrevistado em uma mesma entrevista. Por "P", entende-se "pesquisador".Mais uma vez opta-se por um fonte diferenciada em função das diferentes formas de registro presentes na pesquisa.
} 
O trecho explicita algumas medidas tomadas pela equipe do Proiniciar no manejo da política, uma vez que, frente a situações inusitadas, na medida do processo de implementação do programa, surge a necessidade de reconfigurações e de novas estratégias de atuação por parte da equipe.

O termo "estratégias" precisa de esclarecimentos. Tal elucidação decorre, sobretudo, da importância de sua distinção do termo "táticas", a ser usado em momento posterior neste texto. Certeau (1994) é quem analisa estes termos e nos fornece subsídios para refltir sobre as práticas cotidianas na universiade, especificamente sobre os modos de gestão dos sujeitos no que se refere à política de reserva de vagas da UERJ. Embora seja considerada Política de Estado, vários atores sociais entram em cena - as ações e protagonismos da sociedade civil organizada e seus efeitos nas políticas de ação afirmativa, analisados nos capítulos anteriores são um exemplo - e, somente em um esforço coletivo entremeado de embates e controvérsias de toda ordem, é que, de modo efetivo, a experiência ganha escopo e se estrutura.

As ações e práticas de gestão da política na UERJ contam, pois, com estratégias racionalizadas e estruturadas, para permanência e manutenção dos estudantes cotistas na instituição, mas ainda, além disso, com táticas dos vários atores sociais implicados com a mesma. O que distingue os conceitos de "táticas" do de "estratégias" é a natureza das ações. Explica Certeau (1994) o seguinte:

\begin{abstract}
Chamo de estratégia o cálculo (ou manipulação) das relações de forças que se torna possível a partir do momento em que um sujeito de querer e poder (uma empresa, um exército, uma cidade, uma instituição científica) pode ser isolado. (...) Como na administração de empresas, toda racionalização "estratégica" procura em primeiro lugar distinguir e um ambiente próprio, isto é, o lugar do poder e do querer próprios (...) as estratégias são portanto ações que, graças ao postulado de um lugar de poder ( a propriedade de um próprio), elaboram lugares teóricos (sistemas e discursos totalizantes), capazes de articular um conjunto de lugares físicos onde as forças se distribuem. Elas combinam esse três tipos de lugar e visam dominá-los uns com os outros. Privilegiam portanto as relações espaciais. (p.102)
\end{abstract}

Analisando as "estratégias" usadas para consolidação da política, retornemos à política de permanência e às ações institucionais voltadas para os estudantes ingressantes pela reserva de vagas. 


\section{A)O acúmulo de bolsas}

Uma das temáticas vinculadas à concessão da "bolsa-permanência" e geradora de divergências é a reinvindicação pelo "acúmulo de bolsas" para os estudantes "cotistas". As polêmicas decorrem de uma das regras estabelecidas como condição para que o estudante, ingressante pelo sistema de reserva de vagas, permaneça com o direito de manutenção da bolsa-permanência. Ficaria vedado a este estudante acumular qualquer tipo de bolsa-auxílio sob a penalização de perder a bolsa administrada pelo Proiniciar.

\section{INFORMATIVO PARA ALUNOS INGRESSANTES POR RESERVAS DE} VAGAS

Todo aluno oriundo do sistema de cotas tem direito a bolsa permanência. A bolsa vigora durante todo o curso universitário do estudante cotista que mantiver a condição de carente em cumprimento da lei 5346, sancionada em 11 de dezembro de 2008. A bolsa permanencia possui o mesmo valor das demais modalidades de bolsas internas da UERJ sendo atualmente de 300,00 (trezentos) mensais. Critérios para manuntenção da bolsa permanência: aluno ativo inscrito em disciplinas; aluno efetivamente cursando, ciente do comprometimento de frequência, ou seja, sem trancamento proveniente de reprovação por frequência em todas as matérias inscritas no período; aluno que se mantenha na condição de carente; aluno que não tenha outra bolsa interna; aluno que não deixe de atender a comprovações comprobatórias de carência feitas a qualquer tempo, previstas em lei e a cargo do Proiniciar; aluno com conta corrente aberta ao Banco Bradesco. ${ }^{60}$ (Rio de Janeiro, março de 2012) ${ }^{61}$.

O contingente de imagens-fotográficas abordando a discussão sobre o acúmulo de bolsas encontrado na pesquisa e a frequência com que o tema é trazido nas eleições para representação estudantil em vários espaços da universidade, sinalizam a grande mobilização gerada em torno do tema. As fotos abaixo foram comentadas por quase todos os entrevistados, especialmente pelos estudantes, cotistas e não-cotistas.

\footnotetext{
${ }^{61}$ No próprio informativo, são elencadas legislações pertinentes à política de reserva de vagas e à Política de Assistência Estudantil, quais sejam: lei 5346/08; AEDA 065/09; AEDA027/99 e 032/08; AEDA 088/11; Lei 5566/11.
} 

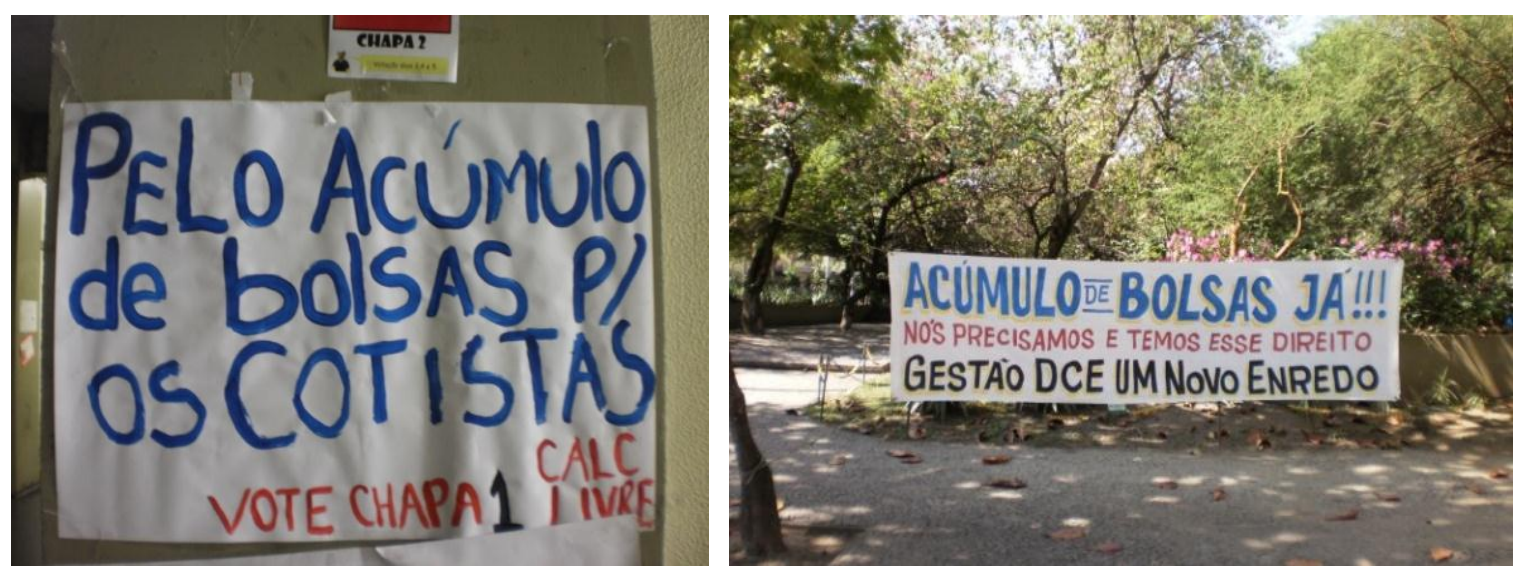

Foto 64 "Eleições CALC_acúmulo de bolsas para cotistas" e Foto 65 "Banner_ DCE/gestão 'um novo enredo': Pelo Acúmulo de bolsas” respectivamente.

As opiniões foram variadas. Um dos estudantes alega que a medida significaria um "fator-desmotivador" para os estudantes "não-cotistas". Este estudante teria se sentido injustiçado por entender como concessão de privilégios a bolsa-auxílio para os estudantes "cotistas" e a possibilidade do acúmulo com outras bolsas. Abaixo seu discurso:

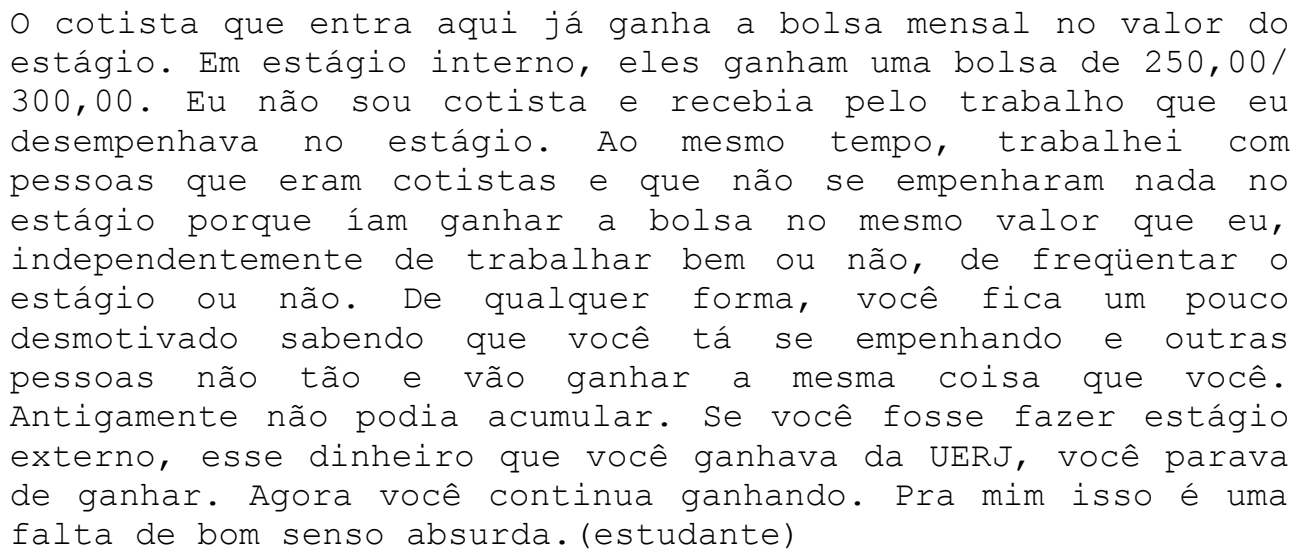

O discurso em destaque faz emergir a discussão que opõe as concepções de "benefício" e "direito" associadas às ações afirmativas, em discussão no capítulo 2. Neste momento, ficam em evidência os efeitos deste debate para as relações entre os estudantes cotistas e não-cotistas no dia-a-dia da experiência da política, sobretudo no que se referem ao tratamento e ações voltados para um e outro estudante.

No período compreendido entre o registro fotográfico dos cartazes e a apresentação das imagens-fotográficas aos entrevistados, ocorreram campanhas em prol do acúmulo de bolsas, desencadeando várias discussões. 
Um dos motivos de descontentamentos por parte de alguns estudantes seria o critério impeditivo para a manutenção da bolsa-permanência: a aquisição de outra bolsa de mesma fonte-pagadora que a anterior. Isto significaria que as bolsas de estágio interno e/ou as bolsas de iniciação científica financiadas pela UERJ, não poderiam ser recebidas pelo estudante-cotista, simultaneamente. Em função disto, o estudante que ingressasse em um estágio de pesquisa interno à UERJ ou em algum outro projeto que tivesse vínculo com a universidade, não poderia ganhar a bolsa de pesquisa, a não ser que abrisse-mão da bolsapermanência vinculada ao projeto Proiniciar. Em contrapartida, o estudante "cotista" que fizesse um estágio externo, em alguma empresa ou em local externo à UERJ, teria garantidas ambas as bolsas.

Os estudantes de cursos que buscam, em sua maioria, estágios em grupos de pesquisa na universidade foram, ao que tudo indica, os que mais se sentiram prejudicados com os critérios para manutenção da bolsa-permanência. Uma das queixas foi a possível falta de incentivo à alunos-pesquisadores em detrimento de alunos-trabalhadores. Abaixo, diferentes pontos de vista sobre o assunto:

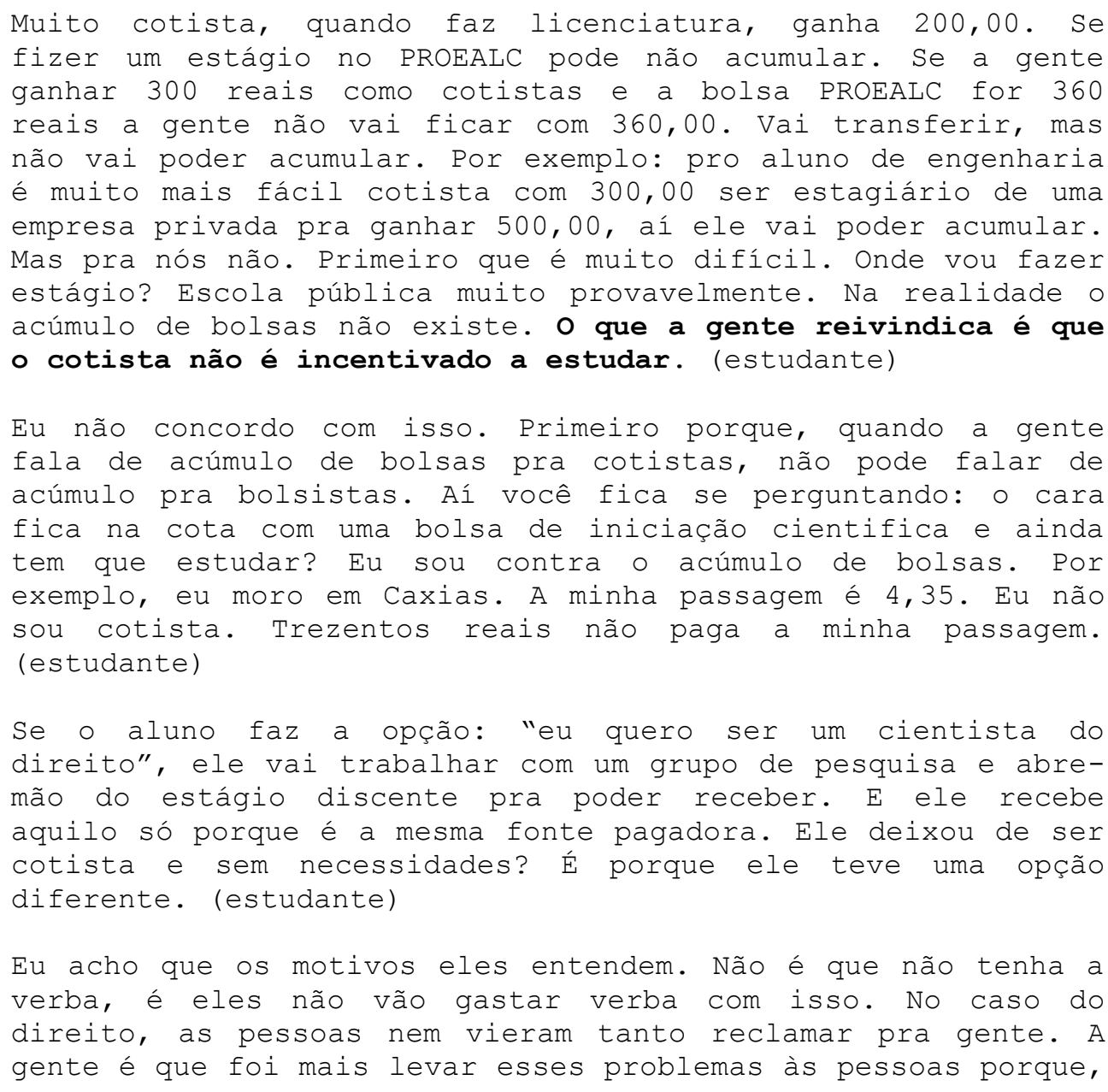


em geral, as pessoas fazem estágio externo, não é a mesma coisa de ciências sociais, de filosofia. (estudante)

O dilema frente o "suposto" não incentivo ao estágio interno, especialmente o atrelado à pesquisa, e o incentivo ao externo, comumente vinculado a empresas, instituições privadas, dentre outros, por razão da impossibilidade de acumulo de bolsas, coloca em cheque a função da universidade e a relação desta instituição com a lógica de mercado capitalista e suas demandas. As palavras de Chauí (2000) nos convocam a reflexão:

\begin{abstract}
Negar que a universidade adestre mão-de-obra é não perceber o significado preciso desse adestramento: a difusão e expansão do ensino médio, encarregado inicialmente dessa tarefa, por ter sido acompanhada da ampliação do ensino superior, devida a razões políticas, muito mais do que econômicas, levou a transferir para a universidade uma parcela das atribuições do ciclo médio profissionalizante, pois os empregados passam a fazer exigências maiores aos candidatos a empregos, não em decorrência de uma necessidade real de instrução avançada, mas simplesmente em virtude da disponibilidade de diplomados. Assim, por bem ou por mal, a universidade está encarregada de um treinamento genérico e prévio que será completo e especializado pelas empresas. (p.09)
\end{abstract}

Os comentários de alguns estudantes-entrevistados sinalizam que algumas medidas de assistência estudantil acabam por privilegiar experiências de estágio em empresas externas à universidade, sobretudo de estudantes provenientes de algumas áreas de formação em detrimento de outras. A hierarquia entre os cursos e áreas de conhecimento, que se reflete na própria relação candidato-vaga no processo seletivo do vestibular, ressurge através de uma política de assistência estudantil para estudantes ingressantes pelo sistema de reserva de vagas, cujos critérios tornam as condições destes estudantes desiguais no que se refere ao percurso acadêmico. Há que se considerar que as oportunidades para estágios e trabalhos, tanto no que diz respeito ao numero de vagas oferecidas, quanto no que se refere às remunerações, são distintas para estudantes de cursos de maior prestígio social, mesmo anterior à implementação da política de reserva de vagas nesta instituição.

No entanto, a UERJ não possuía uma política de assistência estudantil, que passa a ser constituída com o advento da política de reserva de vagas, trazendo á tona as problemáticas e as configurações do cenário desigual da educação brasileira de forma mais explícita. A polêmica do acumulo de bolsas serve como um dos disparadores para visibilizar estas questões.

Chauí (2000) analisa a reforma universitária feita a partir de 1968, pondo em destaque dois aspectos. Quando ao segundo deles, a autora afirma: "torna- 
se visível que a educação passou a ser um negócio do Ministério do Planejamento, muito mais do que um assunto do Ministério de Educação e Cultura". Vejamos como Chauí (2000) argumenta posteriormente:

Se, outrora, a escola foi o lugar privilegiado para a reprodução da estrutura de classes, das relações de poder e da ideologia dominante, e se, na concepção liberal, a escola superior se distinguia das demais por ser um bem cultural das elites dirigentes, hoje, com a reforma do ensino, a educação é encarada como adestramento de mão-de-obra para o mercado. Concebida como capital é um investimento e, portanto, deve gerar lucro social. (...) Desvinculando educação e saber, a reforma da universidade revela que sua tarefa não é produzir e transmitir a cultura (dominante ou não, pouco importa), mas treinar os indivíduos a fim de que sejam produtivos para quem for contratá-los. A universidade adestra mão-deobra e fornece força-de-trabalho. (p.07)

Outro tema motivo de embates e conflitos entre os grupos, mais especificamente entre os representantes dos cursos de graduação, refere-se à gestão do "Kit/cotista", um material destinado aos estudantes oriundos da reserva de vagas, também parte de uma política de permanência e vinculado ao Proiniciar ${ }^{62}$.

As problemáticas são muitas, sobretudo em função do circuito de compra e distribuição dos materiais, que começa no repasse da verba à universidade até a própria distribuição para os "alunos-cotistas". As dificuldades envolvem desde a escolha dos materiais (em muitos casos os estudantes participam desta escolha, representados pelos gestores dos CAs, considerando as necessidades e demandas de cada área de formação), passando pelo envio da verba pelo Estado ao órgão responsável pela compra, até as estratégias usadas nos modos de distribuição do material aos alunos. Esta última etapa do circuito - a distribuição aos alunos - causa divergências entre os CAs e os funcionários, na medida em que não fica estabelecido, de modo universal, a cargo de quem ficaria a responsabilidade pela tarefa.

O que fica visível é que, no circuito que envolve Estado - Proiniciar - CAs ou secretarias - "estudantes-cotistas", surgem problemáticas tanto macro quanto microestruturais que obstaculizam as ações e geram tensões entre os grupos envolvidos. Em suma, a execução da política de assistência estudantil envolve vários atores sociais, formando uma grande rede de relações entremeada por embates em diferentes instâncias.

\footnotetext{
62 Conforme já esclarecido, se trata de um material que conta com uma verba destinada exclusivamente para este fim, destinada aos estudantes de todos os cursos de graduação, exclusivamente os ingressantes pela reserva de vagas.
} 
Neste sentido, entre os fatores geradores de maiores conflitos estão as ações referentes à escolha e à distribuição dos materiais. Analisemos as duas etapas separadamente:

\section{B)A escolha dos materiais}

As imagens a seguir mostram que os materiais escolhidos diferem em cada área

de formação:

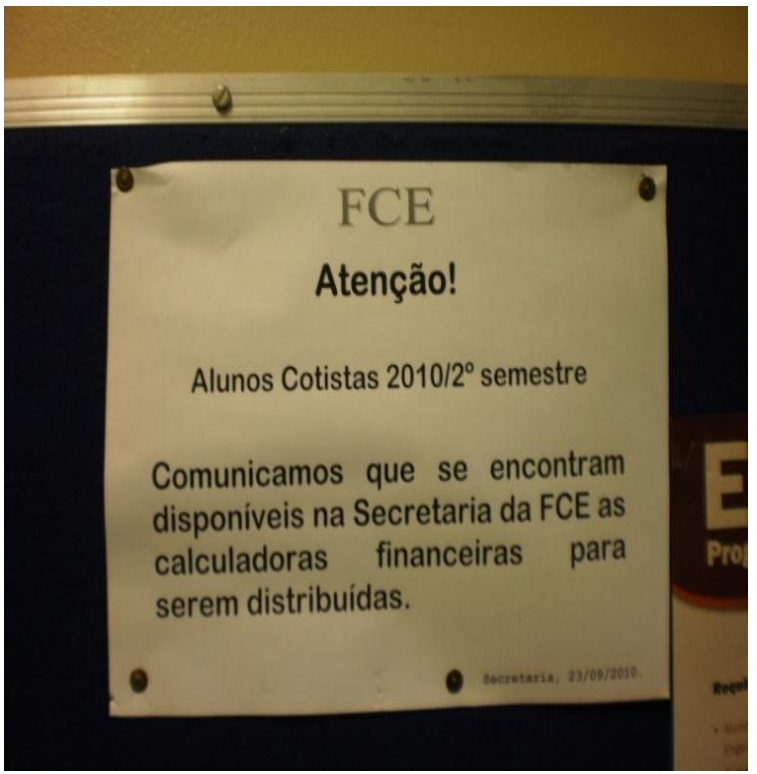

Foto 66 - Kit_cotista ciências econômicas

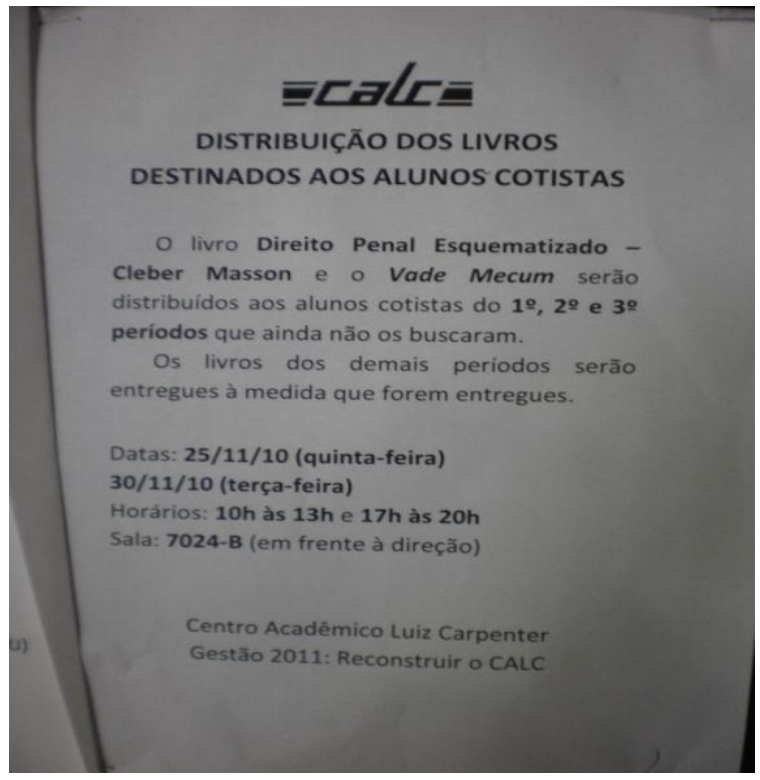

Foto 67 - Kit_cotista direito

Na primeira fotografia verifica-se que a distribuição do material aos alunos cotistas do curso de ciências econômicas fica a cargo da secretaria, ao passo que a distribuição do material do curso de direito ficaria sob a responsabilidade dos estudantes/representantes do próprio curso.

São várias as dificuldades encontradas em razão destas escolhas. Uma delas decorre das divergências entre as propostas políticas de gestão em relação à escolha dos materiais mais apropriados. Em alguns casos, na medida em que um novo grupo de estudantes assume uma nova gestão do CA de seu curso, são alterados os materiais escolhidos para composição do Kit/cotista, entre livros e outros. A outra questão decorreria do critério de participação dos alunos nesta tarefa, uma vez que fica atrelada à filosofia e aos modos de gestão de cada grupo, na medida em que assumem a representação dos estudantes de seu curso de formação. Em alguns cursos, somente os estudantes-cotistas participam das escolhas destes "kits". Em outros, todos os estudantes do curso, 
independente de serem ou não contemplados pela política, decidem em assembleia, coletivamente, os critérios usados na seleção destes materiais.

A participação dos grupos de representantes estudantis dos diferentes cursos no processo de manejo da política de permanência voltada para o "estudante-cotista" fica sobressalente quando os discursos dos entrevistados sinalizam os diferentes direcionamentos e estratégias de ação, relacionados aos distintos modos de gestão de cada grupo. A compreensão de "gestão" em Foucault (1979) nos faz refletir sobre estas práticas e seus efeitos, distanciando de uma visão que associa gestão e governabilidade e a uma prática estritamente legislativa, como atribuição exclusiva do poder instituído, sob a forma de imposição de leis e regras irrefutáveis. Vendo de outro modo:

(...) no caso da teoria do governo não se trata de impor uma lei aos homens, mas de dispor as coisas, isto é, utilizar mais táticas do que leis, ou utilizar ao máximo as leis como táticas. Fazer, por vários meios com que determinados fins possam ser atingidos. Isto assinala uma ruptura importante: enquanto a finalidade da soberania é ela mesma, e seus instrumentos têm a forma de lei, a finalidade do governo está nas coisas que ele dirige e os instrumentos do governo, em vez de serem constituídos por leis, são táticas diversas. (p.294)

\section{C) A Distribuição dos Materiais}

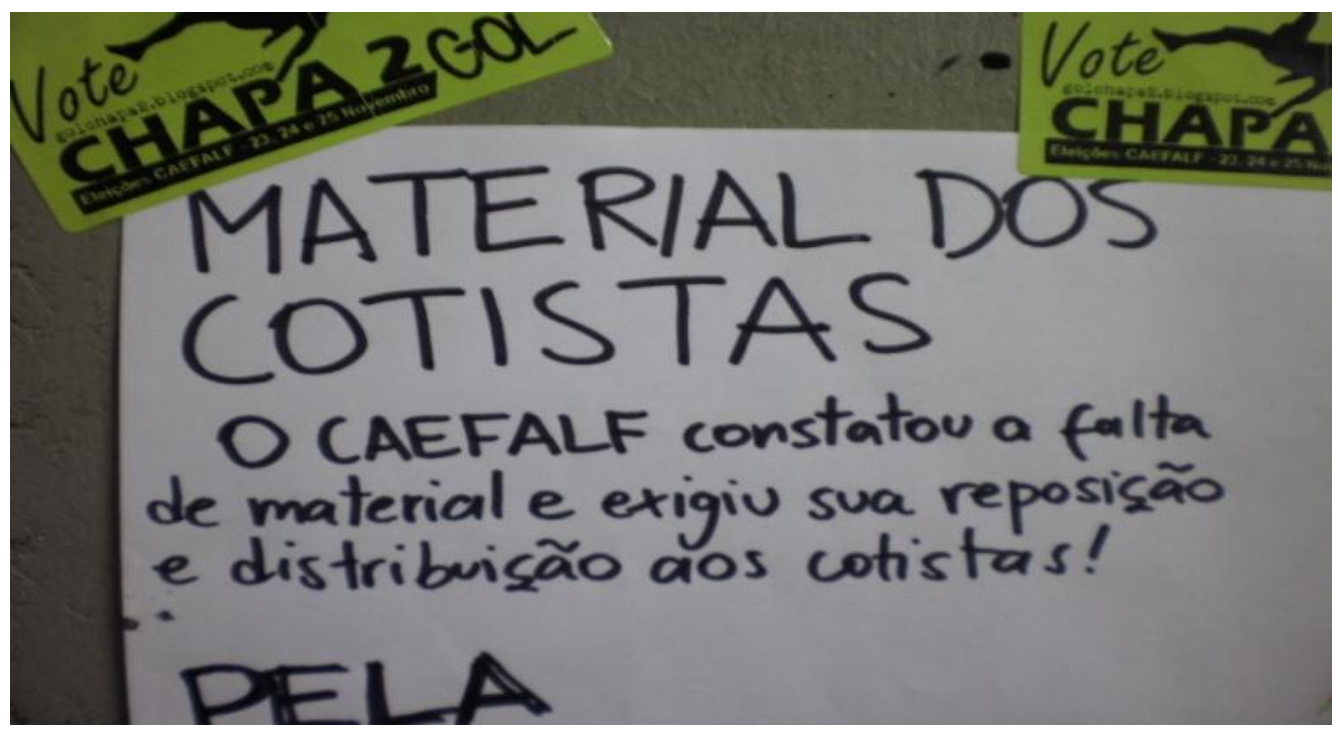

Foto 68 - "Eleições CAEFALF_distribuição do material dos cotistas"

Este cartaz fez parte do acervo de fotos tiradas durante o processo eleitoral para gestão de um dos centros acadêmicos dos estudantes. A questão referente à distribuição dos materiais aos estudantes é motivo de outra série de problemas envolvendo os grupos, em razão do repasse de verba do governo 
para a instituição; do repasse dos materiais da instituição aos centros acadêmicos ou às secretarias; do repasse dos materiais destes últimos aos "estudantes-cotistas".

Tendo em vista que um dos critérios de seleção das imagens-fotográficas foi o da "autoria dos discursos", na tentativa de contemplar uma pluralidade de grupos envolvidos na trama acadêmica, a exibição das imagens nas entrevistas coloca cada um dos grupos e cada sujeito em contato com os demais. Isso fez emergir uma grande arena de embates entremeada por falatórios e boatos de todos os tipos tratando do manejo da política e de suas brechas no processo de gestão, especialmente da política de assistência estudantil na instituição. Vejamos como um grupo de representantes de certo curso de graduação explica como percebe o processo:

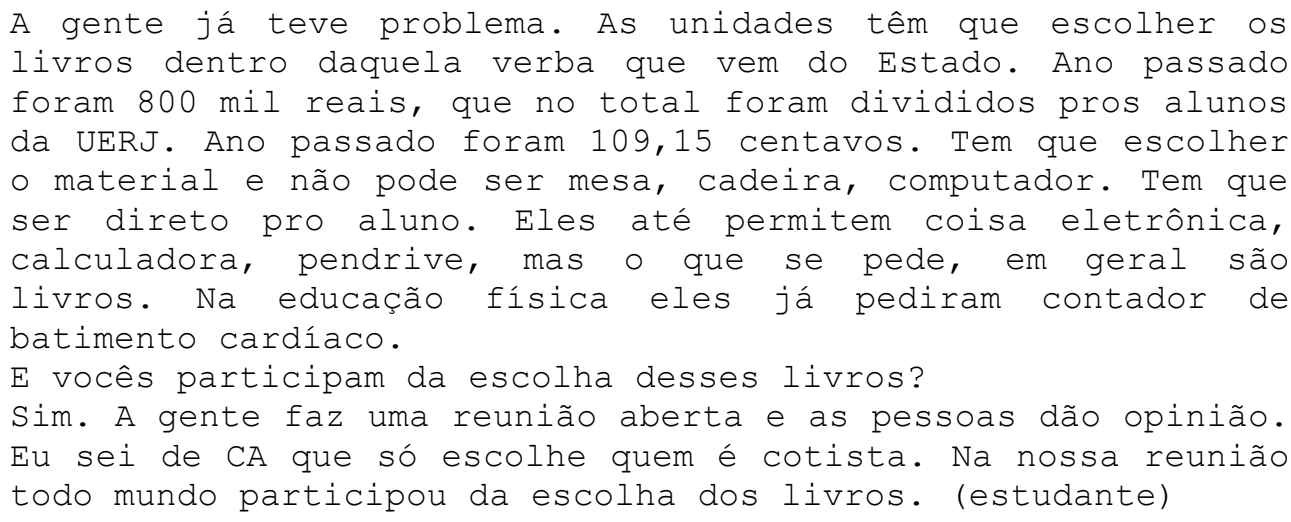

As tensões, próprias de um contexto atravessado por disputas de forças e jogos de poder, se visibilizam na medida em que a gestão da política de reserva de vagas implica em práticas coletivas e ações envolvendo os vários grupos em diferentes instâncias. É o que indica o discurso de um dos integrantes do Proiniciar:

A preocupação da gente quando se iniciou a política de cotas (e essa nossa percepção está sendo confirmada) era de que academicamente a universidade iria poder lidar bem com esses alunos, através de suas estratégias de reforço, do PROINICIAR, das próprias unidades. A grande preocupação era exatamente a questão financeira. E aí, através de duas leis de interlocuções com próprio governo, conseguiu-se a bolsa permanência, que é ao longo do curso todo, e uma verba anual que varia pra compra de material. O aluno decide junto com sua unidade o que ele acha que é prioridade pra comprar naquele ano e a gente só serve de intermediador, pede pro setor de compra, avisa que chegou e dá pras unidades. (funcionários do Proiniciar)

E continuam... 


\begin{abstract}
Na verdade é um pouco da unidade. Só fazemos a mediação. A gente recolhe os pedidos das unidades, passa pro setor de compra. O setor de compra faz cotação, compra e quando chega eles passam pra gente. O setor de compras entrega na unidade e a unidade é responsável, com os CAs, por convocar esses alunos e fazer a distribuição do material, que a gente tem que participar porque essa leva não vem separada por unidade. Vem uma verba inteira pra UERJ e é pactuada. Num primeiro momento a gente precisou pactuar, sentar todos os centros, todas as unidades e pensar: como vamos fazer? Vai ser por alunos. (funcionário do Proiniciar)
\end{abstract}

Outro participante do projeto complementa:

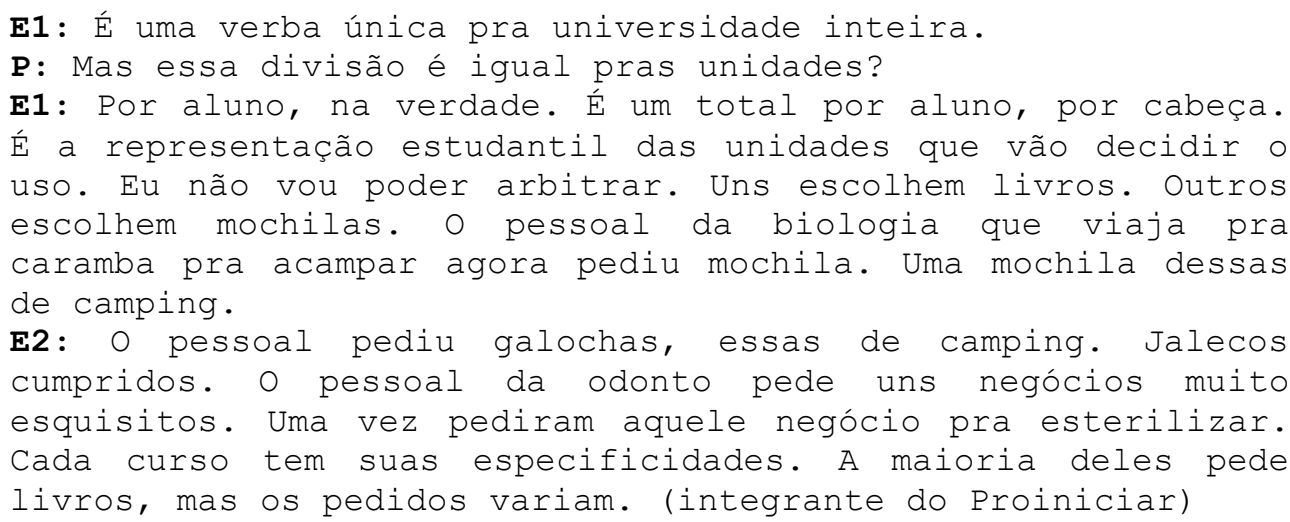

Analisando os processos de gestão da política de reserva de vagas, verifica-se que cotidianamente a execução deste projeto implica na ação de vários grupos, tanto de instâncias macro quanto microestruturais.

As posições assumidas pelos estudantes que representam os centros acadêmicos são diferentes. A co-existência de estudantes contemplados e de não- contemplados pela política nos grupos militantes promove, sob certos aspectos, uma cisão intragrupos. Estas posições, híbridas, por sua vez, mesclam-se à de co-gestores institucionais da política, quando sobre eles recai a tarefa de distribuição de materiais para "estudantes cotistas". Estas constatações nos levam a reflexões.

Sobre o ato de governar, Foucault (1979) menciona uma pluralidade de formas, que não confere, exclusivamente, o papel de governante ao Estado. A esse respeito - da "arte de governar" - o autor, fazendo referência a uma pluralidade de práticas situadas em posições variadas, diz:

No texto de La Perriére (...) a definição do governo não se refere de modo algum ao território. Governam-se coisas. Mas o que significa esta expressão? Não creio que se trate de opor coisas a homens, mas de mostrar que aquilo a que o governo se refere é não um território e sim um conjunto de homens e coisas. Estas coisas, de que o governo deve se encarregar, são os homens, mas em suas relações com 
coisas que são as riquezas, os recursos, os meios de subsistências, o território em suas fronteiras, com suas qualidades, clima, seca, fertilidade, etc. os homens em suas relações com outras coisas que são os costumes, os hábitos, as formas de agir ou de pensar, etc."

E continua...

O que é governar um navio? É certamente se ocupar dos marinheiros, da nau e da carga; governar um navio é prestar atenção aos ventos, aos recifes, às tempestades, às intempéries, etc. são estes relacionamentos que caracterizam o governo de um navio. Governar uma casa, uma família, não é essencialmente ter por fim salvar as propriedades da família; é ter como objetivo os indivíduos que compõem a família, suas riquezas e propriedades; é prestar atenção aos acontecimentos possíveis, às mortes, aos nascimentos, às alianças com outras famílias (...). O essencial é portanto este conjunto de coisas e homens; o território e a propriedade são apenas variáveis. (p.282/283)

As práticas de gestão do sistema de reserva de vagas não implicam somente na implementação de um contingente de vagas reservadas no processo seletivo do vestibular. A representação estudantil dos estudantes, junto aos CAs dos seus cursos, implica em uma mudança de posição de certos estudantes que, beneficiados ou não, passam a co-gestores no processo, interferindo nas decisões sobre as escolhas dos materiais e intermediando as relações entre os que gerenciam a política oficialmente e os estudantes, gestores "oficiosos".

A configuração da proposta na sua estrutura e organização, que inclui os parâmetros oficiais de funcionamento, legislação e regras institucionais, critérios bem delimitados - estratégias - esbarra nas nuances e intempéries próprias dos modos de gestão da proposta no dia-a-dia dos fluxos e práticas cotidianas nas universidades.

Surgem, então, as brechas do sistema cujas razões se devem tanto no caráter experimental de uma proposta que se consolida gradativamente, quanto e principalmente, dos entraves impostos pela própria falibilidade da estrutura da universidade, nas peculiaridades inerentes ao cenário da instituição pública brasileira. Um caminho possível que se descortina para a solução de uma das perguntas iniciais: "o que o sistema de reserva de vagas fez fazer no cotidiano da universidade?" dar visibilidade a um contexto de conflitos, tensões e entraves cotidianos em função das dificuldades de um sistema educacional público precário. Situemos o debate a partir dos relatos dos sujeitos envolvidos. 
D) As brechas do sistema, os embates e as táticas:

A verba é muito pequena e o grande problema é que esse
material não costuma chegar. Não é que não costuma chegar,
aqui chega os do ano passado. Eles chegam com muito atraso e
não chegam todos. Do ano passado, que era outra gestão, acho
que eles pediram quatro livros diferentes. Seria um livro pra
todos os perídos pra completar verba e um pra cada dessas
faixas. A gente opta. E só chegaram dois livros. (estudante)

Quando a gente passou pra eles, ainda tinha aproximadamente 60. Tinha um livro de desenvolvimento motor que é caríssimo. Custa de 80 a 150 reais. Ta lá. E eles não estão entregando. Tem um prazo e depois desse prazo, se a galera não for lá pegar, se eles quiserem sortear ou distribuir entre eles, eles vão distribuir. (estudante)

A gente escolheu um livro voltado pra licenciatura e outro voltado pro bacharelado. O do bacharelado não chegou. O da licenciatura chegou. Ano passado nós pegamos um livro de licenciatura e um material relacionado ao bacharelado. Hoje tá tudo abandonado. O material tá lá, perdido. Eles não demonstram nenhum interesse pra pegar nesse ano de eleição. Como centro acadêmico na época, sempre pegamos pra fazer. Teve falta de material. Chegaram na educação física, na direção, 30 polares. Chegou 80 depois 30 . E aí daria 110 polares. Mas, vamos supor, 120 pessoas. Uma quantidade maior de cotistas em relação à quantidade de polares que chegou. E - diretor da unidade falou na minha cara que era pra gente não divulgar no mural que o material dos cotistas tinha chegado, porque as pessoas iam esquecendo e não íam pegar esse material. A gente: "negativo! É deles e a gente tem que entregar pra eles!". A gente começou a bater de frente, puxou uma assembleia, uma comissão pra ir até a direção contar quantos materiais tinham, contar a relação que eles tinham de pessoas que assinaram e retiraram aqueles materiais e comparar com a relação que a gente pegou lá embaixo. A direção nem sabia que a gente tinha isso em nossas mãos. (estudante)

As falas em destaque mostram a existência de um "jogo de empurra" entre as instâncias que participam da gestão da política de permanência. Repasse de verba, utilização do material previsto como direito dos estudantes cotistas como mote de campanha eleitoral, tanto da parte dos estudantes candidatos as gestões dos CAs quanto da própria instituição. O que se analisa, para além dos relatos, são as práticas cotidianas que fazem operar o sistema de reserva de vagas, nos bastidores da instituição e que refletem o fosso existente entre a idealização de um projeto e sua implementação da prática.

As discussões precedentes ressoam nas ponderações de Certeau (1995) sobre o conceito de cultura, diferente de um "tesouro a ser protegido dos danos 
do tempo ou um conjunto de valores a serem defendidos", mas, antes, "um trabalho a ser realizado em toda extensão da vida social". É neste sentido que o autor defende a substituição de "uma 'cultura no singular, que impõe sempre a lei de um poder', por uma concepção centrada na 'cultura do plural', que conclama incessantemente pelo combate". (Certeau, 1995, p.11)

As tensões entre os atores que participam da gestão da política na prática de sua consolidação no cotidiano atravessam as divergências nos modos de gestão de cada grupo, os entraves macroestruturais que obstaculizam o processo e convoca os envolvidos a criarem táticas de enfrentamento de forma a tornar viável o sistema. É como se verifica na fala a seguir:

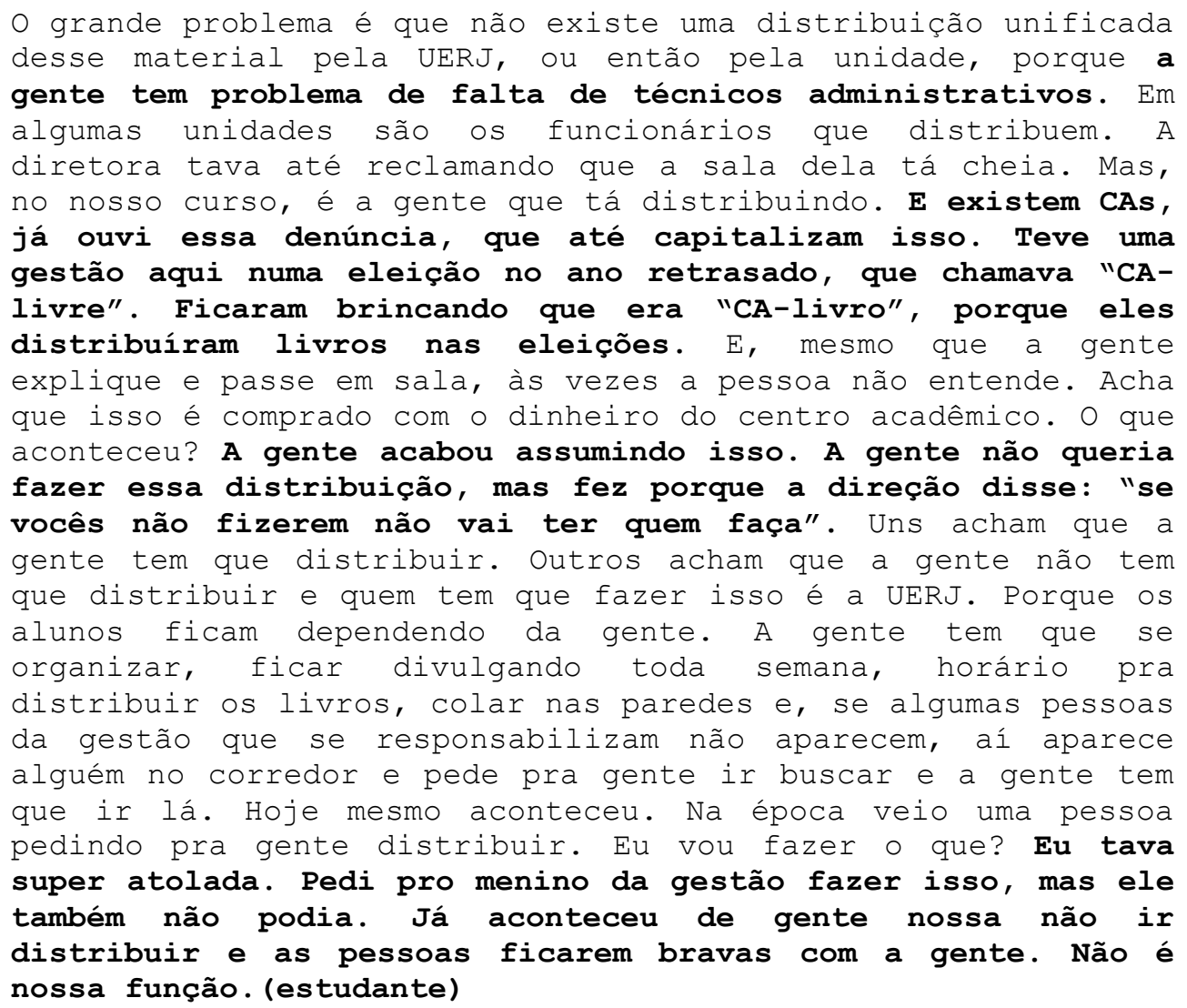

As passagens descritas nos levam a reflexões sobre a "concepção de poder" proposta por Foucault, na medida em que:

Suas análises não consideram o poder como uma realidade que possua uma natureza, uma essência que ele procuraria definir por suas características universais. Não existe algo unitário e global chamado poder, mas unicamente formas díspares, heterogêneas, em constante transformação. O poder não é um objeto natural, uma coisa; é uma prática social, e como tal, constituída historicamente. (p.X) 
Ao utilizar a expressão "microfísica do poder", Foucault propõe analisar a questão do poder a partir de:

Um descolamento do espaço, tanto da análise quanto do nível em que este se efetua. (...) os poderes periféricos e moleculares não foram confiscados e absorvidos pelo aparelho do Estado. Não são necessariamente criados pelo estado, se nasceram fora dele, foram inevitavelmente reduzidos a uma forma ou manifestação do aparelho central. Os poderes se exercem em níveis variados e em pontos diferentes da rede social e neste complexo os micro-poderes existem integrados ou não ao Estado. (p.XII).

Quanto à universidade, retomemos as análises de Chauí (2000) a respeito de sua fragmentação, pós anos 68 que, segundo a autora, se deu em vários níveis, "tanto nos cargos administrativos quanto nos de direção". (p.10)

O taylorismo é regra. Isso significa, em primeiro lugar, que a fragmentação não é casual ou irracional, mas deliberada, pois obedece ao princípio da empresa capitalista moderna: separar para controlar. (...) a imposição deliberada de uma vida cultural fragmentada, fundada na radical separação entre decisão e execução, conduz a uma unificação bastante precisa: a da administração burocrática. O que caracteriza a burocracia é a hierarquia funcional de postos e cargos, que, por sua vez, determina uma hierarquia de salários e de autoridade, um sistema de poder no qual cada um sabe quem comanda diretamente e a quem comanda diretamente, sem que seja possível uma visão do conjunto e a determinação de responsabilidades. Por seu turno, a administração, forma contemporânea da racionalidade capitalista, implica a total exterioridade entre as atividades universitárias de ensino e pesquisa e sua direção ou controle. (p.10)

As análises precedentes encaminham direções a respeito de algumas das questões inaugurais deste capítulo: (1) Como a política de reserva de vagas é manejada no processo de sua implementação na UERJ? (2) O que o sistema faz mover no cotidiano da universidade? (3) O que a política de reserva de vagas na UERJ, enquanto dispositivo de uma rede de agenciamentos mais ampla, faz produzir? (4) Como se dá o processo dos fluxos cotidianos na universidade produzidos a partir do sistema de reserva de vagas?

A política de reserva de vagas faz deflagrar fluxos cotidianos e ações entremeadas por conflitos e controvérsias de toda ordem, na medida em que a gestão da política envolve diferentes grupos e sujeitos com diferentes pontos de vista e implicações distintas.

Retomemos, além destas, uma última questão: Que questões e temáticas a experiência da política de reserva de vagas faz suscitar e como estas ressoam das experiências nas demais instituições públicas brasileiras? Com a vez: o debate sobre a política de cotas nas vozes dos interlocutores da pesquisa. 


\subsubsection{O Debate sobre a Política de Cotas: Os Sujeitos da Pesquisa na Interface com As Imagens}

Dentre as imagens-fotográficas apresentadas nas entrevistas, algumas fizeram emergir o debate sobre as cotas, causando grande repercussão e permeando a maior parte dos discursos dos entrevistados.

Algumas fotos, de conteúdo mais diretivo, colocam em cena, problemáticas que permeiam os debates extramuros da universidade. $O$ debate sobre as cotas no Brasil e seus aspectos principais ${ }^{63}$, nos convoca a algumas reflexões que merecem ser retomadas: 1 . Seriam promovidos atualmente espaços de debates em torno do tema na UERJ e, em caso afirmativo, haveria expressiva adesão e participação da comunidade nestes eventos? 2. Ainda prevalece a divisão entre os favoráveis ou contrários à política, mesmo após aproximadamente 10 anos de sua implementação na universidade? 3. As controvérsias geradas pelo uso do critério racial para reserva de vagas ainda permanecem? Neste caso, como os atores sociais manejam as divergências e convivem com as mesmas levando em consideração a concretização da experiência e a coexistência de estudantes cotistas e não-cotistas na instituição?

As entrevistas, mediadas pelas imagens-fotográficas, tornam-se pequenos "fóruns de debate". As mesmas fotografias suscitam respostas variadas, fazendo deflagrar as discussões que estão postas nos textos acadêmicos, nos jornais de maior circulação e nos bate-papos por toda a cidade, sobretudo na ocasião da implementação da política nas principais universidades do país.

A seguir, serão apresentadas algumas das imagens-fotográficas utilizadas nas entrevistas que abordam o tema do debate sobre as cotas, especificamente, e os discursos e questões por elas deflagrados.

\footnotetext{
${ }^{63}$ Apresentado no capítulo 2.
} 


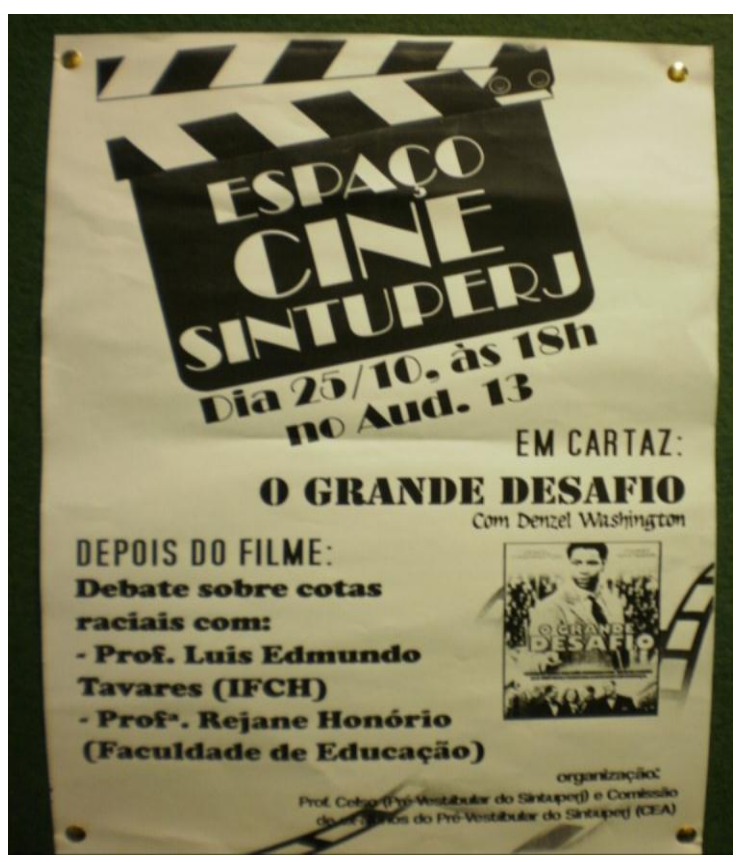

Foto 69 - "O Grande Desafio": Debate sobre cotas raciais.

Ao que tudo indica, a ausência de um debate mais profícuo envolvendo a sociedade civil mais ampla permanece como "queixa" e a falta de consenso sobre o tema continua provocando tensões e animosidades.

O cartaz anuncia um evento promovido pelo Sintuperj datado de 25/10/2011. As informações indicam a exibição de um filme - O Grande Desafio - com debate sobre as cotas raciais, contando com a presença de professores na função de debatedores e mediadores.

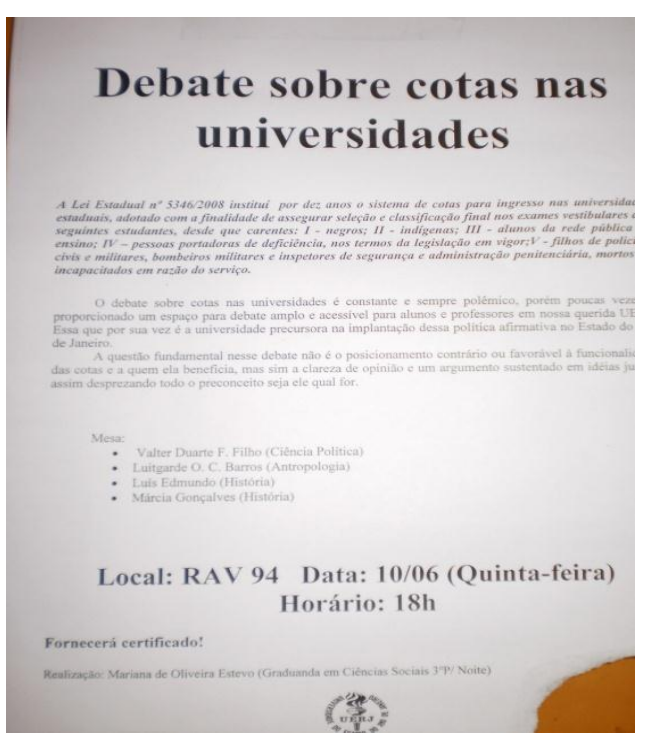

Foto 70 - Debate sobre cotas na universidade 
Este outro cartaz também convoca para um debate sobre a política de cotas, com data prevista para 10/06/2011. Este, por sua vez, foi organizado por uma aluna do curso de ciências sociais, com a presença de acadêmicos e pesquisadores.

Nas entrevistas, de frente com estas duas imagens-fotográficas apresentadas, os discursos sinalizam certo desconhecimento sobre debates desta natureza na universidade. Alguns atribuíram tal desinformação à falta de uma divulgação adequada. Outros comentaram sobre a pouca frequência com que esses debates ocorrem na UERJ, e a baixa participação da comunidade da UERJ nos eventos, ressaltando a necessidade de mais encontros sobre o tema das ações afirmativas.

Alguns relatos apontaram certo clima de tensão e animosidade nestes eventos. Vejamos o comentário de um dos entrevistados, referindo-se ao debate como "bate-boca":

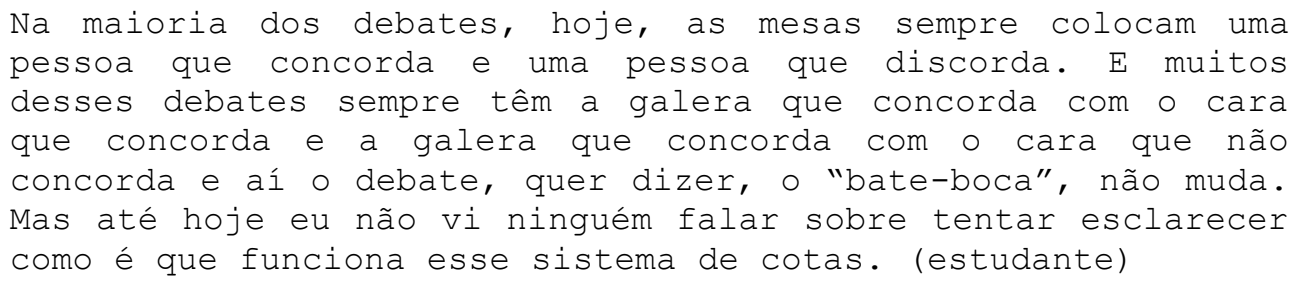

Foi enfatizada a necessidade de haver mais espaços de discussões e de veiculação de informações mais contundentes sobre o tema. Muitos entendem os posicionamentos assumidos nestes encontros como equivocados, em função da desinformação sobre o que, de fato, consiste a política de reserva de vagas, nos seus históricos, fundamentos e pressupostos e sobre os modos de implementação da política, quanto aos critérios e práticas de gestão do sistema.

\footnotetext{
Acho muito interessante o Sintuperj fazer um debate sobre as cotas raciais na UERJ, onde 50\% mais ou menos dos alunos vem de cotas e onde não tem debate disso. Mesmo porque, o antigo DCE não fazia debates sobre gênero, entradas de estudantes negros, indígenas ou brancos que vêm de escola pública, independente da raça, cor. (estudante)

P: Você ficou sabendo desse debate?

$\mathbf{E}$ : Aqui as coisas são muito boicotadas. Você tem um cartaz de uma coisa que não interessa as pessoas que, entre aspas, acham que cuidam da universidade e mandam os funcionários tirarem mesmo. Embora seja importante e eu acho que tem que ter discussões sobre isso na universidade, ainda mais aqui (aqui é que deveria ter), aqui parece o lugar onde menos as pessoas demonstram interesse. E quando tem as pessoas não têm
} 
interesse porque a universidade, hoje, ainda tá mudando. Eles sempre vêm com aqueles jargões: "diferenciar cor, reforçar ainda mais o preconceito". Mas eles não se reportam a nada do 'porque'. Não citam nem as questões sociais e nem o passado lá na época da escravidão, raciocinando criticamente sobre o processo de evolução histórico pra entender esse sistema. Tem muita gente que ás vezes fala do sistema e nem sabe como é que o sistema funciona. (estudante)

E: 10 anos! Viu o que eu te falei? É a lei que implementa essas cotas e diz mais ou menos como é que elas têm que ser. Pega fogo! Não é muito divulgado. Geralmente você não fica sabendo, mas pega fogo a discussão, quando entra o negro. A maioria das pessoas aqui é a favor de cota social e não da cota racial. E aí entra a discussão. E começa um falando daqui, outro falando de lá e não chega a lugar nenhum.

P: Nesses debates têm gente que fala contra as cotas?

E: Não. Falam contra a cota racial. Contra a cota não. Nos outros centros acadêmicos, medicina, odonto, lá rola coisa assim, contra, porque você não vai acompanhar o curso, etc. (estudante)

Eu acho que, hoje, quase todo mundo é a favor de cota. Diferente de quando você tá no ensino médio, aqui é tido mais como natural, comum. Têm algumas pessoas que eu acho que são contra racial, mas eu acho que não se faz muito o debate. Já se tem como estabelecido. (estudante)

Participar de debates, eu acho que poucos. Mas se você perguntar, acho que até por um constrangimento social, as pessoas são quase todas a favor das cotas. (funcionário)

\subsubsection{A) "Políticas de ação afirmativa", "política de cotas" ou "política de reserva de vagas"?}

As controvérsias sobre o tema partem, antes de tudo, dos termos mais ou menos apropriados para referir-se a política. Alguns dos entrevistados discutem sobre o termo mais correto, especialmente entre as expressões "ação afirmativa" e "políticas de cotas".

E1: "Políticas afirmativas!"

E2: Ele ta falando que não é pra falar cotas. Eu falo políticas afirmativas.

E3: Cotas não. Nós acadêmicos temos que falar políticas de ação afirmativa.

P: É porque, dentro das políticas de ação afirmativas, têm várias políticas, dentre elas as cotas.

E2: Na verdade, a política de cotas é a política de reserva de vagas.

E3: Viu? Já me corrigiu que tava errado.

E2: Aí depende. As pessoas que trabalham com isso conceituam de maneira diferente. (estudantes)

E: A política é de ação afirmativa. Têm várias outras formas, tem bônus, tem pontuação, até porque o termo cotas é aplicado 


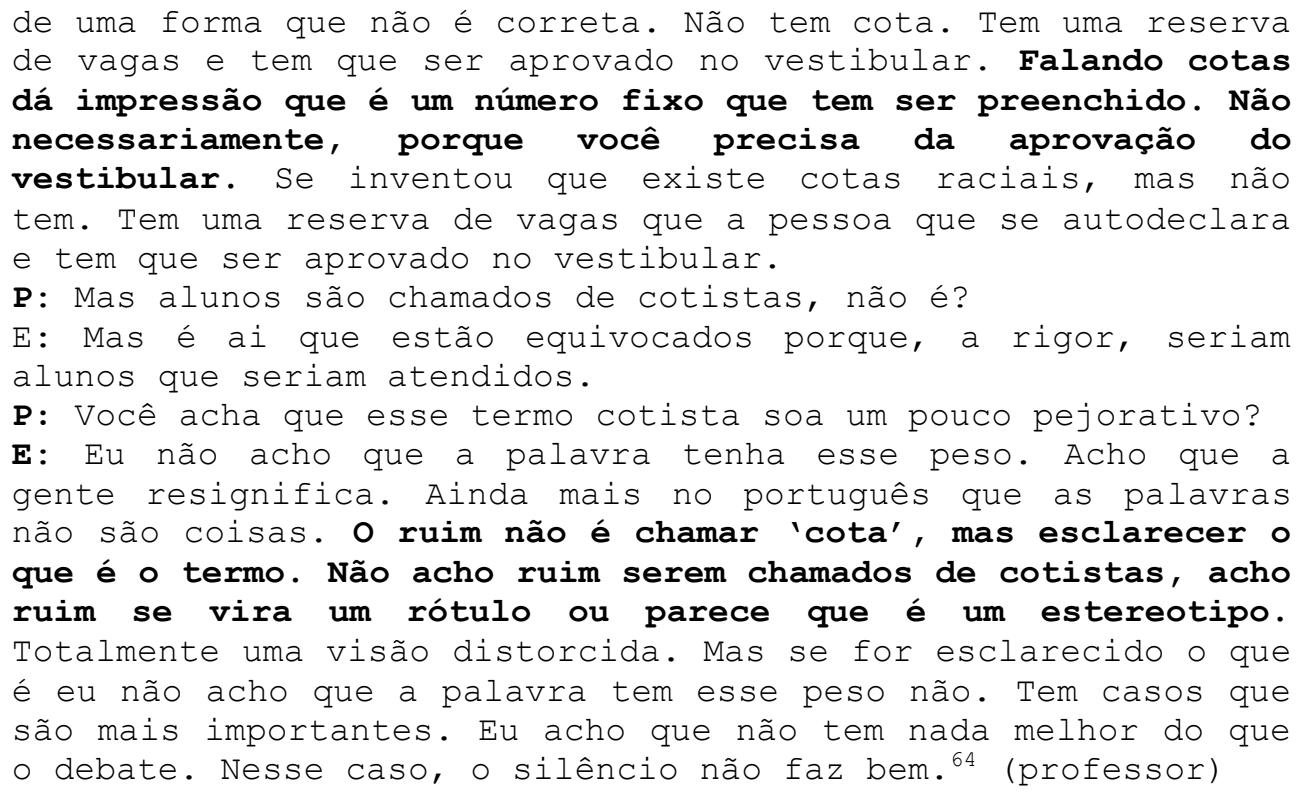

A necessidade de estabelecer os termos mais ou menos apropriados para referenciar a política, remete às concepções que tangenciam o tema da ação afirmativa e a seus significados para a sociedade mais ampla. As controvérsias em torno do uso das expressões mais adequadas nos conduzem a uma reflexão sobre a concepção de linguagem enquanto produtora de sentidos e a função política do discurso, melhor seria dizer: o discurso como um ato político.

É mais uma vez Foucault quem discute sobre "os efeitos de poder próprios do jogo enunciativo" (p.04). Sobre os regimes de verdade e as relações com afirmações de poder, o autor ressalta que:

\begin{abstract}
Há um combate pela verdade ou, ao menos, em torno da verdade - entendendose, mais uma vez, que por verdade não quero dizer 'o conjunto das regras segundo as quais se distingue o verdadeiro do falso e se atribui aos verdadeiros efeitos específicos de poder; entendendo-se também que não se trata de um combate "em favor" da verdade, mas em torno do estatuto da verdade e do papel econômico-político que ela desempenha. É preciso pensar os problemas os problemas políticos dos intelectuais não em termos de "ciência/ideologia", mas em termos de "verdade/poder. (1979, p.13)
\end{abstract}

As divergências fazem vir à tona os efeitos que os significados associados a este rótulo podem produzir na experiência subjetiva dos sujeitos. É como afirma uma das entrevistadas: "O ruim não é chamar 'cota', mas esclarecer o que é o termo. Não acho ruim serem chamados de cotistas, acho ruim se vira um rótulo ou parece que é um estereotipo".

Afirma Pais (2005) que:

\footnotetext{
${ }^{64}$ Entrevista com professor e pesquisador sobre o tema das ações afirmativas na universidade.
} 
A gramaticalidade de uma língua é um marcador de poder antes de ser um marcador sintático. A unidade de uma língua é fundamentalmente política. Mas na sua vivencia cotidiana, a língua participa em 'jogos de abertura' particularmente entre os que estão é margem do poder. (...) a língua remete para um sistema de convenções e de normas que determinam como se deve falar. A fala, em contrapartida, diz respeito à prática do uso linguístico - a qual a que os falantes façam usos distintos da língua. (p.113)

De outro modo, a dimensão ideológica e sobretudo político-social da linguagem presente em Bakhtin dialoga com as discussões em torno do uso das expressões "cotas" e "ação afirmativa" quando o autor explica:

\begin{abstract}
Toda enunciação monológica, inclusive uma inscrição num monumento, constitui um elemento inalienável da comunicação verbal. Toda enunciação, mesmo na forma imobilizada da escrita, é uma resposta a alguma coisa e é construída como tal. Não passa de um elo da cadeia dos atos de fala. Toda inscrição prolonga aquelas que a precederam, trava uma polêmica com elas, conta com as reações ativas da compreensão, antecipa-as. Cada inscrição constitui uma parte inalienável da ciência ou da literatura ou da vida política. Uma inscrição, como toda enunciação monológica, é produzida para ser compreendida, é orientada para uma leitura no contexto da vida científica ou da realidade literária do momento, isto é, no contexto do processo ideológico do qual ela é parte integrante. (p.101)
\end{abstract}

O que faz parecer este debate é a prevalência de estigmas associados a estudantes ingressantes pelo sistema de reserva de vagas, relativos aos argumentos contrários à política. A preocupação com o uso da linguagem apropriada reflete justamente a divisão de opiniões em torno do debate favorável ou contrário à política e os efeitos destas divergências, sobretudo dos argumentos que deslegitimam a reserva de vagas enquanto garantia de "direitos" antes vilipendiados, em contraposição a uma possível de concessão de privilégios associada a uma medida assistencialista. Analisando mais detidamente parte do discurso: "Falando cotas dá impressão que é um número fixo que tem ser preenchido. Não necessariamente, porque você precisa da aprovação do vestibular", verifica-se que a aprovação no vestibular seria um dos argumentos usados como forma de dar ênfase o mérito do estudante em estar na universidade, contrapondo-se a uma perspectiva filantrópica que o associaria a uma imagem de "incapacidade". A oposição entre "benefício" e "direito" ressurge disparada pela imagem a seguir: 


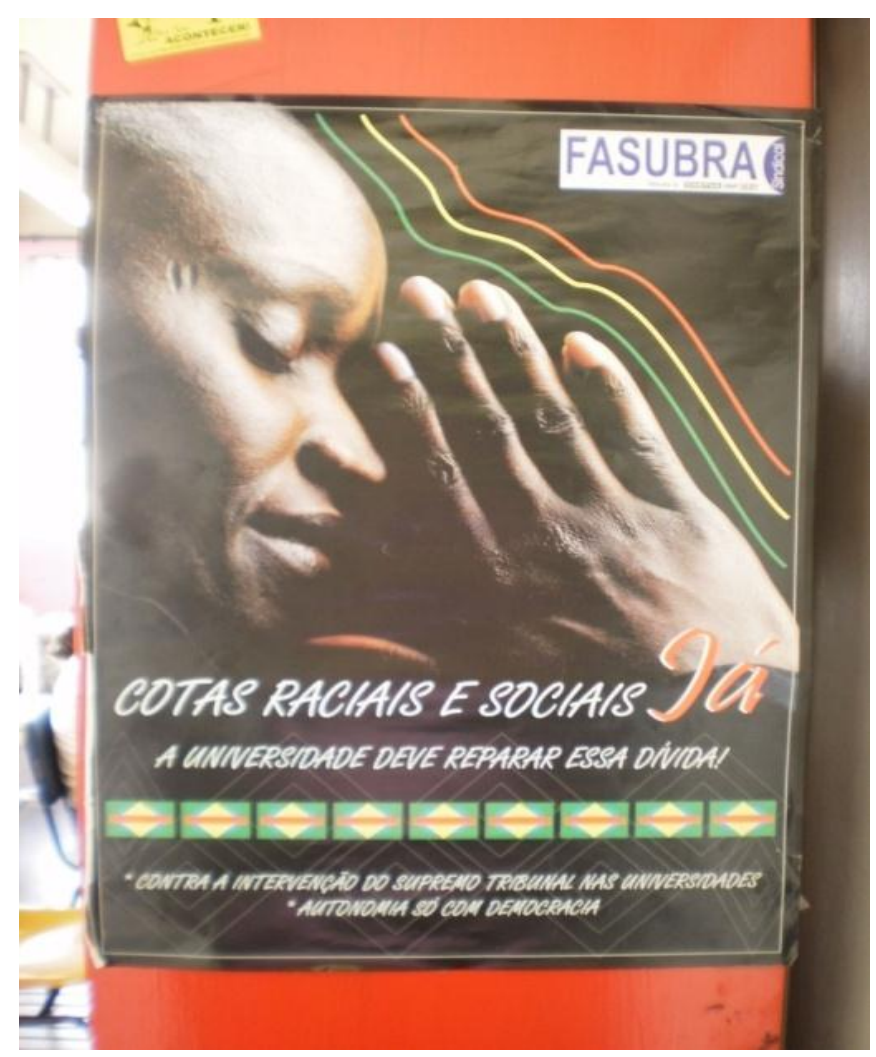

Foto 71 - Cartaz: "Cotas Sociais e Raciais já: A universidade tem que reparar essa dívida".

O cartaz foi encontrado em vários locais da UERJ, como centros acadêmicos e espaços institucionais. A princípio se poderia supor que suscitaria um debate envolvendo dois aspectos: a defesa da política de reserva de vagas com o cruzamento dos critérios racial e social e a universidade como o espaço responsável por reparar certa dívida ${ }^{65}$. Vejamos como as questões são abordadas nas falas dos entrevistados:

\footnotetext{
É isso aí: sociais! As pessoas por preconceito associam as cotas como raciais e esquecem que as cotas raciais são pra universidade reparar uma dívida que as pessoas ignoram. Seria pra contemplar as pessoas que hoje não se encaixam no sistema de cotas raciais, mas que também demandam e querem, podem, devem assumir e ocupar espaço. Essas cotas sociais são pra contemplar justamente as pessoas que vêm de fora, que as pessoas ignoram: o cearense, o nordestino. Essa galera de lá não é negra, mas vem pra cá e é a galera branca que tá na favela. Todo mundo fala, mas na favela também tem branco. Mas não é o branco que comanda a sociedade hoje, é o pobre, "fudido", que vem lá do nordeste. Na verdade, tudo tá associado ao passado, ao futuro, ao presente que têm várias ramificações e essas ramificações todo mundo põe pra jogo, tenta distorcer. Acho que a universidade tem que reparar essa dívida. Não só as universidades. Estão querendo colocar em
}

\footnotetext{
65 Abaixo do título principal do cartaz: cotas raciais e sociais já, se encontram os dizeres: a universidade tem que reparar essa dívida.
} 
concursos públicos cotas raciais. Não só as cotas raciais, mas sempre a cota racial é o jargão da vez, assim como hoje o jargão da vez tem sido a homofobia. (estudante)

O critério sócio-econômico que embasa as medidas distributivas das ações afirmativas se confronta com as medidas de reparação, argumento usado especificamente em defesa do recorte racial. Verifica-se que o discurso do entrevistado defende, fazendo uso de justificativas distintas, os critérios racial e social, sendo o primeiro uma condição de reparação da dívida histórica em razão da escravidão, e o segundo como forma de equiparação das condições socioeconômicas desiguais, incluindo, neste caso, os grupos brancos desprivilegiados, como no trecho em que o mesmo afirma: "Essas cotas sociais são pra contemplar justamente as pessoas que vêm de fora, que as pessoas ignoram: o cearense, o nordestino. Essa galera de lá não é negra, mas vem pra cá e é a galera branca que tá na favela”.

Em outra entrevista, o estudante se opõe ao critério racial em razão do argumento da dívida histórica, em específico. A condição socioeconômica é ressaltada como única possibilidade de justificar uma política de reserva de vagas para determinado grupo. Neste caso, a proveniência da formação na rede pública de ensino de base e a condição de "carência" justificam a defesa pela reserva de vagas sociais.

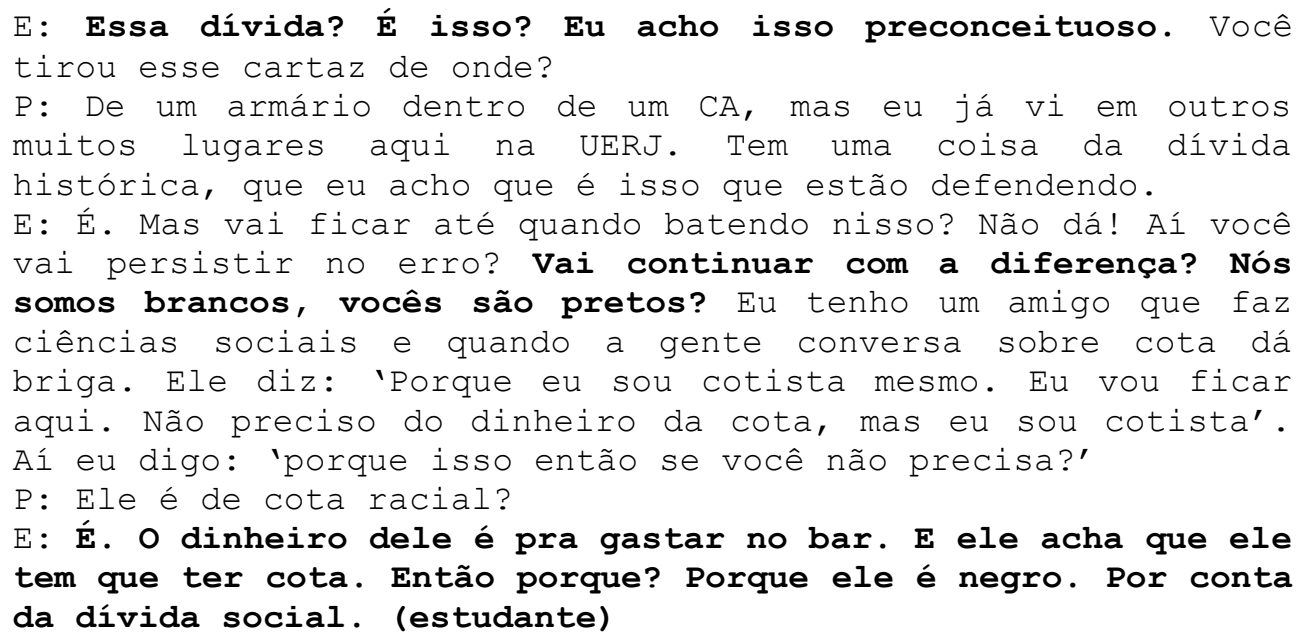

Os discursos evocam as tensões desencadeadas pelo uso do critério racial como recorte para reserva de vagas, discutidas no capítulo 2. Um dos argumentos usados em favor das cotas raciais é o da dívida histórica para/com a população afrodescendente em razão da escravidão. $O$ debate e a polêmica continuam e isso se reflete nas relações cotidianas da universidade. 
Neste contexto de tensões em torno do tema, a próxima imagemfotográfica apresentada deflagra de forma mais contundente as divergências quanto aos critérios de recorte para reserva de vagas e os argumentos contrários favoráveis.

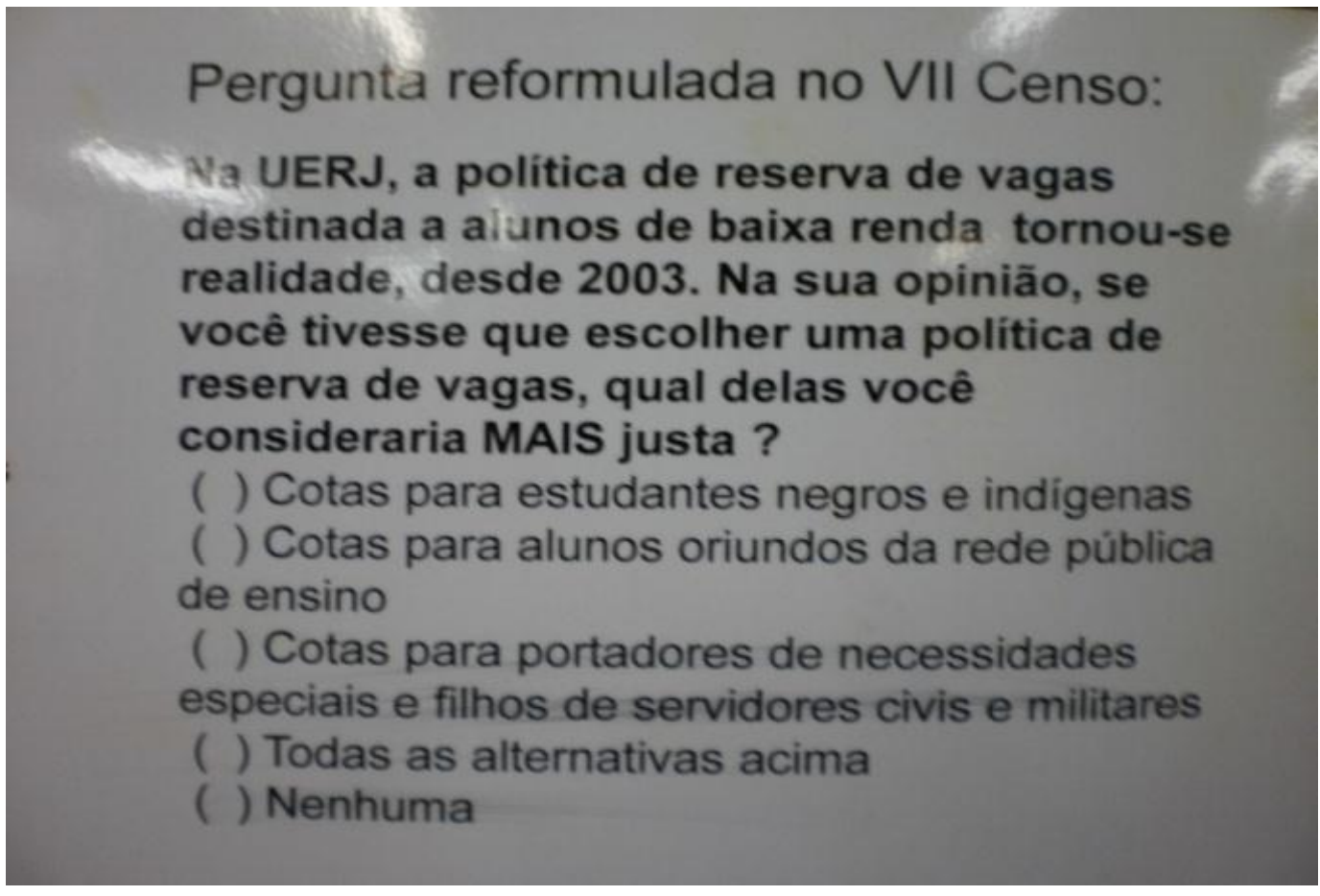

Foto 72 - "VII Censo UERJ_ política de reserva de vagas: qual o critério mais Justo?"

A pergunta feita no Censo da UERJ foi registrada em um dos murais oficiais da instituição. A questão convocou os entrevistados a explicitarem seus argumentos e justificativas na tomada de posições frente ao tema das cotas. Algumas divergências intragrupos surgiram deflagradas pela questão. Foram frequentes as diferenças de pontos de vista de integrantes afiliados a um mesmo grupo em relação à escolha dos critérios mais, ou menos justos, para uma política de reserva de vagas no ensino superior.

Integrantes de alguns grupos militantes da UERJ, em certos momentos, preocupavam-se em distinguir as posições individuais das dos coletivos aos quais se afiliavam. Havia uma preocupação em garantir que as posições pessoais não se confundissem com as coletivas, o que poderia comprometer a posição do grupo na "arena de disputas políticas" na universidade.

O debate sobre os recortes para reserva de vagas foi responsável por muitas destas divisões intragrupos. É o que sinaliza a discussão a seguir: 
E1: Engraçado quando você vai responder isso no site, colocam os indígenas junto com policiais militares e bombeiros. Não colocam indígenas separados.

E2: Eu defendo cotas para alunos oriundos da rede pública de ensino.

E1: Eu não. Eu acho negros.

E2: Negros vocês já classifica dentro dos estudantes das redes públicas. A maior parte dos estudantes da rede pública de ensino são negros.

E1: Sim, mas tem muita gente que não é negro e que não tem condições financeiras.

E2: Então eu acho que na rede pública de ensino tem gente que não tem condições financeiras e que não tem uma educação boa.

E1: Eu discordo. (estudantes)

Cotas pra estudantes negros e indígenas eu acho um absurdo. Cotas pra alunos oriundos da rede pública de ensino é uma coisa que tem que ser remodelada, mas tem um fundo de razão sim. Você vê aqui: a rede pública é Pedro Segundo, CEFET. Isso eu sou contra. Agora, quando as escolas realmente são escolas estaduais que dão uma boa base pro aluno, eu acho viável sim. Apesar de eu achar a reserva de vagas muito grande. 25\%! A ponto do aluno entrar com 2 numa reserva de vagas quando se entra com 7. Acho que a reserva é grande demais. Essa cota poderia ser refeita. Teria algum sentido sim. Portadores de deficiência eu acho totalmente certo. Prejudicaram esses alunos a vida toda, estudantil, então tem que ter essa compensação. Agora, essa cota da rede publica pode abarcar os negros se levar em consideração que, se negro teve acesso a uma escola particular, boa, CEL, Santo Inácio, Santo Agostinho, não sei porque ele deveria entrar pela reserva de vagas. Ele teve condições. (estudante) maior.

E1: Cotas para a rede pública. Porque o critério é muito

E1: Rede pública.

E1: Um que eu nunca consegui entender é a cota pra filho de servidores.

E2: É aquele negocio de pós-guerra, continua até hoje.

E2: Isso aí é pra praça, gente? mundial.

E1: Isso começou por causa dos que voltaram da segunda guerra

E20: Não tem direito. É só praça.

E2: Mas bombeiro pode.

E1: Sim, mas existe uma diferença entre praça e oficial. O oficial ganha bem e o praça ganha mal. Oficial não tem direito. E2: Seu pai é praça?

E1: Meu pai era soldado da PM. (estudantes)

Em relação às cotas raciais, acho que não deveriam existir. Já gera um preconceito aí: "Sou cotista porque eu sou negro". Cor da pele? Tudo bem que tem todo um histórico de que os negros são os mais pobres. Essa política de cotas veio pra durar dez anos, porque ela acha que vai conseguir elevar o nível social das pessoas que são negras. Eu acho uma viagem. (estudante) 
Em Arendt (1998), sobre o conceito de política, encontramos a seguinte afirmação:

A política trata da convivência entre diferentes. Os homens se organizam politicamente para certas coisas em comum, essenciais num caos absoluto, ou a partir do caos absoluto das diferenças. Enquanto os homens organizam corpos políticos sobre a família, em cujo quadro familiar se entendem, o parentesco significa, em diversos graus, por um lado aquilo que pode ligar os mais diferentes e por outro aquilo pelo qual formas individuais semelhantes podem separar-se de novo umas das outras e umas contra as outras. (p.22)

Pondo em análise a política de reserva de vagas com a intenção maior de conhecer as experiências das práticas cotidianas que a proposta faz deflagrar a partir de sua implementação na universidade, outras questões emergem referentes, sobretudo, ao "fazer político" no contemporâneo.

O que se pode verificar, através dos discursos, é que não se tratam de grupos homogêneos, mas de coletivos constituídos por sujeitos com identificações e distanciamentos. O termo "coletivo", aqui utilizado, se afilia ao sentido dado por Guattari (1992) enquanto:

Uma multiplicidade que se desenvolve para além do indivíduo, junto ao socius, assim como aquém da pessoa; junto a intensidades pré-verbais, derivando de uma lógica dos afetos mais do que de uma lógica de conjuntos bem circunscritos. (p.20)

Partindo desta definição, se produziriam subjetividades justamente entremeadas por essa hibridização, numa dinâmica que é, sobretudo, processual e contingencial. É neste momento que cabe esclarecer a concepção de subjetividade a partir da qual se pretende basear a análise dos discursos e das práticas cotidianas, imbricadas com o sistema de reserva de vagas na UERJ: "A subjetividade, de fato, é plural, polifônica, para retomar uma expressão de Mikhail Bakhtin. E ela não conhece nenhuma instância dominante de determinação que guie as outras instâncias segundo uma causalidade unívoca". (Guattari, 1992, p.11)

A concepção de subjetividade acima descrita remete à existência de uma heterogeneidade de fatores como seus componentes. Os mesmos autores definem subjetividade como: "O conjunto das condições que torna possível que instâncias individuais e/ou coletivas estejam em posição de emergir como território existencial auto-referencial; em adjacência ou em relação de delimitação com uma alteridade ela mesma subjetiva". (Guattari, 1992, p.19). 
Uma vez aprovada, a política de reserva de vagas na UERJ tem reunido, em um mesmo espaço de convivência, os favoráveis à reserva de vagas para estudantes da rede pública de ensino, mas desfavoráveis ao critério racial; os favoráveis a ambos os critérios; os favoráveis somente ao critério racial; os desfavoráveis à política independente do critério de ingresso; os alheios à discussão; os ingressantes à reserva de vagas para portadores de necessidades especiais; dentre vários outros.

As imagens apresentadas nas entrevistas fizeram emergir alguns discursos que circulam pela universidade e que formam uma espécie de "rede de falatórios". ${ }^{66}$ Entremeada por discursos de toda ordem, a questão que precisa ser analisada refere-se aos efeitos provocados pelas, então, "rede de falatórios" nas experiências dos estudantes na universidade. As justificativas que antes situavam o debate sobre as cotas opondo dicotomicamente grupos favoráveis e contrários à política, acalentando as "rodas de conversa" nos espaços extramuros da universidade, passam, com a implementação da política, a afetar a trajetória e as relações interpessoais no espaço intraescolar. Analisemos os discursos e a relação com o debate mais amplo, nos seus efeitos e desdobramentos:

\subsubsection{B) A nota de corte do vestibular: a resignificação do princípio do mérito}

Dentre os argumentos contrários à reserva de vagas, independente do recorte, está a mudança nas notas de corte no processo seletivo do vestibular. Argumenta-se que, em alguns cursos mais elitizados, a política teria "facilitado" a entrada de estudantes de reserva de vagas e, ao mesmo tempo, dificultado o ingresso dos demais, especialmente no tocante aos cursos com maior relação candidato-vaga.

\footnotetext{
E1: Eu sou contra cotas. Só que a UERJ foi a primeira universidade a implementar esse programa porque o governo do estado simplesmente mandou botar na assembleia legislativa, sem nenhuma conversa com a universidade, sem saber a capacidade que a universidade tinha pra absorver essa nova situação proposta. Nós ainda tentamos ter uma discussão, mas já foi um pouco tardia. O fato é que a lei foi votada e a UERJ teve que assumir. Esse debate só ta acontecendo a nível
}

\footnotetext{
${ }^{66}$ Esta distinção/identificação entre o que é verdade e o que é boato importa menos tendo em vista que ambos, "verdades" e "boatos", constroem sentidos e produzem realidades, atravessando as práticas cotidianas dos sujeitos neste espaço.
} 


\begin{abstract}
das Federais, que levaram esse tempo todo relutando em aceitar essa proposta colocada de cima pra baixo. Têm até senadores que disseram o seguinte, e eu até aceito esse posicionamento. Um "senador do bem". Ele diz que não tinha que ter cota nenhuma, porque isso é como se tivesse dando uma esmola pra raça negra, julgando inferior, incapaz. Porque entrar na universidade com uma nota mais baixa do que o outro que se preparou e que esteve nos melhores colégios, que não precisa nem fazer cursinho pré-vestibular pra passar? Os alunos do CAP não precisam fazer cursinho. Eles estão terminando os últimos anos do segundo grau, se inscrevem no vestibular e passam pra UERJ, pra UFF, pra Rural, pra Unirio, pra Unicamp, pra todas as universidades.

E2: E os nossos cotistas passam sempre com notas altas.

E3: Porque têm uma boa escolaridade na base. Um aluno de escola pública de hoje, antigamente era boa, que já começa mal o primeiro grau, o segundo grau pior ainda, que base que esse cara tem pra entrar numa universidade e acompanhar a grade curricular normal? A grade curricular não vai ser unificada porque eu passei com nota baixa. Eu até confio que ele vai se esforçar pra recuperar sua deficiência e se igualar aos demais, que tiveram uma bagagem melhor de conhecimento, mas é uma grande dificuldade que o cara vai encarar. Talvez muitos não consigam terminar o curso. Não precisa ter cota pro cara entrar com a nota baixa e poder ingressar na universidade. O que o governo tem que investir é na educação, é no ensino público de qualidade, no primeiro e no segundo grau para todos, independente de cor. (funcionário)
\end{abstract}

O trecho acima aponta as distintas opiniões sobre a política de cotas dentro de um mesmo grupo. Verifica-se que os argumentos oscilam entre a defesa da capacidade intelectual dos estudantes cotistas, com ressalvas para o desempenho acadêmico destes estudantes e a compatibilidade com os demais estudantes da universidade - o que refuta os boatos de que estes não seriam capazes de acompanhar o rendimento acadêmico e/ou abaixariam o nível da universidade - e a posição contrária às cotas, atribuindo justamente à política a prerrogativa de incapacidade, da qual, ao que parece, se quer refutar.

Os argumentos se misturam quando na assertiva: 'Um 'senador do bem' (...) diz que não tinha que ter cota nenhuma, porque isso é como se tivesse dando uma esmola pra raça negra, julgando inferior, incapaz", um dos sujeitos da pesquisa defende que as cotas seriam uma concessão - uma "esmola"-, numa perspectiva assistencialista e, ao mesmo tempo, em momento posterior, aponta-se a disparidade entre as redes pública e privada de ensino como fator responsável pelas diferenças de desempenho no processo seletivo no vestibular. Embora a constatação de que o desempenho dos estudantes seja desigual em função da iniquidade de condições de acesso a um ensino de base qualificado, a questão do mérito assume maior peso valorativo quando as notas distintas no processo seletivo do vestibular configuram injustiça, já que um "favor". 
A opinião seguinte, de um estudante, dialoga com o discurso anterior quando traz dados sobre o desempenho favorável de "estudantes cotistas" de modo a refutar a hipótese de que os mesmos não seriam capazes de acompanhar o rendimento acadêmico dos demais alunos.

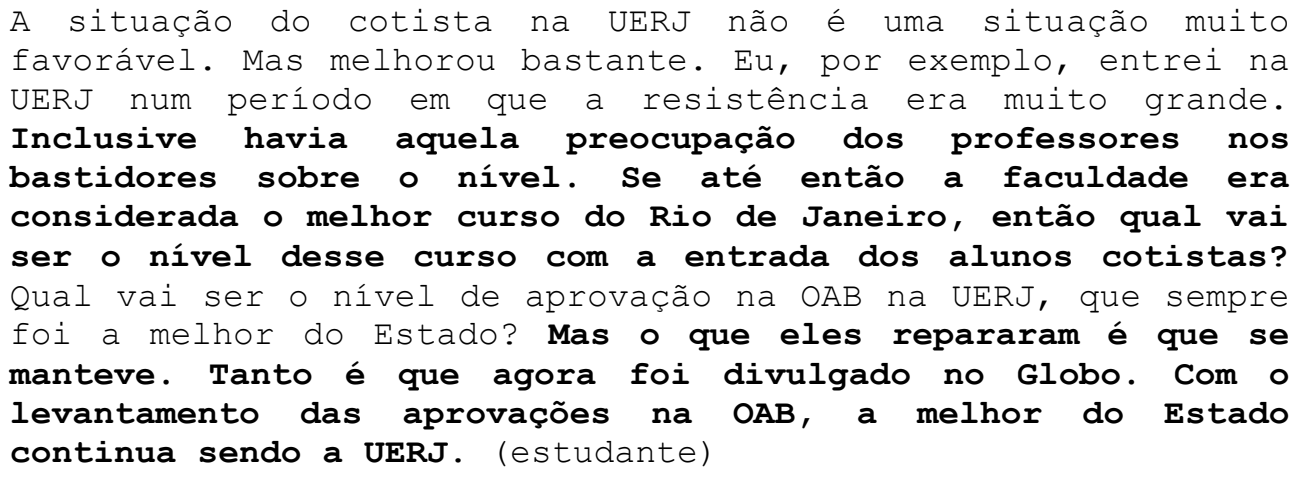

Há um conjunto de argumentos contrários às cotas que, ao que faz parecer, acaba imputando estereótipos nos "estudantes-cotistas", que precisam criar saídas e táticas de combate como forma de auto-valorização e de afirmação do seu direito de estar na universidade.

Em pesquisa realizada na PUC-Rio ${ }^{67}$, depoimentos de estudantes oriundos de pré-vestibulares comunitários que vivenciavam a experiência de estudarem em uma universidade voltada para uma elite econômica, até o momento da pesquisa, sinalizaram as dificuldades em manter-se na universidade permeados por "fantasmas" e estereótipos que colocavam em questão a capacidade e o direito de estarem naquela universidade. A preocupação com a manutenção do nível alto dos CRs (coeficientes de rendimento acadêmico) e o argumento da aprovação no mesmo processo seletivo do vestibular que os demais estudantes, foram enfatizados nos depoimentos, como forma de afirmar sua importância e o direito de fazerem parte do corpo discente da instituição.

Barcellos (2007) analisa a pesquisa elencando algumas frases que aparecem nos discursos dos estudantes entrevistados com certa frequência, quais sejam: 1. "Eu passei no vestibular da PUC, assim como todos os outros alunos da Universidade"; 2. "Minha presença na universidade não é um favor, é uma troca!"; 3. "Os nossos CRs são altos!";4."Eu sou importante para a universidade porque trago como bagagem um bem escasso no local, o que chamo de capital humano".

\footnotetext{
${ }^{67}$ Pesquisa que desencadeou a dissertação de mestrado "jovens de pré-vestibulares comunitários na PUC-Rio: Experiências e Táticas no convívio com a alteridade", defendida em 2007 (ver referencia em anexo).
} 
As frases citadas acima, intituladas "estratégias de auto-valorização", "têm um caráter de responsividade". (Barcellos, 2007). Vale serem retomadas as considerações feitas à época da pesquisa:

\begin{abstract}
Elas são usadas como respostas a possíveis argumentos que possam vir a rejeitar suas presenças naquele espaço. Logo, elas não surgem no vazio. Se há um esforço no sentido de refutar certos modos de pensamento é porque estes estiveram presentes, de alguma maneira, ou ainda, estão no imaginário ou na representação de alguns atores que compõem o contexto universitário e na sociedade civil, mais amplamente. As próprias histórias e relatos dos estudantes demonstraram o esforço dos próprios em refutarem certos argumentos. (Barcellos, 2007, p.147)
\end{abstract}

É como diz Bakhtin:

Toda compreensão da fala viva, do enunciado vivo é de natureza ativamente responsiva (embora o grau desse ativismo seja bastante diverso); toda compreensão é preenhe de resposta, e nessa ou naquela forma a gera obrigatoriamente: o ouvinte se torna falante. A compreensão passiva do significado do discurso ouvido é apenas um momento abstrato da compreensão ativamente responsiva rela e plena, que atualiza na subsequente resposta em voz alta. (...) portanto toda compreensão plena real é ativamente responsiva e não é senão uma fase inicial preparatória da resposta (seja qual for a forma em que ela se dê) (Bakhtin, 2003, p.271/272)

As entrevistas na UERJ apontam semelhanças nas trajetórias de alguns estudantes com as daqueles estudantes da PUC-Rio. Entretanto, a reserva de vagas agrava a discussão, justamente em função das diferenças entre as notas de corte de estudantes da reserva de vagas e as dos demais. O princípio da meritocracia, que formata os processos de seleção nas universidades precisa ser resignificado e contextualizado sócio-historicamente, especialmente se consideradas as especificidades das condições brasileiras. Vejamos a discussão refletida na fala de um dos sujeitos da pesquisa na UERJ:

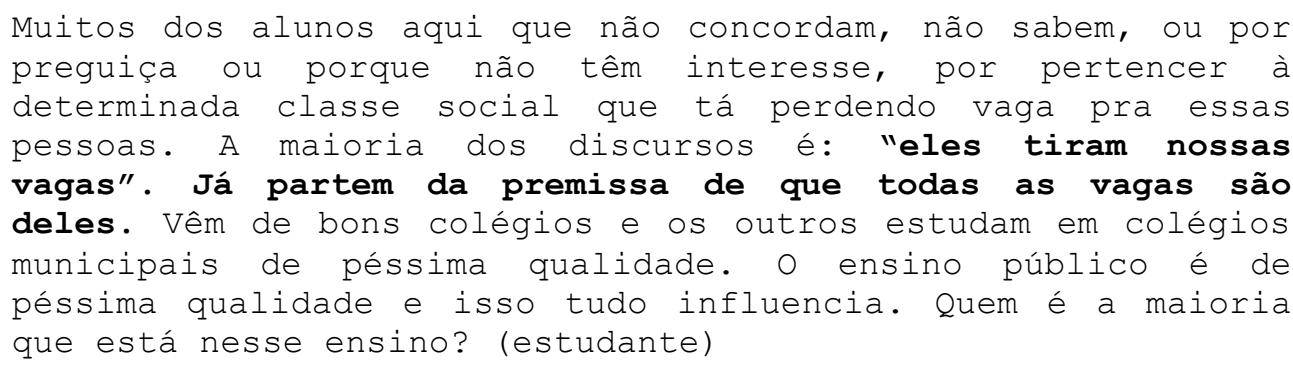

O discurso acima retoma os rumos que dicotomizam a discussão entre direito e benefício. Há os que entendem a reserva de vagas como concessão de privilégios. Há, em contrapartida os que defendem a política, num rol mais amplo 
de ações afirmativas, em uma perspectiva de garantia de direitos, caso da fala: "A gente tenta sempre colocar que é um direito da pessoa". (referindo-se à distribuição do kit-cotista.)

A tensão desencadeada pelos termos direito e benefício, instaurada pela busca dos estudantes cotistas em afirmarem seus direitos de estarem no espaço da universidade, nos remete à importante discussão do conceito de cidadania. Não se trata de priorizar um entendimento do conceito - cidadania exclusivamente atrelado à garantia de direitos universais, apesar de serem condição básica de seu exercício. Castro (2001), referindo-se à cidadania de jovens e crianças na cidade contemporânea, analisa o termo a partir de um desdobramento nos direitos civis e políticos mas também sociais,. (p.116)

Castro (2001) faz referência a Carvalho (2001) afirmando que:

As pessoas se tornam cidadãs à medida que passam a sentir-se parte de uma nação e de um Estado, onde a lealdade ao Estado e a identificação a uma nação são elementos imprescindíveis. Tanto sentir-se parte, como identificar-se constituem condições subjetivantes da cidadania, isto é, só haverá exercício efetivo da cidadania quando este sujeito (...) encontre condições que favoreçam seu pertencimento e sua identificação a algo maior que é a sua nação ou o seu Estado. (p.117).

Em se tratando das afirmativas dos e sobre os estudantes cotistas de cunho auto-valorativo, em busca da afirmação do direito de estarem na universidade, as mesmas encaminham reflexões sobre os possíveis efeitos do discurso do "benefício" que podem recair sobre os estudantes. A sensação de que a universidade não lhes pertence, uma vez que seria destinada para outros estudantes que tiveram supostamente suas vagas usurpadas, provocaria um sentimento de "estrangeirismo", de não-pertencimento, que possivelmente marcaria subjetiva e negativamente seus trajetos no processo de formação no ensino superior.

Se por um lado, a oposição entre as opiniões favoráveis e as contrárias à política de reserva de vagas reverbera efeitos na constituição identitária dos estudantes ingressantes pelo sistema de reserva de vagas, por outro, o conceito de identidade ressurge, suscitando controvérsias e divergências, quando são estipulados grupos específicos para os quais é conferida a possibilidade de concorrerem às vagas reservadas.

Os critérios utilizados para estabelecer quem se enquadraria a uma ou outra política de reserva de vagas - racial, rede pública de ensino, entre outros -, fazem eclodir reflexões sobre as concepções de "pertencimento" e "identificação" 
e sobre modos de produção de subjetividade na dialética com a cultura e com a sociedade. É o que suscita a questão presente na imagem-fotográfica a seguir:

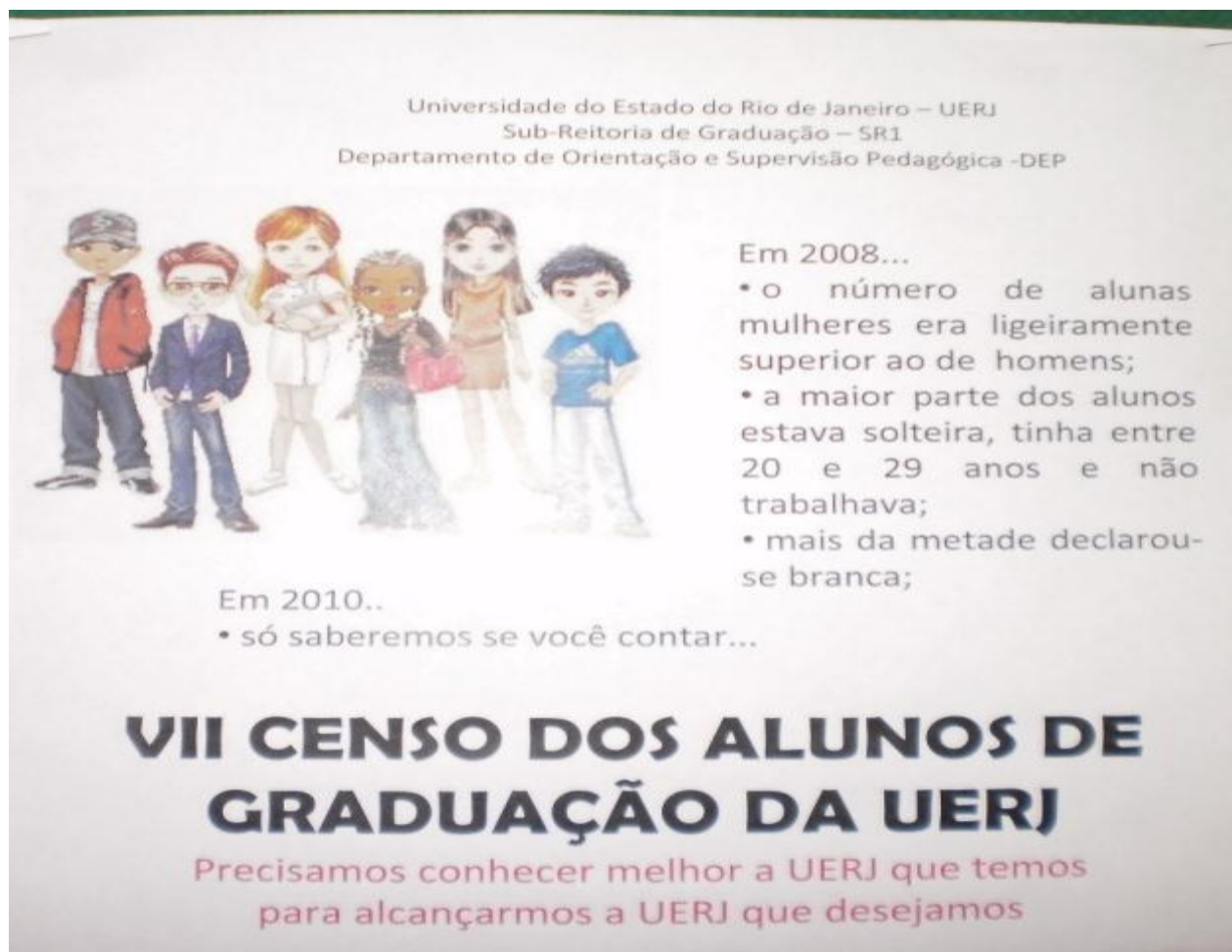

Foto - 73 - Censo UERJ - perfil estudante

O cartaz, ainda tratando do Censo da UERJ, traz como um dos aspectos a autodeclaração - "mais da metade declarou-se branca" - estratégia usada para estabelecer quais os estudantes poderiam concorrer pelo sistema de reserva de vagas de recorte racial. A autodeclaração pressuporia que a definição étnica dependeria do modo como cada estudante se percebe e, portanto, se autodeclara, como comenta o entrevistado no trecho em destaque:

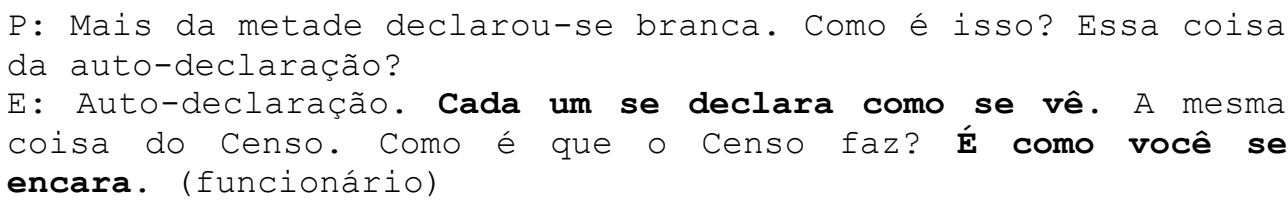

As constatações presentes nas assertivas "cada um se declara como se vê" e "é como você se encara", nos remetem aos pressupostos que pautam as chamadas políticas de reconhecimento, tratadas no capítulo 2. As propostas de ação afirmativa não se propõem exclusivamente a reparar as desigualdades do ponto de vista de uma equiparação nas condições financeiras e educacionais, mas também, a promover ações que tornem reconhecidos socialmente os grupos-alvo de preconceitos e discriminação sociais. Para tanto, solicita-se, 
através do critério de auto-declaração, que os estudantes que optarem por ingressar pelo "sistema de cotas" via critério racial se identifiquem como tais. É deste ponto específico que surgem as maiores divergências e tensões.

\subsubsection{C) As cotas raciais: a discussão racial e o preconceito em debate}

A política de maior repercussão quando da implementação da proposta, sobretudo nas universidades pioneiras - UERJ, UNB, UNEB - foi a reserva de vagas para afrodescendentes. Os argumentos mais frequentes nos fóruns de debate, à época da consolidação da política, aparecem nos discursos dos sujeitos que vivenciam a proposta na UERJ.

O critério racial usado para reserva de vagas na universidade fez deflagrar discussões que atravessam as relações sociais no Brasil, de modo mais amplo, o que explica a grande mobilização em torno do assunto. Algumas das questões que perpassam o cenário acadêmico retornam nas vozes dos sujeitos da pesquisa. O que fica mais proeminente é o fato deste tema, mais do que qualquer outro, provocar divergências dentro dos próprios grupos.

Destacam-se, dentre os temas que tangenciam mais recorrentemente a polêmica em torno do recorte racial como critério, a discussão sobre o racismo e a identificação racial no Brasil.

Estas discussões colocam em questão o "mito da democracia racial". A premissa de ausência de racismo no país deslegitima a constitucionalidade e pertinência das ações afirmativas de cunho racial, quando a justificativa-base para as ações estão associadas às chamadas 'políticas de reconhecimento'.

É novamente Salvador (2008) quem nos esclarece distinguindo as políticas de reconhecimento das redistributivas ${ }^{68}$ no trecho a seguir:

\footnotetext{
Um dos maiores desafios da democracia contemporânea tem sido o de encontrar respostas políticas capazes de reduzir as desigualdades sociais. Nesse debate, aparecem duas propostas distintas: as políticas redistributivas, dirigidas para redução das carências econômicas, e as políticas de reconhecimento, voltadas para a valorização de identidades desrespeitadas. As políticas redistributivas estariam, então, mais voltadas para a garantia de igualdade econômica e se concretizariam, principalmente, através da redistribuição de renda, enquanto as políticas de reconhecimento estariam voltadas para a redução das desigualdades sociais, baseadas em aspectos identitários e culturais. (Salvador, 2008, p.29)
}

\footnotetext{
${ }^{68}$ Ver análises feitas no capitulo 2.
} 
Salvador (2008) toca no segundo aspecto, subjacente ao primeiro - a identificação racial no Brasil - o que provoca ainda mais divergências na medida em que, um dos argumentos usados contra as cotas raciais baseia-se no pressuposto da população brasileira como uma nação miscigenada, o que inviabilizaria uma identificação objetiva dos que seriam ou não contemplados pela reserva de vagas com recorte racial.

A temática sobre a identificação étnica aparece mais veemente no momento em que esta imagem-fotográfica é apresentada a alguns entrevistados:

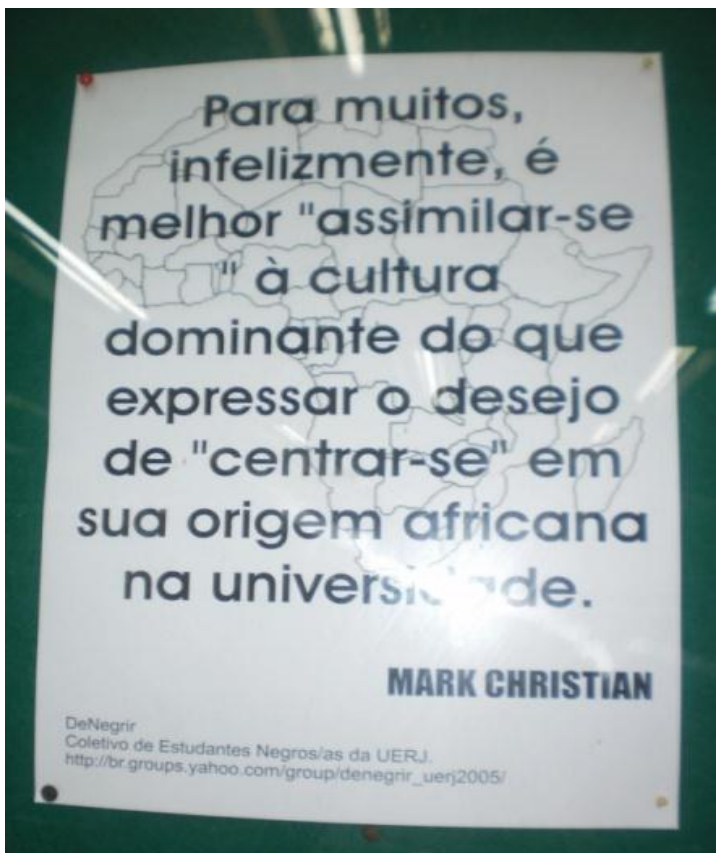

Foto 74 - "Denegrir_ Mural no hall do 'queijo'

Os dizeres foram fotografados no mural do Denegrir - Coletivo de estudantes negros da UERJ. ${ }^{69}$ Os dizeres trazidos na imagem fizeram emergir diferentes visões sobre o tema do racismo e os modos de enfrentamento da problemática no Brasil. Seguem alguns debates a seguir:

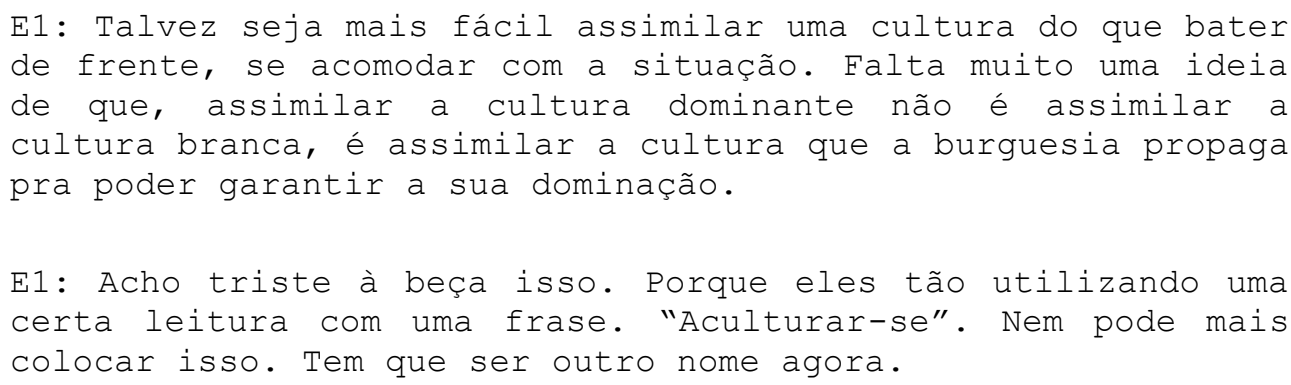

\footnotetext{
${ }^{69}$ Texto afixado no mural do Denegrir - Coletivos de Estudantes Negros da UERJ. Vale esclarecer que houve tentativas durante o processo de pesquisa de contatar o grupo, porém sem sucesso.
} 
E2: É. "Aculturar-se", "Assimilar-se", não se usa mais. Tanto do índio quanto do negro. A cultura do homem branco, a cultura portuguesa, é uma cultura dominante. Ao longo do tempo, nós absorvemos mas, mesmo assim, nós criamos determinados mecanismos pra gente ainda continuar com nossa cultura, a cultura afrodescendente. O exemplo disso é a Umbanda.

E1: Eu acho que eles exageram muito nisso. Se tivesse cabelo duro não ía poder alisar o cabelo. Quando você diz que você tem a sua cultura, você esquece que pode conviver em outro lugar e a cultura vai se resignificando em alguma outra coisa. A cultura, a identidade, é uma coisa extremamente complexa. Você tem que tomar cuidado quando vai escrever sobre. Porque pode tomar como verdade e quando essas verdades realmente ficam consolidadas, viram uma coisa muito concreta, e tudo que é concreto é completamente diferente da cultura, da própria identidade. Nós estamos sempre num estado de estar. A cultura, a identidade, não vai permanecer sendo. Embora possa parecer que a pessoa está inserida numa cultura, depende do que ela acha bonito nela. Se ela for negra e achar - cabelo mais bonito, liso, porque o rosto dela é mais fino, é mais largo, ela vai botar o cabelo nela fino. A minha filha tem o cabelo cheio de cachinho e pode querer pintar o cabelo de vermelho e alisar. Eu vou fazer $O$ que? Eu sinceramente preferia meu cabelo com cacho, é muito fino! Mas eu não consigo colocar cacho nessa "meleca"! Acho que cabe a você entender o que fica mais bonito em você.

E2: Até a própria concepção de beleza. A pessoa foi gerada com uma determinada visão de mundo.

E1: Eu acho que uma pessoa não precisa centrar na sua origem africana pra ser ela mesma. Ela usa o cabelo dela como ela quiser, ela se veste como ela quiser, tudo depende dela.

(estudantes)

Se a gente fosse pegar pela questão racial, os jovens que mais são prejudicados são os negros. Eu não sou nem tão negro assim. Eu me acho negro, mas tem gente que fala: "Você tá sendo ridículo! Ta defendendo tudo isso e você nem é negro!" Eu disse: "Quem é você pra dizer que eu não sou negro? Eu me acho negro, eu sou negro. Você, pela minha cútis, pode tá achando que eu sou mais "clarinho" e isso significa que eu não sou negro? "Mas olha só teu cabelo!". "Mas isso não quer dizer nada! A gente é misturado". "Você não tá com essa capacidade crítica de conhecer seus antepassados, saber porque você hoje não se considera negro. Nosso processo cultural foi exterminado pra vocês de fato não saberem disso, pra não tomarem conhecimento disso, não se interessarem. Porque é uma cultura muito bonita. Eu não ouço isso mais porque eu só ando de moto, mas há um tempo atrás, eu só andava de ônibus. De eu tá dormindo, de tá acordado, e tá um monte de gente no ônibus e só eu ser pedido pra abrir mochila. E olha que eu não sou nem tão escuro assim! Só EU ser pedido pra abrir mochila! Só EU ser pedido pra ser revistado! (estudante)

Algumas reflexões podem ser feitas a partir destes discursos. Sant'Anna (2004) põe em pauta a discussão sobre direitos humanos, especialmente nas 
últimas décadas, sintetizando-o na assertiva: "todo ser humano é diferente." (p.173) Segundo o autor:

Se a aparência física é o que, num primeiro momento, nos distingue como indivíduos, a nossa singularidade como seres humanos, aporta uma rede complexa de relações sociais que faz com que sejamos não apenas distintos dos outros, mas especialmente, diferentes em nosso comportamento, personalidade, sensibilidade, sexualidade, talentos, gênero, raça, etnia e nacionalidade. Assim, apesar de sermos todos membros do que chamamos de humanidade, a luta pela universalidade dos direitos humanos hoje, mais do que nunca, organiza-se, fundamentalmente, como a luta pelo direito a produção de novas singularidades, no sentido de reconhecimento da igualdade na diferença. (p.173)

Afonso \& Rodrigues (2003) analisam as políticas de reconhecimento na interface com as políticas de redistribuição, no cerne das ações afirmativas para o ensino superior no Brasil. Referente às primeiras, os autores afirmam ressaltam a importância destas ações como forma de promoção da igualdade social. Defendem os autores:

As políticas de reconhecimento necessitam ser igualitárias, fugindo da homogeneização proposta pelos interesses dos grupos dominantes, que encurralam o grupo minoritário em uma percepção negativa de si mesmo, em que não encontram nem fora nem dentro de grupo modelos de identificação que sejam satisfatórios. (p.275)

Alegando que, do ponto de vista política, contudo, há a prevalência de condições de exclusão social do negro, das mulheres, dos homossexuais em decorrência de um "ideal de igualdade a serviço da manutenção do status quo." (p.275). Afonso \& Rodrigues (2003) citam a seguintes palavras de Santos (1997, 29):

\footnotetext{
Das diferentes versões de uma dada cultura deve ser escolhida aquela que representa o círculo mais amplo de reciprocidade dentro dessa cultura, a versão que vai mais longe no reconhecimento do outro (...) As pessoas e os grupos sociais tem o direito a ser iguais quando a diferença os inferioriza, e o direito a ser diferentes quando a igualdade os descaracteriza. (Santos, 1997, p. 29 in: Afonso \& Rodrigues, 2003, p.275)
}

Não é sem sentido que os dizeres contidos na imagem-fotográfica acima tenham desencadeado discussões sobre estética, numa dimensão ético-política, e a relação com a identidade. As discussões poderiam pender para caminhos variados. Por ora, analisemos duas perspectivas.

As palavras de Pais (2005) sobre os modos de expressão identitária de jovens de diferentes grupos denotam que: 
As identidades são uma construção que se logra na imagem, na linguagem, nas formas de comunicação e de consumo, com recurso a múltiplas estratégias cênicas. (Canclini, 1995). (...) num cenário de forte reivindicação de direito ao uso livre do corpo, a cidadania problematiza-se cada vez mais nos domínios do self, do corpo, da sexualidade, refletindo a individualização da cultura. (p.111)

A outra perspectiva de análise, que se relaciona com a primeira, alude à busca de processos de singularização, portanto de resistência, às identidades culturais hegemônicas disseminadas pela cultura capitalista. É como diz Sant'Anna (2004):

\begin{abstract}
Como processo de singularizaçao, as chamadas 'minorias', grupos excluídos ou transgressores, representam frustrações dos mecanismos de interiorização dos valores capitalísticos modernos, uma recursa a subjetivação capitalística que forja uma identidade cultural globalizada pelos interesses hegemônicos dos países centrais e que se apresentam, paradigmaticamente, como monocultural, branca, masculina e heterossexual. (p.174)
\end{abstract}

\title{
E continua:
}

Como resistência, os grupos dominados e excluídos (...) precisam construir seus processos de singularização a partir de seus próprios referenciais práticos e teóricos, livrando-se da dependência em relação ao poder global em todos os seus campos, do societal ao epistemológico. (174)

A polêmica gerada em torno do recorte racial e dos critérios usados como forma de identificação - autodeclaração, no caso da UERJ - traz para o debate disciplinas que se propõem a analisar, a partir do discurso científico, conceitos como identidade, raça, etnia, dentre outros. É desta forma que a antropologia, sociologia e disciplinas afins entram no debate na tentativa de fornecer subsídios teóricos para uma determinação objetiva sobre a legitimidade da política nos seus moldes atuais e suas estratégias de efetivação.

A noção de identidade abre brecha para diversas análises e concepções, sobretudo, no campo da ciência psicológica. Os paradigmas que embasam o conceito de identidade, na interface com um modo de pensar/fazer psicologia que entende sujeito em uma relação dialética com a sociedade, priorizam antes a formação desta identidade e as relações que se estabelecem no contexto sócio-histórico em que o sujeito - que se constitui da e na experiência - se insere.

Vale distinguir e clarificar os conceitos de identidade, individualidade e subjetividade, que em alguns momentos confundem-se quanto às suas significações. Miranda (2005), pautada em Guattari, explica: 


\begin{abstract}
A identidade, segundo Guattari, frequentemente está ligada a algum tipo de reconhecimento, seja ele individual ou coletivo, a um quadro de referência que perpassa enquanto identificação do indivíduo - nome, filiação, impressão digital ou quanto ao processo de identificação freudiano: "a identidade é aquilo que faz passar a singularidade de diferentes maneiras de existir por um só e mesmo quadro de referência identificável. (Guattari e rolnik, 1986: p.68-69 In: Miranda, 2005: p. 37/38) A subjetividade de um indivíduo diz respeito menos à identidade $e$ mais à singularidade, isto é, possibilidade de viver a existência de uma forma única, no entrecruzamento de diversos vetores de subjetivação. Por outro lado, a singularidade não está circunscrita somente ao indivíduo, mas há singularizações presentes nos grupos ou em instituições. Portanto, a subjetividade de um indivíduo é marcada menos por uma etiqueta identificatória do que pela diversidade, pela heterogeneidade dos modos que ela pode assumir. (Miranda, 2005: p.37/38
\end{abstract}

Duas passagens do discurso de um dos entrevistados nos fazem refletir sobre o processo de identificação e produção da subjetividade, quando o mesmo reivindica o direito dele próprio definir-se e identificar-se frente à imposição de um conjunto de regras normativas que visam delimitar de forma categórica sua identidade étnico/racial.

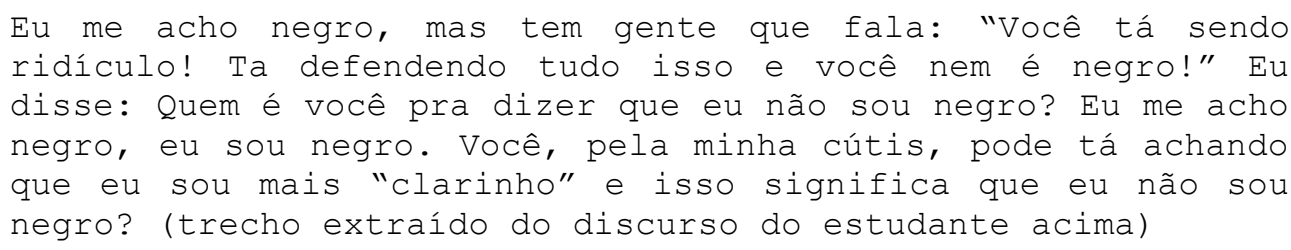

O tom da pele - tomando por base o discurso do estudante - não é parêmetro para delimitar sua condição de negritude. Mas esta discussão não se encerra aqui. Há desdobramentos.

Quando o critério de autodeclaração prevê que o sujeito se autoidentifique, parte-se do princípio, justamente, que esta demarcação identitária depende menos de um conjunto de critérios universais e mais de um modo de percepção e de identificação que depende de uma construção subjetiva, ligada aos afetos e ao reconhecimento de si perante um outro.

Afonso \& Rodrigues (2003), sobre o tema da determinação de quem seria ou não considerado negro no país de forma a estabelecer justamente os que seriam ou não contemplados pela reserva de vagas, apresenta duas definições sobre "ser negro". A primeira poderia ser explicada da seguinte forma:

(...) todo indivíduo de origem ou ascendência africana suscetível de ser discriminado por não corresponder, total ou parcialmente, aos cânones estéticos ocidentais, e cuja projeção de uma imagem inferior ou depreciada representa uma negação de reconhecimento igualitário, bem como a denegação de valor de uma identidade de grupo e de herança cultural e uma herança histórica que geram a exclusão e a opressão. (D'adesky, 2001: 34 in: Afonso \& Rodrigues, 2003: 283). 
A outra conceituação justificaria justamente o critério autodeclaração usado para inclusão dos estudantes no sistema de reserva de vagas, em função desta auto-afirmação perpassar sobretudo uma "posição política que o indivíduo adota diante da coletividade" (p.283). E como explicam os autores:

Ao dizer-se negro, mais que compartilhar traços fenotípicos como cor de pele, formato de nariz ou tipo de cabelo, o sujeito estaria assumindo a postura política de se ligar a um grupo historicamente discriminado negativamente, sofrendo de uma exclusão social e cujas origens históricas são depreciadas pelo grupo hegemônico. Esse posicionamento político traria a este sujeito a percepção de ser membro de uma coletividade que the assegura determinados direitos mas também encerram inúmeros ônus sociais, com os quais deveria arcar conscientemente. (p.283)

Tangente a esse debate, de outro modo, a pesquisa de Castro (2001) sobre construção de subjetividade de jovens de crianças na relação com a cidade contemporânea, analisa especificamente o modo como estes atores sociais percebem a convivência nestes espaços, fazendo referência às noções de identidade e de pertencimento como necessárias à condição de constituição da cidadania. Em se tratando do que constitui a "subjetividade brasileira", a autora discute a dificuldade de jovens e crianças identificarem-se uns com outros de modo a sentirem-se parte de uma mesma nação, uma vez que apresentam mais diferenças que aproximações, sobretudo quando situados em posições sócio-econômicas bastante distintas. Explica a autora que:

\begin{abstract}
A apreensão de uma nação e a identificação com ela constrói-se também no registro afetivo, nas camadas mais profundas, não conscientes, do sujeito a partir de múltiplas experiências onde crianças e jovens tem de enfrentar os conflitos e as provações da convivência com pessoas diferentes para então estabelecerem sua apreensão do que faz e como faz o brasileiro, brasileiro. Nascemos brasileiros apenas formalmente, mas tornamo-nos, de fato, brasileiros, como identidade coletiva, quando construímos paulatinamente através de nossas práticas cotidianas o sentimento de um povo, apesar das diferenças étnicas, sociais e culturais existentes.
\end{abstract}

Retomemos outra parte de seu discurso: "Eu não ouço isso mais porque eu só ando de moto, mas há um tempo atrás, eu só andava de ônibus. De eu tá dormindo, de tá acordado, e tá um monte de gente no ônibus e só eu ser pedido pra abrir mochila. E olha que eu não sou nem tão escuro assim! Só EU ser pedido pra abrir mochila! Só EU ser pedido pra ser revistado!”.

É no diálogo com as palavras de Castro (2001) que este estudante nos convoca à reflexão. Sua experiência na cidade urbana o leva a um entendimento de sua posição social e produz efeito de reflexo. O sentir-se negro não se explica 
nas nuances de seu tom de pele, mas nos modos como a sociedade o devolve 0 significado de "ser negro".

As contribuições de Cassab (2001) ilustram e dialogam com o discurso do estudante quando a mesma analisa que:

A cidade é, ainda, um 'outro', espelho que 'dialoga' com o sujeito na produção de si mesmo. A cidade favorece identificações, ela permite ao sujeito reconhecer-se, também, através da imagem que devolve. Para aqueles que trazem em seu corpo os signos visíveis de desvantagens no jogo de inserção social, a cidade é um espelho de alta reflexão. (p.210)

Soares (2004) analisando especificamente os conceitos de invisibilidade e de reconhecimento de jovens pobres na cidade, explica:

A identidade só existe no espelho, e esse espelho é o olhar dos outros, é o reconhecimento dos outros. É a generosidade dos outros que devolve nossa própria imagem ungida de valor, envolvida pela aura da significação humana, da qual a única prova é o reconhecimento alheio. (...) construir uma identidade é necessariamente um processo social, interativo, de que participa uma coletividade e que se dá no âmbito de uma cultura de um determinado momento histórico. (p.137)

As análises de Castro (2001) encorpam a discussão na medida em que apontam a cidade contemporânea como sendo o cenário no qual se tornam visíveis as desigualdades sociais. Isto aconteceria em razão da exibição permanente de signos visuais que demarcariam e diferenciariam os indivíduos quanto às suas posições e realidades sociais.

A mesma autora faz uma analogia entre a vivência do sujeito-citadino contemporâneo e o Flaneur, descrito por Walter Benjamin, como o grande conhecedor da cidade. Ambos - o homem contemporâneo e o Flaneur, de Benjamin -, consistiriam em fisionomistas da multidão, ou seja, leitores e decodificadores de rostos humanos, nos seus gestos, expressões e sinais, inferindo possíveis características e dados pessoais a partir destas decifrações. Explica a autora:

O reconhecimento e a identificação de "quem sou eu" e "quem é o outro" se apoiam nos processos dinâmicos de disponibilizar, ostentar e decodificar as particularidades visíveis que permitem localizar cada sujeito anônimo da grande cidade em termos de suas afiliações sociais, culturais e territoriais. (p.119)

As considerações precedentes fazem eco com um dos argumentos usados em defesa do critério racial como condição para reserva de vagas, quando parte do princípio de que o mesmo critério usado pela sociedade para discriminar de forma negativa os sujeitos - a cor da pele - passa a ser usado com a função de 
inclusão - a discriminação positiva, uma das premissas das políticas de ação afirmativa.

O que fica proeminente nas falas é a maneira como este tema atravessa as relações cotidianas na universidade, tal qual um reflexo do contexto urbano mais amplo, permeado por julgamentos, preconceitos e estereótipos.

As temáticas do preconceito e do racismo tomam a cena de forma mais contundente quando a imagem fotográfica a seguir denuncia uma suposta situação concreta de racismo envolvendo estudantes de um dos cursos da universidade e integrantes do movimento Denegrir, mencionados na imagemfotográfica anterior.

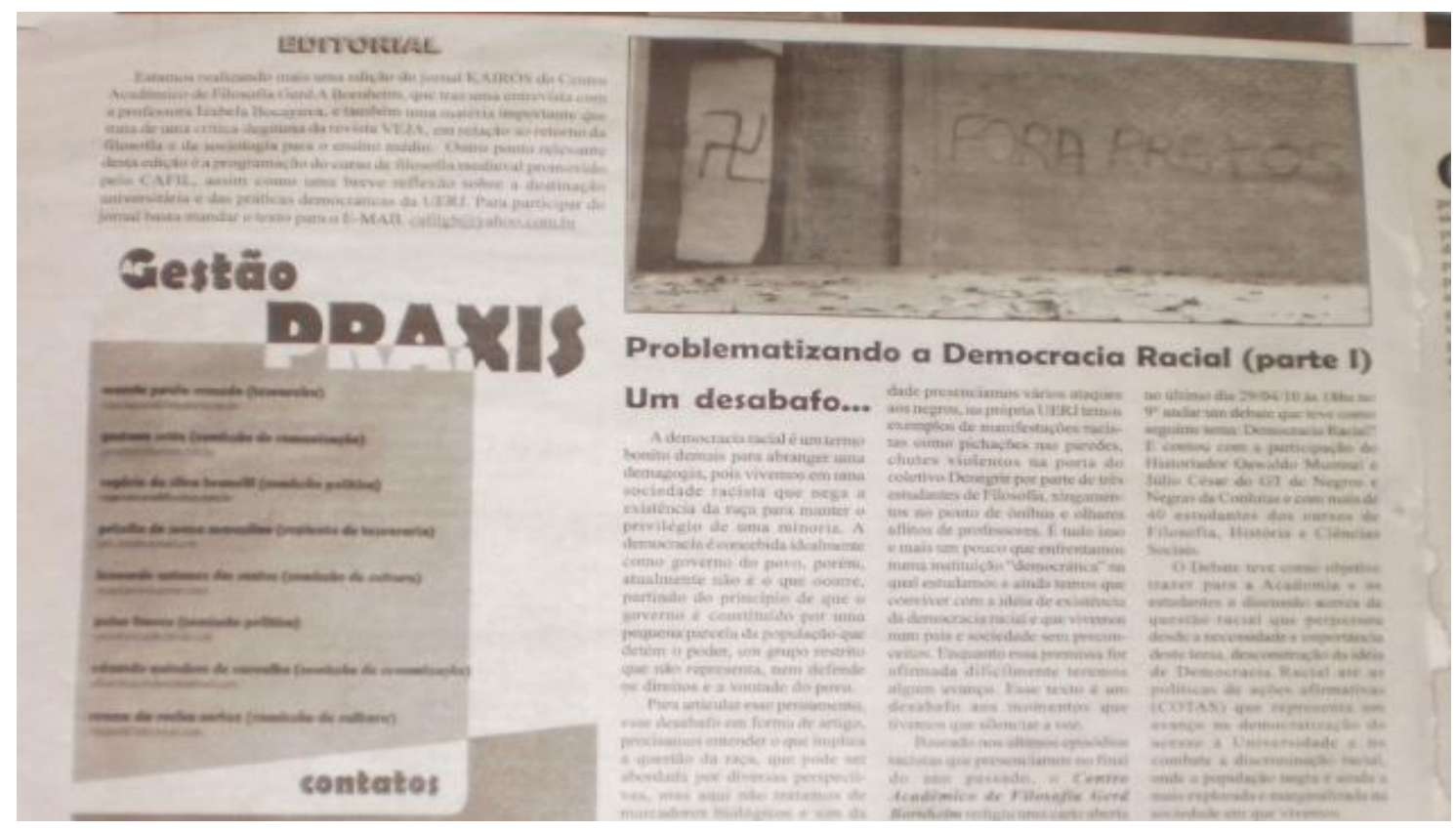

Foto - 75 - Jornal do CAFIL - Centro Acadêmico de Filosofia.

A fotografia, registrada no mural do Centro Acadêmico do Curso de Filosofia da UERJ foi publicizada em uma das edições do jornal do CAFIL (gestão práxis) e afixado no mural do curso. Trata-se de um artigo de título: "Problematizando a democracia racial", de autoria de um estudante do curso junto com uma imagem das paredes da UERJ "pichadas" com os dizeres "fora pretos", ao lado do desenho de uma suástica. Encontra-se abaixo subscrita parte do texto contido no jornal. Vejamos do que se trata:

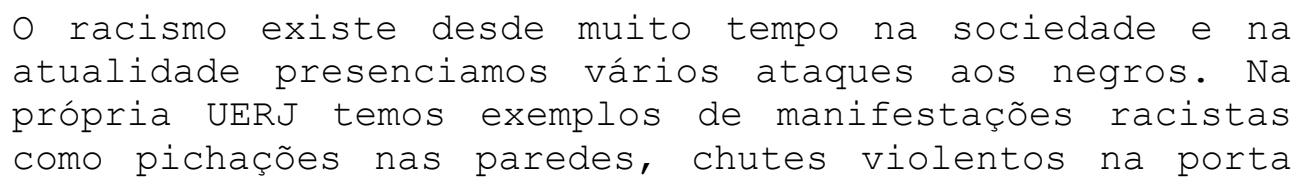


do coletivo Denegrir por parte de três estudantes de filosofia e xingamentos no ponto de ônibus e olhares aflitos de professores. É tudo isso e mais um pouco que enfrentamos numa instituição democrática na qual estudamos e ainda temos que conviver com a ideia de uma democracia racial e que vivemos num país e numa sociedade sem preconceitos. Enquanto essa premissa for afirmada dificilmente teremos um avanço. Esse texto é um desabafo dos momentos em que tivemos que silenciar a voz.(...) Baseado nos últimos episódios racistas que presenciados ano passado, o centro acadêmico de filosofia redigiu uma carta aberta a comunidade à UERJ repudiando ações realizadas por um grupo de estudantes de filosofia e demais casos de racismo tendo em vista a importância de combatermos no interior da universidade e em toda a sociedade o racismo e foi motivado por isso que o CAFIL realizou um debate (...) que teve como tema "Democracia racial"?! O debate teve como objetivo trazer para a academia e os estudantes a discussão acerca da questão racial que perpassou desde a necessidade e importância deste tema até as politicas de ações afirmativas (cotas) que representa um avanço na democratização do acesso e no combate a discriminação racial onde a população negra é ainda mias explorada e marginalizada na sociedade em que vivemos. Por fim o CAFIL se coloca na luta diária contra o racismo e em defesa das cotas.

$\mathrm{Na}$ apresentação da imagem-fotográfica, o texto, pouco visível, perde foco pra imagem que se situa acima dele. Esta imagem desencadeou reações e impactou os grupos, pondo em reflexão o tema do preconceito e o modo como este perpassa as relações sociais no Brasil. O fato ocorrido permeou as conversas e assumiu versões variadas, entremeadas por fatos, histórias e boatos. Muitos entrevistados não tinham tomado conhecimento do fato ocorrido, entrando em contato a partir da imagem, como se pode verificar no diálogo entre os estudantes e o pesquisador:

\footnotetext{
E1: Nossa! Não fiquei sabendo disso.

E2: Eu também não fiquei sabendo na época não.

E1: Isso é um tipo de coisa que pode acontecer.

E2: Isso é muito sério, não é?

E1: Mas num ambiente acadêmico isso pode acontecer.

P: Nunca viram nenhum tipo de incidente parecido? Nem dentro dos banheiros?

E1: Já vi muita chacota com homossexuais. Banheiro coisa assim. Mas uma suástica to vendo agora. (estudante)
}

Outros souberam do ocorrido e manifestaram suas versões:

Foi uma época que picharam a porta. Isso deu até polícia, pra falar a verdade. Pretos e o símbolo do nazismo ali do lado. 
Eu acho que as medidas foram tomadas. Eu tenho uma teoria. Principalmente quando a gente tem uma preocupação com essas questões críticas. Inflama ou você joga querosene no negócio o negocio vira... se você sabe lidar, dialogar com as questões, você apura. Não pode se omitir. Mas você intervém na medida certa. Acho que isso foi denunciado, foi aberto inquérito policial. Pra te falar a verdade ainda tá rolando alguma sindicância.

P: Isso foi uma situação pontual? Vocês não presenciaram escritos outros?

Pontual!

Eu nunca.

Você nem soube dessa história?

Eu nem soube.

Eu soube. Aí é o que eu digo. Dependendo do enfoque as pessoas podem pegar aquilo e transformar num incêndio, num fato. Realmente foi um fato. Aconteceu e tem que ser apurado. Não podemos dizer que não aconteceu. Aconteceu. Mas aquele fato tem diversas maneiras de ser visto. (funcionários)

CA de filosofia. É o um caso que aconteceu que picharam o banheiro. Teve uma festa no Centro Acadêmico, algumas pessoas chutaram a porta do Denegrir. Rolou uma pancadaria. Um cara passou a mão na bunda de uma menina do CA de filosofia e acabaram julgando como se tivesse feito isso. Essa foto foi inclusive tirada por um cara do CA de filosofia.

E encontraram as pessoas que fizeram isso?

Não, mas tiveram suspeitos.

Mas foi uma situação pontual, vocês acham? Vocês percebem alguma coisa parecida?

Não é nem isso, mas a forma como a pessoa age. Muito difícil gente aqui na universidade contra as cotas. É muito difícil essa pessoa se posicionar. Tipo assim: "eu, dentro do CA, sou contra as cotas". Até porque às vezes tem medo dentro uma universidade onde 50\% são cotistas, de chegar lá e mostrar: "Essa é minha posição e eu sou contra por isso e por isso. Ás vezes preferem agir dessa forma. Inclusive já teve caso de uma menina do serviço social ter sido chamada de macaca.

Aí quando ela foi na Delegacia não tinha como dar queixa porque não tinha nome do cara e endereço completo. (estudantes)

Incidentes assim mais de racismo exacerbado como esse do "Fora Pretos", teve um agora no começo do ano, não sei se você chegou a falar com o pessoal da engenharia química, mas deu uma discussão, acho que na internet, por causa das declarações do Bolsonaro. Teve até uma charge que o Latuff fez, depois desse incidente, que tem assim, uma pessoa matando como se fosse o nazismo, não sei se é uma arma ou uma cobra, não sei se você já viu essa charge. É uma charge recente do Latuff que ele fez em função disso. (estudante)

A entrevista a seguir traz certa peculiaridade nos discursos quando o tema desencadeado pelo acontecimento denunciado na imagem-fotográfica deflagra temas outros relativos a situações de preconceito e discriminação na cidade numa discussão marcada por relatos, boatos, histórias. 
E1: Ai que horror! Que isso?

E2: Foi aqui na UERJ em algum lugar.

E1: Faz tempo isso gente. Não acredito! Quem seria o retardado que ia fazer isso agora?

E3: É verdade! Eu lembro de uma história dessa. Nossa!

E1: Gente mas isso aí é coisa de gente com probleminha!

E3: E Foi 2009, 2010, comecinho de 2009. Tinha um debate muito grande sobre isso sim e foi quando tava acontecendo.

E1: Que coisa!

E4: A gente! O Colégio do Instituto de Educação tem uma sala nazista e ninguém bota isso. Fica embaixo do auditório. Quando foram encontrar fica embaixo da escadaria que você sobe em cima do auditório. Só que, quando foram fazer a reforma, descobriram que tem um buraco que era tampado e era utilizado como prisão no tempo da ditadura militar, que ele tinha cela. Ou era no tempo da ditadura militar ou talvez tenha sido utilizado no tempo de Getulio Vargas. Ontem foram cinco skinheads, acho que foi em são Paulo. Eles tavam querendo matar uma pessoa. Querendo matar uma pessoa porque? Porque é negra.

E3: E aqui no Brasil, o que fica mais ridículo ainda.

Engraçado que vira um estereótipo deles próprios e todos eles com cabeça raspada. (estudante)

E1: Acho que é falta de instrução.

E3: Que falta de instrução nada! Se você pegar Casa Grande e Senzala você vai ver que todo mundo teve um pé na áfrica!

E4: Que instrução o que! Se você for ver vai ver que tem um sanguezinho lá. Você matar achando que você é superior porque você não tem nenhum traço dele! No Brasil chega a ser burrice.

E2: Eu diria mais. É o auge da intolerância! No Brasil, até então, você não tinha o preconceito, tinha o preconceito de tudo, não só religioso, mas era uma coisa mais escondida.

E agora essa coisa. Tá usando a liberdade de expressão como forma de que eu posso falar que você não presta porque você é gay, porque você é pobre, porque você é negro ou porque você é nordestino. Porque, aqui no Rio não cai tanto, mas em são Paulo ser nordestino é sinônimo também de um perigo com relação a isso. Pra mim é o cúmulo da intolerância. Eu não acho que alguém nasce pra ser burro. Acho que é uma questão sócio-cultural. (estudantes)

Soares (2004) entende o preconceito e a indiferença como formas de tornar o sujeito invisível, como ato de violência, assim como disparadores da própria violência. Explica o autor:

Um jovem pobre e negro caminhando pelas ruas de uma grande cidade brasileira é um ser socialmente invisível. Há muitos modos de ser invisível e várias razões para sê-lo. No caso desse nosso personagem, a violência decorre principalmente do preconceito ou da indiferença. Uma das formas mais eficientes de tornar alguém invisível é projetar sobre ele ou ela um estigma, um preconceito. Quando o fazemos, anulamos a pessoa e só vemos o reflexo de nossa própria intolerância. Tudo aquilo que distingue a pessoa, tornando-a um indivíduo, tudo o que nela é singular desaparece. (p.132) 
Arendt (1998) analisa o preconceito e o boato e os distingue nos seus modos de operar e gêneses. Atribuindo ao preconceito o sentido de um julgamento a partir de um juízo já formado e "arrastado através dos tempos" (p.30), explica que:

A palavra julgar tem, em nosso uso idiomático, dois significados distintos um do outro por completo, que sempre confundimos quando falamos. Ela significa, por um lado, o subordinar do indivíduo e do particular a algo geral e universal, o medir normalizador com critérios nos quais se verifica o concreto e sobre os quais se decidirá. Em todos esses juízos encontra-se o preconceito; só o indivíduo é julgado, mas não o próprio critério nem sua adequabilidade para medir. (p.31)

De volta às entrevistas, as imagens a seguir também fizeram parte do conjunto final de fotografias nelas apresentadas. Estas, por sua vez, foram registradas na porta de entrada onde se localiza o Coletivo de Estudantes Denegrir, mencionado no artigo do Jornal do CAFIL. Os discursos dos entrevistados remetem a reflexões que delineiam o tema da política de cotas e marcam o debate sobre o tema, como identificação e pertencimento étnicoracial, a participação dos movimentos sociais na interface com a política de reserva de vagas e o racismo no Brasil. Ao que parece, uma rede de falatórios em torno dos modos de atuação do grupo transitam e circulam pela UERJ. Vejamos o que as imagens põem em discussão nas vozes dos sujeitos da pesquisa:
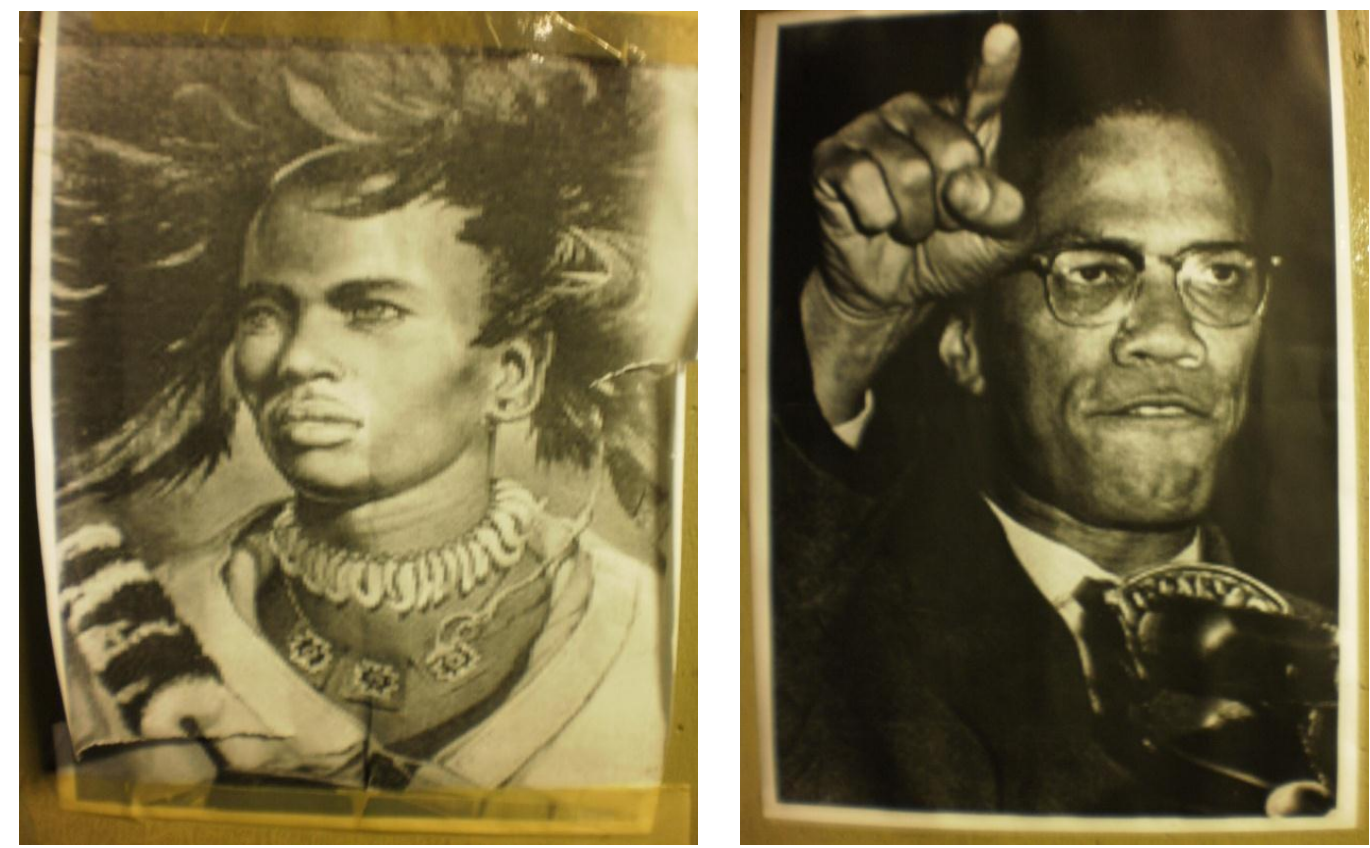

Fotos 76 e 77 - Entrada do Denegrir (Coletivo de estudantes negros da UERJ) 
E1: Isso fica na entrada daquele movimento negro que tem lá no andar de história.

E2: Não gosto desse movimento! Só pode entrar com o cabelo... se você passar "henê" no cabelo já era! Não gosto. Acho muito feio esse negócio de preconceito, tanto de uma parte quanto da outra.

P: Mas vocês já tiveram algum contato com alguém do grupo?

E1: Não. Só a porta. Eu sei que eles fazem festa e só deixam entrar mulher branca e homem branco não pode.

E1: Que?

E2: É

E1: Mentira!

E2: Verdade!

E1: Eu tenho uma amiga que durante um tempo foi do movimento e achava interessante. Ela achou eles um tanto radicais. Teve uma briga quando ela fez um relaxamento no cabelo e isso desencadeou para ela sair do grupo. Uma coisa tão pequena, o movimento, a ideologia é tão maior. (grupo de estudantes)

E1: Denegrir é um movimento negro que era muito ativo numa época. Só que ele acabou se fechando hoje. Hoje eles ficam numa sala fechada.

E2: Virou um grupo de estudos.

E3: Ninguém branco pode entrar na sala deles.

E2: Se entrar os brancos são expulsos.

E1: É. O debate deles são: os brancos são ruins e os negros sofreram opressão. Obviamente essa opressão foi feita pelos brancos, inclusive eles reivindicam que mulheres negras não podem se relacionar com homens brancos. Isso aconteceu com uma amiga minha.

P: E O contrário não?

E1: Não sei. Eu ouvir alguém contar uma história de um menino do Denegrir que namorava uma menina branca, mas ele separou dela e casou com uma menina negra por uma questão política. Mas é uma historia. Então não sei. (estudante)

E: O Denegrir é bem conhecido na faculdade por ser um grupo bem fechado, com características próprias. Inclusive racista, às vezes. Eu já ouvi pessoas que são do Denegrir fazendo crítica a quem é do denegrir por dizer que eles implementariam uma chamada "piguimentocracia", quer dizer, quanto mais negro melhor. Isso aí eu ouvi dizer de pessoas que são do movimento negro. Teve um menino aqui que não conseguiu entrar no Denegrir porque ele não foi considerado negro o suficiente.

P: Mas ele era negro?

$\mathrm{E}:$ Ele se reconhecia.

"Esse cara era um dos responsáveis por a gente tá numa posição hoje de ter condições de brigar, de discutir, de bater de frente. Porque ele é um cara que, na época dele, acho que ele era pior. Não sei também se era pior, naquela época era mais "escraxado", mas ele uniu e une até hoje gerações que tentam pensar táticas e estratégias diferentes. Não sei porque tem gente que ta dizendo que o denegrir tá tentando mudar alguma coisa, de pessoas que propõem a luta armada. Muitos viajam nesse sentido. Dizem que o denegrir tenta se colocar como vítima e que eles são racistas, só que em relação aos brancos. Mas, não é que eles sejam assim. Conheço muito gente de lá. Paro pra conversar com alguns, não com todos. Mas a realidade é que o racismo existe. E se você 
fala que o racismo existe, o negro pode concordar contigo, mas o branco não vai concordar e isso pode passar por uma outra discussão no sentido de que, o branco pode não só não concordar contigo como pode "meter a porrada", como bater na porta do Denegrir, como já aconteceu outro dia. (...) Quanto a outros assuntos, os caras são críticos. O cara tá se defendendo, ao mesmo tempo em que ele tá se defendendo, ele tá defendendo a galera dele, a tribo dele, tá defendendo os antepassados, que não parece não mas isso pega muito pra gente. Eu me coloco nesse lugar, compartilho com algumas ideias deles. É que nem se você pensar que você teria seu pai sofrendo e apanhando. Não tem como, com o passar dos anos, você não lembrar do sofrimento do seu pai. Então, a gente lembra dos sofrimentos principalmente dos antepassados. A galera pode achar: "isso é delirante, cara!" "Não é! Isso pra gente passa a ser quase que espiritual. É uma coisa que você vai dizer que pode não sentir, outras pessoas vão dizer que vão sentir e podem também não sentir. (estudante)

E eu não acho que o Denegrir seja esse "bicho-papão" que esse pessoal todo tá falando não. Têm umas pessoas como tem aqui fora. Aqui fora que eu digo que não seja do Denegrir. Toda vez que eu passo ali na frente a galera me chama. Tem quem diga que pro Denegrir eu sou branco, mas que isso não condiz com a realidade. Porque eu passo ali e os caras me chamam de irmão. Os caras me abraçam de um jeito, pessoas que ás vezes eu nunca vi. O cara pega: "me dá o braço aqui, irmão!" Os caras vêm e me dão um abraço. Eu acredito muito na questão de energia. O cara me trata bem, bem melhor do que qualquer outra pessoa, seja negro, seja branco, seja índio que olha pra tua cara e te ignora. Todo mundo acha que o Denegrir acha que eu sou branco, e me excluir porque acha que não sou negro, pelo contrário. (estudante)

Os trechos extraídos das falas de estudantes que fizeram parte da pesquisa denotam entendimentos variados desencadeados por imagens que fazem referência ao grupo representado. As diferentes opiniões sobre a atuação de um dos movimentos organizados de estudantes militantes negros na UERJ sinalizam uma "rede de falatórios" desencadeada pela presença do grupo ${ }^{70}$. $\mathrm{O}$ que sobressalta desta "rede de falatórios" é a eminência da discussão do racismo e as formas de combate e de enfrentamento do tema no interior dos movimentos sociais militantes, permeando o interior na universidade e as

\footnotetext{
${ }^{70}$ Vale esclarecer que, durante a pesquisa, houve tentativas de contato com o grupo Denegrir, entretanto, sem êxito. Após uma breve investigação dos significados das imagens, vale um breve histórico da trajetória do líder Malcom X: "Enquanto Martin Luther King apostava em uma resistência pacífica como arma para enfrentar o racismo, Malcolm X defendia a separação das raças, a independência econômica e a criação de um Estado autônomo para os negros. Ao lado de Elijah Muhammed, viaja pelos principais estados norte-americanos para pregar as suas idéias e defender a libertação dos negros". (biografia Malcom X - educação UOL)
} 
relações entre os grupos entremeadas por afiliações, por um lado, e "desidentificações", por outro.

Analisando mais detidamente os discursos na interface com as imagensfotográficas apresentadas, sobretudo as que se relacionam com a questão racial no Brasil, assunto de maior repercussão na implementação da política de reserva de vagas na UERJ e nas demais instituições de ensino superior pioneiras, pode-se notar que a implementação da política fez provocar no cotidiano da universidade debates de temas que acometem as experiências dos sujeitos na cidade mais amplamente e se refletem no interior da instituição. Os movimentos sociais, especialmente os grupos militantes do movimento negro, vêm se fazendo presentes e são, em muito, responsáveis pela consolidação da proposta nas universidades. Contudo, a presença de um grupo específico na UERJ, independentemente das ações corresponderem aos comentários que sobre eles versam ${ }^{71}$, reverbera reflexões e posicionamentos sobre identificações étnicas no Brasil, tangencia as polêmicas sobre a miscigenação racial, argumento frequentemente usado para deslegitimar a política de cotas raciais e que serve de subsídio para embasar a argumentação também em desfavor das cotas raciais de que a identificação étnica exigida pelo sistema acentua o racismo na sociedade, ao contrário de promover sua erradicação.

Em se tratando do debate sobre as cotas, tanto no que se refere aos posicionamentos favoráveis ou contrários quanto no que diz respeito aos critérios de seleção, este parece ainda dividir opiniões. Os discursos sinalizam que, ainda hoje, mesmo que mais timidamente, as tensões permanecem. É o que a pergunta feita na imagem-fotográfica a seguir faz suscitar:

\footnotetext{
${ }^{71}$ A proposta de fazer referência ao grupo neste trabalho na tem como principio uma avaliação e/ou julgamento de suas ações, principalmente levando-se em conta que seus depoimentos não fizeram parte da pesquisa, mas de analisar os efeitos que as imagens expostas pelo grupo nos corredores da UERJ provocam nos sujeitos que por ali transitam e quais a relações entre estas imagens e a discussão mais ampla sobre o tema das cotas raciais que podem ser vislumbradas nos discursos dos entrevistados.
} 


\title{
Pergunta feita no VI Censo:
}

\section{Na UERJ, a política de reserva de vagas tornou-se realidade, desde 2003 . Você considera que essa política reduz desigualdades sociais, étnico-raciais, econômicas, educacionais? \\ ( ) Sim \\ ( ) Não}

Foto 78 - "VI Censo UERJ_Política de reserva de vagas reduz desigualdades?"

\begin{abstract}
Abaixo, algumas das opiniões dos interlocutores da pesquisa:
E: A desigualdade social é muito ligada à desigualdade econômica. Acho que a parte socioeconômica não pode ser separada. De maneira alguma a política de cota racial favorece alguma coisa à desigualdade social. Pelo contrário. Você tá segregando, separando as pessoas por nada, por uma etnia, por uma coisa que nem existe mais no nosso país. Então, passa muito longe de agregar alguma coisa à igualdade social. (estudante)

Sim. Acredito, em parte. Obviamente que têm alunos que chegaram aqui e não tiveram a mesma educação que as outras pessoas. Que tiveram uma educação melhor. Mas esses alunos vão passar pelos mesmos professores, pelas mesmas obrigações. Se eles se formarem, vão ter as mesmas aptidões que qualquer outro aluno na universidade. Então ajuda muito a quebrar essas fronteiras. (funcionário)
\end{abstract}

"Sofrer uma experiência", como diz Castro (2001), significa permitir a "vivência do conflito, da dor e quem sabe, da reparação". (p.124) A questão do VI Censo, aqui subscrita e apresentada aos interlocutores da pesquisa, remetenos a reflexões sobre os efeitos da convivência cotidiana entre sujeitos diferentes no espaço da cidade contemporânea. Antes disso, o conceito de cidadania vem novamente á tona, na medida em que se entende por cidade um espaço mais do que meramente físico, um espaço praticado. "A cidade aqui é entendida não apenas como espaço físico ou construído, mas, sobretudo, como espaço social, já que as relações sociais tanto são moldadas como também moldam a materialidade do espaço físico", afirma Castro (2001). 
É possível argumentar sobre os efeitos promissores da convivência entre sujeitos de culturas e realidades distintas, tomando por base a analise da construção subjetiva de crianças e jovens, na pesquisa de Castro (2001) quando a mesma assevera:

As desigualdades sociais, apenas indicadas pelas diferenças sociais, podem ser elaboradas a partir de uma relação social ativa entre sujeitos diferenciados. Por exemplo, quando estes podem brincar juntos na escola, ou no parque, ou quando jovens de diferentes estratos sociais podem dançar ou se misturar no mesmo baile. Nestas situações, crianças e jovens são confrontados com fronteiras mais móveis - e potencialmente conflituosas - de identidade e diferença que devem ser negociadas e re-significadas no curso de suas trocas sociais. (p.127)

A pesquisa feita por Barcellos (2007) sobre a experiência de jovens de précomunitários na PUC-Rio, já antes mencionada, aborda as táticas de confronto e de negociação entre os estudantes das classes populares e das elites (maioria no caso específico da PUC-Rio, cenário daquela investigação). Uma das considerações feitas, a partir das análises do material da pesquisa na PUC-Rio e que podem dialogar com a discussão presente, pode ser retomada no trecho:

\footnotetext{
As realidades são diferentes e isto é um fato. A todo tempo os estudantes lembram-se: - lembram-nos com suas palavras -, o quanto as diferenças entre as realidades sociais e culturais são díspares. Estas diferenças vão desde o poder aquisitivo, incluindo neste quesito indiretamente os locais de circulação e consumo na Universidade e na cidade, as prioridades, até os valores e modos de ação/participação. Mas, também, certos jovens nos trazem relatos de aproximações, dando indícios de que a interação é possível, apesar destas diferenças. (p.160)
}

A discussão sobre a interação social entre os estudantes de diferentes contextos e culturas na universidade atravessada pelo que a política de reserva de vagas fez promover, especialmente nestas e noutras relações, serão analisadas mais detidamente adiante. Por ora, situemos as análises nos modos de construção da subjetividade na relação com a cidade. Cidade e universidade: linhas fronteiriças pontilhadas: é o tema que a próxima imagem-fotográfica faz eclodir. 


\subsubsection{A universidade na cidade e a cidade na universidade}

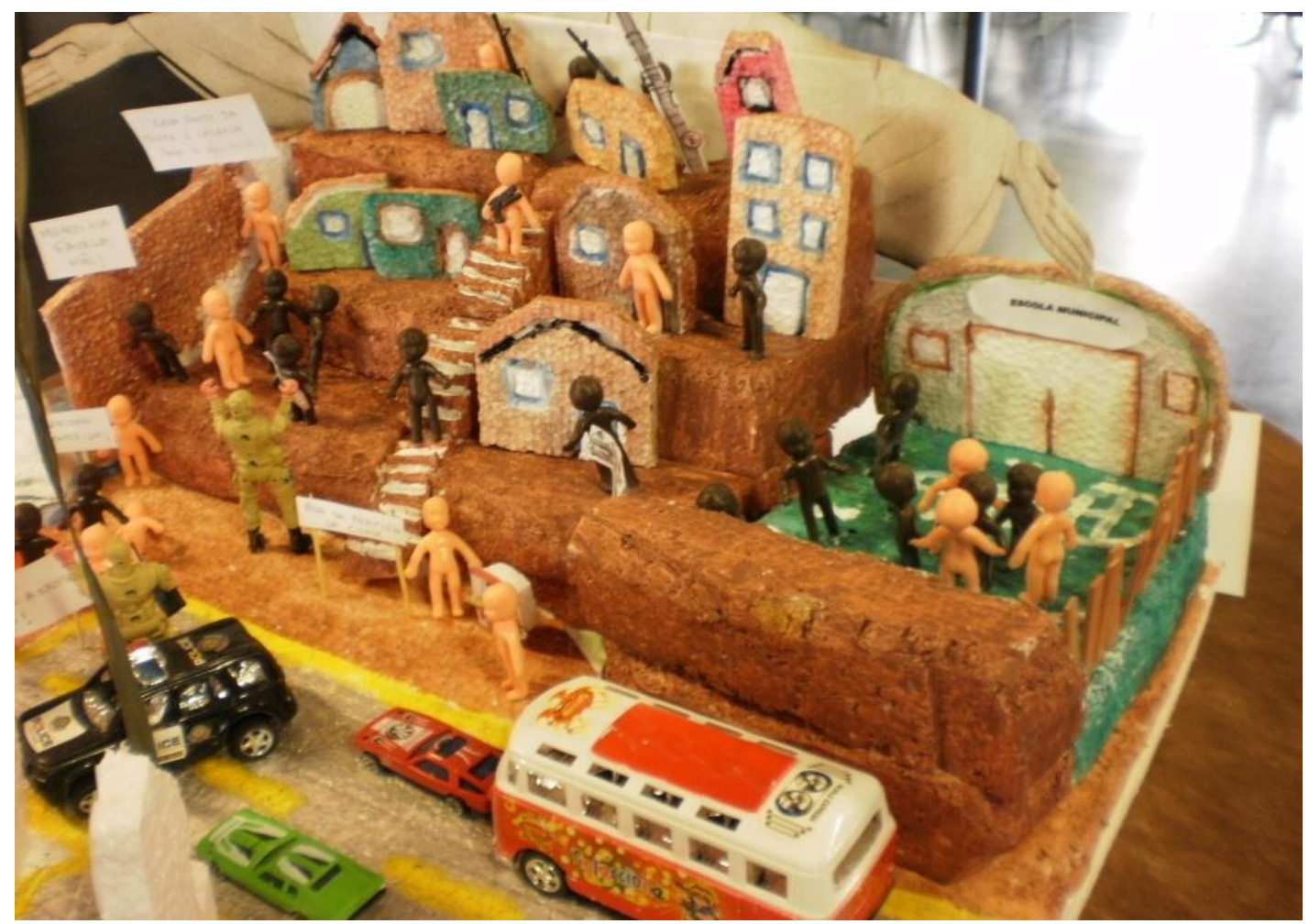

Foto 79 -"Arte, Cultura e Ciências Sociais_ A Cidade na Universidade."

O entendimento de "universidade" como: "Uma instituição social que exprime e reflete, de modo historicamente determinado, a sociedade em que está inserida". (p.30) agregadas às palavras de Chauí (in: Duarte e Rampinelli, 2005) que a conceituam como "uma instituição eminentemente política, em cujo interior 'reaparecem divisões sociais, diferenças políticas e projetos culturais distintos" (p.26) dialoga com os discursos dos sujeitos da pesquisa.

A imagem-fotográfica acima se refere a uma maquete feita por um estudante do curso de ciências sociais e exposta, no hall, durante a Semana de Artes, Política e Ciências Sociais na UERJ.

O que se faz notar, através dos discursos e dos debates desencadeados pela referida imagem-fotográfica, é que as linhas divisórias entre universidade e cidade são como linhas "pontilhadas", uma vez que através delas há um intercâmbio entre as práticas cotidianas na cidade e as relações sociais intramuros da universidade. 
Há que se enfatizar, sobretudo, a polissemia que a imagem é capaz de denotar, fazendo emergir temas afetos às relações sociais na cidade, sob distintas perspectivas.

Os sentidos e interpretações foram vários, como os destacados abaixo:

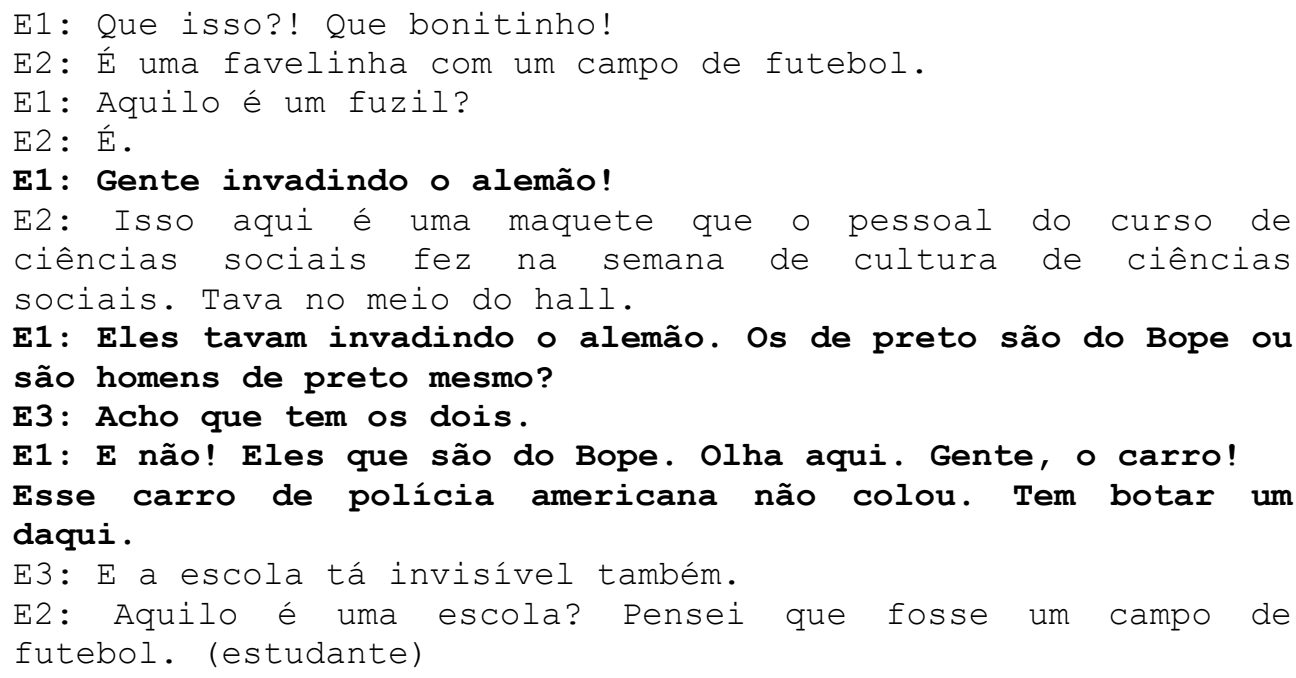

A quantidade de bonequinho negro em relação ao bonequinho branco. Onde é a maioria das escolas municipais de péssima qualidade hoje? Na favela. Na favela tem mais negro. Tem branco também, mas tem mais negro. Embora tenha mais negro tem branco também que necessita, tem uma condição econômica desfavorável. Tem que ser pensada uma nova política pra esse público também. (estudante)

Bacana. É favela, é isso? A primeira coisa que me chamou a atenção foi o branquinho branco com a arma. Não é porque é negro que vai ser bandido. (estudante)

O diálogo a seguir faz uma analogia direta com a cidade urbana, representada pela maquete ilustrativa, e a relação entre a UERJ e a cidade ao redor, enfatizando inclusive a característica que marca a cidade do Rio de Janeiro que aproxima favela e asfalto e ao mesmo tempo distancia em função dos modos de organização sociais e estruturais.

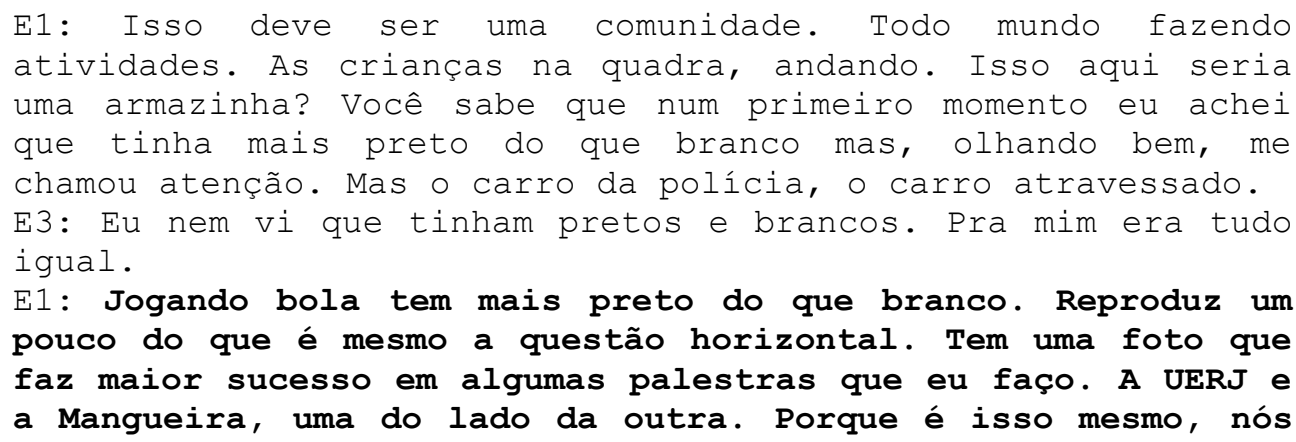
atividades. As crianças na quadra, andando. Isso aqui seria uma armazinha? Você sabe que num primeiro momento eu achei que tinha mais preto do que branco mas, olhando bem, me chamou atenção. Mas o carro da polícia, o carro atravessado. E3: Eu nem vi que tinham pretos e brancos. Pra mim era tudo igual.

E1: Jogando bola tem mais preto do que branco. Reproduz um pouco do que é mesmo a questão horizontal. Tem uma foto que faz maior sucesso em algumas palestras que eu faço. A UERJ e a Mangueira, uma do lado da outra. Porque é isso mesmo, nós 
somos tão próximos e tão distantes. Eu acho que a gente podia fazer alguma coisa mais. A gente já andou fazendo um trabalho no morro dos macacos, mas é difícil. (funcionário/professor)

Da mesma forma que a maquete faz emergir os conflitos e as relações experienciados dentro e fora dos muros da instituição, outros atores sociais - da comunidade externa - fazem sentir sua presença na universidade, trazendo pra dentro dos arredores do campus temáticas que, intramuros da UERJ, são experienciados de modos particulares.

Há, portanto, extensões da rede de agenciamentos em fluxo dentro do campus da UERJ para fora de seus contornos. A universidade e a cidade dialogam e se relacionam, sendo a primeira um microcosmo da segunda.

\subsubsection{A) Com a palavra: Os estudantes da rede pública de ensino de base}

A discussão sobre o racismo que, ganha escopo com os movimentos sociais organizados, particularmente o movimento negro, e que está intrinsecamente relacionado com o tema do sistema de reserva de vagas com critério racial na universidade, traz para o diálogo diferentes instâncias educacionais. O debate avança os limites extramuros da universidade, ou, melhor dizendo, se origina nestes espaços externos e invade a universidade. Com a palavra: os estudantes e profissionais da rede pública de ensino de base.

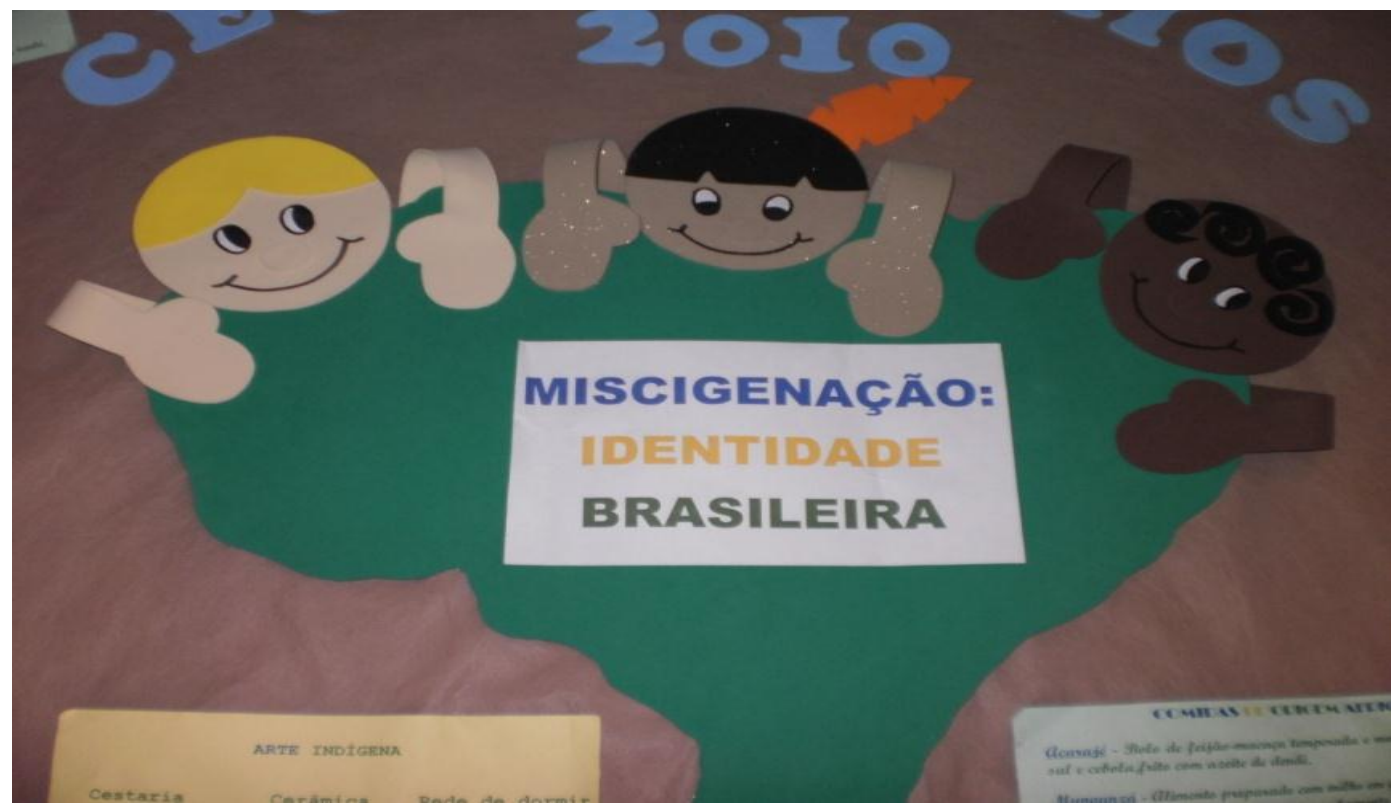

Foto 80 - cartaz feito por alunos do ensino público de base - RJ 
O evento que articula "racismo e educação" traz alunos da rede pública de ensino pro interior da UERJ e toma os corredores com a exposição de trabalhos sobre a temática do racismo no Brasil. Como parte do roteiro de imagensfotográficas apresentadas nas entrevistas foi incluída a fotografia seguinte:

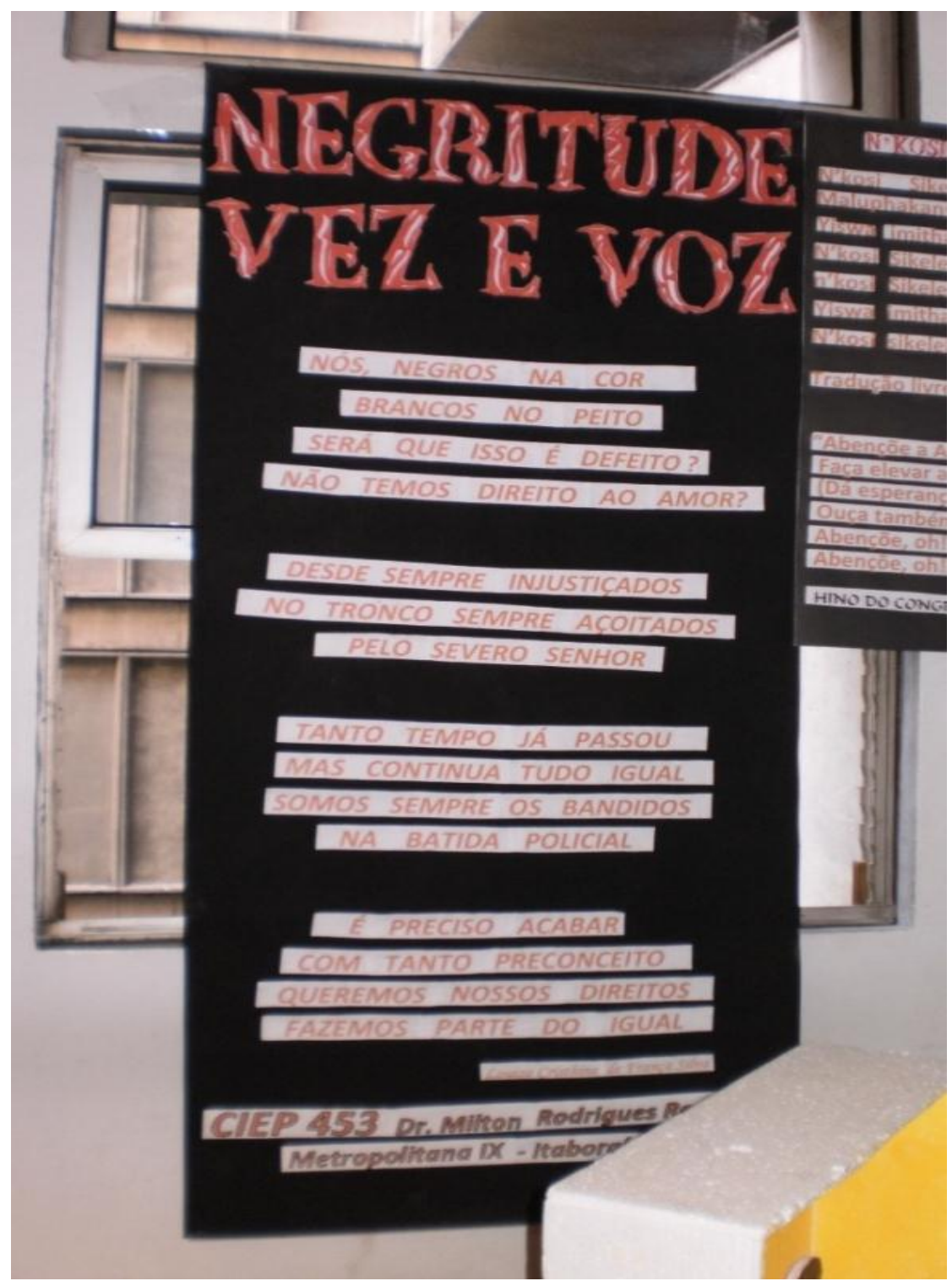

Foto 81 - "Escola e Universidade. Cartaz CIEP 453_: Negritude e Voz".

Um poema de estudantes de um CIEP localizado na região metropolitana do Rio de Janeiro provoca reação por parte de um dos entrevistados quando se depara com os dizeres: "nós, negros na cor, brancos no peito, será que isso é defeito?". A frase que, ao que tudo indica, estaria fazendo referência ao chamado "negro de alma branca", expressão tão amplamente combatida e criticada por ativistas do movimento negro, por pesquisadores dentre outros, 
passou despercebida por quase todos os entrevistados, com exceção de um deles:

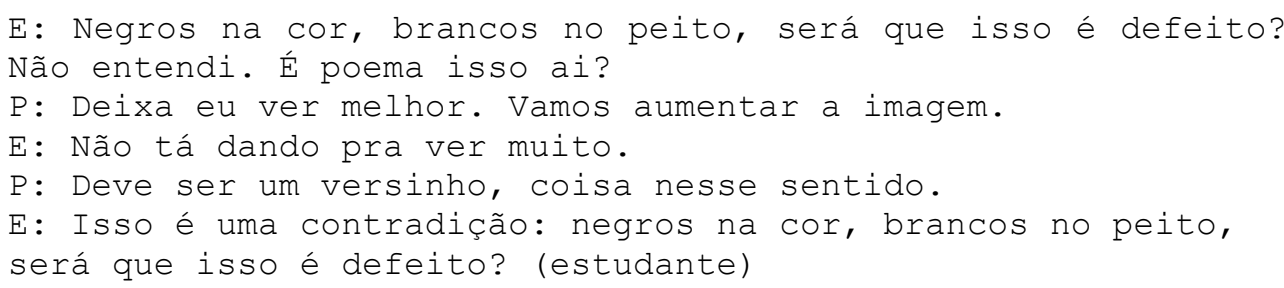

\subsubsection{B) As vozes dos candidatos e dos partidos: 0 processo eleitoral brasileiro}

Retomando o diário de bordo fotográfico como material de análise, na interface com os discursos oriundos das entrevistas feitas com o elenco restrito de imagens, há que se destacar, neste momento alguns acontecimentos/eventos que refletem esta dimensão dialógica e a rede de agenciamentos que interconecta cidade e universidade. A Universidade pública, pois, se configura pela tríade ensino, pesquisa e extensão e esta se presentifica nos vários acontecimentos da cidade que adentram os espaços internos e evocam nos seus atores sociais as relações e conflitos que permeiam o cotidiano dos sujeitos da cidade. Nesta rede de ramificações e interconecções entre as vozes extra e intramuros da UERJ, outro acontecimento afeta as configurações estéticopolíticas da universidade. Com a vez, o processo eleitoral brasileiro.

Em período pré-eleitoral brasileiro, as campanhas dos partidos e candidatos, com suas propostas e projetos políticos, interceptam os sujeitos com seus cartazes e com pautas eleitoreiras. As pautas e agendas de campanha que circulam na UERJ se endereçam para os interesses de públicos-alvo específicos, como os estudantes, professores, outros. 

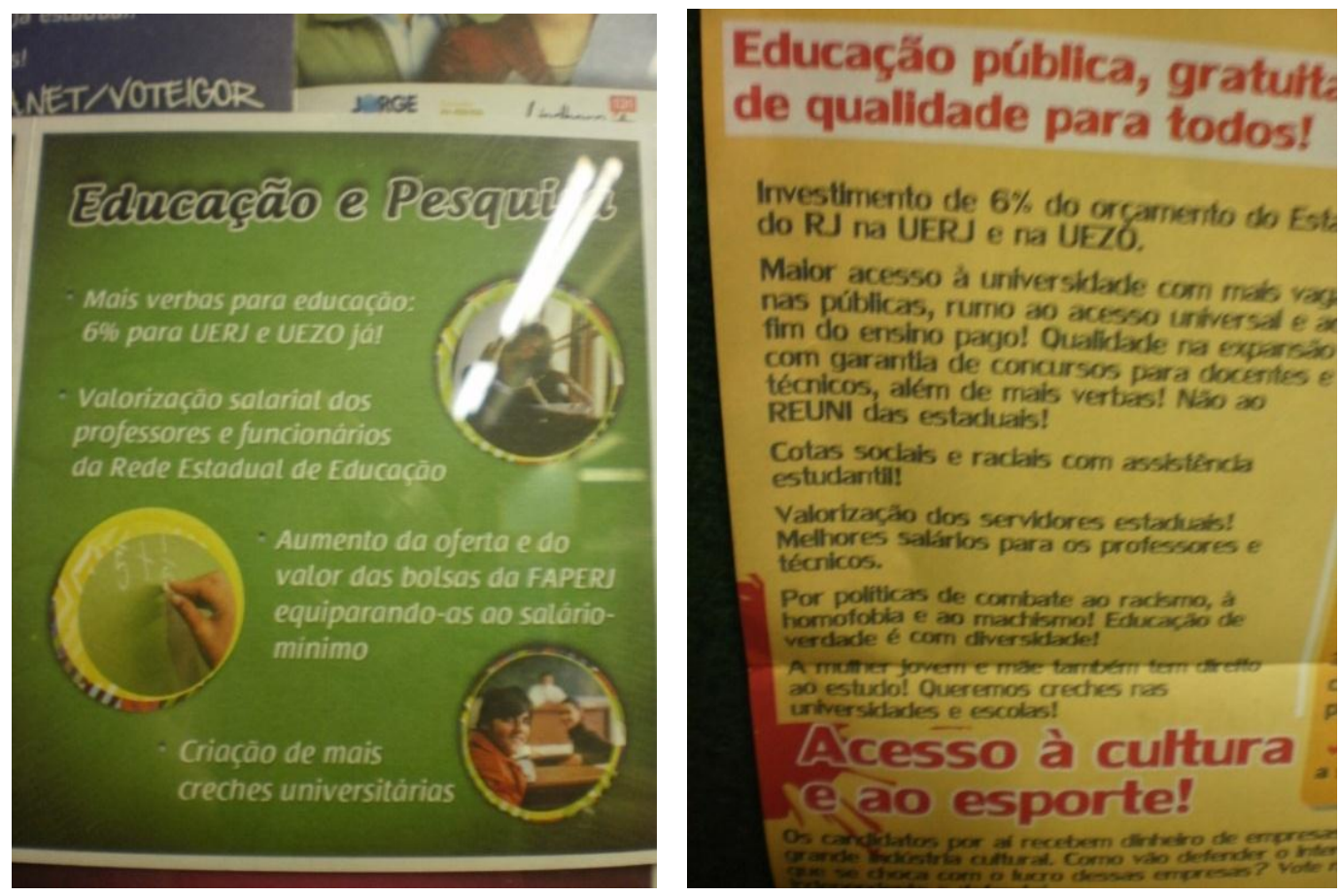

Fotos 82 e 83 - Jornais de partidos políticos

A política de assistência estudantil, há tempos almejada, ganha expressão e visibilidade nas plataformas políticas de alguns partidos, ao mesmo tempo em que, logo após o finalizar do processo, pode-se verificar um desaparecimento gradativo do tema das cotas nas discussões e nos materiais de campanha de maior circulação, dando lugar a temas de maior repercussão social, a exemplo do grande número de debates na universidade - durante o período das eleições e pós-processo eleitorial - sobre as UPPs (Unidades de Polícia Pacificadora), implementadas nas favelas cariocas, como alternativa de combate à criminalidade e ao tráfico de drogas nestes locais.

\subsubsection{C) As vozes da resistência: As tensões nas Universidades Federais e o tema das cotas}

O debate sobre sistema de reserva de vagas circula pela instituição através da entrada de instâncias externas à UERJ, a exemplo das escolas da rede públicas na vozes dos estudantes e dos partidos políticos e candidatos em processo eleitoral no país, com ênfase para as políticas de assistência estudantil, como já abordado. Contudo, ao debate sobre as cotas, propriamente dito, se no interior da universidade se reconfigura se apresentando segundo novos formatos, em função da consolidação da politica, nos espaços extramuros 
da UERJ as tensões permanecem mais acirradas. É o que faz parecer o jornal afixado num dos murais institucionais que veicula a seguinte nota:

\section{Cotas na federal} do Rio

OConselho Universitário da

UFRJ estuda a implantação das cotas na universidade. A reitoria apresentou proposta que garante $50 \%$ das vagas oferecidas em cada curso aos candidatos selecionados pelo Exame Nacional do Ensino Médio (Enem). Vinte por cento destas, em cada curso, seriam destinados aos estudantes cuja renda familiar per capita não seja maior do que um salário mínimo. A proposta deve ser apreciada e deliberada até agosto, quando deverá ser publicado o edital do vestibular 2011.

Foto 84 - Informe Asduperj

A polêmica em torno da implementação do sistema de reserva de vagas em outras universidades, cuja proposta ainda não foi consolidada, caso das Universidades Federais do Rio de Janeiro, ganha os murais da UERJ fazendo permanecer vivo o debate sobre o tema, mesmo após 10 anos de experiências em várias instituições de ensino superior do país.

\subsubsection{D). Os cursos pré-vestibulares comunitários no diálogo e as ramificações para dentro dos muros da UERJ}

A atuação dos cursos pré-vestibulares comunitários, com participação expressiva na concretização da política de reserva de vagas no ensino superior brasileiro, também faz notar sua presença através de cartazes nos murais da 
instituição. Dentre vários, dois merecem destaque especial. Suas fotografias foram parte do acervo das entrevistas e desencadearam discursos importantes que ressaltam a participação destes movimentos e seus atravessamentos com as

UERJ.

\section{$\underline{\text { Venha dar aulas no pré-vestibular comunitário da UNIRIO }}$}

O Pré-Vestibular Comunitário da UNIRIO que funciona no curso de Direito em Botafogo - Voluntários da Pátria, 107 - está precisando de ajuda. Estamos recolhendo currículos de pessoas interessadas em lecionar gratuitamente, no ano de 2011, para estudantes de comunidades próximas da área em que o pré funciona.

Nosso projeto tem por princípio cooperar com a mudança social através de uma educação voltada para a inclusão e para a construção de uma cultura crítica tanto nos estudantes que venham a integrar o corpo de nossas instituições de ensino superior quanto nos educadores que se proponham a participar do projeto. Isso só é possível através de uma constante troca e aprendizado por ambas as partes.

Foto 85 - "Pré-vestibular comunitário UNIRIO: mudança social pela educação"

Um dos entrevistados identifica o cartaz acima exposto e diz ter sido o responsável por afixá-lo em um dos murais.

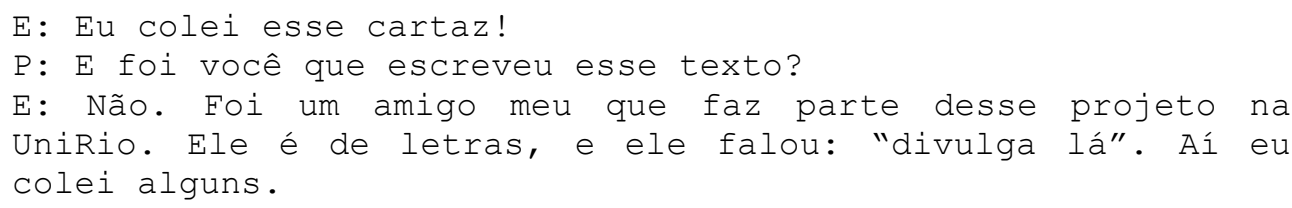

A atuação dos movimentos sociais organizados - movimento negro e cursos pré-vestibulares comunitários - se visibiliza dentro da UERJ. No caso específico dos cursos pré-vestibulares comunitários, não apenas alguns cursos convocam os estudantes da universidade a participarem, como fica nítido no cartaz anterior, como dentro da própria universidade, funciona um curso nestes moldes, vinculado ao sindicato dos servidores da UERJ: o pré-vestibular comunitário da UERJ. 


\section{Pre-vestibular do Sintuperj realiza Seminário}

O pré-vestibular comunitario do Sintu-

perj organizara, no dia 04 de dezembro, a

partir das 9 h 30 mais um seminario de balan-

codas atividades corganizaça do ano 2011 .

Oevento acontecera na sede do sindicato.

Segundoa coordenadora de formaçao, Fa

tima Diniz, oseminario e o momento em que

slofeitas avaliacoes dos trabalhos realizados. identificados os erros e acertos, e apontadas as perspectivas para o ano seguinte. Nesse ano, havera participacto de membros de outros prés vestibulares comunitarios para promover atrocade experiencias, Oobjetio campliar odcbate politico sobrea importan cia deste tipo de projetos no atual contexto socio cconomico brasilcino.

Foto 86 - Pré-Vestibular Comunitário do Sintuperj- UERJ

\subsubsection{E) A UERJ sem muros}

Falar em UERJ implica em considerar sua extensão territorial para além dos muros do campus maracanã. Vale lembrar, portanto, que a UERJ não se restringe ao este campus central - espaço de investigação desta pesquisa. A presença de trabalhos sobre o tema da política de reserva de vagas na "UERJ sem muros", por parte de grupo de pesquisa coordenado por professores e tendo por pesquisadores estudantes da UERJ provenientes de outros campi é bastante elucidativa. Faz lembrar as declarações feitas pelo PROINICIAR sobre os tentáculos deste programa para estes espaços e as estratégias de contemplar os demais estudantes na política de assistência estudantil, sediada no prédio central da universidade, na cidade do Rio de Janeiro.

A importância da interlocução entre os diferentes campi e de uma política de assistência estudantil que contemple os estudantes das várias UERJs, aparece no evento da "UERJ sem MUROS", sentido este que se reflete no próprio titulo do evento, que denota a dimensão intercambiante e dialógica que caracteriza as práticas cotidianas e as experiências dos atores sociais nesta instituição. 


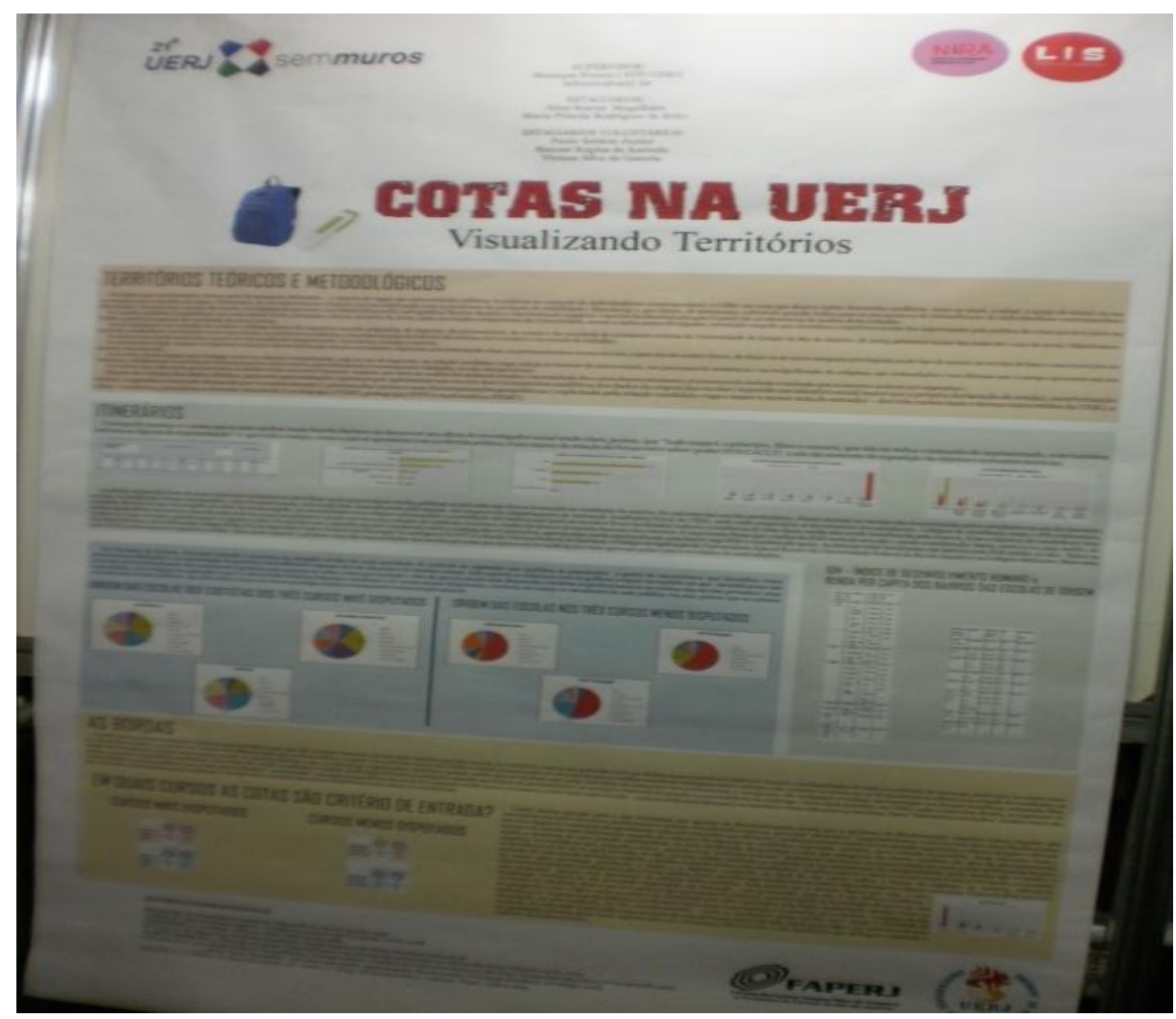

Foto 87 - banner em exposição na UERJ sem muros

\subsubsection{F) Arte e militância as charges do cartunista Latuff}

Analisando novamente as imagens que foram postas em diálogo com os entrevistados, partindo de uma dimensão dialógica que inclui não somente os sujeitos presentes no acontecimento da entrevista - pesquisador e sujeitos da pesquisa - mas os interlocutores das imagens, ou seja, seus autores, vale dar relevo a uma das imagens já apresentadas, conferindo destaque, desta vez, ao autor desta imagem com presença marcante nas campanhas eleitorais dos movimentos estudantis na universidade. 


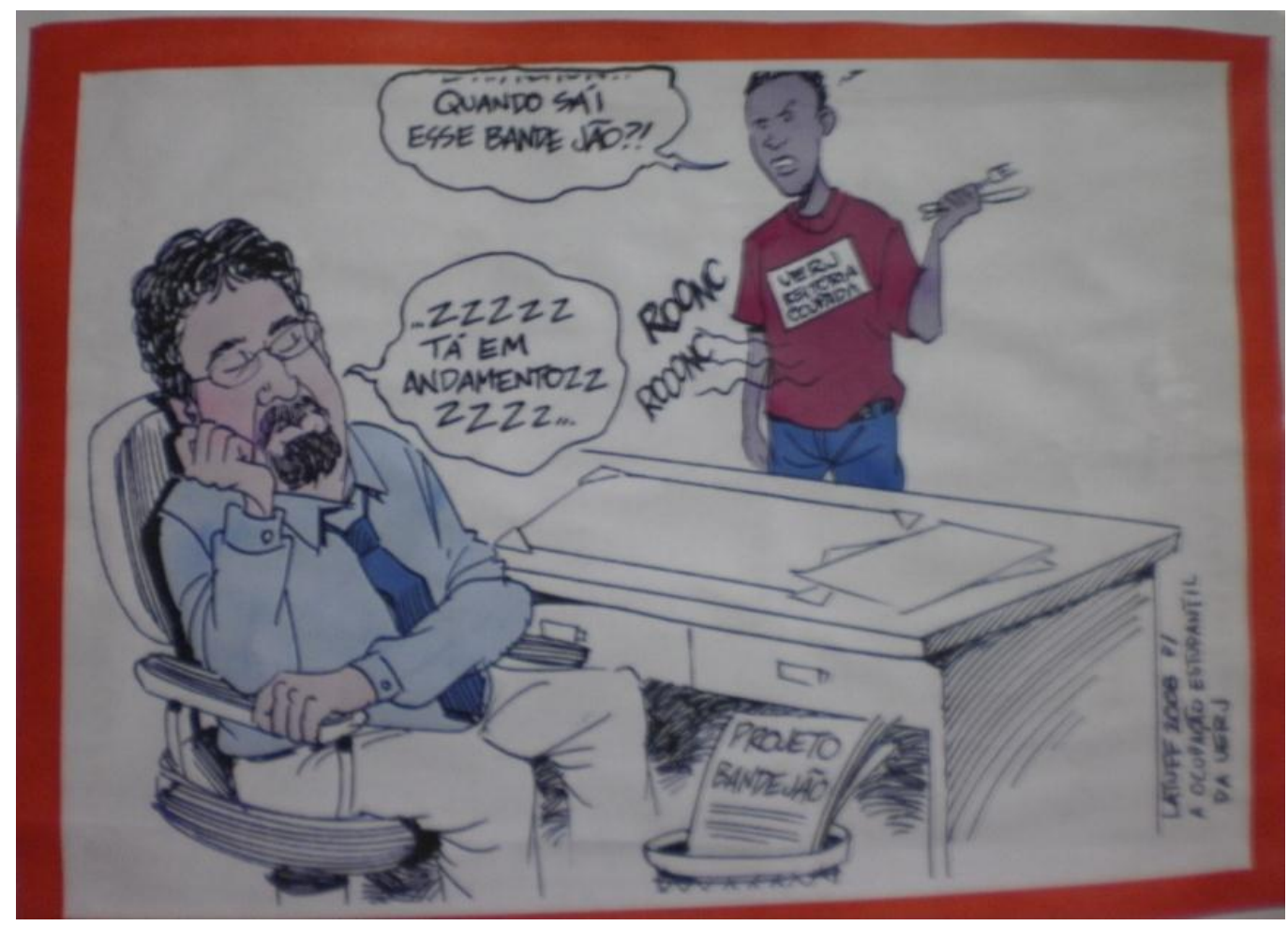

Foto 88 - Processo eleitoral/CAs - charge de C. Latuff

A participação das charges de autoria do cartunista Carlos Latuff ${ }^{72}$, reflete as alianças entre os grupos militantes organizados, especialmente dos estudantes, em articulação com ativistas políticos externos à UERJ, apontando uma grande arena política mais ampla que permeia a universidade e que, ao mesmo tempo, não fica a ela restrita.

Em meio a cartazes de partidos políticos, cursos pré-vestibulares comunitários, profissionais e estudantes do ensino público de base, ativistas e artistas-militantes, dentre vários outros atores, os murais de algumas áreas de formação específicas visibilizam várias outras vozes.

Os discursos dos entrevistados trazem questões desencadeadas pelas imagens-fotográficas que, por sua vez, apontam para temas que, apesar de não fazerem parte do acervo final de fotos, estão presentes no acervo maior de

\footnotetext{
72 "Carlos Latuff é da cidade do Rio de Janeiro nascido em 30 de novembro de 1968. É chargista, ativista. Iniciou sua carreira em agência de propaganda em 1989, quando sua veia artística floresceu para charges ao fazer em 1990, seu primeiro trabalho político para o Sindicato dos Estivadores, em um de seus trabalhos junto aos sindicatos. Com a explosão da internet e a facilidade de comunicação alternativa, Latuff encontra neste veículo, liberdade e incentivo para militar pelas causas dos excluídos e discriminados, Faz charges denunciando corrupção, violência, racismo, discriminações em geral. Trabalhou com o movimento zapatista que foi o que deu início a seu ativismo internacional. Em 1999 visita a Cisjordânia a convite de uma organização civil que viu um de seus desenhos na internet, ao conhecer em loco um dos assentamentos na faixa de Gaza, torna-se defensor da causa, dedicando seu trabalho a denunciar os abusos sofridos pelos palestinos. Artista engajado, ativista, Latuff é reconhecido dentro e fora do Brasil tendo sido o primeiro brasileiro a ter charges publicadas na Casa de Caricatura do Irã". Trecho extraído de: http://redeliberdade.blogspot.com.br/2010/11/carlos-latuff.html.
} 
fotografias pesquisa. O mesmo ocorre quando um dos entrevistados faz menção às parcerias de um dos cursos considerados mais elitizados da UERJ com agências de intercâmbio para países estrangeiros. Vejamos o conteúdo trazido nas imagens a seguir ${ }^{73}$ :

A Faculdade de Direito da UERJ, preocupada em compartilhar informações, formar laços de amizade entre os seus alunos e os de outras escolas e, assim, contribuir para o desenvolvimento das Ciências Jurídicas, mantém vários convênios internacionais visando o intercâmbio acadêmico de discentes e docentes.

A Faculdade de Direito da Uerj, bem como a universidade conveniada, não se responsabilizam pelas despesas com viagem e manutenção pessoal. É necessário que o interessado possua meios suficientes para tanto, ou procure fontes alternativas de financiamento. Normalmente não haverá, contudo, quaisquer valores a serem pagos a título de mensalidade / semestralidade / anuidade para a Instituição onde se realizará o intercâmbio acadêmico.

Fotos 89 e 90 - extraídas do mural de Direito da UERJ

O texto contido no cartaz trata de um anúncio de intercâmbio para estudantes em país estrangeiro apontando como critérios para participação do programa o custeio com os gastos da viagem e demais despesas. Estes critérios parecem refletir o discurso de um dos estudantes sobre o tema.

Com as cotas as coisas ficaram mais polarizadas. Eu tava até
conversando com uma moça que é caloura, que é cadeirante. Ás
vezes a pessoa teve até um problema de saúde, é cotista e
precisa trabalhar. Temos que conversar sobre isso. Trazer uma

${ }^{73}$ Lembrando que estas imagens não se encontram, como já mencionado, no acervo das imagensfotográficas usadas nas entrevistas - anexo. O tema foi mencionado em uma das entrevistas feitas com um grupo de estudantes e os discursos levaram a um resgate das fotografias presentes neste acervo maior e, portanto, foram resgatas neste momento do texto. 


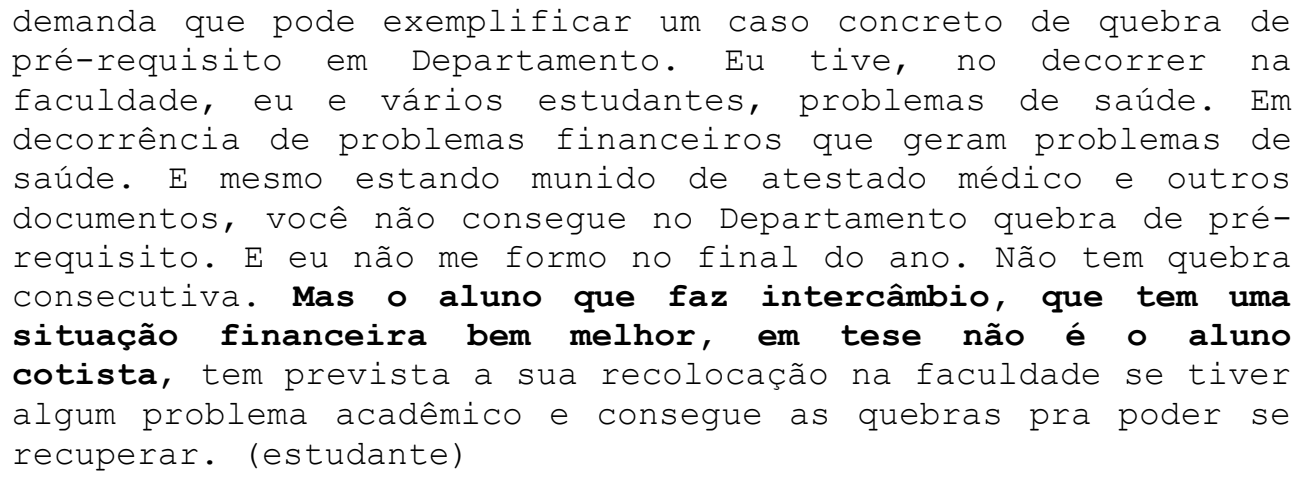

As falas em destaque encaminham uma discussão sobre a próxima categoria a que chamaremos: "Cotistas $x$ cotistas, não-cotistas $x$ não-cotistas, não-cotistas $x$ cotistas: as UERJs e a pluralidade de experiências no convívio com a alteridade", a ser posta em análise a seguir.

\subsubsection{Não-cotistas $x$ Cotistas; Cotistas $x$ cotistas, não-cotistas $x$ não- cotistas: as uerjs e a pluralidade de experiências no convívio com a alteridade}

O processo seletivo do vestibular ocorre, no caso das universidades públicas que aderiram ao sistema de reserva de vagas, da mesma maneira para todos os estudantes. A premissa-base da política é a reserva de vagas de forma a possibilitar aos estudantes condições menos díspares de concorrência, tendo em vista a diferença de realidades e de acesso à qualidade educacional, sobretudo em razão da própria desigualdade na qualidade de educação pública e privada no país.

Esta questão merece uma análise mais atenta devido às controvérsias e tensões geradas pela implementação da política na UERJ, trazendo no bojo da proposta uma série de mitos e boatos que acabam por atravessar as relações sociais dentro do espaço universitário.

$\mathrm{Na}$ pesquisa "Jovens oriundos de pré-vestibulares comunitários: experiências e táticas no convívio com a Alteridade"74, já mencionada, observouse alguns aspectos sobre o convívio entre os estudantes, de classes sociais e culturais distintas, dentro de um espaço voltado para um perfil específico de aluno: o de classe mais favorecida economicamente. Entretanto, se verifica da parte dos grupos, de todas as classes sociais, apreensões sobre a relação entre

\footnotetext{
${ }^{74}$ Esta pesquisa já mencionada anteriormente, se trata de uma investigação feita na PUC-Rio para obtenção de grau de mestre em psicologia, de minha autoria e sob a orientação de Solange Jobim e Souza. Dissertação defendida em março/2007. Ver em referências bibliográficas.
} 
grupos distintos, sendo as experiências permeadas por imaginários e pressupostos que afetavam as relações cotidianas e a convivência entre os grupos. A convivência cotidiana reconfigurou estas relações, corroborando preconceitos, legitimando antigas verdades, mas também, desconstruindo e desmitificando velhos preceitos.

A experiência da PUC-Rio propõe reflexões e dispara questionamentos que servem de subsídios para a presente pesquisa, desta vez em uma Universidade com características peculiares e, portanto, distintas da primeira instituição mas, ao mesmo tempo, com aproximações.

Se tomarmos como ponto de partida o fato de que, no contexto brasileiro, a universidade pública ganha características de instituição privada, sobretudo em alguns cursos mais concorridos, tendo em vista que os estudantes de classe social mais favorecida têm ocupado as vagas das melhores universidades privadas e das públicas, nestes cursos especificamente, então pode se pressupor aproximações nos modos de relacionar-se entre os estudantes nas práticas cotidianas dentro do espaço universitário.

As práticas cotidianas na UERJ precisam, entretanto, serem analisadas considerando suas peculiaridades e idiossincrasias. Antes de tudo, há que se falar em UERJs e não em um bloco monolítico. Esta constatação sobressai nos discursos dos entrevistados e nos variados modos de experiências e de relações coexistentes neste cenário.

Um elemento-chave que faz emergir as diferenças das experiências entre cotistas e não-cotistas na UERJ é a característica de cada área de formação, sobretudo em razão da maior ou menor procura pelos cursos, diferença esta confirmada na relação candidato-vaga de cada uma das áreas. Os efeitos da política de reserva de vagas nas relações entre os estudantes na UERJ assumem distintas configurações, se comparados os perfis de alunos de cada uma dessas áreas e as mudanças advindas do sistema de reserva de vagas na configuração do corpo docente.

Em entrevista com uma professora da instituição, a mesma salienta que a UERJ sempre foi uma instituição com um alunado de origem popular. A professora argumenta que a política de assistência estudantil sempre foi necessária em função da necessidade de estudantes desprovidos de condições financeiras para custear a formação. Em função disso, "táticas" são usadas internamente de modo a dar conta destas questões. É o que explica a professora: 


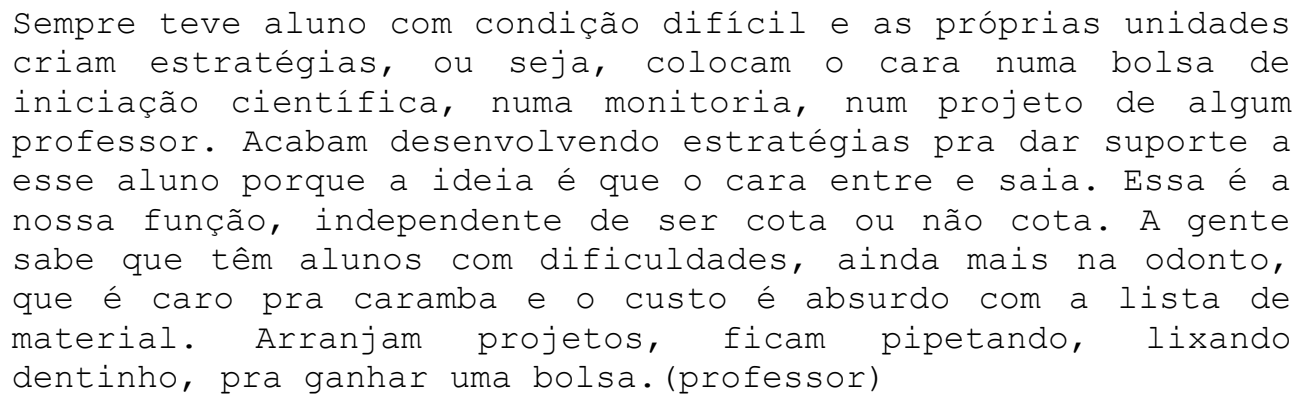

Os relatos precedentes refletem o que Certeau (1994) define pelo conceito de "táticas":

Chamo de tática a ação calculada que é determinada pela ausência de um próprio. Então, nenhuma delimitação de fora Ihe fornece autonomia. A tática não tem por lugar senão o do outro. E por isso deve jogar com o terreno que lhe é imposto tal como o organiza a lei de uma força estranha.(...) Tem que utilizar vigilante, as falhas que as conjunturas particulares vão abrindo na vigilância do poder proprietário. Aí vai caçar. Cria surpresas. Consegue estar onde ninguém espera. É astúcia.(p.101)

Em função da ausência de uma política de assistência estudantil universal, tendo em vista a característica da UERJ como uma universidade criada em prol do estudante-trabalhador, o aluno de classe popular, antes em número reduzido nos cursos mais elitizados da universidade, cria táticas de sobrevivência dentro do próprio espaço, antes mesmo de uma política de ação afirmativa se consolidar de fato.

Nos cursos considerados mais elitizados, que desde longa data prevaleciam alunos oriundos das escolas mais qualificadas e privadas do país, a política de reserva de vagas modificou as configurações do alunado, passando a receber outro perfil de estudante. De acordo com alguns depoimentos de alunos destes cursos, as diferenças sócio-econômicas entre os estudantes cotistas e não-cotistas, nestes casos, são mais expressivas do que nos cursos menos elitizados.

Uma das questões que atravessam as experiências dos estudantes cotistas nestes cursos é a dificuldade do estudante-trabalhador de conciliar a formação e o trabalho. Ao que tudo indica, alguns destes cursos focalizam as estratégias de atuação em função de um outro perfil de estudante. Vejamos a fala a seguir: 


\begin{abstract}
então, de vez em quando, tem disciplina obrigatória que é 4 horas da tarde. De vez em quando tem, e isso dificulta que as pessoas concluam a faculdade, ainda mais quando é requisito para outra disciplina. Você cursa uma faculdade do nível da faculdade de direito, e aí você tem que dividir isso com o trabalho e ainda com as cobranças que nós sabemos que acontecem na sociedade. Isso vai causar problemas relacionados à sua saúde. Se você tem problema de saúde, você não freqüenta a faculdade, se você não freqüenta a faculdade você tem perdas acadêmicas, se você tem perdas acadêmicas você não consegue. olha! Era pra ter uma conclusão feliz! Mas você não consegue quebra de pré-requisito. E aí você se forma em seis anos e meio.
\end{abstract}

Em se tratando dos cursos de menor concorrência no processo seletivo do vestibular, os considerados menos elitizados, a política de reserva de vagas, ao que indicam as entrevistas, manteve a configuração semelhante no que diz respeito às condições socioeconômicas dos estudantes, o que significa dizer que, em uma universidade historicamente voltada para o aluno-trabalhador, nestes cursos, os alunos cotistas e os não-cotistas possuem, de maneira geral, realidades sócio-econômicas semelhantes. Estas considerações foram apontadas por alguns entrevistados, estudantes de alguns destes diferentes cursos.

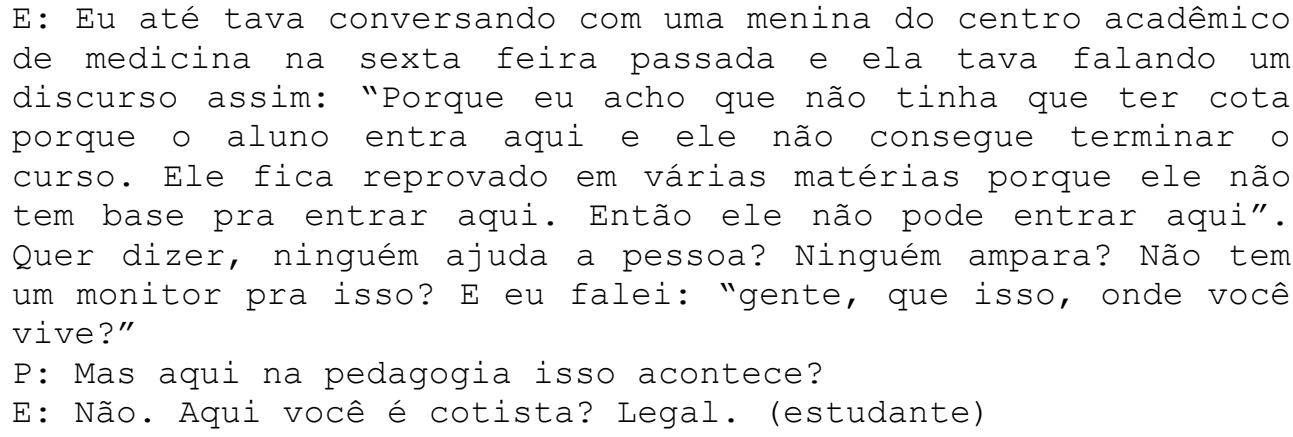

A política de reserva de vagas, entretanto, desencadeou novas questões e impasses, diferentes em função justamente das peculiaridades dos cursos e áreas de formação. É o que se verifica nos relatos de estudantes de um dos cursos mais elitizados, em alusão ao momento de distribuição do kit_cotista ${ }^{75}$.

Alguns relatos revelam certo constrangimento por parte de alguns estudantes cotistas em serem identificados como tais, uma vez que a entrega dos "kit_cotistas" é feita em data estabelecida pelos Centros Acadêmicos e em local visível. Estes relatos sinalizam a devolução e/ou a sobra de uma quantidade de materiais especificamente destinados aos estudantes oriundos

\footnotetext{
${ }^{75}$ Material distribuído aos estudantes cotistas, já mencionado no início deste capítulo.
} 
das cotas, que em caso de não ser entregue aos destinatários, acaba sendo devolvido ao Estado, fonte financiadora de origem. Vejamos o discurso a seguir:

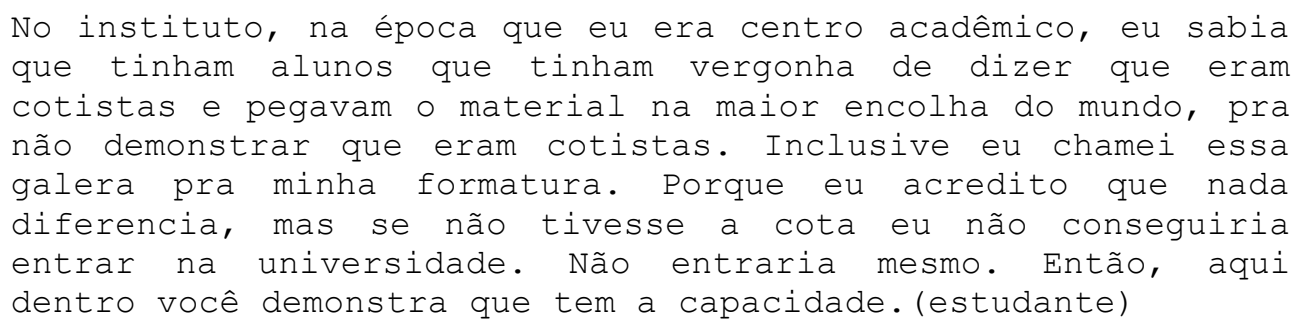

As questões que perpassam as relações entre os estudantes "cotistas e não-cotistas" dos cursos menos elitizados são outras. Partindo do princípio de que a realidade sócio-cultural é bastante semelhante entre os estudantes destes cursos, a distinção que aparece mais premente também tem relação com a distribuição de materiais, mas, desta vez, a reivindicação parte dos estudantes não-cotistas e tem relação com uma política de assistência estudantil que privilegia o aluno oriundo da reserva de vagas, ainda que a maioria dos estudantes do curso tenham necessidades semelhantes. Esta problemática é mencionada ainda pelos atores institucionais que administram a política de assistência estudantil através do programa Proiniciar, no que diz respeito aos cursos e as vagas oferecidas.

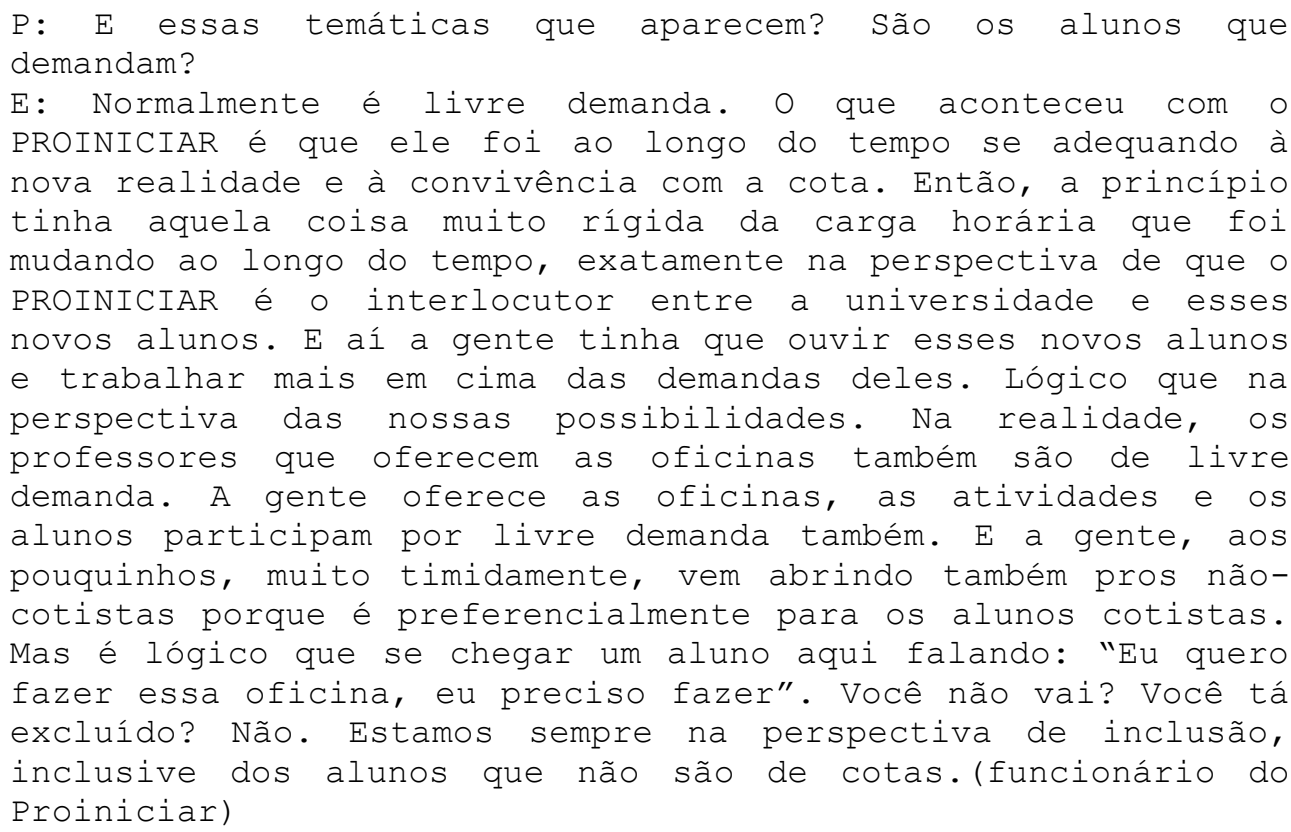

As tensões em torno da política de assistência estudantil também se relevam nas falas dos estudantes, no que refere ao diferente valor cobrado no uso do restaurante universitário para estudantes cotistas e não-cotistas e 
também no que diz respeito ao acesso ao "kit_cotista". Surge, então um impasse em relação a uma política estudantil que deveria ter caráter universal e que, ao mesmo tempo em que é impulsionada pela própria implementação da política de reserva de vagas, acaba diferenciando os estudantes e revelando, principalmente, as dificuldades de vários alunos de uma universidade com características populares e com estrutura e suporte precários no sentido de garantia da permanência dos mesmos na instituição. É o que sinalizam as falas a seguir:

E1: É uma contradição que a universidade pioneira nas cotas no Brasil seja uma das piores em assistência estudantil. O bandejão da UERJ demorou muito tempo pra sair. Quando saiu a verba, O reitor não queria abrir licitação pras obras. A gestão do DCE que tinha ganhado, gestão de 2009, ele recusava, dizia que não tinha agenda pra receber o DCE, e aí - pessoal acabou numa assembleia decidindo ocupar a reitoria. Em 2008 foi a ocupação da reitoria. Conseguiram que abrissem a licitação das obras, que tão quase prontas e a gente tá acompanhando o processo licitatório das refeições. E a licitação colocou o preço máximo de 7 reais, 7,65 da refeição, e o servidor e o professor pagariam o preço inteiro, 7,65, os alunos cotistas teriam subsidio pra ir pra 6 reais e os cotistas pagariam 2,00. Eu acho que o bandejão tinha que ser um tipo de assistência estudantil universal. Não acho que deveria ter diferença de quem é cotista e não cotista. Inclusive isso pode gerar algum constrangimento. Aparentemente eles vão colocar uma espécie de Rio Card.

E2: Identificação eletrônica.

P: Rio Card pra quem é cotista?

E1: Não pra todo mundo.

E2: Eles têm que ter um controle porque vão ser servidas 5000 refeições diárias. Teriam ali algum crédito e a UERJ daria um subsídio pras refeições dos alunos cotistas, os técnicos administrativos pagariam e os professores pagariam o preço inteiro. (estudantes)

Eu acho inclusive que devia ter cota pra essas pessoas que não se encaixam na cota pra negro, pra índio, pra deficiente físico. Devia ser um sistema que privilegiasse a questão social. Tem gente que participa desse embate político aqui dentro e que também precisa, que não tá em nenhuma dessas questões de cotas e que também tem uma condição desfavorável. A galera tem também uma porcentagem de cota, mas os outros além de você comprovar que você é negro, você tem que comprovar uma questão social, socioeconômica. Comprovar que você tem uma renda familiar baixa. Eu acho que contemplaria todo mundo. Mas eu acho que o bandejão tem a ver com a cota e também com essa galera que não é cotista, mas que também necessita do bandejão. (estudante)

A universidade, na verdade, deveria dar assistência para alunos cotistas e carentes, só que acaba incluindo na "carência" os cotistas e não abre uma forma pros alunos carentes que não são cotistas receberem esse auxílio. A gente reivindica que isso seja feito. Se não tem condição você tem 
que reivindicar o seu direito, porque têm muitos cotistas que têm muito mais condição do que quem não é cotista. (funcionário)

As tensões permeiam ainda os processos eleitorais para os centros acadêmicos, presentificadas nas distintas demandas dos estudantes quanto às propostas políticas apresentadas pelas chapas que disputam estes espaços. O depoimento de um dos entrevistados aponta que a proposta de criação de uma creche universitária de uma das chapas - a que perde a eleição para a chapa oponente - é considerada pouco importante por alguns estudantes.

Chama atenção, ainda, o relato a respeito da relação entre os estudantes em jogos estudantis inter-regionais de determinado curso da instituição, quando as torcidas organizadas provenientes de diferentes universidades brasileiras, ressaltam de forma pejorativa o fato da UERJ ter estudantes cotistas. Há que se salientar, entretanto, que os dizeres destas torcidas organizadas nos jogos citados em uma das entrevistas, agregam toda sorte de preconceitos, incluindo os racistas, classistas e contra os cotistas.

\begin{abstract}
Aqui na faculdade a gente tem uma atlética que tem uns jogos jurídicos, nacionais, regionais. E já houve, na verdade sempre há, problemas de racismo nos jogos. O que acontece é que nas torcidas, a da UERJ inclusive, a maior parte das músicas têm algum tipo de preconceito. Têm músicas extremamente machistas e a UERJ sofre muito com as músicas racistas. Por exemplo: a que uma certa universidade canta muito: "Eu não sou racista. Eu simplesmente não gosto de cotista!" Já teve um jogo que tinha uma menina do meu time que era negra, que inclusive não é cotista. (Ela era até outdoor do cursinho dela por aí). E ficavam cantando isso pra ela e ela dizia: "mas eu não sou cotista!" As pessoas até pararam. Mas, em 2009, o pessoal de uma universidade tava escrevendo assim: "cotistas imundos", num quadro negro, apontando pros jogadores negros e acabou que aqui na faculdade de direito, aqui na atlética, incorporou numa medida positiva - porque é estereotipada - essa identidade. Tiveram uns jogos que imitaram macacos pros nossos jogadores e aí surgiu a ideia, o mito de que a UERJ é o Congo. A nossa atlética é o congo. As pessoas têm orgulho disso e resolveram falar: "olha, somos negros sim!" E aí têm as músicas. Uma das que são mais emblemáticas é a que pessoal se junta e fala: "três, dois, um, e aé! há!hu!Hu! nós acaba com vocês!" (propositalmente com erro de português). "Nós somos conguru! E vamu pegar vocês, huhuhuhu!" E têm músicas do tipo: "A UERJ é um Congo, você tem razão, aqui todo mundo têm 'p.' de negão!" ( estudante)
\end{abstract}

Abaixo uma imagem, presente no acervo mais amplo das fotografias, uma referência à República do Congo, mencionada no discurso do estudante: 


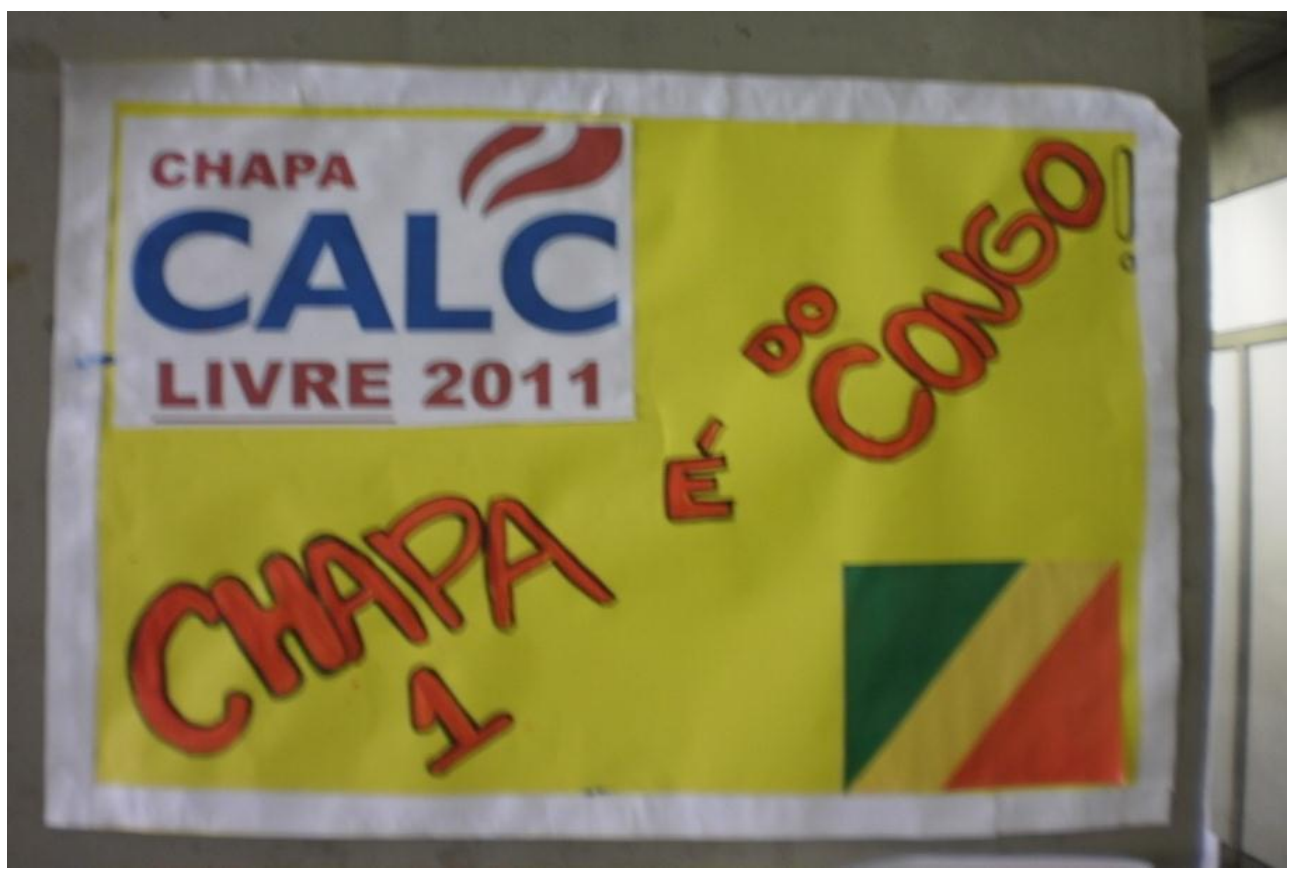

Foto 91 - Campanha eleitoral/CAs

A relação entre visibilidade e invisibilidade merece análise mais detida frente à variedade de recortes de reserva de vagas na UERJ e aos diferentes modos de perceber estas políticas por parte dos entrevistados. Ao que parece, os estudantes ingressantes de reserva de vagas por outros recortes que não o racial e o social vivem certa invisibilidade, em função do número minoritário dentro de um contingente mais amplo de cotistas ingressos pelas demais políticas em função da menor repercussão no cenário sócio-político mais abrangente. 


\subsubsection{Os "jogos políticos" e a "Arena de Forças"}

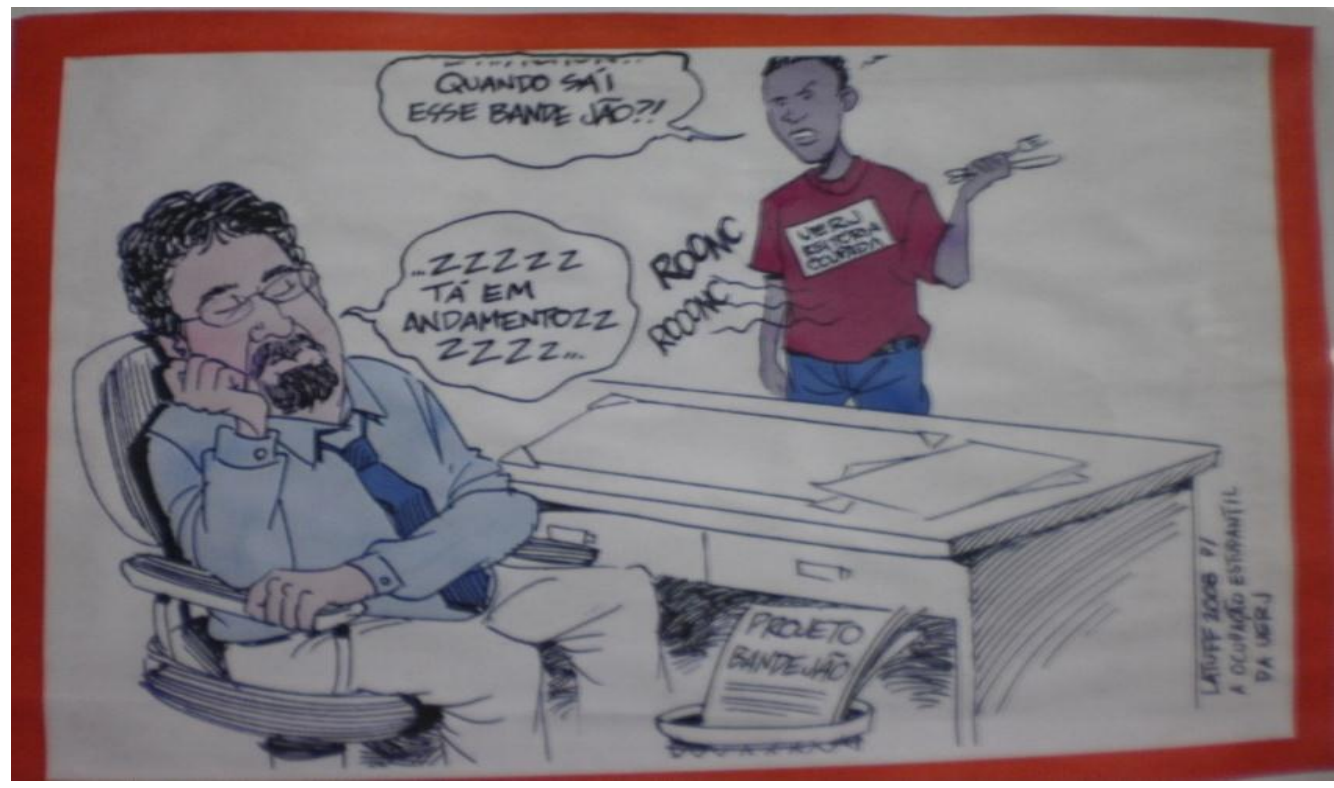

"Bandejão: embates entre estudantes e reitoria" (foto 88/reapresentação)

A imagem do cartunista Latuff já antes apresentada (foto 88), refere-se a um processo eleitoral para eleição de representação do centro acadêmico de determinado curso. A apresentação desta foto aos entrevistados provoca nos estudantes grande mobilização. Os discursos sinalizam alguns aspectos a respeito dos modos como as relações se estabelecem e levantam alguns questionamentos sobre o que a política de reserva de vagas fez fazer no cenário da universidade.

A expectativa de instauração de um restaurante universitário na UERJ vem de longa data. A maior parte dos entrevistados, em especial as antigas gerações, salienta a existência desta reivindicação desde tempos em que não havia na UERJ uma política de ação afirmativa para educação superior, nos moldes da política atual. Ainda assim, os embates e conflitos entre a instituição e os alunos, com destaque para a participação dos movimentos estudantis, "fervilha" hoje no cenário da universidade em frente à eminência de concretização do projeto.

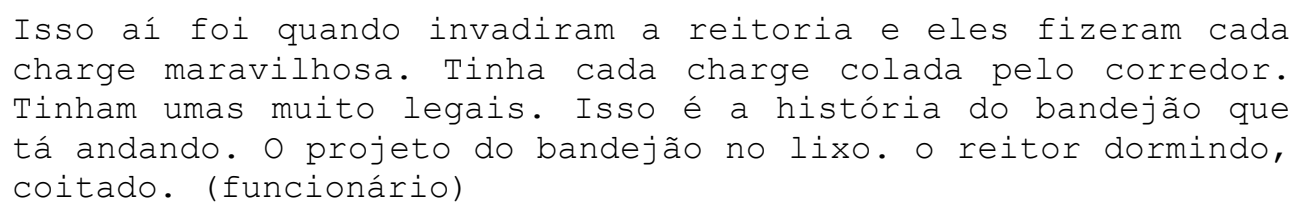




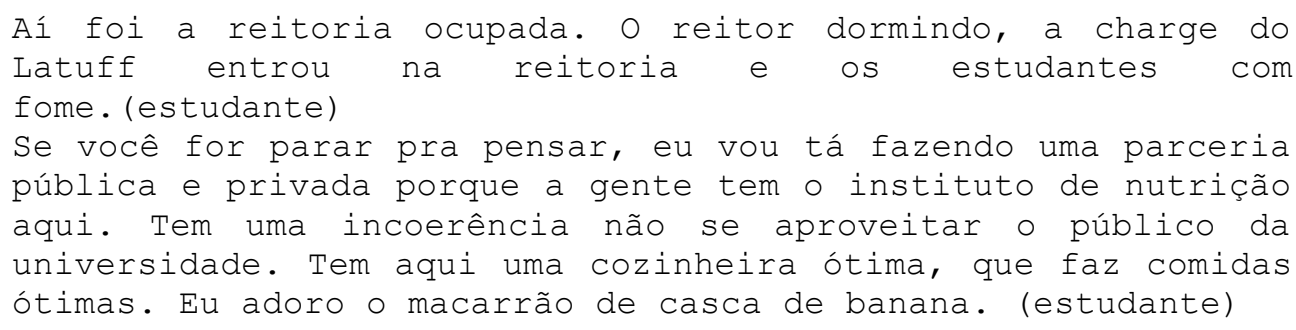

Em meio a brigas e desentendimentos de toda ordem, aliados às reivindicações e manifestações de estudantes-militantes, inclusive culminando com um ato de ocupação da Reitoria da universidade pelos diversos grupos de movimentos estudantis, o projeto parece - é o acreditam vários entrevistados -, próximo de se concretizar. Cabe o seguinte questionamento: "A política de reserva de vagas na UERJ exerceu alguma influência na concretização do projeto do restaurante universitário?".

A questão acima se torna ainda mais pertinente quando uma das fotografias, de antiga data, encontrada na entrada do Centro Acadêmico do Curso de Serviço Social, retrata a já existência da luta pela assistência estudantil e deflagra um debate sobre a distinção entre benefício e direito. O que a imagem sinaliza é que a luta bastante atual pela assistência estudantil na UERJ já fazia parte das pautas de reivindicações de antigos movimentos políticos organizados na mesma universidade. Segue a fotografia em questão:

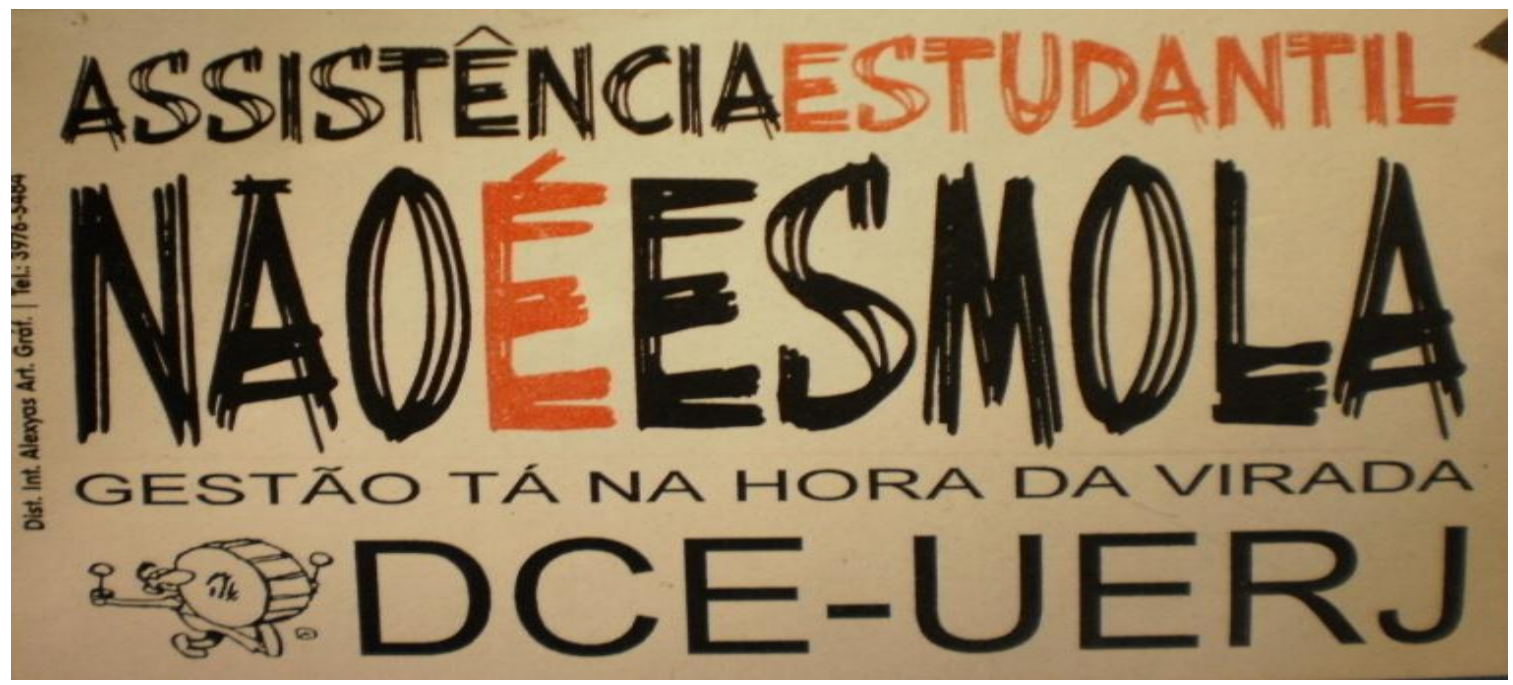

Foto 92 "Adesivos CASS_pela assistência estudantil como direito"

Alguns entrevistados acreditam que a implementação do bandejão, neste momento, não teria relação direta com a política de reserva de vagas. Entretanto, seria usada, em algumas situações, como mote de campanha política de grupos variados. Outros asseveram que a implementação de uma 
política de reserva de vagas na UERJ acaba funcionando como "peso argumentativo", expressão usada por um dos estudantes em entrevista nesta pesquisa. O que significaria dizer que, uma política desta natureza seria um forte motivo para que, nesta instituição, mais do que em qualquer outra, existisse uma política de assistência estudantil séria e consistente. A discussão divide opiniões entre os estudantes. Abaixo-citadas, duas falas com diferentes pontos de vistas:

\begin{abstract}
E1: Eu acho que não. O sistema de cotas já foi adotado há um bom tempo. Acho que foi mais pela pressão dos estudantes e também quando foi liberada a verba, que foi o Freixo que liberou. Acho que teve a ver com isso também e, principalmente, sempre teve a pressão dos estudantes. Mas, com ocupação da reitoria de tanto tempo, que isso chegou. E as obras foram muito devagar, inclusive com irregularidade no contrato.

E2: Eu já tenho uma visão diferente. Eu acho que influenciou sim porque você tem um grupo específico de pessoas em que a origem do benefício das ações afirmativas já pressupõe esse tipo de assistência. Se a UERJ é pioneira no Rio de Janeiro e é referência, inclusive para O STF no Brasil, como que a UERJ não trata o aluno, principalmente esse aluno cotista? A distribuição, a entrega dos livros, o material didático e agora o bandejão, ela tem a influência sim. Ela não tem um peso prático, mas ela tem um peso argumentativo. Inclusive os grupos de alunos aqui da UERJ utilizam, no seu material de divulgação, as cotas como um dos principais argumentos a favor do bandejão. É o que eu disse e reitero: são alguns anos acompanhando vários grupos que passaram pela UERJ desde 2005.2. Na questão argumentativa, que tem peso, tem sim: em época de eleição, motivo pra invadir reitoria, motivo pra ocupar reitoria, motivo pra você dar entrevista em algum lugar, pra reivindicar. (estudantes)
\end{abstract}

\begin{abstract}
Numa universidade onde 50\% são cotistas, eu acho muito importante o bandejão. Numa universidade que têm muitos alunos carentes que não têm condições financeiras, ter um bandejão pra poder se alimentar, principalmente agora que saiu uma minuta que o bandejão sairia por 6 reais, o que é um absurdo. 6,00 eu como no DALB. Sendo que 4 e pouco é no bandejão da PUC. Absurdo! O bandejão tá pra sair. O reitor assinou em 2008. Vai ser em cima no Itaú, um lugar super pequeno, e até agora ele não saiu do papel. Nós tivemos até um ato lá embaixo pedindo que o bandejão seja gratuito, principalmente para os estudantes. E se não for gratuito que seja mais barato, porque 6,00 é impossível. Numa universidade do tamanho da UERJ onde têm muitos alunos que não têm condições financeiras e que, às vezes tem que ficar o dia todo aqui, principalmente algumas pessoas que militam dentro da UERJ, é um absurdo não ter um bandejão. (estudante)
\end{abstract}

Através do registro fotográfico foi possível acompanhar as pautas de campanha de alguns dos processos eleitorais para as gestões dos CAs. O que fica proeminente é que a instalação do bandejão na UERJ aparece na maioria 
das campanhas. Curiosa é, entretanto, a maneira com que o assunto é tratado nos cartazes dos estudantes: ora sob a forma de denúncia, atribuindo a responsabilidade pela não concretização do projeto à reitoria, ora tomando para si o mérito da concretização do projeto, em função da pressão exercida sobre os poderes instituídos.

Ainda analisando a imagem, ela expõe, de modo irreverente, uma cena em que o Reitor estaria, supostamente, "engavetando" o projeto do bandejão, enquanto os estudantes questionam a morosidade de sua concretização efetiva $^{76}$.

De outro modo, exposta em jornal da UERJ em um dos murais da universidade, uma entrevista com o Reitor ressalta supostas conquistas adquiridas durante o período de seu Mandato. Esta imagem, que agrega a fotografia do próprio Reitor com seu depoimento, provoca nos entrevistados reações, tendo sido esta uma das fotografias mais comentadas e geradoras de polêmicas.

\footnotetext{
${ }^{76}$ Vale salientar que a charge acima apresentada é assinada pelo Catunista Latuff, já antes mencionado.
} 
Durante sua gestão várias projetos estão sendo tirados do papel, como o restaurante universitário e o centro esportivo. Que outras realizações o senhor destacaria?

Conseguimos implementar o plano de carreira docente; pagamos dividas; concedemos reajuste salarial de $22 \%$ para os técnicos-administrativos depois de dez anos; aumentamos a bolsa dos estudantes em mais de $60 \%$; -xpandimos a bolsa dos cotistas, que era de um ano, para todo o curso; estamos terminando o restaurante universitário e o centro poliesportivo; recompusemos quase toda a infraestrutura da Universidade, incluindo o telhado e o subsolo do Pavilhão Haroldo Lisboa da Cunha (Haroldinho).

(Continua na próxima página)

Foto 92 - "Jornal da UERJ_entrevista com o reitor_2"

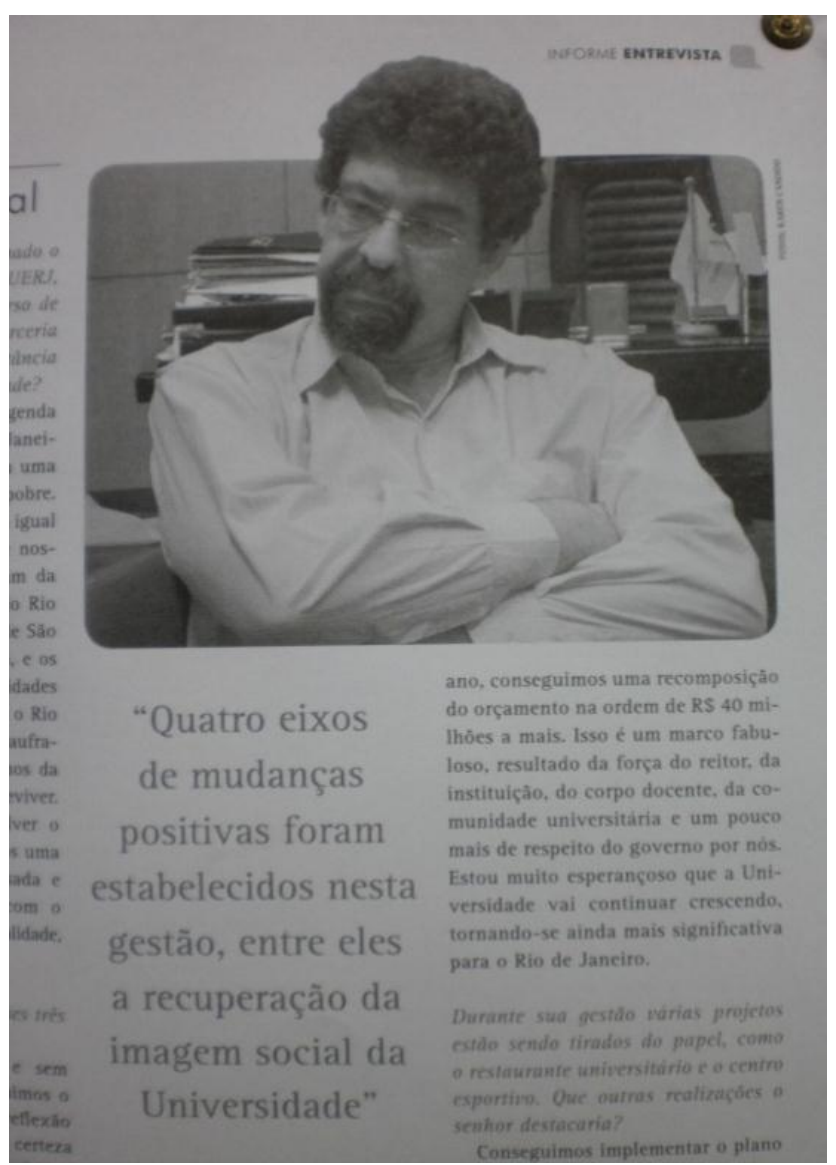

Foto 93 - "Jornal da UERJ_entrevista com o reitor_2" 
No jornal acima, o Reitor, em entrevista concedida ao jornal da universidade de título "Informe UERJ", menciona entre as supostas realizações de sua gestão: "o aumento da bolsa dos estudantes em mais de 60\%"; "a expansão da bolsa dos cotistas, passando de um ano para todo o curso" e o "término no restaurante universitário".

Os embates e controvérsias sinalizam, portanto, a arena de conflitos entre os grupos nas suas diferentes posições, o que explica a grande repercussão que desencadeia a figura do Reitor e seu discurso - representante do poder instituído -, especificamente referentes à política de reserva de vagas. Vejamos as diferentes reações que a entrevista apresentada na fotografia provoca nos grupos entrevistados:

\footnotetext{
E1: O reitor. Isso tem a ver com essa política que a gente falou de recuperar a imagem da universidade.

E2: Foi na gestão dele que se conseguiu, na verdade, a bolsa permanência até o final do curso. Na realidade isso já era uma política que vinha sendo feita. Os movimentos já existiam. O que eu acho característico da gestão dele é a questão de mudar a visão da UERJ. A UERJ tava muito "mal na fita" nos últimos quatro anos, por causa daquelas greves. Ficamos parados quase um ano. O reflexo, o retrato, é o bendito vestibular. Então, nós tivemos anos de pouca procura, de evasão absurda. Ao longo desse tempo a UERJ conseguiu recuperar, aí não só o Ricardo, mas todo a administração dele, conseguiu recuperar essa imagem de que sempre foi uma universidade urbana, que sempre trabalhou com o trabalhador, por isso tem curso noturno, que as cotas existem mas as cotas não mudaram completamente o perfil da UERJ porque a UERJ sempre teve o aluno trabalhador. A UERJ tava margeando a linha de trem, tinha uma característica e ao longo do tempo ela ficou omissa como uma má universidade, por questões estruturais. Ao longo dos anos a UERJ, com suas limitações e com suas boas coisas, conseguiu recuperar sua imagem com a cidade do Rio de Janeiro. Eu acho que ele teve um papel importante como líder nessa transformação. (funcionários)
}

De outra maneira, os movimentos estudantis reivindicam pra si o mérito de efetivação do projeto de consolidação do restaurante universitário, alegando que não se trata de um feito da atual gestão da Reitoria, mas do resultado das lutas e manifestações feitas pelos estudantes. Consideram, muitos deles, que a iniciativa que coloca em prática o projeto por parte da gestão da reitoria, no momento atual e não em outro, decorreria, sobretudo, do momento eleitoral pertinente, sob a alegação de ter sido usado como mote de campanha para uma possível reeleição. Vejamos o que dizem os estudantes nas falas seguintes:

$\mathrm{Na}$ verdade ele não expandiu nada. A lei obrigou que ele expandisse porque a lei é muito clara e objetiva nesse 
aspecto, enquanto o aluno cursar e comprovar sua situação (vou falar essa palavra que eu odeio, que é "carência") de carência. É por isso que é permitida sua análise socioeconômica pra estabelecer e evitar fraude. Então, o reitor é um fanfarrão! Ele não só utiliza, como utilizou o acúmulo de bolsas como uma questão política, que ficou na mesa dele travada há muito tempo, ele não implementou e implementou agora. Aliás, é muito peculiar do reitor, o que me deixa muito preocupado e muito decepcionado. Temos muitas pessoas assim, que utilizam essas questões que vão impactar a vida de seres humanos como uma "reles" política e como instrumento de politicagem. Então, o "senhor reitor" é um "fanfarrão"! (estudante)

E1: Pára de mentir!

E2: Ah gente, eu gosto dele! Não fala mal dele não!

E1: Que horror!

E2: Eu gosto!

E1: Não tem como!

E2: Mas eu não tenho nenhum motivo específico.

E1: Até agora ele passou totalmente por cima do estatuto da UERJ quando ele bota a reeleição.

E2: Isso aí eu concordo com você.

E1: Não é a primeira vez que se passa por cima do Estatuto da UERJ pra conseguir alguma coisa em beneficio próprio.

E2: É, mas, eu vou entrar em defesa dele só em um ponto. O que eu observo é um trabalho imenso que eles tentam fazer de angariar o dinheiro, aliás, não é nem angariar é trazer o dinheiro pra cá. O estado não tá pagando dinheiro de muita coisa, de muita gente que tem pra receber há dez, vinte anos e a UERJ teria pra receber 1\% do dinheiro do estado e as verbas não são liberadas. (estudantes)

É O Reitor. Eu não tenho palavras porque esse cara não merece palavras. Ele deu uma entrevista que chamou os cotistas de "bobos". Aqui na universidade os cotistas têm o rendimento parecido com os demais. Que o cara cotista que entra com uma deficiência em português e não sei aonde, não consegue. O cara não tem nem porque se explicar. A comunidade da UERJ que elegeu. Ele tinha que explicar o porque da contradição. Terminando o restaurante universitário? Pra mim já tá terminado. Ele tá enrolando com os acabamentos pra inaugurar isso durante o processo eleitoral. Se inaugura no início do ano, no final do ano não tem o que ele dizer. Ele não sente alegria de tá inaugurando com um preço teoricamente popular. Isso colabora porque a galera que entrar vai falar: "Vou votar nesse reitor porque ele fez o restaurante universitário!". (estudante)

E1: O Reitor. Eu acho que é um absurdo ele ficar falando essas coisas. Se ele chegar aqui no nono andar vai ver uma sala caindo aos pedaços e você chega na reitoria é completamente diferente.

E2: Não tenho nem o que falar.

E1: Foi pressão dos próprios estudantes na ocupação da reitoria, a construção do bandejão, o acúmulo de bolsas. O bandejão foi da própria ocupação da reitoria e ele só assinou - papel porque nós saímos da reitoria. (estudantes) 
Alguns depoimentos sinalizam divergências entre os projetos políticos de gestão intracursos e entre os grupos oponentes que disputam os CAs, com pautas reivindicatórias com tendências mais populares e outras com campanhas mais voltadas para questões burocráticas, focadas, sobretudo, nas prioridades mercadológicas em função da inserção do estudante no mercado de trabalho.

A proposta de instalação de uma creche universitária, segundo um dos entrevistados, foi pauta de campanha de uma das chapas concorrentes ao CA de certo curso e não teve completa adesão por parte dos estudantes. Estas tendências nos modos de organização e direção das gestões dos movimentos estudantis trazem ou não pautas relativas à política de assistência estudantil. Os "estudantes-cotistas" são alvo de "bandeiras" eleitorais, público-alvo de algumas campanhas e, encontram-se ausentes em outras.

\footnotetext{
E1: A instalação de uma creche universitária. Essa é a situação de muitos alunos aqui. Essa realidade, muitos acham que não existe. Pra eles, essa pessoa, se ela tem uma filha, deu mole. E se deu mole, deixa com a mãe pra criar ou deixa pro pai pra tomar conta, pede ao vizinho. É uma galera com 17 e 18 anos que entra na universidade sem responsabilidade nenhuma. Isso aí não interessa pra eles. Eu escutei no processo eleitoral e deixou a gente muito triste: que "isso não tem nada a ver com a gente". Inclusive foi uma menina! Aí eu virei e falei assim: "você não sabe o dia de amanha. Você namora? Você pode ficar grávida! Você teria essa facilidade que você tá dizendo?" Ela ficou calada e não quis mais responder. Simplesmente virou as costas. Mesmo ela sabendo sobre tudo o que pode acontecer, não diz respeito a ela. P: Tem alguma coisa a ver com a questão da classe social? A1: Tem! Porque essa galera de 17 e 18 anos que entra é de classe média alta. Foi isso que eu quis colocar desde o início. Não têm interesse em divulgar material de cotistas. Têm de tudo! (estudantes)
}

As afiliações entre os estudantes nas diferentes posições assumidas pelos movimentos estudantis das chapas concorrentes para os CAs mostram de outra maneira as aproximações e distanciamentos entre os estudantes. Os depoimentos abaixo sinalizam as identificações entre grupos militantes de mesma orientação política intercursos e a não identificação de estudantes dentro de um mesmo curso. O que parece é uma cisão dentro dos cursos e uma identificação entre estudantes cotistas de diferentes cursos em função dos interesses, prioridades, propostas de atuação políticas, entre outros. 
nono andar. Era o CA de educação física, de ciência sociais, de história, de filosofia, se não me engano tinha mais um outro. A gente pegou 2, 5 CAs e se fechava. De forma que um CA sempre chamava o outro, desde a parte esportiva até as questões políticas. (estudante)

O nosso material de cotista, hoje, chegou o de 2010. Até hoje eu venho cobrando o centro acadêmico se foi entregue ou não esse material pros cotistas. Eles não foram pegar o material até hoje pra fazer essa entrega. Não estão ligando porque eles não têm direito, não são interessados, nem em pegar material, porque eles não têm nada a receber nem em distribuir pra quem tem direito. Então, o material tá lá, totalmente jogado no canto da direção. (estudante)

A gente tentou não perder essa característica do desporto. Tem as olimpíadas aí, mas nossa área é diretamente ligada com isso e ninguém da área de educação física participa de nada pra construir isso. Não quer saber de nada politicamente. A galera não tem interesse. É por isso que tem equipe de tudo na educação física: equipe de judô, tem até equipe de peteca. Todas as equipes que têm lá. Só isso... e festa. (estudante)

Além de ser uma galera da direita. Eu não chamo essa galera de oposição. Quando você diz oposição, tem um lado bem definido e um outro lado, contrário ao que você está. Essa galera não tem. Aí é que está. A gente não sabe onde eles estão, pra onde eles vão. Eles não têm perspectiva neste sentido. Eles acreditam que eles são apolíticos, que eles são apartidários. Acho que, se você tá num lugar dialogando por uma coisa, você tá fazendo política. Falar que ele é apolítico? Pra mim não existe sentido nenhum. (estudante)

O último discurso destacado retoma a discussão sobre os modos de fazer política hoje, sobretudo sobre o próprio conceito de "política". As reflexões de Arendt (1998) dialogam com as considerações deste estudante. A autora considera que a política não pertence a algo de essencialmente humano, como se houvesse algo político que pertencente à sua essência. "A política surge no entre-os-homens; portanto, totalmente fora dos homens. Por conseguinte, não existe nenhuma substância política original. A política surge no intra-espaço e se estabelece como relação". (1998, p.23)

Arendt (1998) associa política à ação e à liberdade. A autora entende por "político o âmbito mundial no qual os homens se apresentam, sobretudo com atuantes, conferindo aos assuntos mundanos uma durabilidade que em geral não lhes é característica". (p.26)

Arendt (1998) referia-se aos preconceitos que são lançados sobre a política, quando esta estaria associada estritamente ao fazer político profissional, "a concepção de a política ser, em seu âmago, uma teia feita de velhacaria de 
interesses mesquinhos e de ideologia mais mesquinha ainda, ao passo que a política exterior oscila entre a propaganda vazia e a pura violência (...)". (p.27)

O sentido da política vinculado ao "agir", em Arendt (1998) diz respeito à possibilidade do homem de "desencadear processos", o "poder impor um novo começo, começar algo de novo, tomar iniciativa" (p.43)

De acordo com a autora, o próprio julgamento, o preconceito com a política profissional constitui-se um ato político, no sentido de que política é formação de opinião, julgamento, produz efeitos. (p.30)

As questões abordadas nos capítulos subsequentes se refletem nesta última etapa da pesquisa e sinalizam que: a política de reserva de vagas seria mais que, estritamente uma política de Estado que se propõe a transformar os rumos da universidade, mas, põe á mostra, sobretudo, outras temáticas como as relações raciais no Brasil, a educação de modo mais abrangente, as disputas de poder em torno dos quais se estruturam os modos de funcionamento da universidade, as condições de desigualdade social e estrutural que marcam o cenário sócio-político brasileiro, dentre outras.

\section{Considerações "finais"}

As polêmicas e controvérsias em torno da implementação do sistema de reserva de vagas em universidades públicas brasileiras, que vêm confrontando estudantes, professores e pesquisadores em grandes arenas de debates - além da sociedade civil mais ampla -, estão longe de cessar.

Os impasses que surgem de uma proposta em processo de consolidação convocam cotidianamente estratégias de enfrentamento por parte das instituições e dos sujeitos que dela participam (no caso destes, estratégias e táticas).

Deste modo, as reflexões e discussões não poderiam encerrar-se em um texto. Mas o trabalho precisa de um fechamento, embora seja importante considerar que o início não se dá no ponto de partida de sua escritura, tampouco a última palavra escrita representa seu final. Bakhtin (2003), que esteve presente antes e por todo o percurso deste trajeto, nos faz lembrar que "não existe a primeira nem a última palavra, e não há limites para o contexto dialógico (este se estende ao passado em limites sem limites e ao futuro sem limites)" (p.179) Um "alinhavo" das discussões que mais sobressaltaram ao pesquisador, nas suas impressões e análises, seria um caminho possível para esta etapa final. 
É preciso por em relevo alguns aspectos que a pesquisa e a feitura do trabalho escrito fizeram surgir. Estes aspectos serão situados a partir de dois eixos centrais de análise: 1. As concepções de sujeito e de subjetividade que alicerçam um modo de pensar/fazer psicologia, na sua interface com a educação, e as possíveis contribuições para o enfrentamento do tema das ações afirmativas no contexto atual; 2 . Modos de fazer pesquisa em ciências humanas que se coadunem com os pressupostos teórico-filosóficos aqui abordados, partindo, sobretudo, de uma dimensão interdisciplinar do conhecimento e de uma implicação ético-politica no ato de pesquisar.

Analisar as práticas cotidianas implica necessariamente em considerar o sujeito em uma dialética com a sociedade. É neste sentido que as experiências dos sujeitos, ainda que singulares e idiossincráticas, precisam ser consideradas na interlocução com as especificidades dos contextos nos quais suas práticas cotidianas acontecem.

Neste sentido, conhecer o campo de investigação não é possível antes do início do processo. Analisar as redes de relações dentro de determinado espaço exige, sobretudo, considerar a pluralidade de realidades, de contingências e de demandas dentro de um contexto que agrega uma diversidade de modos de ser/existir e de modos de relação.

No caso em tela - o da Universidade do Estado do Rio de Janeiro - há que se falar em UERJs e não em uma só. Tomar o campus da UERJ como um bloco único, homogêneo, de forma a construir verdades na tentativa de replicá-las e transpô-las para outros contextos distintos, seria o mesmo que negligenciar a diversidade de formas de experiências que coexistem em diferentes contextos. As observações e reflexões suscitadas nesta experiência podem, no entanto, servir de subsídios para reflexões outras, que surgem como reflexos de uma realidade e conjuntura mais amplas e que se presentificam, de modos singulares, nos espaços das universidades.

Nesta mesma linha de análise, a dimensão dialógica entre a Universidade e a Cidade, tendo em vista o arrefecimento das linhas divisórias entre ambos, faz extrapolar as análises do microcosmo da universidade para seus espaços extramuros.

Em se tratando do tema do trabalho - a política de reserva de vagas na UERJ e os modos de fazer cotidianos -, a pesquisa vem mostrar, justamente, a divisão tênue entre a cidade e a universidade, uma vez que a política afeta as práticas cotidianas e as relações sociais que operam na própria cidade e abre 
brechas para que problemáticas nela vivenciadas circulem e sejam postas em discussão no espaço intramuros da universidade. A rede de preconceitos e de desigualdades de uma cidade atravessada pela lógica do capital é um dos aspectos proeminentes, seguido das tensões próprias da convivência entre os sujeitos em condições desiguais cultural e economicamente.

O sujeito é político. Não em decorrência de uma essência política, mas, como entende Arendt (1998), por sua possibilidade de renovação, de liberdade, de julgamento, de crítica. Acompanhar os fluxos cotidianos na universidade trouxe reflexões sobre os modos de fazer política (entendendo por política "ação", "tomar posição") e sobre as maneiras como este "fazer político" se configuram hoje, situando especialmente o lugar da juventude neste cenário.

O que levam os jovens ao engajamento político e a afiliações a grupos militantes com propostas políticas específicas? Quais seriam as motivações e pautadas em que interesses? Identificações a causas particulares? Interesses coletivos? A política de reserva de vagas traz para o contexto da universidade as nuances destas afiliações e a hibridização dos grupos, tendo em vista que as questões perpassam os sujeitos de modos particulares e coletivos simultaneamente.

Analisando os grupos de estudantes militantes e suas participações no manejo da política de reserva de vagas na UERJ, notam-se aproximações de alguns integrantes destes grupos em interesses comuns e pontos de vistas semelhantes e, em outros momentos, divergências quanto aos posicionamentos, encaminhando para um entendimento de construção de subjetividade processual, contingencial e atravessada por uma rede de agenciamentos, pondo em confluência as dimensões individual e coletiva como constitutivas de identidades e de subjetividades.

As experiências dos sujeitos no convívio com a alteridade desmitificam pré-concepções, corroboram antigas crenças e possibilitam aproximações. As negociações são possíveis em algumas instâncias e, em outras, as tensões e as des-identificações ficam sobressalentes, ressaltando, sobretudo, as diferenças sociais e os distintos posicionamentos frente à realidade.

Projetos distintos de sociedade colocam-se em evidência nos jogos de forças e nas relações sociais dentro do espaço da universidade, na medida em que os sujeitos são convocados a se posicionar frente a uma proposta política ou outra, quer se vinculando a algum movimento social específico, quer a partir de alguma vinculação partidária ou, seja ainda, no ato de escolher seus 
representantes, em caso de não vinculação a nenhum movimento social organizado ou qualquer outra atividade política profissional.

O que a política de reserva de vagas fez existir no cotidiano da UERJ? A questão-chave da pesquisa encaminha algumas reflexões. O debate que se apresenta inicialmente dicotomizado, dividindo em polos antagônicos os grupos favoráveis e os contrários à política de reserva de vagas foi superado, ao menos no espaço da universidade, se considerarmos o equívoco de simplificar uma política que abarca tantas nuances, critérios, propostas distintas, universidades e modos de implementação variados, dentre outros aspectos. O que permanece é uma desinformação do que consiste a política de reserva de vagas ou o excesso de informações distorcidas que levava/leva a maior parte das pessoas a posicionarem-se inadvertida e equivocadamente.

Há, entretanto, o silêncio dos que não aprovam, mas precisam conviver com a política, o que provoca efeitos nos "bastidores" das relações intra-muros da UERJ.

A constatação de que algumas vozes dissonantes em relação à política de reserva de vagas silenciaram em função da aprovação da proposta, não significa necessariamente que estas vozes em silêncio tenham sido suprimidas, impedidas de posicionarem-se sob o julgo de retaliações. O que fica latente é a falta de consenso - o que não é um problema, pelo contrário, é o caminho frente à complexidade da proposta e em função dos problemas sociais e políticos que a atravessam.

Fica mais uma vez latente a importância do debate. A falta de discussões sobre o tema envolvendo a sociedade civil mais ampla é que se configura um problema, além da ausência de algumas áreas do conhecimento no enfrentamento destas questões. Não há, portanto, uma divisão entre favoráveis e contrários, mas entre vários outros polos que, ora se encontram e, por vezes, se afastam. A hierarquia entre as áreas de conhecimento são algumas das molas-propulsoras destas divisões.

Um dos estudantes entrevistados sintetizou um dos efeitos significativos da proposta para a universidade e para o cenário sócio-político mais amplo: A "política de cotas" funcionou como "peso argumentativo" para a implementação de uma proposta de assistência estudantil já antes almejada e necessária. Ora, uma das universidades pioneiras na implantação da política de reserva de vagas no Brasil não poderia não ter uma proposta de assistência estudantil em condições razoáveis de funcionamento. 
A ausência de um restaurante universitário - o bandejão - sempre esteve na pauta dos movimentos militantes da UERJ. O "peso argumentativo" de uma política de reserva de vagas tornaram visíveis as dificuldades já antes enfrentadas pelo estudante de camada popular na instituição. Contudo, o perfil deste estudante, que agora é chamado de "cotista", sempre existiu de modo expressivo e especialmente nos cursos em que a relação candidato-vaga era mais expressiva, em número bastante reduzido. Suas trajetórias contavam com táticas individuais de sobrevivência na universidade, uma vez que não havia uma política de permanência como a que existe, hoje, na sua configuração atual.

O fato da existência de uma política de permanência hoje na instituição, contudo, não soluciona todos os impasses. As estratégias e propostas visam atender prioritariamente o estudante ingressante via sistema de cotas, excluindo outros estudantes com condições semelhantes financeiramente e que continuam contando com suas próprias alternativas e perspicácias criativas para manteremse na universidade.

As brechas do sistema educacional precário e as táticas de enfrentamento dos estudantes e profissionais vindo à tona a partir da política de reserva de vagas também foram notórias. É importante frisar que os entraves não decorrem de suposta falibilidade do sistema de política de cotas, mas da falibilidade da estrutura educacional, especialmente das condições macroestruturais da universidade pública brasileira, que a política de cotas faz revelar.

As tensões que atravessam as relações entre os sujeitos que participam e são contemplados pela política cotidianamente não deslegitima o sistema como proposta, mas coloca em cheque as contradições sócio-políticas e a precariedade do sistema educacional brasileiro. Revelam-se, sobretudo, as táticas de enfrentamento e a necessidade de uma política de assistência estudantil que contemple a desigualdade de condições sociais e econômicas que vêm à tona de modo mais veemente com a política de reserva de vagas e com a repercussão que o projeto ganha no cenário social mais amplo.

Em se tratando da repercussão social, o debate sobre o racismo no Brasil toma a cena. A pesquisa aponta a importância de uma política que traz à tona discussões que ficam escamoteadas e submersas sob a premissa da existência de uma democracia racial brasileira e sob a alegação da suposta impossibilidade de uma identificação racial no país em razão do processo de miscigenação. Ressalta-se, no entanto, que esta identificação racial é feita cotidianamente nos trajetos e percursos dos sujeitos pela cidade, construindo subjetividades 
marcadas pela exclusão e pela invisibilidade que estas relações na cidade provocam.

Se um ou outro critério é mais ou menos justo para ser adotado em uma política de reserva de vagas nas universidades? Seria leviana uma afirmação taxativa e contundente, uma vez que é preciso analisá-los junto às experiências de cada proposta, em cada contexto de implementação. Contudo, é preciso não perder de vista os modos como os sujeitos constituem suas identidades e as maneiras de situarem-se e de sentirem-se pertencentes no mundo, a partir das relações que estabelecem na cidade cotidianamente.

Os processos de aculturação e as relações marcadas pelos valores e estrutura impostos pelo sistema capitalista de produção, participam da constituição subjetiva dos sujeitos e isso deve ser levado em conta frente à afirmação de que identificação racial depende de uma normativa universal que coloca o outro como o julgador da sua condição de sujeito. Em outros termos, autodeclarar-se implica em dar espaço para que o próprio sujeito possa, ele mesmo, afirmar sua identidade, a partir do modo como ele se percebe. E esta auto-percepção não está desvinculada da relação com a sociedade em que o mesmo encontra-se inserido.

Analisando os desdobramentos da pesquisa sob outra perspectiva, as considerações precedentes suscitam reflexões sobre a prática da pesquisa em ciências humanas e seus efeitos, uma vez que a delimitação de uma proposta metodológica específica, mais ainda, sobre a posição assumida pelo pesquisador nas suas ações e olhares sobre o objeto de investigação, relacionam-se diretamente aos "resultados"/frutos deste processo.

Jobim e Souza (2000) analisa uma epistemologia das ciências humanas a partir de Bakhtin e entende que:

O conhecimento que se revela a partir do encontro do pesquisador com o outro não pode, ele mesmo, ser forçado a um enquadramento que o limite, mas deve se manter livre e, ao se manter livre, não oferece garantias em todas as mudanças. (...) cabe às ciências humanas encontrarem estratégias metodológicas que dêem conta desta dimensão de liberdade que deve ser a principal garantia para nos mantermos como pesquisadores, fiéis à especificidade das ciências que estudam o homem. (p.02)

A proposta de uma investigação que pretende analisar as práticas cotidianas e os modos de participação de sujeitos em um determinado contexto, sob a égide da psicologia social ${ }^{77}$ encaminha reflexões a respeito do próprio ato

\footnotetext{
${ }^{77}$ Especificamente a partir dos preceitos da chamada psicologia social sócio-crítica.
} 
de pesquisar e de suas implicações ético-políticas no campo das ciências humanas.

A proposta metodológica não tem menos importância do que os desdobramentos que a pesquisa suscita. Nesta medida, não é possível delimitar os recursos e métodos usados na prática da pesquisa antes mesmo de conhecer as características e especificidades do contexto de investigação.

O que se pretendeu por em relevo no capítulo que apresenta a proposta metodológica (embora a construção da metodologica atravesse o trabalho como um todo) foi "o descortinar" de um método de pesquisa que se relaciona, sobretudo, com as peculiaridades do contexto de investigação. É desta maneira que o registro fotográfico surge como possível ferramenta metodológica, que se justifica em função das "paredes que falam na UERJ", cuja apropriação em um contexto diferente poderia - provável - se transformar em um recurso replicável desconexo e sem proveito.

A relação do pesquisador com o campo de pesquisa também se configura importante elemento no processo. As entrevistas, o acesso aos sujeitos da pesquisa, as andanças do pesquisador pelos corredores e as demarcações geográfico-espaciais, aconteceram de certo modo, considerando as posições através dos qual o pesquisador se situa no campo e a relação que estabelece com o mesmo. Professor-pesquisador-ex-aluno, um hibrido de papéis que, no entrecruzamento e alternância de posições, viabilizaram encontros, provocaram desencontros, fizeram parte dos frutos da pesquisa tanto quanto o fizeram todos os demais elementos.

A interdiscursividade como prática, partindo de uma concepção de linguagem como construção de sentidos, se apresenta como única possibilidade metodológica na medida em que se aposta, aqui, em um processo de pesquisa no qual pesquisador e sujeito da pesquisa estão em relação e afetam-se mutuamente no acontecimento da investigação.

A neutralidade do pesquisador é questionada como fundamento único capaz de legitimar um processo científico. A posição e o discurso do pesquisador interferem no discurso do sujeito da pesquisa. Este último pode, ele próprio, conduzir a entrevista e, com o pesquisador, construir um roteiro de investigação.

A pesquisa em tela coloca os interlocutores presentes nas imagens fotografadas nas paredes da universidade como co-participantes do processo e, em alguns casos, como disparadores de questões que colocam tanto sujeitos da pesquisa quanto o próprio pesquisador na condição de entrevistados. 
As palavras de Jobim e Souza (ano) apontam novos paradigmas e modos de pensar/fazer ciência em psicologia quando afirmam:

Dado que o conhecimento é provocado por uma pergunta, ele não pode se constituir na ausência de uma resposta. Não há resposta que não gere uma nova pergunta. Perguntas e respostas compõem a engrenagem que movimenta a construção do sentido e do conhecimento na pesquisa. (p.02)

Descartar a neutralidade do pesquisador no processo de pesquisa confere maior liberdade ao pesquisador, mas, ao mesmo tempo, exige reflexões permanentes sobre as implicações do ato de pesquisar, do ponto de vista de uma ética em pesquisa. Afirma Jobim e Souza (ano) que:

\begin{abstract}
O ato de pesquisar pode ser entendido como um acontecimento único, que se dá a partir do acontecimento singular entre o pesquisador e seu outro. Em síntese, nossa intenção é problematizar o próprio ato de pesquisar, admitindo que o acontecimento da pesquisa abarca simultaneamente um pensamento sobre o mundo e um pensamento no mundo. Ou seja, participamos de momentos diferenciados na produção do conhecimento. Por um lado, temos o pensamento que procura abarcar o mundo, por outro, o pensamento que sente a si mesmo no mundo (como parte dele). Com isso, a pesquisa pode ser vista simultaneamente como acontecimento no mundo e como um modo de participação nele. (p.05)
\end{abstract}

É preciso sobressaltar como parte constitutiva do processo de pesquisa tanto o ato de pesquisar, nos seus métodos e reflexões, quanto o momento da escritura do texto. Neste sentido, alguns aspectos precisam ser postos em análise no que concerne à questão ética e política da pesquisa em psicologia e a relação o tema deste trabalho.

As garantias quanto aos desdobramentos e aos usos e apropriações que podem ser feitos do trabalho - o que sobra objetivamente de todo o processo é o texto escrito, daí a importância a ser conferida ao modo como o pesquisador escolhe organizar as observações, escritos na forma de relatos - não existem. $O$ leitor do texto dará, ele próprio, o acabamento que melhor lhe convier, por isso a condição de inacabamento da obra e a dimensão dialógica da palavra escrita, tanto quanto da palavra falada.

Visto de outra forma, tomar contato as reverberações que o texto provoca, quando o trabalho dialoga em outros espaços, diz da maneira como o texto foi produzido e a pesquisa foi conduzida, mas também traz dados sobre o modo como a psicologia se situa frente ás temáticas e remete-nos à reflexões sobre a contribuição da psicologia e sua interlocução com as outras áreas do conhecimento. 
De um lado, o reduzido número de produções e de pesquisas sobre o tema da ação afirmativa no campo da psicologia e de temas afins, sinaliza um modo prevalecente de pensar a ciência psicológica, como restrita a questões de ordem clínica e pouco afeta a problemáticas de cunho político-social. De outro lado, as consequências e apropriações da pesquisa revelam de outra maneira, a hegemonia de uma prática clínico-assistencial no campo psicológico e a necessidade de vislumbrar possibilidades outras de análise.

Vale, como exemplo, recordar alguns dos efeitos que o trabalho de dissertação de mestrado de título: "Experiências de jovens de pré-vestibulares comunitários no convívio com a alteridade" suscitaram em alguns contextos, quando, surgem propostas, a partir do trabalho e de seus desdobramentos, de organizar grupos terapêuticos com os estudantes bolsistas de ação social com vistas a minimizar os sentimentos de baixa auto-estima e de inadequação dos estudantes em função do sofrimento psíquico causado pelo convívio em um espaço estrangeiro, em uma instituição voltada prioritariamente para um outro perfil de estudante. A indagação de um dos estudantes-bolsistas frente à proposta foi emblemática: "Porque nós temos que fazer terapia? Porque não propor grupo terapêutico com todos os estudantes da universidade?"

O acontecido suscita polêmicas e provoca reflexões importantes para o campo da ciência psicológica. As questões que se colocam são: Quais as possibilidades de contribuição da psicologia no tocante ao tema das ações afirmativas que não fiquem restritas a uma análise clínico-assistencialista? De que maneira o profissional de psicologia/pesquisador pode contribuir para pensar uma psicologia ética e afeta às questões sociais e políticas e quais as consequências políticas dos usos da ciência psicológica de modo a evitar o acirramento dos processos de exclusão sociais que visamos justamente dirimir?

Frente a estas e outras questões, espera-se que esta pesquisa aponte caminhos, suscite outras reflexões e promova, sobretudo, o debate ainda, mais do que nunca, necessário. Espera-se que este debate possa incluir a psicologia, reafirmando seu compromisso com uma sociedade mais justa e igualitária. 


\section{Referências bibliográficas}

AFONSO, M. L. M. \& RODRIGUES, C. S. Políticas de Reconhecimento e Ação Afirmativa. Revista Psicologia Política. Sociedade Brasileira - vol. 3, n 6 São Paulo: SBPP, 2003.

ALMEIDA, N. N Introdução: A Política de Ações Afirmativas na UERJ. In: Arruda, J. R. C.(orgs) Políticas de Ação Afirmativa na Universidade do Estado do Rio de Janeiro. Rio de Janeiro: UERJ, Rede Sirius, 2007.

ALMEIDA, M. A. Políticas de Ação Afirmativa e Ensino Superior: A Experiência do Curso de Graduação em Serviço Social da PUC-Rio. Orientadora: Vera Maria Ferrão Candau - dissertação apresentada como requisito parcial para obtenção do grau de mestre pelo programa de pósgraduação em educação do departamento de educação da PUC-Rio). Rio de Janeiro: PUC-Rio, 2003.

Políticas de Ação Afirmativa na Universidade Brasileira: A Experiência do curso de Graduação em Serviço Social na PUC-Rio. Social em Questão. Rio de Janeiro: PUC, Departamento de Serviço Social. v. n¹0, 2003.

ALVAREZ, J. \& PASSOS, E. Cartografar é Habitar um Território Existencial. In: Passos, Kastrup \& Escóssia (orgs) Pistas do Método da Cartografia: Pesquisa-Intervenção e Produção de Subjetividade/ Porto Alegre: Sulina, 2010.

AMADEI, S. M. N. A Execução da Política de acesso pelas cotas nos dias de hoje. In: Arruda, J. R. C.(orgs) Políticas de Ação Afirmativa na Universidade do Estado do Rio de Janeiro. Rio de Janeiro: UERJ, Rede Sirius, 2007.

ARENDT, H. O que é Política. Rio de Janeiro: Bertrand Brasil, 1998. 
BAKHTIN, M. Estética da Criação Verbal. 4ed. São Paulo: Martins fontes, 2003.

Marxismo e Filosofia da Linguagem: Problemas

Fundamentais do Método Sociológico da Linguagem. São Paulo: Hucitec, 2006.

BALL, S. J. Mercados Educacionais, Escolha e Classe Social: O Mercado como Uma Estratégia de Classe. In: Gentili, P. (orgs). Pedagogia da Exclusão: O Neoliberalismo e a Crise da Escola Pública - Petrópolis, RJ: Vozes, 1995.

BATISTA, G. Relações Raciais e Educação: Uma Análise do Programa Políticas da Cor na Educação Brasileira (PPCOR). Orientadora Vera Maria Candau. (Dissertação apresentada como requisito parcial para obtenção do grau de mestre pelo programa de pós-graduação em educação do Departamento da Educação da PUC-Rio). Rio de Janeiro: PUC-Rio, abril, 2007.

BARCELLOS, L. F. Jovens de Pré-Vestibulares Comunitários na PUCRio: Experiências e Táticas no Convívio com a Alteridade. Dissertação de mestrado. PUC-Rio, 2007.

BARROS, R. B. \& KASTRUP, V. Cartografar é acompanhar processos. In: Passos, Kastrup \& Escóssia (orgs) Pistas do Método da Cartografia: Pesquisa-Intervenção e Produção de Subjetividade/ Porto Alegre: Sulina, 2010.

BENJANIM, W. Obras Escolhidas: Magia e Técnica, Arte e Política: Ensaios sobre a Literatura e História da Cultura. São Paulo Brasiliense, 1994.

BEDRAN, P. M. Produção na Universidade: Diário de uma Micropolítica. Belo Horizonte, PUC Minas, 2003.

BELlintANI, L. P. Ação Afirmativa e os Princípios do Direito. A Questão das Cotas Raciais para Ingresso no Ensino Superior no Brasil. Editora Lúmen Juris. Rio de janeiro, 2006. 
BELISÁRIO, Aluizio. Reserva de Vagas ou Garantia de Vagas? Revista Advir n¹9/Cotas. Rio de Janeiro: ASDUERJ. Setembro, 2005.

BORGES, M. de L. Kant, Derrida e a Idéia de Universidade. In: Rampinelli, W. J. Alvim, V, Rodrigues, G. (orgs) Universidade: A Democracia Ameaçada, 2005.

BRANDÃO, C. da F. As Cotas na Universidade Pública Brasileira. Será esse o Caminho? Campinas, SP: Autores Associados, 2005.

CANDAU, V. M. \& MOREIRA, A. F. Multiculturalismo: Diferenças Culturais e Práticas Pedagógicas. Petrópolis, RJ: Vozes, 2008.

CARVALHO, J. J. Usos e Abusos da Antropologia em um Contexto de Tensão Racial: O Caso das Cotas para Negros na UnB. Horizontes Antropológicos, vol. 11. N²3 Porto Alegre, 2005.

CASTRO, L. R. de. Crianças, Jovens e Cidades: Vicissitudes da Convivência, Destinos da Cidadania. In: Castro, L. R. de (org) Subjetividade e Cidadania: Um Estudo com Crianças e Jovens em Três Cidades Brasileiras. Rio de Janeiro: 7Letras, 2001.

CERTEAU, M. de A Invenção do Cotidiano. Petrópolis: Vozes, 2004. A Cultura no Plural. Campinas, SP: Papirus, 1995.

A Invenção do Cotidiano: 2. Morar, Cozinhar. Petrópolis, RJ: Vozes, 2011.

CESAR, R. C. L. Questões Jurídicas do Sistema de Reserva de Vagas na Universidade Brasileira: Um Estudo Comparado entre UERJ, UNB e UNEB. Universidade do Estado do Rio de Janeiro. LPP. Programa Políticas da Cor na Educação Brasileira. Série Ensaios \& Pesquisas, 2004.

Políticas de Inclusão no ensino superior brasileiro: um acerto de contas e de legitimidade. In: Revista Advir n¹9/Cotas. Rio de Janeiro: ASDUERJ. Setembro, 2005. 
CHAUÍ, M. Ventos do progresso: A Universidade Administrada. In: Descaminhos da Educação Pós-68. São Paulo, Brasiliense, 1980.

Cultura e Democracia: O Discurso Competente e Outras Falas. São Paulo, Editora Cortez, 2003.

CONSELHO REGIONAL DE PSICOLOGIA. CRP-05. ano 5, n18, ago 2008

DAUSTER, T. Uma revolução silenciosa: notas sobre o ingresso de setores de baixa renda na universidade. Revista Avá. Posadas - Misiones Argentina, 2004.

DA MATTA, R. da (1992) Brasileiro, Cidadão? São Paulo. Cultura Editores Associados, 1992.

DE PAULA, M. F. C. \& LAMARRA, N. F. (orgs) Reformas e democratização da educação superior no Brasil e na América Latina. Aparecida, SP: Idéias \& Letras, 2011.

DIAS SOBRINHO, J. Educação Superior: Democratização, Acesso e Permanência com Qualidade. In: De Paula, M. F. C. \& Lamarra, N. F. (orgs) Reformas e democratização da educação superior no Brasil e na América Latina. Aparecida, SP: Idéias \& Letras, 2011.

DUARTE E RAMPINELLI, W. J. Universidade, Sociedade e Política: Algumas Considerações sobre A Relação entre Público e Privado em Tempos de Barbárie. In: Rampinelli, W. J. Alvim, V. Rodrigues, G. (orgs) Universidade: A Democracia Ameaçada. São Paulo: Xamã, 2005.

FERES JUNIOR, J. Aprendendo com o debate público sobre ação afirmativa, ou como argumentos ruins podem tornar-se bons tópicos de pesquisa. In: Paiva \& Almeida. Entre dados e fatos: ação afirmativa nas universidades públicas brasileiras. Rio de Janeiro: PUC-Rio, Pallas Ed, 2010.

FREIRE, N. A. A Experiência da Universidade do Estado do Rio de Janeiro (UERJ) na implantação de Cotas para ingresso na universidade. In: Peixoto, M. do C. de L. (org) Universidade e Democracia: Experiências e Alternativas 
para a ampliação do Acesso à Universidade Pública Brasileira. Belo Horizonte: Editora UFMG, 2004.

FRY, P. et alli (orgs). Divisões Perigosas: Políticas Raciais no Brasil Contemporâneo. Civilização Brasileira, Rio de Janeiro, 2007.

FOUCAULT, M. de Microfísica do Poder. Rio de Janeiro: Edições Graal, 1979.

FRIGOTTO, G. Os delírios da razão: crise do capital e metamorfose conceitual no campo educacional. In: Gentili, P. (orgs). Pedagogia da Exclusão: O Neoliberalismo e a Crise da Escola Pública - Petrópolis, RJ: Vozes, 1995.

GONÇALVES, L. A. O. \& Gonçalves e Silva, P. B. O Jogo das Diferenças: $O$ Multiculturalismo e seus contextos. Belo Horizonte: Autêntica, 2006.

GENTILLI, P. Adeus à Escola Pública: A Desordem Neoliberal, a Violência do Mercado e o Destino da Educação das Maiorias. In: Gentili, P. (orgs). Pedagogia da exclusão: o neoliberalismo e a crise da escola pública Petrópolis, RJ: Vozes, 1995.

JENSEN, G. Política de Cotas Raciais em Universidades Brasileiras: Entre a Legitimidade e a Eficácia. Curitiba: Juruá, 2010.

GUARTARRI, F. Caosmose: Um Novo Paradigma Estético. São Paulo: Ed. 34, 1992.

GOHN, M. da G. M. Movimentos Sociais e Educação. São Paulo: Cortez, 1992.

GOMES, N. L. Cotas para a População Negra e a Democratização da Universidade Pública. In: Peixoto, M. do C. de L. (orgs) Universidade e Democracia: Experiências e Alternativas para a Ampliação do Acesso à Universidade Pública Brasileira. Belo Horizonte: Editora UFMG, 2004. 
GOMES, A. M. et alli. Políticas de Educação Superior no Brasil: Mudanças e Continuidades. In: De Paula, M. F. C. \& Lamarra, N. F. (orgs) Reformas e Democratização da Educação Superior no Brasil e na América Latina. Aparecida, SP: Idéias \& Letras, 2011.

HASENBALG, C. A. Discriminação e Desigualdades Raciais no Brasil. Rio de Janeiro: Edições Graal, 1979.

IGREJA, R. L. O Estado Brasileiro e as Ações Afirmativas. REVISTA ADVIR n¹9/Cotas. Rio de Janeiro: ASDUERJ, setembro, 2005.

IOKOI, Z. M. G. Prefácio. In: Rampinelli, W. J. Alvim, V, Rodrigues, G. (orgs) Universidade: A Democracia Ameaçada, 2005.

JOBIM E SOUZA, S.(org) Subjetividade em Questão: A Infância como Crítica da Cultura. Rio de Janeiro: 7Letras, 2005.

Observações de Mikhail Bakhtin sobre a pistemologia das ciências humanas. Rio de Janeiro, 2000.

KAMEL, A. Não Somos Racistas: Uma Reação aos que Querem nos Transformar numa Nação Bicolor. Rio de Janeiro: Nova Fronteira, 2006.

LESSA, C. M. R. Democracia e Universidade Pública: o Desafio da Inclusão Social no Brasil. In: Peixoto, M. do C. de L. (org) Universidade e Democracia: Experiências e Alternativas para a Ampliação do Acesso à Universidade Pública Brasileira. Belo Horizonte: Editora UFMG, 2004.

Declaração Mundial sobre o Ensino Superior para O Século XXI: Visão e Ação.

LOPES, C. Cotas raciais: Por Que Sim? Rio de Janeiro: Ibase, 2005.

MATTOS, W. R. de. Inclusão Social e Igualdade Racial no Ensino Superior Baiano - Uma Experiência de Ação Afirmativa na Universidade do Estado da Bahia (Uneb). In: Bernardino, J \& Galdino, D. (orgs) Levando a Raça a Sério: Ação Afirmativa e Universidade. Rio de Janeiro: DP\&A, 2004. 
MARIZ, C. L. Fernandez, S. R. A \& BATISTA, R. Os Universitários da Favela. In: Zaluar, A. e Alvito, M. (orgs) Um Século de Favela. Rio de Janeiro: Editora FGV, 2003.

MAIO, M.C. \& SANTOS, R. V. Política de Cotas Raciais, Os "Olhos da Sociedade" e os Usos da Antropologia: O Caso do Vestibular da Universidade de Brasília. (UNB). Horizontes Antropológicos. Porto alegre, ano 11. N23, p.181-214, jan/jun 2005.

MENDONÇA, G. P. Desigualdades Raciais no Brasil: Os Desafios da Luta por Reconhecimento para o Constitucionalismo. Dissertação de mestrado, PUC-Rio. Departamento de direito. Pós-Graduação em direito, PUCRio. Rio de janeiro, junho de 2007.

MIRANDA, L. L. Subjetividade: A (Des) construção de um conceito. In: Jobim e Souza, S. (org) Subjetividade em Questão: A Infância como Crítica da Cultura. 2 ed.Rio de Janeiro: 7Letras, 2005.

PAIVA, A. R. \& ALMEIDA, L. C. Mudança no Campus: Falam os Gestores das Universidades com Ação Afirmativa. In:. Rio de Janeiro: PUC-Rio, Pallas Ed, 2010.

PAIVA, A. R. Apresentação. In: Entre Dados e Fatos: Ação Afirmativa nas Universidades Públicas Brasileiras. Rio de Janeiro: PUC-Rio, Pallas Ed, 2010.

PAIS, J. M. As múltiplas "caras" da cidadania. In: Castro, L. R. de.; Correa, J. (orgs.) Juventude Contemporânea: Perspectivas Nacionais e Internacionais. RJ: Nau Editora, 2005. (p.107-133)

PASSOS, E. \& BARROS, R. B. de. A Cartografia como Método de Pesquisa-Intervenção. In: Passos, Kastrup \& Escóssia (orgs) Pistas do Método da Cartografia: Pesquisa-Intervenção e Produção de Subjetividade/ Porto Alegre: Sulina, 2010.

PEIXOTO, M. do C. de. L. Políticas para a democratização do acesso e a inclusão social na educação superior do Brasil. In: De Paula, M. F. C. \& Lamarra, 
N. F. (orgs) Reformas e Democratização da Educação Superior no Brasil e na América Latina. Aparecida, SP: Ideias \& Letras, 2011.

PENA, S. D. J \& BORTOLINI, M. C. Pode a Genética Definir quem deve se Beneficiar das Cotas Universitárias e demais Ações Afirmativas? Estudos. av. vol.18 n. 50 São Paulo Jan./Apr. 2004.

PENIN, S. T. de S. A USP e a Ampliação do Acesso à Universidade Pública. In: Peixoto, M. do C. de L. (org) Universidade e Democracia: Experiências e Alternativas para a Ampliação do Acesso à Universidade Pública Brasileira. Belo Horizonte: Editora UFMG, 2004.

ROMÃO, J. E. Educação e Cidadania. In: Pinsky, J. Práticas de Cidadania. São Paulo, Contexto, 2004.

SANTOS, R. E. Reserva de Vagas para Negros em Universidades Públicas: Um Olhar sobre a Experiência Brasileira. In: Revista Advir n¹9/Cotas. Rio de Janeiro: ASDUERJ. Setembro, 2005.

SANTOS, F. D. R Cotas: Atos de Exclusão Substituídos por Atos de Inclusão? In: Paiva, A. R. Ação Afirmativa na Universidade: Reflexão sobre Experiências Concretas Brasil-Estados Unidos. Rio de Janeiro:Ed. PUC-Rio: Desiderata, 2004.

SÁ, M. S. M. M. Políticas de ação afirmativa: uma estratégia de sobrevivência dentro da universidade pública. In: Arruda, J. R. C.(orgs) Políticas de Ação Afirmativa na Universidade do Estado do Rio de Janeiro. Rio de Janeiro: UERJ, Rede Sirius, 2007.

SANT'ANNA, A. A. F. O Direito de Ser Diferente: Processos de Singularização com uma Aposta da Vida contra a Exclusão. In: Souza Jr, J. G. de. (et all) (orgs.) Educando para Direitos Humanos: Pautas Pedagógicas na Universidade. Porto Alegre: Síntese, 2004.

SALVADOR, A. C. Ação Afirmativa no Ensino Superior: Estudo da Política de Inserção de Alunos Pobres e Negros na PUC-Rio. Tese de Doutorado no Departamento de serviço social, set, 2008. 
SALVADOR, A. C. Ação Afirmativa na PUC-Rio: A Inserção de Alunos Pobres e Negros. Rio de Janeiro. Ed. PUC-Rio, 2011.

SPINK, M. J. P. \& MEDRADO, B. Produção de Sentidos no Cotidiano: Uma Abordagem Teórico-Metodológica para Análise das Práticas Discursivas (cap. II). In: Spink, M. J. P. (org) Práticas Discursivas e Produção de Sentidos no Cotidiano: Aproximações Teóricas e Metodológicas. São Paulo: Cortez, 1999.

SOARES, L. E. Juventude e Violência no Brasil Contemporâneo. In: Novaes, R. e Vannuci, P. (orgs). Juventude e Sociedade: Trabalho, Educação, Cultura e Participação. São Paulo: Editora Fundação Perseu Abramo, 2004.

SOUZA, D. D de. Combate ao racismo: compromissos e ações propositivas. In: Pinsky, J. Práticas de Cidadania. São Paulo, Contexto, 2004.

TAVARES, E. \& MOISÉS, R. Esta democracia?! Ou a Invenção do novo... In: Rampinelli, W. J. Alvim, V, Rodrigues, G. (orgs) Universidade: A Democracia Ameaçada, 2005.

TORRES, C. A. Estado, Privatização e Política Educacional: Elementos para uma Crítica do neoliberalismo. In: Gentili, P. (orgs). Pedagogia da Exclusão: 0 Neoliberalismo e a Crise da Escola Pública - Petrópolis. RJ: Vozes, 1995.

UNESCO/CRUB (Conselho de Reitores das Universidades Brasileiras) Conferência Mundial sobre Ensino Superior - CMES (1998: Paris, França) Tendências de Educação Superior para o Século XXI (tradução de Maria Beatriz Ribeiro de Oliveira Gonçalves) Brasília: UNESCO/CRUB, 1999.

VALENTIM, D. F. D. Políticas de Ação Afirmativa e Ensino Superior: A Experiência da UERJ na Perspectiva dos Professores da Faculdade de Direito. Orientadora: Vera Maria Candau. (dissertação de apresentada como requisito parcial para obtenção do grau de mestre pelo programa de Pós- 
graduação em educação do departamento de educação da PUC-Rio). Rio de Janeiro: PUC-Rio, junho/2005.

VIEIRA, A. L. da C. Gonçalves e Silva \& Silvério, V. R. Políticas de educação, educação como política. Observações sobre ação afirmativa como estratégia política. In: Gonçalves \& Silva, P. B. e Silvério, V. R. (orgs) Educação e Ações Afirmativas: Entre a Injustiça Simbólica e a Injustiça Econômica. Brasília. Instituto Nacional de Estudos e Pesquisas Educacionais AnísioTeixeira, 2003.

VILLARDI et alli . Perspectivas de Democratização da Educação Superior - Um Estudo do Sistema de Vagas Reservadas na UERJ. In: Arruda, J. R. C.(orgs) Políticas de Ação Afirmativa na Universidade do Estado do Rio de Janeiro. Rio de Janeiro: UERJ, Rede Sirius, 2007. 